LA IMPORTANCIA DE IMPLEMENTAR LA INVESTIGACIÓN PENAL EN CONTEXTO PARA LOS CRIMENES DE LESA HUMANIDAD PERPETRADOS EN COLOMBIA

ÁNGELA MARÍA TORRES PINEDA

UNIVERSIDAD SANTO TOMAS

FACULTAD DE DERECHO Y CIENCIAS POLÍTICAS

MAESTRÍA EN DERECHO PENAL

BOGOTÁ, D.C.

2.018 


\title{
LA IMPORTANCIA DE IMPLEMENTAR LA INVESTIGACIÓN PENAL EN CONTEXTO PARA LOS CRIMENES DE LESA HUMANIDAD PERPETRADOS EN COLOMBIA
}

\section{ÁNGELA MARÍA TORRES PINEDA}

\author{
Director de Tesis \\ Dr. Norman Lozano \\ Docente Universidad Santo Tomás
}

Trabajo de grado para optar al título de Magister en Derecho Penal

\section{UNIVERSIDAD SANTO TOMAS}

FACULTAD DE DERECHO Y CIENCIAS POLÍTICAS

MAESTRÍA EN DERECHO PENAL

$$
\text { BOGOTÁ, D.C. }
$$


Nota de aceptación 
Firma del jurado

Firma del jurado

Firma del jurado

Bogotá, D.C., 31 de diciembre de 2.018 


\section{Dedicatoria}

Dedico el presente trabajo de investigación, en primer lugar, a Dios Nuestro Señor, quien me dio la oportunidad de realizar esta maestría; en segundo lugar, a mis padres, quienes siempre creyeron en mi capacidad para poder desarrollarlo; y en tercer lugar, a mis dos hermanos, José

Alejandro y Adriana Margarita, quienes lamentablemente fallecieron durante su elaboración, y que desde el cielo, me ayudaron a culminarlo, con seriedad, constancia, responsabilidad y disciplina. 


\section{Agradecimientos}

Agradezco a los funcionarios públicos y fiscales, que prestan sus servicios profesionales en la Dirección de Análisis y Contextos y en la Dirección de Políticas Públicas de la Fiscalía General de la Nación, quienes desde el primer momento en que comencé el desarrollo del presente trabajo de investigación, estuvieron prestos a brindarme toda su colaboración, a través del suministro de la información relacionada con la metodología de investigación penal de análisis de contexto, para crímenes de lesa humanidad perpetrados en Colombia, en lo referente a doctrina, normatividad, jurisprudencia, entrevistas y ejemplos de casos investigados con dicha estrategia, con el objetivo de conocerla a fondo, para proceder a su aplicación, y de esta forma, llegar a la verdad real e histórica, identificar a los máximos responsables de los grupos subversivos, y proceder al desmantelamiento y desmovilización de los miembros de estos grupos subversivos. 


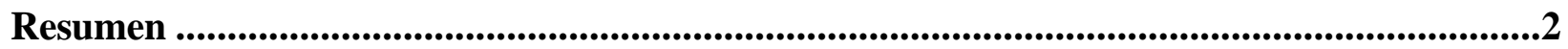

Problema de Investigación .......................................................................................................6

Pregunta de Investigación........................................................................................................................

Justificación ...................................................................................................................................................8

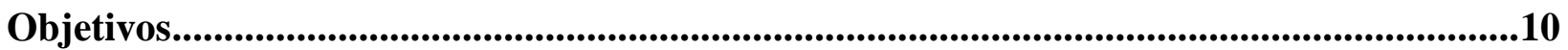

Hipótesis ..............................................................................................................................11

Diseño Metodológico ................................................................................................................................12

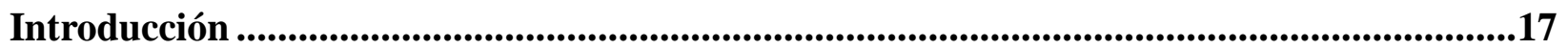

\section{CAPÍTULO 1}

La Investigación Penal de Análisis de Contexto, para los crímenes de lesa humanidad perpetrados en Colombia ........................................................................................................................20

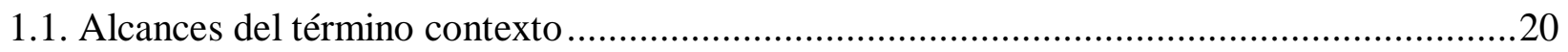

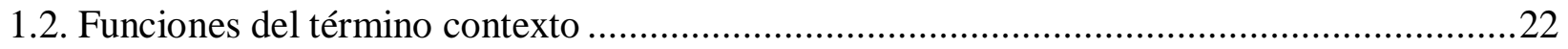

1.3. El contexto como medio y como fin en la investigación penal ...........................................24

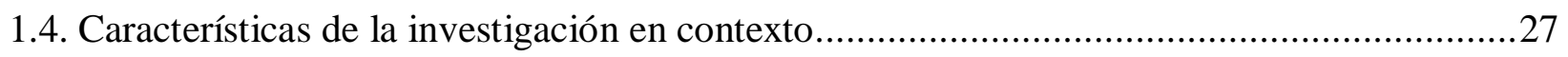

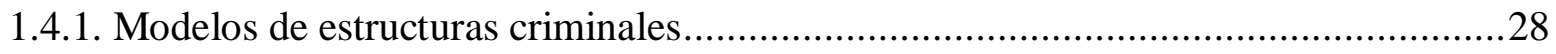

1.4.2. El funcionamiento de la estructura delictiva: planes, estrategias, móviles y patrones criminales (aspecto dinámico) ................................................................ 30

1.4.3. Las condiciones geográficas, políticas, sociales, económicas y culturales, como formas de origen y de supervivencia de las organizaciones delictivas ........................35

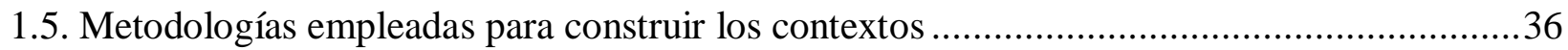

1.6. La investigación de crímenes de lesa humanidad con agentes del Estado y estructuras de

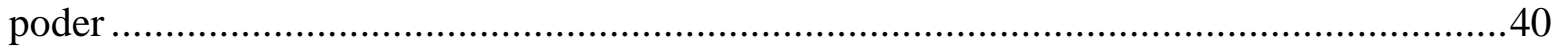

1.6.1. Justificación de las investigaciones al participar agentes del Estado ..........................41 
1.6.2. Fundamentos del Derecho Internacional y del Derecho Comparado acerca de las

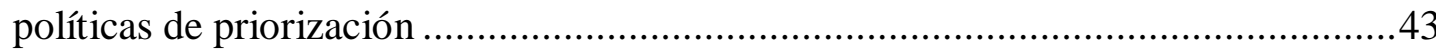

1.7. Fuentes Jurídicas de la investigación de análisis de contexto ............................................50

1.7.1. El análisis de contexto desde la Fiscalía General de la Nación...................................50

1.7.2. Políticas de priorización en la Unidad Nacional de Justicia y Paz de la Fiscalía General de

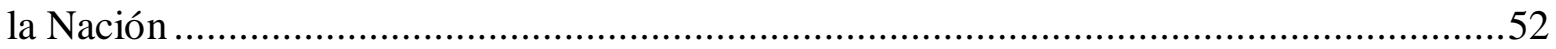

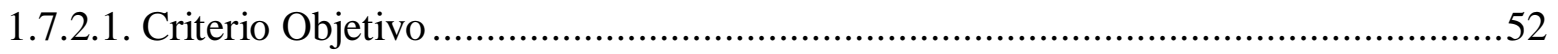

1.7.2.1.1. Memorando No. 008, Mayo 22 de 2006 .....................................................52

1.7.2.1.2. Memorando No. 73 de Octubre de 2008 .........................................................53

1.7.2.2. Conjunción de Criterios objetivo, subjetivo y complementario ...............................53

1.7.2.2.1. Circular del 16 de Septiembre de 2008 ..........................................................53

1.7.2.2.2. Memorando No. 70 de 16 de Septiembre de 2008.........................................54

1.7.2.2.3. Memorando No. 48 de 10 de Julio de 2009...................................................54

1.7.2.2.4. Memorando No. 57 de 15 de Agosto de 2008 y Memorando No. 74 de 19

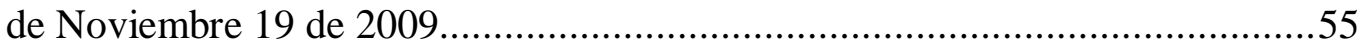

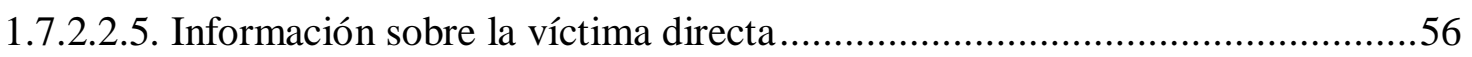

1.7.2.2.6. Memorando No. 3 de 19 de Febrero de 2010 ................................................56

1.7.3. La Directiva 001 de 2012 de la Fiscalía General de la Nación ..................................57

1.7.4. El análisis de contexto en el Acto Legislativo No. 01 de 2012 .................................62

1.7.5. La Jurisprudencia Constitucional de Justicia y Paz .................................................. 71

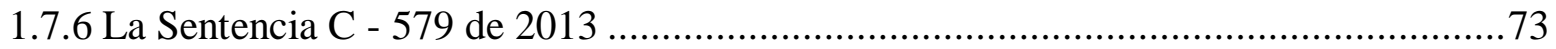

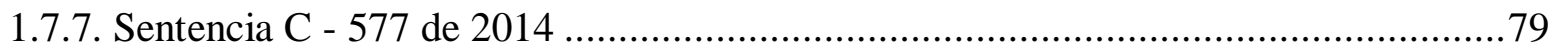

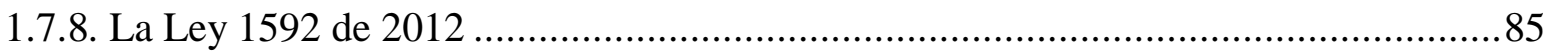

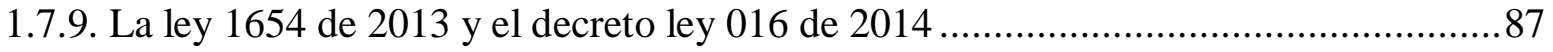

1.8. Fundamentos constitucionales de las políticas de priorización ..............................................89

1.8.1. El deber de proteger la vida, honra, bienes, derechos y libertades ............................8 89

1.8.2. El derecho a la igualdad ..........................................................................................91

1.8.3. El derecho de acceso a la administración de justicia ..................................................99

1.8.4. Ley 975 de 2005 y sus decretos reglamentarios .......................................................94

1.8.5. De la ley 1448 de 1997 a la ley 1421 de 2010 .......................................................94 
1.9. La importancia de investigar, por medio del contexto, los crímenes de lesa humanidad perpetrados en Colombia

\section{CAPÍTULO 2}

\section{Metodologías de investigación penal, con base en criterios de priorización, para crímenes de lesa humanidad desde el Derecho Internacional ..........................................................................98}

2.1. La estrategia de selección y priorización desde el derecho internacional ..........................98

2.2. La forma de construir los contextos en el derecho internacional.................................... 105

2.3. La política de priorización en los Tribunales Penales Internacionales ............................ 106

2.4. Las formas de investigación de los crímenes de lesa humanidad, en los Tribunales Penales Internacionales

2.4.1. La forma de investigación para los crímenes de lesa humanidad, en el Tribunal Penal Internacional para la antigua Yugoslavia 110

2.4.2. La forma de investigación para los crímenes de lesa humanidad, en la Corte Penal Internacional.

3.4.2.1 Focalización de investigaciones y acusaciones 116

2.4.3. La forma de investigación penal en contexto, en el Sistema Interamericano de

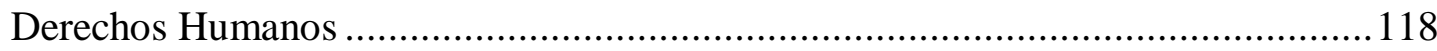

2.4.3.1. El contexto como prueba de violación de los derechos humanos .....................119

2.4.3.2. El contexto como determinante de patrones sistemáticos 121

2.4.3.3. El contexto para identificar crímenes de lesa humanidad 123

2.4.4. El análisis de contexto en la Corte Interamericana de Derechos Humanos, en casos contra el estado colombiano

2.4.4.1. La postura de la Fiscalía General de la Nación sobre el contexto, en la jurisprudencia interamericana de derechos humanos.

2.4.5. Posturas frente al contexto en los organismos internacionales 129

2.4.5.1. Tribunal ad - hoc de Núremberg. 129

2.4.5.2. Tribunales ad - hoc para la Antigua Yugoslavia y Ruanda 130

2.4.5.3. Tribunal Europeo de Derechos Humanos

2.4.5.4. Corte Interamericana de Derechos Humanos 
2.5. El delito de desplazamiento forzado, en la jurisprudencia del Tribunal Penal Internacional para la antigua Yugoslavia

2.5.1. Los desplazamientos son punibles conforme al derecho internacional consuetudinario

2.5.2. Definición de deportación, traslado forzoso y desplazamiento forzado.

136

2.5.3. El delito de desplazamiento forzado, no se limita a través de una frontera nacional 138

2.6. Consideraciones generales sobre los crímenes de lesa humanidad 139

2.6.1. Características de los crímenes de lesa humanidad 140

2.6.1.1. El Ataque 140

2.6.1.2. El carácter generalizado o sistemático 141

2.6.1.3. En contra de la población civil 143

\section{CAPÍTULO 3}

Metodologías de investigación penal, con base en criterios de priorización, para crímenes de lesa humanidad perpetrados en Colombia ..........................................................................145

3.1. La investigación penal de análisis de contexto en el derecho penal colombiano ................ 145

3.1.1. La construcción del contexto en el derecho penal y procesal penal colombiano ...... 145

3.1.2. Problemas teóricos de la investigación de análisis de contexto en el Derecho Penal Colombiano ................................................................................ 148

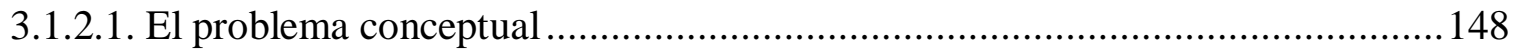

3.1.2.1.1. La diferencia entre el concepto y la concepción en filosofía y en la teoría del derecho. 148

3.1.2.1.2. Análisis de contexto, designio común, empresa criminal conjunta, modus operandi, practica, patrón y situación

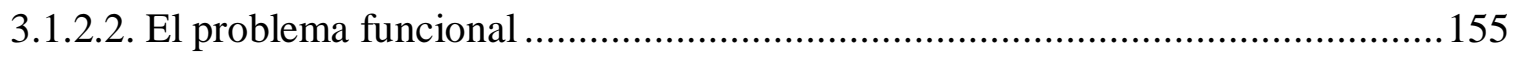

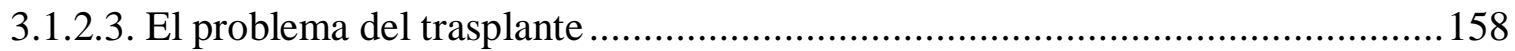

3.1.2.3.1. Trasplantes y migraciones de conceptos jurídicos ................................. 158

3.1.2.3.2. El marco de origen y el marco de recepción de la investigación en contexto 
3.2. La competencia de los órganos judiciales colombianos para acusar, condenar y sancionar crímenes de lesa humanidad 161

3.3. Características de los delitos de carácter permanente, como el delito de desplazamiento forzado por la violencia en Colombia. 166

3.3.1. Crímenes de lesa humanidad y el delito de desplazamiento forzado 167

3.3.2. Diferencia entre deportación y traslado forzoso de la población civil en la jurisprudencia del Tribunal Penal Internacional para la Antigua Yugoslavia. 168

3.4. Régimen probatorio para los crímenes de lesa humanidad perpetrados en Colombia 169

3.5. El Proceso Especial de Justicia y Paz en Colombia 174

3.6. Políticas de priorización en el Proceso Especial de Justicia y Paz en Colombia..... 176

3.7. Limitantes en las investigaciones, para los crímenes de lesa humanidad perpetrados en Colombia 180

3.8. Realidad sobre el delito de desplazamiento forzado en Colombia 183

3.8.1. La falta de una adecuación típica adecuada para el delito de desplazamiento forzado en Colombia 192

3.9. Inexistencia de elementos contextuales en los tipos penales colombianos 193 3.10. Los crímenes de lesa humanidad y las infracciones al Derecho Internacional Humanitario 195

\section{CAPÍTULO 4}

Estudio de caso y entrevistas

4.1. Escrito de acusación de la Fiscalía Local de Buenaventura de un caso de concierto para delinquir y desplazamiento forzado por la violencia agravado, dentro de los enfrentamientos entre los grupos criminales la empresa y los urabeños en dicha zona de conflicto.

4.2 Análisis criminal previo del caso, por medio de la metodología de investigación penal de análisis de contexto. 197

4.2.1 Contexto de la situación fáctica. 197

4.2.2 Criterios de priorización aplicables al caso...... 198

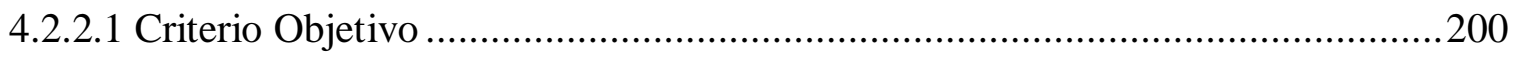

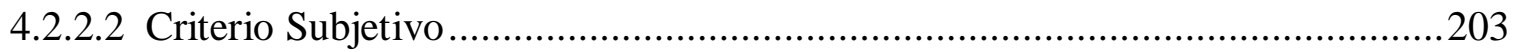

4.2.2.3. Criterio Complementario .205 
4.2.2.4 Análisis del escrito de acusación

4.2.2.5 Población, en la que se aplicó el instrumento de investigación, de entrevistas

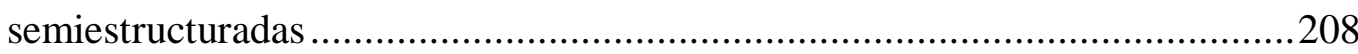

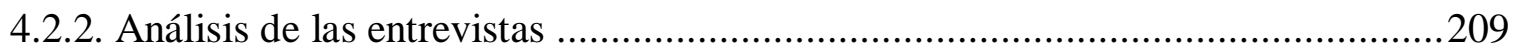

CONCLUSIONES ............................................................................................................212

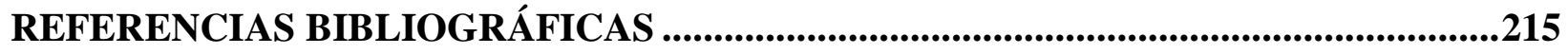

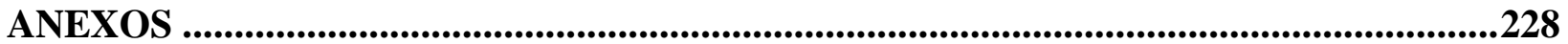




\section{Índice de Figuras}

\section{Pág.}

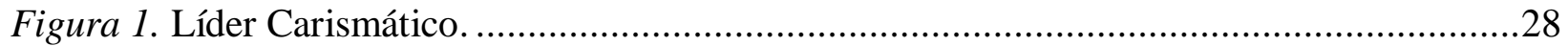

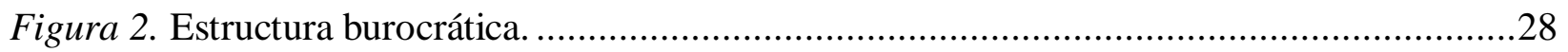

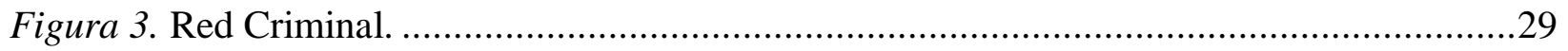

Figura 4. El Contexto Criminal. ..............................................................................................

Figura 5. Metodologías para construir los contextos................................................................

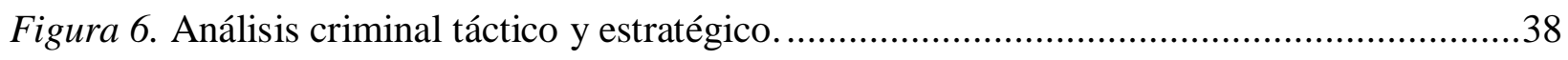

Figura 7. Fases de la construcción del contexto..........................................................................40

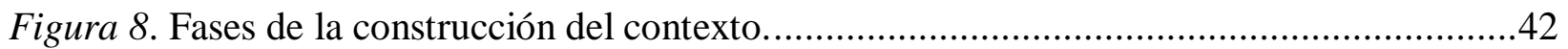




\section{Resumen}

En el primer capítulo, se realizará una breve descripción acerca del origen, significado, funciones, características y finalidades de la investigación penal de análisis de contexto, como instrumento de política criminal, y estrategia de solución a las limitaciones en el proceso de investigación, por parte de la Justicia Penal Ordinaria, en relación a los crímenes de lesa humanidad perpetrados en Colombia, con el objetivo de superar los índices de impunidad de dichas conductas criminales, desmantelar a las diversas organizaciones criminales existentes en Colombia, y lograr, los fines de la Justicia Transicional y la Justicia Restaurativa a favor de sus víctimas.

En el segundo capítulo, se darán a conocer los diversos criterios de priorización de situaciones y casos, que han sido empleados, para investigar los crímenes de lesa humanidad, desde el Derecho Internacional, y en particular por parte de los Tribunales Penales Internacionales, tales como, la Corte Penal Internacional, la Corte Interamericana de Derechos Humanos, el Tribunal Europeo de Derechos Humanos, la Convención Americana de Derechos Humanos, y los Tribunales ad hoc, dentro de los cuales, se han implementado políticas de priorización.

En el tercer capítulo, se realizará una descripción, de los criterios de priorización de situaciones y casos, que han sido empleados hasta el momento, para investigar los crímenes de lesa humanidad perpetrados en Colombia, señalando a grandes rasgos, las deficiencias dentro de dichos procesos de investigación para estas conductas, como crímenes de alto impacto nacional, con el objetivo de salvaguardar los derechos de sus víctimas, identificar a los máximos responsables de estos grupos criminales, y lograr la imputación de la responsabilidad penal consecuente de sus conductas. 
Finalmente, y con el propósito de demostrar la importancia de implementar dicha estrategia de investigación para los crímenes de lesa humanidad perpetrados en Colombia, por parte de la Dirección de Análisis y Contextos de la Fiscalía General de la Nación, en el cuarto capítulo, se presentará un estudio de un caso que fue investigado con base en dicha estrategia, sobre el delito de desplazamiento forzado por la violencia agravado, en concurso heterogéneo con el delito de concierto para delinquir agravado, realizado por parte de la Fiscalía Local de Buenaventura, y la realización y análisis, de tres entrevistas semiestructuradas, a funcionarios de la Dirección de Análisis y Contextos, y de la Dirección de Políticas Públicas, de la Fiscalía General de la Nación, y de la Corte Constitucional, que han llevado a cabo sus investigaciones por medio de dicha estrategia de política criminal.

Palabras clave: Investigación, análisis de contexto, política criminal, crímenes, lesa humanidad, impunidad, justicia transicional, justicia restaurativa, criterios de priorización, justicia penal ordinaria, impunidad, conductas criminales, justicia transicional, justicia restaurativa, criterios de priorización, mecanismos de investigación, desplazamiento forzado, victimas, máximos responsables, responsabilidad penal, derecho penal internacional, tribunales penales internacionales, la Corte Penal Internacional, la Corte Interamericana de Derechos Humanos, el Tribunal Europeo de Derechos Humanos, la Convención Americana de Derechos Humanos, Tribunales ad hoc del Derecho Penal Internacional, estudio de caso, concierto para delinquir agravado, estrategia, entrevistas semiestructuradas, Fiscalía General de la Nación, Corte Constitucional. 


\section{Summary}

In the first chapter, a brief description will be made about the origin, meaning, functions, characteristics and purposes of the criminal investigation of context analysis, as an instrument of criminal policy, and strategy of solution to the limitations in the investigation process, by part of the Ordinary Criminal Justice, in relation to the crimes against humanity perpetrated in Colombia, with the aim of overcoming the indices of impunity of said criminal conducts, and dismantling the various criminal organizations existing in Colombia, and achieving the ends of Transitional Justice and Restorative Justice in favor of its victims.

In the third chapter, the various criteria for prioritizing situations and cases that have been used to investigate crimes against humanity will be announced, from International Law, and in particular by the International Criminal Tribunals, such as, the International Criminal Court, the Inter-American Court of Human Rights, the European Court of Human Rights, the American Convention on Human Rights, and the ad hoc Tribunals of International Criminal Law, within which prioritization policies have been implemented.

In the third chapter, a description will be made of the criteria for prioritizing situations and cases, which have been used so far, to investigate the crimes against humanity perpetrated in Colombia, pointing out in broad terms, the deficiencies within said processes of investigation for these conducts, like crimes of high national impact, with the aim of safeguarding the rights of their victims, identifying the maximum responsible for these illegal groups, and entering to impute the consequent criminal responsibility of their behaviors.

Finally, and with the purpose of demonstrating the importance of implementing this research strategy in the crimes against humanity perpetrated in Colombia, by the Directorate of Analysis and Contexts of the Office of the Attorney General of the Nation, in the fourth chapter, it will be presented the study of a case that was investigated based on this strategy, on the crime of forced displacement due to aggravated violence, in heterogeneous contest with the crime of aggravated conspiracy to commit, carried out by the Local Prosecutor's Office of Buenaventura, and the realization and analysis, of three semi-structured interviews, to officials of the Analysis 
and Contexts Directorate, and of the Directorate of Public Policies, of the General Prosecutor's Office of the Nation, and of the Constitutional Court, who have carried out their investigations through said criminal policy strategy.

Keywords: Research, context analysis, criminal policy, crimes, crimes against humanity, impunity, transitional justice, restorative justice, prioritization criteria, ordinary criminal justice, impunity, criminal behavior, transitional justice, restorative justice, prioritization criteria, mechanisms of investigation, forced displacement, victims, maximum responsible, criminal responsibility, international criminal law, international criminal tribunals, the International Criminal Court, the Inter-American Court of Human Rights, the European Court of Human Rights, the American Convention on Human Rights, ad hoc Courts of International Criminal Law, case study, aggravated conspiracy, strategy, semi-structured interviews, Office of the Attorney General of the Nation, Constitutional Court. 


\section{Problema de Investigación}

La limitación por parte de la justicia penal ordinaria, en lo que respecta a un adecuado e idóneo proceso de investigación para los crímenes de lesa humanidad perpetrados en Colombia, al ser estudiados de manera aislada, es decir, caso por caso, no logra reducir eficazmente, los índices de impunidad de estas conductas, tampoco hace realidad los fines de la Justicia Transicional, ni la Justicia Restaurativa a favor de las víctimas de estos crímenes atroces, y como consecuencia de todo lo anterior, se aumenta la falta de credibilidad y de confianza por parte de nuestra administración de justicia.

Al estudiar dichos crímenes caso por caso, es decir, de manera aislada, no se logra analizar a profundidad, todo el andamiaje que conlleva la realización de estos operativos criminales, es decir, no se logra identificar todo el contexto social, político, económico, etc.., en el cual, fueron perpetrados, por lo tanto, y para dar una solución adecuada a dicha problemática, se requiere priorizar tanto las situaciones como los casos que son objeto de investigación por parte del ente acusador, debido a la basta complejidad y gravedad de dichas conductas, con la finalidad de identificar a los máximos responsables, conocer la estructura de dichas organizaciones criminales, su modus operandi, sus patrones de macroriminalidad, y proceder, al desmantelamiento y a la imputación de la responsabilidad penal consecuente, de conformidad con el daño que fuera causado a sus víctimas.

Finalmente, se requiere necesariamente, de la implementación de la investigación penal de análisis de contexto, como estrategia innovadora, y creativa, para poder realizar un investigación integral, general y holística de esta clase de conductas, para lograr construir el marco lógico en el cual, se podrían realizar otras posibles investigaciones que se encuentran implícitas dentro de dichos crímenes, a través del estudio de los patrones de macrocriminalidad utilizados por dichos grupos criminales, con el propósito de identificar y atacar de raíz, los posibles planes ilegales implícitos que existan por parte de estos grupos criminales, y fortalecer de esta manera, el sistema de administración de justicia en Colombia. 


\section{Pregunta de Investigación}

¿Se considera indispensable la aplicación de la metodología de investigación de análisis de contexto, para los crímenes de lesa humanidad perpetrados en Colombia? 


\section{Justificación}

Se requiere de la elaboración del presente trabajo de investigación, debido a que como futuros abogados penalistas, es nuestro deber conocer a profundidad las características, funciones y finalidades del nuevo sistema de investigación penal de análisis de contexto, implementado por parte de la Fiscalía General de la Nación, con el propósito de aplicar su metodología para investigar crímenes de lesa humanidad, que hayan tenido un impacto considerable en Colombia, con base en los criterios de priorización de situaciones y casos, con el objetivo de proceder a desmantelar a las organizaciones criminales perpetradoras de crímenes contra la vida, la seguridad ciudadana, la integridad personal, la libertad personal, los derechos humanos, los derechos constitucionales, los derechos fundamentales, el derecho internacional de los derechos humanos, y el derecho internacional humanitario.

Al poner en práctica dicha metodología de investigación, se estudian de forma holística e integral, los crímenes de alto impacto que han atentado durante décadas contra la institucionalidad de nuestro estado colombiano, con el propósito de estudiar a profundidad, el origen, desarrollo y funcionamiento de las empresas criminales conjuntas y de los aparatos organizados de poder, con el objetivo de que las víctimas de la violencia en nuestro país, recobren la confianza en nuestro aparato jurisdiccional, se logren la justicia restaurativa a su favor, la seguridad ciudadana y se logre conocer la verdad histórica y material de estos hechos.

La desconfianza de nuestra población civil como víctima del conflicto armado interno en Colombia, en lo que respecta a proceso de investigación para crímenes de lesa humanidad, sin obtener hasta el momento resultados favorables a su favor, no logra hacer realidad los fines de la Justicia Transicional, ni la salvaguarda de sus derechos, lo cual, conlleva falta de credibilidad en nuestro sistema judicial colombiano, al no poseer las herramientas adecuadas desde el punto de vista sustancial ni procesal, para lograr una correcta investigación y administración de justicia. 
Al proceder a investigar los hechos de forma aislada, se desestima el pensamiento garantista y protector de un Estado Social de Derecho como es el Colombiano, y de los derechos de los procesados, en el caso de que busquen acogerse a los beneficios que otorga la Ley de Justicia y Paz, para lograr su desmovilización y un posible desmantelamiento de los grupos criminales; por tal razón, se requiere que la Fiscalía General de la Nación, implemente las garantías procesales necesarias para proceder a realizar políticas de priorización de situaciones y casos, por medio del sistema de investigación penal en contexto, para estudiar a fondo una situación criminal determinada, a los grupos y a los planes criminales implícitos dentro de los operativos realizados, para llegar a la verdad material e histórica de los hechos perpetrados, resarcir los derechos vulnerados, superar los sentimientos de frustración, y los índices de impunidad de estas conductas.

Finalmente, a través de dicha estrategia de investigación, se logra combatir de forma directa, el crimen de alto impacto tanto a nivel nacional como internacional, con el objetivo de estudiarlo desde un enfoque diferente, más complejo e integral, debido a que estos hechos atroces, requieren necesariamente ser investigados de forma holística en comparación con los delitos comunes, con la finalidad de lograr los fines de la justicia transicional y la justicia restaurativa de la población civil colombiana, como víctima de la violencia en nuestro país. 


\section{Objetivos}

\section{Objetivo General}

Revelar, la importancia, de la implementación del modelo de investigación penal de análisis de contexto, para los crímenes de lesa humanidad perpetrados en Colombia.

\section{Objetivos Específicos}

- Ahondar, acerca del origen, significado, funciones, características, y utilidad de la metodología de análisis de contexto, como estrategia de investigación para los crímenes de lesa humanidad perpetrados en Colombia.

- Exponer, los mecanismos judiciales de investigación penal, con base en criterios de priorización, empleados para los crímenes de lesa humanidad, desde el ámbito del Derecho Internacional.

- Explicar, los mecanismos judiciales de investigación penal, con base en criterios de priorización, empleados para los crímenes de lesa humanidad perpetrados en Colombia

- Demostrar, el beneficio del empleo de la estrategia de la investigación en contexto, para los crímenes de lesa humanidad perpetrados en Colombia, a través de los resultados obtenidos, al aplicar las estrategias de investigación hermenéutica cualitativa, tales como, el estudio de caso y las entrevistas semiestructuradas, a funcionarios públicos que la han implementado dentro de su ejercicio profesional. 


\section{Hipótesis}

La falta de efectividad por parte de nuestro sistema penal acusatorio, en lo que respecta, a un ineficiente proceso de investigación para los crímenes de lesa humanidad perpetrados en Colombia, es la principal consecuencia, de una administración de justicia limitada, precaria, y obsoleta, la cual, ha desencadenado, desestabilización institucional, desconfianza, y falta de credibilidad en nuestro sistema de administración de justicia, debido a que al investigar estas conductas de manera aislada, es decir, caso por caso, no se logran hacer realidad los fines de la justicia transicional, se incrementan los índices de impunidad y no se logra una verdadera justicia restaurativa a favor de sus víctimas.

La justicia penal ordinaria en Colombia, hasta el momento, no ha cumplido con las expectativas, en relación a un proceso de investigación efectivo para esta clase de conductas, consideradas de extrema gravedad, las cuales, para poder ser analizadas y estudiadas a fondo, con el fin de lograr la imputación de la responsabilidad penal consecuente, requieren necesariamente de una reforma metodológica y estructural en su proceso de investigación, con el objetivo de salvaguardar los derechos de las víctimas, establecer mecanismos de reparación integral, analizar el modus operandi de estos grupos, poder identificar y judicializar a los máximos responsables, e identificar los patrones de macrocriminalidad que son utilizados, para proceder a su desmantelamiento y posible desmovilización.

Con el objetivo de superar las debilidades en el proceso de investigación, para los crímenes que atentan contra la humanidad, considerado de alto impacto a nivel social, se requiere necesariamente, de la implementación de la metodología de investigación de análisis de contexto, con el objetivo de estudiar el fenómeno de los crímenes de alto impacto perpetrados en Colombia, a través de criterios de priorización de situaciones y casos, para llegar a la verdad material e histórica, identificar a los coautores de hechos atroces, que atentan contra la estabilidad institucional y seguridad de nuestro estado colombiano, y proceder de esta forma, a imputar responsabilidad penal, con el objetivo de superar la falta de credibilidad de nuestro sistema judicial penal. 


\section{Diseño Metodológico}

La metodología de investigación, utilizada en el presente trabajo de investigación, fue la hermenéutica cualitativa, la cual, se basa principalmente en "penetrar en el proceso de interpretación e indagación, basado en la metodología de orden social”. (Romero, 2013, p.64), puesto que dicha metodología, "se reconoce como la filosofía de la interpretación que está presente en cualquier abordaje metodológico". (Romero, 2013, p.67).

Por otra parte, esta metodología se basa principalmente "en indagar la dinámica social que presenta la realidad del hombre en su permanente dinámica” (Rojano Mercado, J., 2009, p.1), esto significa lo siguiente:

una de las formas de estudiar los hechos de la realidad, es la hermenéutica, apoyada en la interpretación y comprensión de los fenómenos sociales en este caso, para dar explicación sobre aspectos que el empirismo no ha logrado dar respuesta convincente. (Rojano Mercado, 2009, p.2).

Es decir, que esta metodología se basa en "poder interpretar y comprender los hechos indagados, resaltándose por lo tanto, la interpretación y comprensión como elementos que conforman el circulo hermenéutico, que va del todo a las partes y de las partes al todo”. (Rojano Mercado, J., 2009, p.1).

Es importante destacar que dentro de esta metodología de investigación "el investigador requiere ubicarse en el apoyo de un método que le facilite, organizar o sistematizar las actividades que le permitan aproximarse a ese estudio científico de la realidad de interés" (Rojano Mercado, J., 2009, p.1), debido a que esta metodología de investigación:

se caracteriza por la proliferación de métodos, cada uno con una concepción diversa del mundo, encontrándose en este aspecto que la interpretación y comprensión de los hechos en estudio, es la columna vertebral del método conocido en la investigación cualitativa como hermenéutico. (Rojano Mercado, J., 2009, p.1) 
Esta clase de metodología, que ha sido entendida como técnica interpretativa, la cual, busca focalizar el análisis en las producciones simbólicas de los significados y en el lenguaje, por medio de los cuales, los seres humanos logran construir y comprender el mundo en el que viven.

Para Martínez, la misión de la hermenéutica es "descubrir el significado de las cosas, interpretar los mejor posible las palabras, los escritos, los textos, los gestos, y en general el comportamiento humano, pero conservando su singularidad en el contexto que forme parte". (Romero, 2013, p.68).

Hidegger, al establecer la función de la metodología hermenéutica cualitativa, para ser aplicada dentro de un proceso de investigación, manifiesta lo siguiente:

todos los intentos cognitivos para el desarrollo del conocimiento, son expresiones de interpretación. Si bien el método de interpretación es un proceso flexible, este debe seguir una serie de pasos que van del entendimiento, explicación y aplicación, a través del circulo hermenéutico. Se entiende por círculo hermenéutico al movimiento del discurso entre y desde las partes y el todo, generando una conexión de las expresiones que demarcan la esencia de la palabra. (Romero, 2013, p.68).

Gadamer, por su parte, ha definido el método hermenéutico, de la siguiente manera:

propone a la hermenéutica, como una teoría compleja, para la interpretación que debe ser abordada por todo crítico social, en el sentido que toma en cuenta al sujeto social inmerso en su contexto respectivo, y extrae de estos sus implicaciones para el significado de la comprensión. Este autor refiere que toda comunidad de vida humana, es forma de comunidad lingüística que hace lenguaje. El lenguaje precede a los hablantes y el ser que puede ser comprendido, es lenguaje, relatando la linguisticidad de la hermenéutica y es sinónimo de conocimiento del individuo en muchos ámbitos de la ciencia y en todas las esferas de experiencias con el prójimo. (Romero, 2013, p.68). 
Por otra parte, la hermenéutica de acuerdo con Vattimo, representa la filosofía del pensamiento interpretativo, la cual, se basa en determinar que la hermenéutica, "Es el arte de interpretar los textos o discursos, a partir de ella se enfatiza el contexto de lo interpretado, lo que constituye la base de la reconstrucción y de la integración". (Romero, 2013, p.68)

Por su parte, Habernas, determina que, "la hermenéutica propicia la intersubjetividad de la comprensión comunicativa, en tanto que la comprensión comunicativa dentro de la comunidad social permite la interpretación de los significados culturalmente reconocidos". (Romero, 2013, p.68)

En la presente investigación, se hizo uso de esta metodología de investigación, con el único propósito de llegar a una posible solución e interpretación del problema de investigación que fue planteado, debido a que la realidad actual que se pretende analizar, es principalmente, la limitación que se presenta, para lograr un adecuado y completo proceso de investigación, para los crímenes de lesa humanidad perpetrados en Colombia, y por tal razón, se requiere, del sistema de investigación penal de análisis de contexto, el cual, desde nuestra óptica, no ha sido lo suficientemente abordado en el derecho penal, sino desde el Derecho Penal Internacional, lo cual, imposibilita una profunda investigación para estos hechos atroces.

Al investigar crímenes de lesa humanidad perpetrados en Colombia, por parte del ente acusador, Fiscalía General de la Nación, de manera aislada, y no como un todo, posible de priorizar y de contextualizar, con el objetivo de desarticular organizaciones criminales y planes criminales que se hallen implícitos, no se logran esclarecer ni salvaguardar los derechos de las víctimas, tanto dentro como fuera del conflicto armado interno, ni hacer realidad los fines de una justicia de transición, puesto que la utilización de dicha metodología es relativamente reciente, esto significa, que las teorías que se han planteado acerca de la estrategia de investigar dichos crímenes por medio de la investigación penal en contexto, son escasas y en su gran mayoría desconocidas, para identificar sus posibles variables de interés, constituyéndose de esta forma, en un tema central de estudio. 
Dentro de la presente investigación, es de suma importancia, la aplicación de esta metodología, debido a que se logra, dar un primer acercamiento científico al problema de investigación, con la finalidad de esclarecerlo y delimitarlo; por otra parte, se busca por medio de ella, aumentar el conocimiento sobre la temática de estudio, y lograr comprender, e interpretar, la forma en que realizan los proceso de investigación para crímenes de alto impacto, por parte de los funcionarios de la Dirección de Análisis y Contextos de la Fiscalía General de la Nación, con el objetivo lograr un estudio más estructurado y pormenorizado de las situaciones y casos que lleguen a sus despachos, y llegar de esta forma, a la verdad real e histórica de la situación fáctica.

La investigación hermenéutica cualitativa, se basa en un estudio que se concentra más en la profundidad y la comprensión de un tema que en la descripción o medición, ya que le interesa sintetizar un proceso, más que analizarlo, para comprenderlo; más que limitarse solamente su medición y precisión. Dentro del desarrollo de la presente investigación acerca de la metodología de investigación penal de análisis de contexto, aplicada a los crímenes de lesa humanidad perpetrados en Colombia, se hiso uso de dicha metodología de investigación, debido a que el caso objeto de estudio, ha sido el más adecuado para realizar investigaciones exploratorias, por medio de herramientas, que sirven para estudiar y analizar, fenómenos que han sido poco estudiados, dentro del ámbito del derecho penal.

Con el apoyo de esta metodología de investigación, se logran desarrollar, conceptos, ideas y concepciones, partiendo de los datos que se poseen, es decir, se parte de una inducción, que parte de observaciones particulares, para llegar de esta forma a reglas generales, y se busca investigar tanto el contexto como las personas que lo integran como un todo, sintetizar y dar una explicación a realidades complejas, e identificar variables, que puedan llegar a ser útiles para posteriores estudios cuantitativos.

Dicha metodología es de base humanista, porque el propio instrumento que utiliza para investigar es el mismo investigador, por tal razón, se utilizaron técnicas de investigación como el estudio de un caso investigado en contexto, junto con el instrumento de las entrevistas semiestructuradas, para dar a conocer, realidades que han sido poco exploradas, en el derecho penal; además, por medio del estudio de caso, que se realizó, se buscó estudiar un fenómeno real 
como es la violencia en Colombia dentro del ámbito del contexto del conflicto armado interno, con base en diversos materiales probatorios.

A través del estudio de caso, escrito de acusación realizado por la Fiscalía Local de Buenaventura, se buscó indagar y trabajar, acerca de la estrategia de investigación penal en contexto en un caso práctico, que la misma Fiscalía Local llevó a cabo, con la finalidad de profundizar y de detallar, los conocimientos que se hayan logrado previamente a la presentación de la misma realidad, en lo que respecta al proceso de investigación penal, que se ha empleado para esta clase de crímenes, teniendo en cuenta, que las garantías que ofrece la ley de justicia y paz tanto y el sistema penal acusatorio actual, no han sido del todo suficientes, ni satisfactorias.

Por otra parte, se complementó dicho estudio, con la realización de las entrevistas semiestructuradas, las cuales, se utilizaron, debido a que dentro del presente trabajo, se deseaba obtener, una profunda y especifica información, técnica, desarrollada, en forma de dialogo coloquial, por medio de una serie de preguntas, que guiaron todo el proceso de investigación dentro del presente trabajo.

Las preguntas cambian con el desarrollo de la investigación, en un inicio tienden a ser abiertas y muy generales, posteriormente se vuelven más específicas y refinadas, con el objeto de obtener conceptos específicos, propiedades y dimensiones del objeto de estudio. Deben grabarse y complementarse con otras técnicas de recolección, como anotaciones de campo, fotografías y filmaciones. (Romero, 2013, p.70)

Finalmente, por medio de la metodología hermenéutica cualitativa, se logró la compresión total de dicha estrategia de investigación, para llevarla a la práctica, al analizar de forma holística, el fenómeno criminal de alto impacto en Colombia, con el objetivo de intervenir en la misma, por medio de la investigación en contexto, debido a que dentro de la misma, el investigador tiene la posibilidad de participar y de cooperar, junto con los investigados, para hallar soluciones adecuadas, a los vacíos presentados, dentro del proceso de investigación penal establecido por parte del sistema penal acusatorio, para estas conductas consideradas de extrema gravedad y complejidad. 


\section{Introducción}

La desconfianza por parte de nuestra sistema penal acusatorio, como sistema judicial penal colombiano, en lo que respecta a un proceso de investigación adecuado para los crímenes de lesa humanidad que han sido perpetrados en Colombia, ha generado como consecuencia, la falta de credibilidad, en lo relacionado al logro de los fines de la Justicia Transicional, la Justicia Restaurativa, y a la salvaguarda de sus derechos; esta misma situación, demuestra, que no se poseen las herramientas adecuadas desde el punto de vista sustancial ni procesal, para el logro de una correcta una administración de justicia, acorde al daño que han causado la violencia en Colombia, la cual, se ha manifestado a través de múltiples crímenes de alto impacto, que han quedado en la impunidad al no conocer la estructura de sus organizaciones criminales, su modus operandi, ni se han logrado identificar a sus máximos responsables o cabecillas.

Por lo anterior, es de vital importancia, la elaboración del presente trabajo de investigación, debido a que dentro del ejercicio profesional en el área del derecho penal, se requiere del manejo y conocimiento a profundidad de la estrategia de investigación en contexto, con el objetivo no solo de investigar crímenes de lesa humanidad, sino también, el genocidio, los crímenes de guerra y algunos delitos comunes que posean un alto nivel de gravedad y complejidad, para llegar, la verdad real e histórica de los hechos perpetrados, a favor de sus víctimas, y proceder a la judicialización de sus coautores.

La presente investigación, dentro del área del derecho penal, da a conocer lo que son y cómo deben ser empleados, los criterios de profundización de situaciones y casos, dentro de las investigaciones de crímenes de alto impacto nacional y social, para atender de forma más eficiente y efectiva, las demandas de justicia y reducir de esta manera, los altos índices de impunidad para crímenes atroces en Colombia

Para lograr lo anterior, se requiere manejar y conocer a profundidad este mecanismo de investigación, por parte del ente acusador, con el propósito de identificar, la estructura interna de las organizaciones al margen de la ley, para buscar que sus miembros se acojan a los beneficios de la ley de justicia y paz, lograr una posible desmovilización de los mismos, y salvaguardar, los 
derechos de las víctimas, los fines de la justicia transicional, la justicia restaurativa, y la tutela efectiva de sus derechos.

La lucha que ha tenido que enfrentar nuestro Gobierno Nacional, con la finalidad de lograr el desmantelamiento de los grupos al margen de la ley, hasta la fecha actual, se ha visto frustrada, debido al relajamiento de las garantías procesales, las cuales, no protegen de forma real, los bienes jurídicos, ni los derechos de las víctimas, ni los sistemas sociales imperantes en Colombia, ni a la población civil; lo anterior, ha generado, una reacción oficial desproporcionada y hasta cierto punto de vista comprensible, por parte de la población civil como víctima de la violencia, puesto que nuestras instituciones gubernamentales, no han tomado en cuenta, las garantías judiciales, para disminuir los abusos de poder, cometidos por parte de los cabecillas y coautores de estos grupos.

Al investigar los hechos que atentan contra la humanidad, que se producen dentro y fuera del contexto del conflicto armado, caso por caso, o de forma aislada, se desestima el pensamiento garantista y protector de los derechos de los procesados, los cuales, en su gran mayoría, buscan como desmovilizados, acogerse a los beneficios de la Ley de Justicia y Paz; por lo tanto, se requiere, que la Fiscalía General de la Nación, implemente las garantías procesales necesarias para realizar políticas de priorización de situaciones y casos, que al mismo tiempo, no desatiendan las restantes demandas de justicia de la población civil, por medio del sistema de investigación penal en contexto, con la finalidad de estudiar de fondo, una situación criminal determinada, identificar los planes criminales implícitos dentro de la misma, los patrones de macrocriminalidad, el modus operandi, y poder llegar así, a la verdad real de los hechos ocurridos y resarcir los derechos que han sido vulnerados.

El presente trabajo de investigación, busca investigar propiamente, los resultados obtenidos hasta la fecha, en lo que concierne a analizar a profundidad el fenómeno de los crímenes de alto impacto en Colombia, por medio de la investigación de los hechos no de manera aislada, sino, al contrario, por medio de la utilización de criterios de priorización de situaciones y casos y de la creación de contextos relacionados con la situación fáctica de todo lo ocurrido; para lo cual, se dará respuesta en el desarrollo de todo su contenido a la siguiente 
pregunta de investigación, ¿Se considera indispensable la aplicación de la metodología de investigación de análisis de contexto, para los crímenes de lesa humanidad perpetrados en Colombia?

El objetivo principal, del presente trabajo de investigación, es revelar la importancia, de la implementación del modelo de investigación penal de análisis de contexto, para los crímenes de lesa humanidad perpetrados en Colombia, y para poder lograrlo, se hará uso de la metodología hermenéutica cualitativa, dentro de la cual, por medio de la realización de un estudio de caso, el cual, fue investigado en contexto, y de la aplicación de tres entrevistas semiestructuradas, a tres funcionarios públicos que han implementado dicha estrategia de investigación, se demostrará, la importancia de estudiar los crímenes de lesa majestad, no como hechos aislados, sino como parte de todo un operativo criminal, el cual, necesita ser priorizado y contextualizado, para obtener a favor de la población civil, la seguridad ciudadana, la legitimidad, la credibilidad en nuestro aparato jurisdiccional, los fines de la justicia transicional, la justicia restaurativa, y la capacidad de atender de forma ordenada las demandas de justicia a favor de sus víctimas.

Finalmente, dentro de la presente investigación, se desarrollarán cuatro capítulos, en los cuales, se presentarán las características, particularidades, finalidades, e importancia de la investigación en contexto; los criterios de priorización de situaciones y casos para investigar crímenes de lesa humanidad perpetrados en Colombia; la forma en la cual se han utilizado las políticas de priorización desde el ámbito del Derecho Internacional para investigar crímenes de lesa humanidad; y finalmente, a través del mecanismo de la metodología de investigación hermenéutica cualitativa, con el apoyo de instrumentos de investigación el estudio de caso y las entrevistas semiestructuradas, se demostrará la importancia de la implementación de dicha estrategia para investigar crímenes de lesa humanidad perpetrados en Colombia, y que hayan ocurrido dentro y fuera del contexto del conflicto armado. 


\section{Capítulo 1}

\section{La investigación penal de análisis de contexto, para los crímenes de lesa humanidad perpetrados en Colombia}

\subsection{Alcances del término contexto}

Artículo 15. Definición de contexto. Pará efectos de la aplicación del procedimiento penal especial de justicia y paz, el contexto es el marco de referencia para la investigación y el juzgamiento de los delitos perpetrados en el marco del conflicto armado interno, en el cual se debe tener en cuenta aspectos de orden geográfico, político, económico, histórico, social y cultural. Como parte del contexto se identificará el aparato criminal vinculado con el grupo armado organizado al margen de la ley y sus redes de apoyo y financiación. (Decreto Número 3011, 2013, p.748).

De conformidad con la definición anterior, el diccionario de la Real Academia de la Lengua Española ha definido la palabra contexto como "Entorno físico o de situación, político, histórico, cultural o de cualquier otra índole, en el que se considera un hecho” (Ramelli, 2017, p.17).

En materia de Derechos Humanos, la Corte Interamericana de Derechos Humanos, ha empleado diversos términos para describir el entorno dentro del cual, se presenta, una grave vulneración de aquellos derechos, así como las modalidades de comisión de los mismos: modus operandi, práctica, patrón estructural, situación estructural, patrones de conducta, estructura de actuación, etc...

En algunos casos, la Corte Interamericana de Derechos Humanos, ha aludido a "patrones de ejecuciones arbitrarias", "sistemáticos de feminicidios", "ejecuciones extrajudiciales de niños y adolescentes", y “desapariciones forzadas”, entre otros delitos.

Dentro del fallo de la Corte Interamericana de Derechos Humanos Veliz Franco vs. Guatemala, se lograr entender el contexto, como un conjunto de factores sociales, históricos 
y políticos, que caracterizan unos hechos como parte de un patrón sistemático de violaciones de derechos humanos.

Por otra parte, los Tribunales Penales Internacionales, también han empleado, en algunas de sus jurisprudencias, la palabra "situación o contexto", por ejemplo, el Tribunal Penal para la Antigua Yugoslavia, en sentencia del 7 de mayo de 1977, en el caso Fiscal vs. Disko Tadic, hizo uso de dichos términos, de la siguiente manera:

El contexto inherente al conflicto.

Para situar en el contexto los elementos de prueba vinculados con los cargos expuestos en el escrito de acusación, y especialmente el primero de ellos (persecución), resulta importante evocar, previamente, el marco histórico, geográfico, administrativo y militar en el cual se sitúan los hechos señalados por los elementos de prueba”.(Tribunal Penal Internacional para la Ex Yugoslavia,1997,Sentencia IT-94-1-T).

Desde el ámbito de la Corte Penal Internacional, teniendo como base el Estatuto de Roma, se suele diferenciar entre situación, contexto y caso concreto. Lo anterior determina, que la Sala de Cuestiones Preliminares, en Sentencia del 17 de enero de 2006, en el asunto de Lubanga, precisó que la situación se encuentra definida por parámetros temporales, territoriales y personales, en tanto que el caso concreto, evidencia que uno o varios crímenes que son competencia de la Corte Penal Internacional, fueron cometidos por determinados delincuentes en contra de ciertas víctimas.

Lo anterior significa, que en una situación o contexto, se presenta un gran universo de conductas delictivas, ejecutadas por diversos actores armados, dentro de una determinada región, dentro de ciertos límites temporales, y de acuerdo a lo establecido dentro de un plan criminal, mientras que el caso concreto, corresponde a un hecho delictivo en específico, cuya perpetración se inscribe dentro de este gran marco factico y temporal denominado situación o contexto.

Esto quiere decir, que investigar en contexto, no solo forma parte del ámbito del derecho penal, debido a que significa ir más allá de las características del caso en concreto, ya que 
permite examinar los hechos de forma más integral, y de ésta manera, aplicar las consecuencias jurídicas más adecuadas, es decir, responsabilidad penal individual, responsabilidad internacional del Estado, procedencia de una reclamación de tierras, responsabilidad contractual y extracontractual del Estado, entre otros aspectos.

\subsection{Funciones del término contexto}

El empleo de la palabra contexto, depende de la naturaleza del ámbito donde el mismo se pretenda aplicar. Para la Corte Penal Internacional, el uso del contexto, se encuentra asociado a las violaciones masivas y sistemáticas de los derechos humanos. Es de vital importancia dentro del proceso de investigación penal, asociar un caso concreto dentro de un conjunto mayor de situaciones asociadas que configuran un patrón de macrocriminalidad o un problema de estructura de violaciones a los derechos fundamentales, con el objetivo de determinar la responsabilidad internacional del Estado en específico.

Dentro del ámbito del Derecho Penal Internacional, la Sala de Primera Instancia de la Corte Penal Internacional, en Sentencia del 14 de Marzo de 23012, en el caso de Lubanga, emplea el concepto de contexto con el fin de lograr los siguientes fines:

(i) determinar los límites geográficos y temporales del conflicto armado, en el cual se cometió el reclutamiento de menores; (ii) comprender las causas de las hostilidades; (iii) probar la existencia y la clase de conflicto armado; (iv) ayudar a establecer la responsabilidad penal del acusado; (v) acreditar el elemento psicológico del crimen de reclutamiento de menores; (vi) establecer que, si bien el condenado no reclutó directamente a los menores de edad, sí tenía el control y mando sobre la organización criminal; y (vii) demostrar la participación del acusado en el diseño y ejecución del plan criminal. (Ramelli Arteaga, 2013, p.22)

Dentro del escenario de la justicia transicional, se emplea el contexto, con el propósito de organizar las investigaciones criminales que se encuentren dispersas, relacionadas con abusos 
cometidos durante la época de una dictadura, un régimen discriminatorio, o dentro del marco de un conflicto armado interno.

De conformidad, con el informe del Relator Especial sobre la promoción de la Verdad, la Justicia, la Reparación y las Garantías de No Repetición, Pablo de Greiff (2014), se presentan, diversas modalidades de organizar investigaciones, apoyándose dentro de la visión de contexto, como son las siguientes:

- Los llamados casos "fáciles" (easiest cases). Se trata de priorizar aquellos casos que pueden ofrecer resultados en corto plazo. Su lógica consiste en buscar "las manzanas más bajas del árbol" (low-hanging fruits).

- Los casos de alto impacto (high impact cases). Consiste en enfocarse en casos que han tenido un despliegue importante en medios de comunicación.

- Las más graves violaciones (most serious violations).

- Los máximos responsables (most responsible perpetrators). En estos casos se prioriza por persona y no por tipo de delito, en especial, jefes de organizaciones delictivas.

- Los llamados "casos emblemáticos" (symbolic or paradigmatic cases). Dentro del universo de casos se priorizan algunos que muestren los patrones criminales de la organización delictiva. (De Greiff, 2014, p.21).

Dentro del ámbito de las jurisdicciones internas, como por ejemplo, la Sala Civil Especializada en Restitución de Tierras de Antioquia, Colombia, en el tema de aplicación de la Ley de Victimas, en fallo del 8 de abril de 2015, empleó la palabra contexto, para lograr los siguientes fines:

(i) probar la existencia de fenómenos de violencia regional en determinados predios; (ii) analizar la veracidad de los testimonios; (iii) examinar la existencia de buena fe exenta de culpa; y (iv) ayudar a determinar que los hechos victimizantes guarden relación con el conflicto armado interno.

Por otra parte, la jurisprudencia de Justicia y Paz en Colombia, estima que el contexto, necesariamente debe cumplir con los siguientes objetivos: 
(i) establecer los ejes transversales a partir de los cuales se pueda articular explicaciones y miradas panorámicas a un fenómeno de violencia y macro criminalidad disímil y dinámico; (ii) brindar una lectura cercana a la realidad social a través de un análisis regional en la que se muestre el comportamiento de los actores del conflicto interno; y (iii) establecer las principales fases de la evolución del conflicto, enfatizando la concurrencia simultánea de varios actores en un mismo espacio geográfico. (Tribunal Superior de Distrito Judicial, Sala de Justicia y Paz (2014, Sentencia 1100122520002014 00027).

\subsection{El contexto como medio y como fin en la investigación penal}

El contexto puede ser entendido como una actividad (investigar en contexto) - medio - o como un resultado (crear un contexto) - fin -. Al plantear el contexto como medio, se configura como un instrumento metodológico para planear o para organizar las investigaciones de crímenes de alta complejidad, en relación con violaciones graves a los derechos humanos, y al mismo tiempo, es una guía o una hoja de ruta para lograr lo siguiente:

- Determinar qué pruebas deben ser aportadas al proceso;

- Establecer las personas que deben ser llamadas a declarar;

- Orientar los interrogatorios;

- Construir diversas hipótesis investigativas;

- Asociar casos;

- Detectar individuos de una red criminal que no han sido aún judicializados;

- Cumplir un rol fundamental en la elaboración del programa metodológico, ya que no sólo se investigan hechos sino la organización criminal en sí;

- Orientar la búsqueda de nuevas evidencias y material probatorio;

- Ayudar a construir y sustentar la teoría del caso en el juicio oral;

- Aportar luces para un adecuado y eficaz empleo de instrumentos de la justicia negociada, por cuanto evita otorgar beneficios penales a individuos que se encuentren en la cúpula de la organización criminal. (Ramelli Arteaga, 2017, p.25) 
El contexto como fin, ayuda en la construcción del mismo, y esto permite analizar el valor probatorio que este mismo contexto posea dentro del proceso de investigación; de acuerdo con Carnelutti, se debe entrar a analizar el contexto como un medio de prueba, o si es un objeto de prueba, para que de esta forma se logre demostrar su existencia y determinar de qué manera esta misma existencia se pueda entrar a probar.

En relación con el contexto como medio de prueba, es importante destacar que las legislaciones internas de los Estados no lo reconocen como tal, pero de todas formas no es excluido prima facie, y con base en el principio de la libertad probatoria, algunos tribunales han reconocido su valor procesal al ser incorporado al proceso por medio de un medio de prueba tradicional, como por ejemplo por medio de un testimonio, informe de policía judicial, por medio de peritajes, etc...

A nivel del Derecho Internacional, el contexto, es introducido, mediante la figura del testigo experto, quien rinde su declaración durante el juicio oral, esto lo podemos ver, en la Sentencia No. 01/04-01/06, de la Corte Penal Internacional, sobre el caso contra Thomas Lubanga, en la cual, se determina lo siguiente:

Al momento de apreciar el testimonio de expertos, la Sala tuvo en cuenta tales como su competencia reconocida en una especialidad, los métodos empleados, y en qué medida las conclusiones presentadas por ellos coinciden con otros elementos de prueba, así como la fiabilidad general del testimonio. (Corte Penal Internacional, 2012, Sentencia 01/04-01/06)

Por otra parte, la Corte Interamericana de Derechos Humanos, en el caso familia Barrios vs. Venezuela, consideró, que no se logró demostrar de manera suficiente la existencia de un contexto específico en particular:

44. La Corte observa que la prueba aportada no contiene elementos suficientes que permitan al Tribunal pronunciarse sobre la existencia del alegado contexto de ejecuciones extrajudiciales en Venezuela ni en el estado Aragua. Por otra parte, en cuanto al alegado contexto sobre la familia Barrios, el Tribunal lo analizará oportunamente, después de haber 
considerado los hechos del caso y la prueba disponible. (Corte Interamericana de Derechos Humanos, 2011, Sentencia asunto familia Barrios vs. Venezuela).

En algunos otros casos, las consideraciones de la Corte Interamericana de Derechos Humanos han sido diferentes, en particular en el caso Veliz Franco y otros vs. Guatemala, puesto que el acápite de "hechos", expresó lo siguiente:

65. Como lo ha hecho anteriormente, la Corte recuerda que, en el ejercicio de su jurisdicción contenciosa, "ha conocido de diversos contextos históricos, sociales y políticos que permitieron situar los hechos alegados como violatorios de [derechos humanos] en el marco de las circunstancias específicas en que ocurrieron". Además, en algunos casos el contexto posibilitó la caracterización de los hechos como parte de un patrón sistemático de violaciones a los derechos humanos y/o se tomó en cuenta para la determinación de la responsabilidad internacional del Estado". (Ramelli Arteaga, 2017, p.29)

67. Con base en lo anterior, la Corte se referirá seguidamente a aspectos relativos a la prueba del contexto y, posteriormente, a la situación en Guatemala relativa a homicidios por razón de género, actos violentos contra mujeres e impunidad en la investigación, y la eventual sanción de los mismos. Sin embargo, previamente a abordar estas materias hará alusión a la invisibilidad de la violencia contra la mujer en el caso de Guatemala, pues esta situación, por una parte, permite entender la ausencia de datos estadísticos oficiales respecto de los delitos por razón de género, pero además constituye un elemento del contexto de la violencia homicida que afecta de manera específica a las víctimas mujeres. (Ramelli Arteaga, 2017, p.29)

De alguna forma se logra determinar, que "en algunos casos el contexto posibilitó la caracterización de los hechos" (medio de prueba), y en otros casos, se refiere a la "prueba de contexto" (objeto de prueba). Esto significa, que en algunos casos, es necesario demostrar la existencia de un contexto, con base en una vulneración estructural de los derechos humanos, la presencia de ataques sistemáticos contra opositores políticos, desconocimientos masivos de los 
derechos de las minorías, etc..., y una vez probados, sirven para explicar y articular casos concretos.

Una vez acreditado dentro del proceso de investigación el contexto, deberá cumplir las siguientes finalidades:

(i) ayudar a construir indicios de responsabilidad; (ii) permitir aplicar presunciones; y (iii) vincular a una persona con determinados hechos delictivos, entre otros. En tal sentido, es posible construir macrocontextos (violencia en el país, en determinados años), contextos regionales y microcontextos (conjunto de localidades). Se trata de ir más allá de la conexidad procesal, ya que se pretende superar las dificultades que comportan las rupturas procesales que conducen a fragmentar las investigaciones penales. (Ramelli Arteaga, 2017, p.30)

\subsection{Características de la investigación en contexto}

En algunos casos el contexto se ha venido empleando en los procesos por responsabilidad internacional del Estado, y por algunas jurisdicciones internas, como por ejemplo la jurisdicción de restitución de tierras, la jurisdicción de lo contencioso administrativo, entre otras, y en el derecho penal, el contexto ofrece diversas particularidades.

En el proceso de investigación por delitos complejos, las pesquisas no solamente deben examinar una conducta delictiva concreta, esto es, homicidio, violación, desplazamiento, etc..., sino además la conformación y el funcionamiento de la organización criminal, la red, o la estructura de poder que planeó y que ejecutó el delito, la forma de vinculación a la misma, y su respectivo aporte a la ejecución de todo el plan criminal que se llevó a cabo, y por otra parte, los factores políticos, sociales, económicos y culturales, que permitieron el surgimiento y supervivencia de la organización criminal. 
28

1.4.1. Modelos de estructuras criminales

Dentro de la práctica del proceso de investigación de los crímenes de lesa humanidad, se establece que las estructuras criminales, adoptan diversos modelos. De conformidad con (Ramelli Artega, 2017, p.32,) a continuación, se citan las más destacadas:

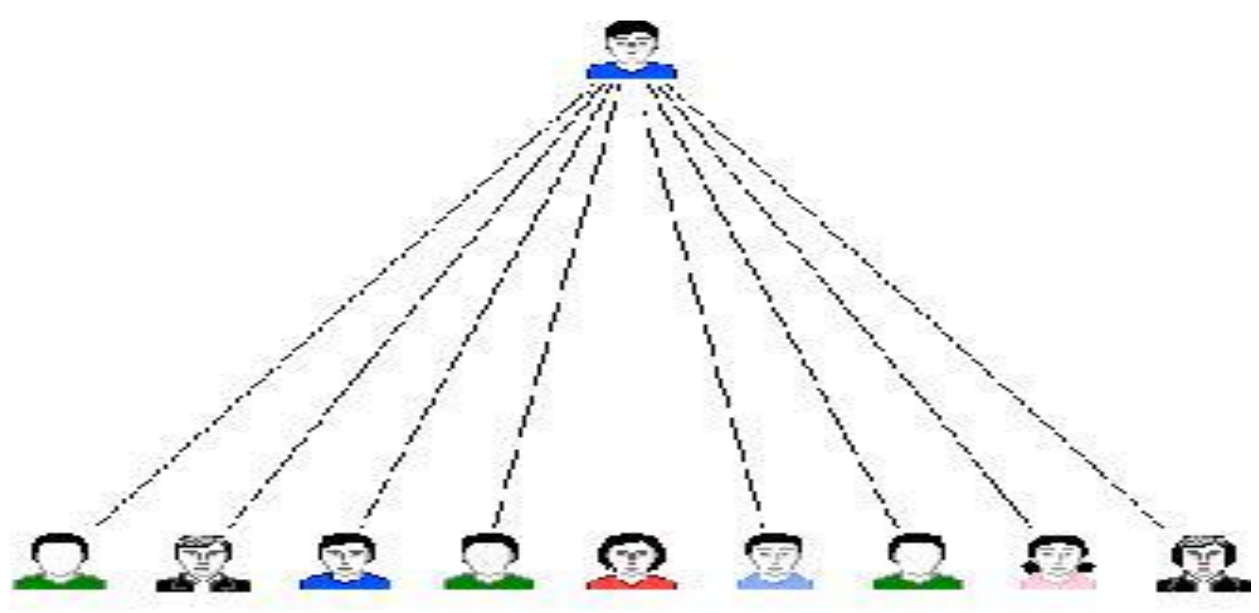

Figura 1. Líder Carismático.

Ramelli Arteaga, A., 2017, 23 de marzo, p.32.

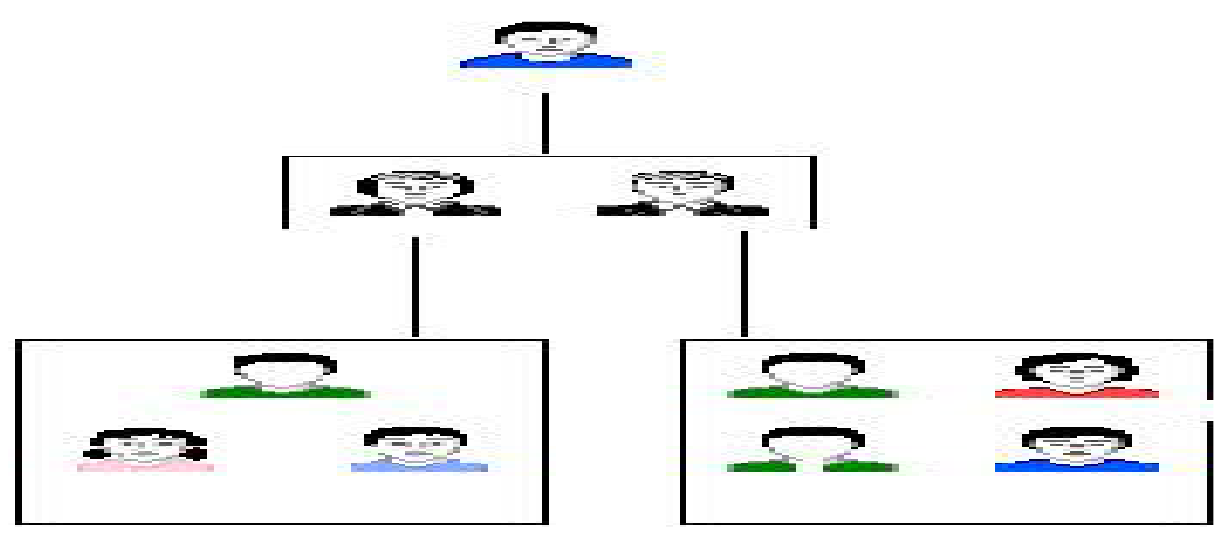

Figura 2. Estructura burocrática.

Ramelli Arteaga, A., 2017, 23 de marzo, p.32. 


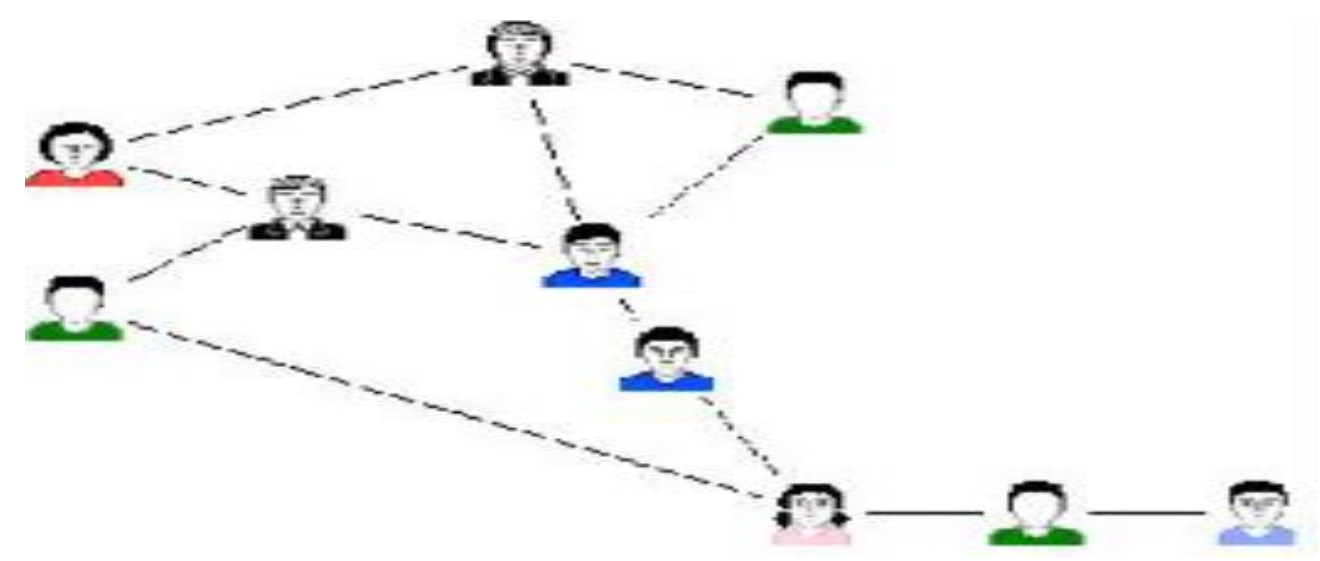

Figura 3. Red Criminal.

Ramelli Arteaga, A., 2017, 23 de marzo, p.32.

En la primera figura se puede colegir, que un líder carismático conduce directamente a las masas, o a todos los subordinados que dependan de él, mientras que el modelo burocrático está basado en jerarquías escalonadas, las cuales, se hallan sujetas a una autoridad central.

En la práctica, los Tribunales Penales Internacionales, plantean como teoría del caso, la existencia de un modelo burocrático, para que de esta forma se logren facultar las diversas imputaciones de responsabilidad penal, en tanto que los defensores, invocan una teoría del caso, según la cual, no existirían jerarquías ni roles exactos dentro de la organización, y por lo tanto, los líderes no tendrían control sobre todos los actos de sus subordinados.

Dentro de las organizaciones en forma de red, la posible identificación de los máximos responsables suele tornarse más compleja, debido a que las células conservan cierto grado de autonomía, las relaciones suelen ser horizontales y de cooperación, y además, pueden estar vinculadas por la consecución de unos objetivos comunes, y en tales escenarios, la forma de autoría y participación más adecuada sería la de la coautoría.

Una seria y verdadera investigación criminal en contexto, debe enfocarse en determinar qué clase de organización criminal, red o estructura de poder, se halla detrás de la comisión del delito, y será necesario reconstruirla para poder ubicar a cada sospechoso dentro del respectivo organigrama. 
Dentro de la estructura de la investigación criminal, los investigadores en contexto, deben estar en capacidad de responder las siguientes preguntas:

i) ¿una organización criminal con ánimo de permanencia y jerarquizada, con mando responsable y control territorial?; (ii) ¿una organización legal, que ejecuta acciones ilegales con complicidades de particulares?; (iii) ¿un entramado de redes criminales, sin jerarquías claras?; (iv) ¿se trata tan sólo de un plan criminal, con un reparto de funciones (coautoría), sin organización permanente?, o (v) se está ante una estructura de poder integrada por miembros de la fuerza pública, políticos y particulares (vgr. empresarios, financiadores, etcétera)? (Ramelli, 2017, p.33 - 33)

Cuando se trata de realizar una investigación criminal, con claros indicios de participación de la Fuerza Pública, será necesario reconstruir el correspondiente organigrama, es decir, determinar si se trata de un distrito policial, un pelotón, un batallón, una brigada, etc...

En el caso de que se trate de un partido político, es necesario determinar su composición y caracterizar sus redes de influencia, y en la caso de autoridades civiles locales, como alcaldías, gobernaciones, etc..., es importante tener claridad sobre la correspondiente estructura burocrática, y sus relaciones con otros agentes estatales, es decir, en el caso de que los alcaldes tengan la dirección de la policía judicial.

\subsubsection{El funcionamiento de la estructura delictiva: planes, estrategias, móviles y patrones criminales (aspecto dinámico)}

Las organizaciones criminales, redes o estructuras de poder, cuentan con diversos planes específicos, tales como llegar al poder político y económico de una región determinada, manejar las rentas estatales, incrementar sus finanzas, preservar unos privilegios, apropiarse de determinadas tierras, controlar la distribución de determinados productos, etc..,; y esta situación, los motiva, para cometer determinado número de delitos, como son las amenazas, los asesinatos selectivos, violencia sexual, torturas, desplazamientos, entre otros. 
Los móviles" que se hallan tras la comisión de crímenes selectivos, difieren de las motivaciones presentes en los delitos comunes, como son, la venganza, la ambición, el miedo, los celos, etc...y aparte de los móviles particulares, dichos aparatos criminales, actúan siguiendo determinados comportamientos, que son conocidos como los "patrones delictuales", que en términos conceptuales para Elster (2009), se define como "una regularidad en el comportamiento humano que debe tener dos características: (i) debe ser de "fácil reconocimiento"; y (ii) debe tener una "aparición frecuente bajo ciertas circunstancias desencadenantes". (Elster, 2009, p.52)

Por "fácil reconocimiento", se alude a que un patrón de comportamiento debe ser verificable empíricamente, en tanto que la "aparición frecuente bajo la identificación de circunstancias desencadenantes", refiere a que el patrón debe ser observable de manera recurrente dentro de un conjunto interrelacionado de condiciones que en principio son desconocidas, pero que el investigador debe determinar.

La anterior explicación, aboga, por explicaciones multicausales y no monocausales, pues no basta con identificar una sola condición o hecho generador de un fenómeno, sino que es de vital importancia identificar las condiciones necesarias y suficientes para que un patrón de comportamiento se active, por ejemplo, la proximidad de unas elecciones.

En sociología, se utiliza el concepto de patrón como "una situación en la cual los valores y los códigos de comunicación dentro de una sociedad, permiten mantener el orden y la cohesión de la misma”, y en la teoría sociológica, se determina que los patrones operan a través de estructuras sociales, políticas o económicas, que persiguen una finalidad y no a nivel de individuos aislados.

Lo anterior significa, que se deben identificar los roles sociales, tales como, (clase, etnia o raza), los roles económicos (dinero y posesión de bienes) y políticos (creencias ideológicas), de los individuos que operan de forma coordinada dentro de una determinada estructura. 
Los "patrones criminales" son objeto de estudio de una ciencia nueva llamada análisis criminal, la cual, es entendida como "un conjunto sistemático de procesos analíticos, dirigidos a promover información oportuna y pertinente a las autoridades policiales e investigativas, sobre patrones delictivos y tendencias del crimen. (Sepúlveda Scarpa, 2010, p.57).

De lo que se trata es de buscar, organizar, y analizar datos que se relaciones con los delitos, infractores, víctimas y lugares, con el objetivo de encontrar información relevante y poder de ésta manera prevenirlos y esclarecerlos.

El análisis criminal se soporta en varias ciencias y teorías de la siguiente manera:

- Criminología ambiental: estudio de los factores espaciales que pueden influir en el incremento de la actividad delictiva en un determinado territorio.(Clarke \& Eck, 2005)

- Teoría de la elección racional: según Felson y Clarke, las personas toman decisiones antes de cometer un delito, de acuerdo con una percepción de oportunidad y recompensa anticipada. (Felson, 1998)

- Teoría de los patrones: de conformidad con los trabajos de Brantingham, 1991, a partir del análisis del lugar de la comisión del delito, se pueden determinar distintas variedades de víctimas y delincuentes que lo frecuentan.

- Teoría de las actividades rutinarias: los infractores, e incluso las organizaciones criminales, realizan ciertas actividades de manera frecuente. (Brantingham, 1991).

La International Association of Crime Analysts (IACA), clasifica los patrones criminales en seis grupos, que son los siguientes:

- Series: conjunto de delitos cometidos por un mismo sujeto en contra de una o varias personas.

- Spree (ola de delitos): es un patrón que se caracteriza por una alta frecuencia de actividad delictual, de un modo casi continuo.

- Hot spot (zona de alto riesgo): se presenta cuando en un lugar o zona geográfica ocurre una cantidad inusual de delitos, perpetrados por diversos delincuentes u organizaciones 
criminales.

- Hot dot (persona de alto riesgo): una misma persona, o grupo de ellas, son victimizadas con frecuencia.

- Hot product (bien preferido): un bien es apetecido o resulta ser atractivo para ciertos delincuentes.

- Hot target (objetivo preferido): un determinado lugar es frecuentemente victimizado. (Ramelli, 2017, p. 39)

En lo que respecta a la identificación de patrones criminales, diversos especialistas proponen diferentes metodologías, como son las siguientes:

- Deductivo: mediante el empleo de diversas variables (vgr. tiempo, espacio, frecuencia, modus operandi, selección de la víctima, calidad del victimario, etc.), se encuentran características comunes entre distintos delitos.

- Enfoque por clases de delitos: se divide y organiza el universo de crímenes, en función del tipo penal.

- Identificación de patrones geográficos: consiste en crear mapas que permitan encontrar constantes entre los crímenes cometidos. (Ramelli, 29017, p.39 - 40)

La identificación de patrones macrocriminales, ofrece una complejidad mayor, de acuerdo a las siguientes razones:

- El universo de víctimas, victimarios y daños causados resulta ser muy elevado.

- Se investigan delitos cometidos a gran escala, de manera masiva o sistemática, a veces durante años, ejecutados de conformidad con un plan o política de una organización criminal (art. $7^{\circ}$. del Estatuto de Roma de la Corte Penal Internacional).

- Los perpetradores son organizaciones delictivas con diversas estructuras (vgr. jerárquica, redes o nodos, híbridas, etcétera), formas de financiamiento, modus operandi y redes de colaboradores.

- Los grupos delictivos, responsables por la comisión de crímenes de sistema, no suelen cometer una única variedad de delitos (vgr. desplazamiento forzado, lavado de activos, 
homicidios, etcétera). Lo anterior, por cuanto la ejecución del plan criminal, que se materializa en un ataque contra la población civil, comprende distintas conductas delictuales. De allí que la técnica de reagrupar delitos, tomando como base una única variable (i.e. tipo de delito), resulte insuficiente para construir un patrón de macrocriminalidad. (Ramelli, 2017, p.39 - 40)

Lo anterior permite inferir, que en materia de investigación de crímenes de lesa humanidad, no basta solamente con examinar la escena del crimen, practicar algunas pruebas forenses, interrogar a algunos testigos y sospechosos, sino que se deben analizar también los planes criminales de la organización, red o estructura de poder que los planeó y ejecutó, los móviles que perseguía y los patrones criminales que identifican a la misma organización.

Por ejemplo, en el caso de adelantar una investigación criminal en la cual, existen indicios de participación de integrantes de la fuerza pública, se debe reconstruir las cadenas de mando en el ámbito jurídico y fáctico. Desde el ámbito jurídico, se refieren a la forma como se ejerce el mando y el control sobre los subordinados y en las cadenas de mando fácticas, buscan examinar cómo funciona en realidad una determinada organización, más allá de los aspectos formales y competenciales, es decir, el rol especifico que cumple un determinado individuo dentro de la organización, sus vínculos con la clase política y el poder real que detenta.

Para poder entrar a analizar las cadenas de mando fácticas y jurídicas dentro de una organización criminal, el Tribunal Penal Internacional para la Antigua Yugoslavia, cuanta con dos clases de equipos de investigadores que son los siguientes:

- Equipo de Investigación de Liderazgo (Leadership Research Team): Analistas que examinan la información recopilada en las investigaciones y compilan informes para ser usados en juicio. Los informes tienen que ver con las estructuras de liderazgo en la ex - Yugoslavia. Sus miembros comparecen como testigos expertos en el juicio.

- Equipo de Análisis Militar (Military Analysis Team). Personas con experiencia militar que analizan asuntos estratégicos, tácticos y operativos, y de cadena de mando. (Ramelli, 2017, p.42) 


\subsubsection{Las condiciones geográficas, políticas, sociales, económicas y culturales, como} formas de origen y de supervivencia de las organizaciones delictivas

Toda organización criminal, red o estructura de poder, surge y actúa en determinadas condiciones geográficas, temporales, sociales, políticas, económicas y culturales, y el análisis de este conjunto de variables, es indispensable para comprender por qué en determinadas regiones de un país, suceden crímenes selectivos o sistemáticos.

Todo el contexto criminal, comporta todo el conjunto de factores ambientales, que explican tanto la génesis y la evolución del aparato delictivo, y por la otra, una descripción de la estructura de ésta misma organización (aspecto estático), y de su funcionamiento (aspecto dinámico), es decir, los móviles, que orientan sus actos delictivos y los patrones criminales que siguen.

Lo anterior se explica de mejor manera, en el siguiente gráfico:

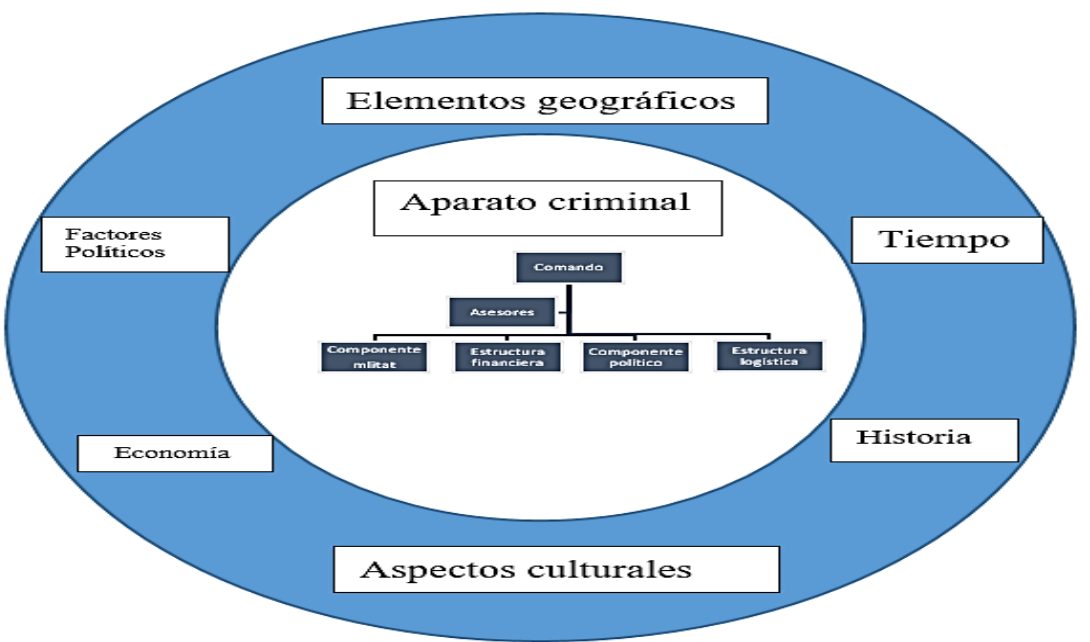

Figura 4. El Contexto Criminal. Ramelli Arteaga, A., 2017, 23 de marzo, p.46.

Dicha aproximación fue presentada por la Directiva 01 del 4 de octubre de 2012, proferida por la Fiscalía General de la Nación, de conformidad con la cual, un contexto criminal debe comprender lo siguiente: 
1) Una construcción de los elementos de orden político, económico, histórico y social de una región en la cual se han perpetrado múltiples delitos por una organización.

2) Una descripción de la organización criminal (origen, conformación, zonas de influencia, organigrama, redes de apoyo y financiación). En el caso de agentes del Estado, organigrama y competencias legales + cadenas de mando de iure.

3) Reconstrucción del funcionamiento (plan o política), los patrones delictivos (evidencian la existencia y ejecución del plan y de la relación de víctimas), cadenas de mando fácticas y jurídicas (agentes del Estado) o solo fácticas (particulares). (Ramelli, 2017, p.47).

Comparando el contexto con una película, podemos decir que los diferentes elementos de orden político, económico, histórico, y social, forman parte del escenario de los hechos criminales que fueron perpetrados; y la misma organización integral, son los integrantes del elenco de los actores que forman parte de ella y la reconstrucción y el funcionamiento de la misma, serían el guion de la misma.

\subsection{Metodologías empleadas para construir los contextos}

No existe una metodología en específico para la construcción de contextos, todo depende de los fines para los cuales vaya a emplearse, y de los Protocolos del respectivo grupo investigativo o unidad especializada para llevar a cabo dicha actividad. La investigación en contexto, logra en gran parte, combinar las técnicas de investigación tradicionales, con las técnicas de las ciencias sociales aplicadas, tal y como se muestra en el siguiente gráfico:

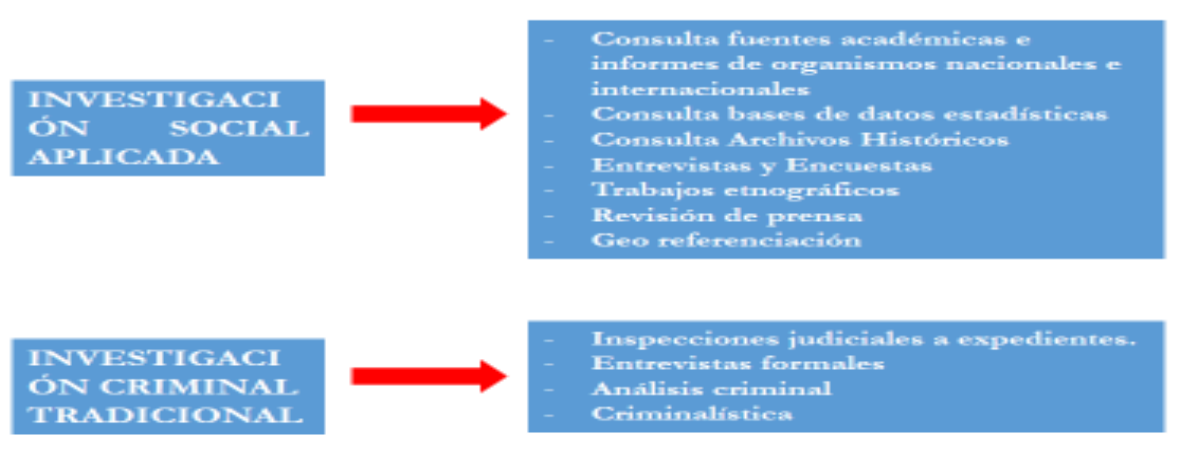


Figura 5. Metodologías para construir los contextos.

Ramelli Arteaga, A., 2017, 23 de marzo, p.48.

Para proceder a la elaboración de contextos para investigar crímenes de lesa humanidad, perpetrados de forma masiva y sistemática, y para la investigación de asesinatos selectivos, se debe diseñar un método integrado por las siguientes fases:

\section{A. Selección y delimitación de una situación focalizada}

El cual, posee diversas estrategias.

- Método inductivo: Se debe seleccionar un caso emblemático, y a partir de allí, reconstruir los planes macro-criminales de la organización.

- Método deductivo: Partiendo de la construcción de un macro-contexto de una organización delictiva, ir vinculando al mismo un número elevado de delitos, mediante la identificación de patrones.

- Método regional: Se trata de delimitar una determinada región, seleccionar los hechos delictivos más graves cometidos allí, identificar las organizaciones armadas que operan en la zona, analizar su estructura y funcionamiento, y finalmente, centrarse en identificar a los máximos responsables. (Ramelli, 2017, p.49)

\section{B. Categorización y agrupación de casos.}

El cual, se realiza empleando fuentes judiciales, tales como testimonios, sentencias, peritazgos, etc..., y fuentes extrajudiciales, tales como, informes de ONG, informes de relatores de la Naciones Unidas, estudios especializados, etc..., con el objetivo de categorizar y reagrupar los casos.

Para lograr lo anterior, se deben elaborar tablas con diversas variables, como por ejemplo, delito, victima, victimario, tiempo, lugar y modus operandi, todo lo anterior, se constituye en elementos probatorios que deben ser incorporados al respectivo proceso judicial. 


\section{Establecimiento de correlaciones entre variables y construcción de productos de análisis criminal y pruebas sociales.}

Por medio de la aplicación de técnicas criminales táctico y estratégico, metodologías de las ciencias sociales (métodos cualitativos y cuantitativos), y análisis militar (análisis de estrategias, documentos militares, manuales de operaciones, cadenas de mando fácticas y jurídicas, etc...), se cruzan variables y se elaboran productos de análisis criminal, como por ejemplo, análisis de redes, estadísticas, cuadros, georreferenciación, minería de datos, perfiles criminales, etc...y a la vez las "pruebas sociales", como por ejemplo las líneas de tiempo, cartografía social, entrevistas no judiciales, etc...

La anterior explicación, la podemos evidenciar más claramente en el siguiente gráfico:
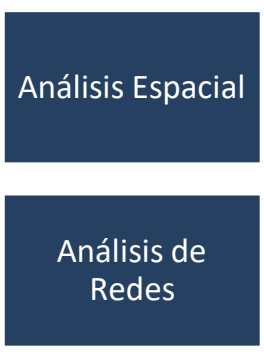
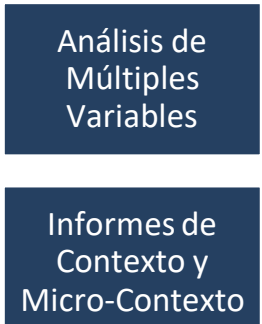

Análisis de

Discurso
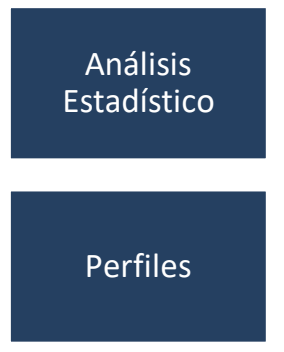

Minería de

Datos
Gestión de

información

Protocolos de

Investigación

Figura 6. Análisis criminal táctico y estratégico. Ramelli Arteaga, A., 2017, 23 de marzo, p.46

D. Incorporación al proceso de investigación del análisis criminal y del informe de contexto

El grupo de analistas ya sea que actúen como testigos expertos, peritos, o mediante los informes de policía judicial, deben incorporar al proceso los respectivos productos de análisis criminal, y el informe de contexto.

En relación con el informe de contexto, se deben explicar los siguientes aspectos: 
(i) las fuentes primarias y secundarias sobre el cual se soporta; (ii) las metodologías empleadas para recolección y procesamiento de datos; (iii) las variables usadas y los cruces realizados entre ellas; (iv) la articulación del trabajo con la teoría del caso; (v) la participación del acusado dentro del contexto construido; y (vi) unas conclusiones. En pocas palabras, la calidad de un contexto se mide por aspectos tales como: (i) el número de fuentes consultadas; (ii) la calidad de la información; (iii) la autenticidad y la veracidad de las fuentes; y (iv) la seriedad en el tratamiento de los datos. (Ramelli, 2017, p.55)

Todas las fuentes secundarias, deben ser sometidas obligatoriamente al filtro de un "Protocolo de registro y crítica de las fuentes de información", en el cual, se deben examinar los siguientes aspectos:

(i) confiabilidad de la fuente (se refiere a la autoridad, la objetividad y el propósito de la organización o autor y de la editorial o medio de publicación con respecto al objeto de estudio. Es preciso triangular, comparar y verificar la información con otras fuentes o documentos disponibles para identificar con mayor certeza los elementos de este criterio) y (ii) validez del contenido de la fuente: (se refiere a la relevancia, la pertinencia, la audiencia y la forma como se presenta la información. La eficacia en virtud del objeto de estudio será el elemento determinante en este criterio). (Ramelli, 2017, p.55)

La construcción de un contexto, es fácilmente comparable con la construcción de una fábrica, y esto lo podemos evidenciar en el siguiente gráfico: 


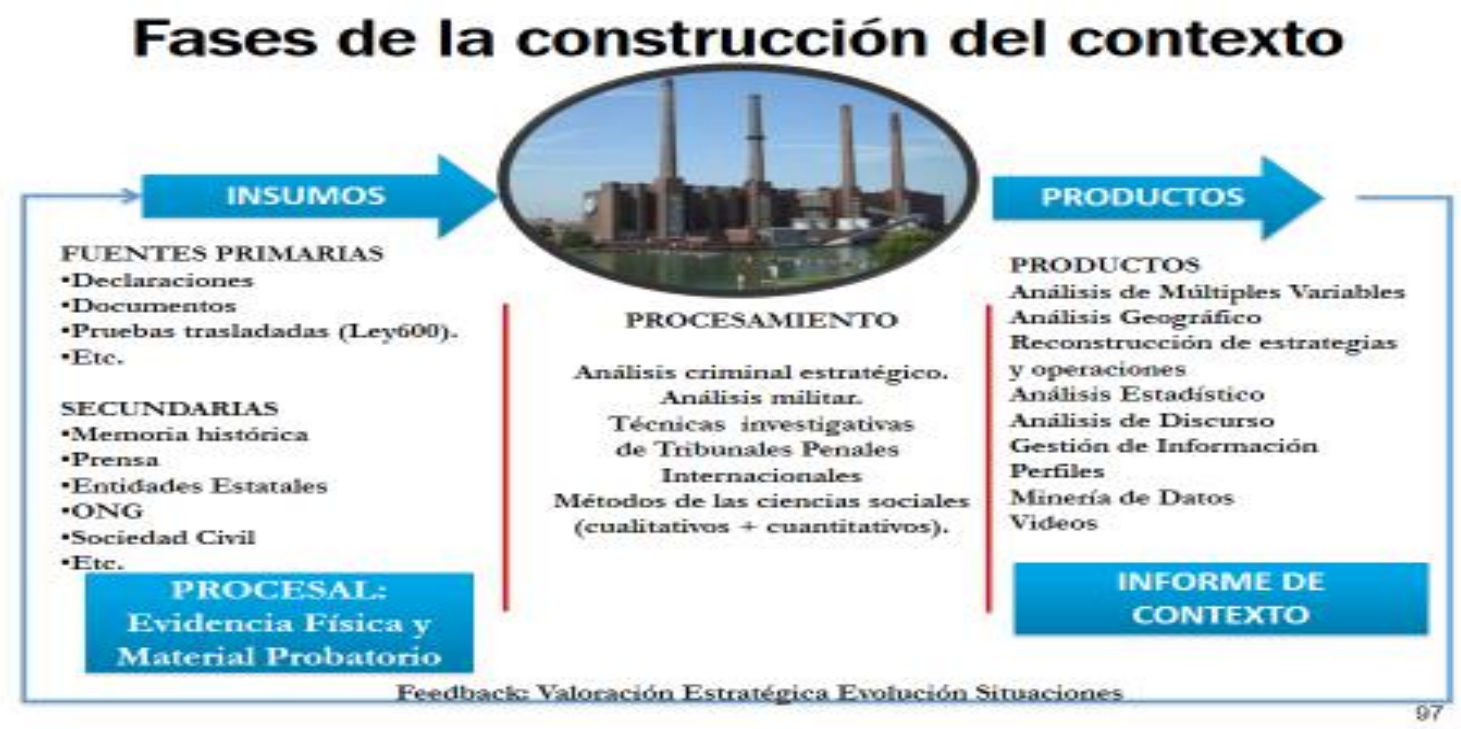

Figura 7. Fases de la construcción del contexto.

Ramelli Arteaga, A., 2017, 23 de marzo, p.56

\section{E. Carácter dinámico de la construcción de los contextos dentro del análisis criminal.}

Los contextos que se construyen dentro del análisis de los fenómenos criminales, no suelen ser productos finales o completamente terminados, debido a que nuevas informaciones y también nuevas conductas delictivas alientan y retroalimentan constantemente los contextos que han sido construidos, por parte de los analistas criminales que se hayan encargado de la construcción de esos mismos contextos.

\subsection{La investigación de crímenes de lesa humanidad con agentes del Estado y estructuras de poder}

Por medio de la realización de una investigación forense y criminalística exhaustiva y adecuada, junto con una investigación de naturaleza criminal adelantada en contexto, la cual, conlleva implícitamente un carácter interdisciplinario y el examen de organizaciones criminales, redes o estructuras de poder, se conduce a identificar y a sancionar a los máximos responsables de dichas organizaciones, es decir, a sus autores materiales e intelectuales, responsables de un crimen de lesa humanidad, sistemático y generalizado. 
Los resultados de dicha investigación, serian a grandes rasgos los siguientes:

(i) ayudaría a resolver otros casos directamente asociados con el crimen, tales como los actos de amenazas, de encubrimiento, entre otros; (ii) develaría la existencia y el funcionamiento de una organización criminal, red o estructura de poder; y (iii) en términos de satisfacción del derecho individual y colectivo a la verdad, se contaría con un relato histórico mucho más completo de lo sucedido.

\subsubsection{Justificación de las investigaciones al participar agentes del Estado}

La metodología de análisis de contexto, surge de la necesidad de comprender hechos y fenómenos de violencia de manera integral, y de ésta forma, judicializar a los autores materiales, a los determinadores, y a los máximos responsables de dichas estructuras criminales, tanto para crímenes de sistema de carácter nacional, como de carácter internacional. Por otra parte, el análisis de contexto, permite brindar a las víctimas explicaciones, más completas, profundas y detalladas sobre la forma en la cual, fueron perpetrados los hechos que se investigan, y de ésta manera dicha estrategia se convierte en un instrumento de memoria histórica, relevante dentro del proceso de investigación.

A nivel del derecho penal internacional, es relevante la utilización de la investigación de análisis de contexto, debido a que se tienen en cuenta, los elementos constitutivos de los crímenes de genocidio, de lesa humanidad, y de guerra, ya que los mismos son cometidos de forma masiva y sistemática, y sin la aplicación de una investigación en contexto, es prácticamente imposible investigar esta forma de criminalidad.

Dentro del ámbito interno de los Estados, el tener la posibilidad de acoger esta forma de investigación penal para crímenes de lesa humanidad, implica un cambio de paradigma para investigar dichas conductas, desde el ámbito del Derecho Penal: 


\begin{tabular}{|c|c|}
\hline Modelo tradicional de investigación & Investigación criminal en contexto \\
\hline Se investiga "caso a caso", de forma desarticulada. & $\begin{array}{l}\text { Asociación de casos a partir de patrones criminales } \\
\text { que permiten delimitar situaciones. }\end{array}$ \\
\hline $\begin{array}{l}\text { Se focalizan las investigaciones por la calidad de } \\
\text { víctima (vgr. sindicalista, defensor de derechos } \\
\text { humanos, miembro de un partido político) o por tipo de } \\
\text { delito (vgr. homicidio, secuestro, lavado de activos, } \\
\text { narcotráfico). }\end{array}$ & $\begin{array}{ll} & \text { Se focaliza combinando múltiples variables: } \\
\text { - } & \text { Organización criminal } \\
\text { - } & \text { Calidad de la víctima } \\
\text { - } & \text { Región } \\
\text { - } & \text { Modalidad delictiva } \\
\text { - } & \text { Factores temporales }\end{array}$ \\
\hline $\begin{array}{l}\text { La investigación se concentra en la conducta delictiva } \\
\text { y el autor de la misma }\end{array}$ & $\begin{array}{ll}\text { La investigación se enfoca en: } \\
\text { Estructura y funcionamiento de la organización } \\
\text { criminal } \\
\text { - } & \text { Hecho delictivo } \\
\text { - } & \text { Autor material y máximos responsables }\end{array}$ \\
\hline $\begin{array}{l}\text { Las ciencias sociales son consideradas, en el mejor de } \\
\text { los casos "ciencias auxiliares" del derecho. }\end{array}$ & $\begin{array}{l}\text { Permite un "diálogo" entre el derecho penal, las } \\
\text { ciencias forenses y las metodologías de las ciencias } \\
\text { sociales (vgr. historia, ciencia política, geografía, } \\
\text { antropología, sociología, etc.) y las ciencias } \\
\text { exactas (estadística, matemáticas, etc.). }\end{array}$ \\
\hline $\begin{array}{l}\text { Apta para investigar delitos cometidos por individuos } \\
\text { aislados (vgr. violencia intrafamiliar, accidentes de } \\
\text { tránsito, etcétera) }\end{array}$ & $\begin{array}{l}\text { Permite investigar casos complejos: crímenes de } \\
\text { sistema (genocidio, crímenes de lesa humanidad y } \\
\text { de guerra) y delitos selectivos. }\end{array}$ \\
\hline $\begin{array}{l}\text { Las investigaciones no se organizan de conformidad } \\
\text { con una gran estrategia investigativa. }\end{array}$ & $\begin{array}{l}\text { Las investigaciones se organizan con miras a la } \\
\text { consecución de unos fines estratégicos de política } \\
\text { criminal (vgr. evitar el resurgimiento del } \\
\text { paramilitarismo) }\end{array}$ \\
\hline $\begin{array}{l}\text { En el corto plazo, en el mejor de los escenarios, se } \\
\text { resuelven muchos casos individuales (vgr. numerosas } \\
\text { capturas de ejecutores materiales) }\end{array}$ & $\begin{array}{l}\text { Si bien a corto plazo no se ejecutan numerosas } \\
\text { detenciones, en el largo plazo se desarticula la } \\
\text { organización criminal y se llega a los máximos } \\
\text { responsables. }\end{array}$ \\
\hline
\end{tabular}

Figura 8. Fases de la construcción del contexto.

Ramelli Arteaga, A., 2017, 23 de marzo, pp.16- 17.

El grafico anterior, permite demostrar, que la investigación en contexto, surge de la necesidad de investigar crímenes de una alta complejidad, bien sean crímenes selectivos o de lesa humanidad, de forma completamente diferente a como se investigan los delitos comunes; lo anterior, con el objetivo, de identificar la organización criminal, la red, o la estructura de poder que haya sido responsable de la educación de dichos crímenes, y por esta misma vía, individualizar el conjunto de autores materiales e intelectuales que participaron en la planeación y ejecución de dichos crímenes. 


\subsubsection{Fundamentos del Derecho Internacional y del Derecho Comparado acerca de las políticas de priorización}

La técnica de priorización de casos, se ajusta a los estándares internacionales de protección de los derechos humanos y del derecho internacional humanitario y se inspira de acuerdo al funcionamiento de los tribunales penales internacionales, aunque por su naturaleza y su razón de ser, la actividad de aquéllos implica, un proceso de selección de casos y encuentra referentes en el derecho comparado.

En relación con la priorización de casos frente a los estándares internacionales de protección de los derechos humanos y del derecho internacional humanitario, se ha determinado que la técnica de priorización, se ajusta a los textos de la Convención Americana de Derechos Humanos y al Pacto Internacional de Derechos Civiles y Políticos, instrumentos internacionales que hacen parte del bloque de constitucionalidad; de igual forma, la priorización, se encuentra conforme a la jurisprudencia, que ha sido elaborada por la Corte Interamericana de Derechos Humanos, la cual, según la Corte Constitucional, constituye un "criterio relevante de interpretación”. (Colombia, Fiscalía General de la Nación, 2012, Directiva 0001, p.110)

En lo que respecta a la Convención Americana de Derechos Humanos, la misma, contiene dos clases de obligaciones convencionales en materia de administración de justicia estatal; por un lado, la obligación de garantía de los derechos, establecida en el artículo $1^{\circ}$. de dicha Convención Americana, y por el otro, el derecho a la protección judicial, contenida en el artículo 25 de la misma Convención Americana.

La obligación general de garantía, impone una obligación adicional y autónoma de cumplimiento, la cual deriva en obligaciones de investigación y de sanción, cuando existe la violación de un derecho contemplado en la Convención Americana de Derechos Humanos.

Por ejemplo en el caso Velásquez Rodríguez, la Corte Interamericana de Derechos Humanos, se refirió a la obligación de investigación derivada de la misma Convención 
Americana, por cualquier violación a un derecho reconocido en la misma, y en este caso en conexión al artículo 25 de protección judicial, dicha sentencia determina lo siguiente:

(...) El Estado está en el deber jurídico de prevenir razonablemente, las violaciones de los derechos humanos, de investigar seriamente con los medios a su alcance las violaciones que se hayan cometido dentro del ámbito de su jurisdicción a fin de identificar a los responsables, de imponerles las sanciones pertinentes y de asegurar a la víctima una adecuada reparación. (Colombia, Fiscalía General de la Nación, 2012, Directiva 0001, p.111)

De acuerdo al texto anterior, la Corte ha venido desarrollando la noción de impunidad, en relación con la negación de acceso a la justicia prohibida por el artículo 25 y la obligación general de prevención y de investigación establecida en el artículo 10.

En el caso Maritza Urrutia vs. Guatemala, la Corte Interamericana, formuló una noción de impunidad, contraria a lo establecido por la Convención Americana de Derechos Humanos, de la siguiente manera:

(...) la impunidad es la falta, en conjunto, de investigación, persecución, captura, enjuiciamiento y condena de los responsables de las violaciones de los derechos protegidos por la Convención Americana y que el Estado tiene la obligación de combatir tal situación por todos los medios legales disponibles. (...) (Colombia, Fiscalía General de la Nación, 2012, Directiva 0001, p.111)

La misma noción anterior, fue reiterada en el Caso de las masacres de Ituango, Almonacid, Arellano y otros, en la Masacre de Mapiripán y Comunidad Moiwana vs. Surinam, y es un concepto de impunidad que le concede un amplio margen al Estado.

Esa misma definición que fuera adoptada por la Corte Interamericana de Derechos Humanos, hace que la falta de investigación y de sanción de algunos casos particulares, no constituya un acto ilícito internacional, y menos aún, si se trata de la priorización de una 
investigación penal sobre otra; únicamente, lo que es prohibido es la ausencia general de la investigación y de sanción penal.

Por tal razón, la jurisprudencia que existe sobre el tema, determina que la obligación de la investigación y de la sanción penal, se ha visto truncada por la inactividad del Estado en los casos de violaciones dolosas del derecho a la vida y del derecho a la integridad personal, por otra parte, y teniendo en cuenta que la Corte, puede ordenar una investigación penal de lo ocurrido como reparación a las víctimas cuando ha encontrado una violación a la Convención, esto sólo ha ocurrido en casos de inactividad absoluta por parte del Estado, o en casos de fallas manifiestas en el procedimiento interno.

Hasta el momento ningún razonamiento de la Corte Interamericana de Derechos Humanos, indica que la priorización intencional de casos, favoreciendo la investigación de unos sobre otros con base en criterios objetivos, pueda resultar en una violación de la Convención Americana sobre Derechos Humanos.

La Corte Interamericana, favorece el tratamiento diferenciado en la investigación de los casos dependiendo de su complejidad y en el mismo sentido en que apunta una política de priorización enfocada en la investigación de los contextos macro criminales, en los cuales, se cometieron delitos sistemáticos, la Corte exige una investigación especial de contexto para los delitos más graves cometidos contra la Convención Americana de Derechos Humanos.

Dentro del sistema interamericano, ha habido una larga tradición de rechazo frente a la impunidad generada por las leyes de amnistía latinoamericanas en el siglo XX, a pesar de que las leyes de amnistía sean totalmente distintas a un sistema de priorización de casos, y la jurisprudencia del tema, es útil para determinar los límites a la discrecionalidad del Estado en el ejercicio de la acción penal.

Por ejemplo, el caso Barrios Altos, se basaba en una ley de "auto amnistía" promulgada por el Estado peruano, por medio de la cual, se exoneraba de cualquier responsabilidad a los involucrados en violaciones a los derechos humanos entre 1980 y 1995, en el caso de unos 
miembros de la división de inteligencia militar del ejército peruano, acusados de cometer una masacre en noviembre de 1991, debido a que estaban siendo procesados por la justicia ordinaria, sin embargo, se expidió la ley de amnistía que impidió la continuidad de su juicio.

Para este caso, la Corte Interamericana de Derechos Humanos consideró lo siguiente:

(...) son inadmisibles las disipaciones de amnistía, las disposiciones de prescripción y el establecimiento de excluyentes de responsabilidad que pretendan impedir la investigación y sanción de los responsables de las violaciones graves de los derechos humanos tales como la tortura, las ejecuciones sumarias, extralegales arbitrarias y las desapariciones forzadas, todas ellas prohibidas por contravenir derechos inderogables reconocidos por el Derecho Internacional de los Derechos Humanos. (...) (Colombia, Fiscalía General de la Nación, 2012, Directiva 0001, p.113).

Así mismo la obligación de investigar y de sancionar, como parte de la obligación general de proveer un recurso efectivo fue desatada en el caso de Almonacid Arellano y otros vs. Chile, donde se estudiaba el asesinato de Luis Alfredo Almonacid por parte del régimen de Augusto Pinochet, el cual había sido objeto de una posterior ley de amnistía.

En este caso, la Corte Interamericana de Derechos Humanos, se refirió a la obligación desprendida del artículo $1^{\circ}$, en los siguientes términos:

(...) la obligación conforme al derecho internacional de enjuiciar, si se les declara culpables, castigar a los perpetradores de determinados crímenes internacionales, entre los que se cuentan los crímenes de lesa humanidad, se desprende de la obligación de garantía consagrada en el artículo 1.1. de la Convención Americana. (...). (Colombia, Fiscalía General de la Nación, 2012, Directiva 0001, p.114).

La conclusión de la Corte Interamericana de Derechos Humanos, tiene un contexto y un alcance muy específico, que es el siguiente: 
(...) Por las consideraciones anteriores, la Corte estima que los Estados no pueden sustraerse del deber de investigar, determinar y sancionar a los responsables de los crímenes de lesa humanidad aplicando leyes de amnistía u otro tipo de normativa interna. Consecuentemente, los crímenes de lesa humanidad son delitos por los que no se pude conceder amnistía (...). (Colombia, Fiscalía General de la Nación, 2012, Directiva 0001, p.114).

Por su parte el Comité del Pacto Internacional de Derechos Civiles y Políticos, ha sostenido un razonamiento similar en relación con las amnistías, esto lo podemos ver en el caso de Rodríguez vs. Uruguay, donde se había sometido al peticionario a tratos crueles, inhumanos y degradantes y después se había exonerado de responsabilidad mediante una amnistía legal a los responsables, el Comité determinó lo siguiente:

(...) el Comité reafirma su posición bajo la cual las amnistías por violaciones masivas de derechos humanos (...) son incompatibles con las obligaciones de un Estado parte bajo el Pacto. El Comité nota con gran preocupación que la adopción de esta ley efectivamente excluye en un número de casos la posibilidad de investigar abusos de derechos humanos y por lo tanto previene que el Estado parte cumpla con su responsabilidad de proveer un remedio efectivo a las víctimas de dichos abusos (...). (Colombia, Fiscalía General de la Nación, 2012, Directiva 0001, p.115)

Los reiterados pronunciamientos acerca de la legalidad de las amnistías, confirma la deferencia que se le concede al Estado en relación con su obligación de investigación y sanción que está establecida dentro de los artículos 1 y 25 de la Convención Americana de Derechos Humanos. Todas las leyes sobre amnistías que han sido objetadas por la Convención Americana de Derechos Humanos, reunían dos características notorias: 1. La exoneración total de la responsabilidad penal; 2. Por actos que constituyeran violaciones graves de derecho internacional.

Nunca es una obligación del Estado, la investigación exhaustiva, sino la investigación de las violaciones más graves, por las personas más responsables. Hasta la fecha, en ningún caso, se 
ha encontrado que un Estado sea responsable, por la ausencia de investigación penal en delitos que no constituyen violaciones graves o masivas de derechos humanos y eso es bastante sorprendente, teniendo en cuenta la noción de impunidad que sostiene la Corte Interamericana de Derechos Humanos.

De todo lo anterior, se puede analizar, que la jurisprudencia en materia de derechos humanos tiene dos limitaciones generales a la priorización de casos, la primera limitación implica un esfuerzo general de investigación, es decir, que el Estado no puede descuidar de manera general sus procedimientos judiciales y esto incluye las inactividades fiscales absolutas y estructurales.

La segunda limitación, obliga al Estado a investigar violaciones graves de derechos humanos, lo cual incluye, la comisión de delitos internacionales, y en estos casos, no se puede optar por algo distinto a la investigación y a la sanción; lo anterior implica, que una priorización objetiva de casos que comprendan las violaciones graves de derechos humanos, no riñe con las obligaciones internacionales del Estado en los instrumentos de derechos humanos.

En lo que se refiere al Derecho Internacional Humanitario, es preciso señalar que en el ámbito convencional, abarca a los cuatro Convenios de Ginebra de 1949 y a sus Protocolos Adicionales de 1977. Para los conflictos armados internacionales existe un deber convencional de enjuiciamiento o entrega, de las personas que han cometido infracciones graves a los Convenios de Ginebra y esta obligación está consagrada en el artículo 49 (2) del I Convenio de Ginebra, el artículo 50 (2) del II Convenio de Ginebra, el artículo 129 (2) III Convenio de Ginebra y el artículo 146 (2) del IV Convenio de Ginebra de la siguiente forma:

(...) cada una de las Partes Contratantes tendrá la obligación de buscar a las personas acusadas de haber cometido, u ordenado cometer, una cualquiera de las infracciones graves, y deberá hacerlas comparecer ante los propios tribunales, sea cual fuere su nacionalidad. Podrá también, si lo prefiere, y según las disposiciones previstas en la propia legislación, entregarlas para que sean juzgadas por otra Parte Contratante interesada, si ésta 
ha formulado contra ellas cargos suficientes (...). (Colombia, Fiscalía General de la Nación, 2012, Directiva 0001, p.116)

Este texto anterior, no se encuentra incluido dentro del Protocolo II, por lo tanto, no existe una fuente convencional para la obligación de investigación y de enjuiciamiento de los autores de violaciones graves al derecho internacional humanitario, en el contexto de los conflictos armados no internacionales.

No obstante el Tribunal Penal Internacional para la Antigua Yugoslavia, en el enjuiciando del caso Tadic, consideró que el régimen de infracciones del derecho internacional humanitario se estaba materializando en el derecho consuetudinario, aplicable a los conflictos armados no internacionales.

El estudio del derecho internacional consuetudinario promovido por el Comité Internacional de la Cruz Roja, considera que dentro de la cristalización del régimen de infracciones graves para los conflictos armados no internacionales, existe un deber general, mas no una obligación de investigación. Inclusive, en el caso de existir una obligación de investigación en situaciones de infracciones graves al derecho intencional humanitario en los conflictos armados no internacionales, aquélla obligación no implica la imposición de una sanción y se satisface con la asunción de la investigación por parte de un fiscal u otra autoridad competente, así esta decida archivarla por falta de méritos.

De la misma forma, la obligación de investigación y de enjuiciamiento de los autores de violaciones del derecho internacional humanitario en el contexto de los conflictos armados no internacionales, prohíbe la promulgación de amnistías generales y absolutas, pero permite los procesos de justicia transicional donde existe una exoneración parcial de responsabilidad.

En el caso de los instrumentos de derechos humanos, el derecho internacional humanitario, permite la priorización de casos siempre y cuando las infracciones graves al mismo, no queden impunes. 
Dichas infracciones, están consagradas en cada Convenio de Ginebra, pero se limitan al homicidio preterintencional, a la tortura o a los tratos inhumanos, incluidos los llamados experimentos biológicos, el hecho de causar deliberadamente grandes sufrimientos o de atentar gravemente contra la integridad física o la salud y la destrucción y la aprobación de bienes, no justificadas por necesidades militares y efectuadas a gran escala ilícita y arbitrariamente.

Esta limitación se establece para los conflictos armados internacionales, pero se discute para los conflictos armados domésticos, y aún en los casos aplicables, la asunción de la investigación por parte del ente competente, así no sea priorizada, es suficiente para cumplir con la obligación internacional, sin necesidad de producir una sanción o condena.

Lo anterior significa, que la priorización de casos, no contradice los estándares internacionales de protección de los derechos humanos ni el derecho internacional humanitario.

\subsection{Fuentes Jurídicas de la investigación de análisis de contexto}

Las fuentes jurídicas que fundamentan la investigación en contexto, son las siguientes:

i) La Directiva No. 01 de 2012 del Fiscal General de la Nación; 2) el Acto Legislativo No. 1 de 2012; 3) la jurisprudencia constitucional de Justicia y Paz; y 5) la ley de facultades extraordinarias 1654 de 2013 y el Decreto Ley 016 de 2014. (Barbosa \& Bernal, 2015, p.139)

\subsubsection{El análisis de contexto desde la Fiscalía General de la Nación}

La Fiscalía General de la Nación y más propiamente la Dirección de Análisis y Contextos, ha proferido una serie de actos administrativos, por medio de los cuales se ha configurado el análisis jurídico del "análisis de contexto".

Dicha construcción se inicia por medio de la Directiva No. 01 del 4 de octubre de 2012, por medio de la cual se adoptan "unos criterios de priorización de situaciones y casos, y se crea 
un nuevo sistema de investigación penal y de gestión", y se definen, las bases conceptuales e instrumentales que describen la figura del contexto.

Posteriormente, fueron dictados otros actos destinados a adecuar la estructura y la organización de la Fiscalía, al servicio de los objetivos y criterios trazados por medio de la misma Directiva, como ejemplo de ello, tenemos la Resolución No. 1810 de octubre de 2012, por medio de la cual se creó "La Unidad de Análisis y Contextos", y la Resolución No. 1811 de octubre de 2012, que creó y reglamentó "el Comité de Priorización de Situaciones y Casos en la Fiscalía General de la Nación”.

Además, la Resolución No. 01 del 15 de enero de 2013, la cual ordenó “a la Unidad de Fiscalía Delegada ante la Corte Suprema de Justicia y las Unidades Nacionales, la presentación de planes de acción para la gestión de los criterios de priorización e implementación del nuevo sistema de investigación" y la Resolución No. 02 del 25 de junio de 2013, que ordenó "a las Direcciones Seccionales de Fiscalías, la presentación de planes de acción para la gestión de los criterios de priorización e implementación del nuevo sistema de investigación”.

A la vez, se crearon instrumentos de implementación del sistema de investigación penal que fuera concebido y así lo podemos apreciar en el "Instructivo para la elaboración de los Planes de Acción por parte de Las Unidades Nacionales de Fiscalías y de la Unidad de Fiscalía Delegada ante la Corte Suprema de Justicia", así como en el "Instructivo para la elaboración de los Planes de Acción por parte de las Direcciones Seccionales de Fiscalías".

De la misma forma, se expidió el Acuerdo No. 02 de enero de 2013, como "Reglamento Interno del Comité de Priorización de Situaciones y Casos".

De lo anterior, se logra colegir como elementos esenciales, que estructuran la metodología del "análisis de contexto" concebida por la Fiscalía, su definición como política criminal, su justificación en la eficacia de la función pública que cumple la misma entidad, y en la racionalización de los recursos escasos con que cuenta, para lograr las finalidades constitucionales atribuidas, y su concreción a partir de ciertos ingredientes metodológicos de la investigación penal. 


\subsubsection{Políticas de priorización en la Unidad Nacional de Justicia y Paz de la Fiscalía}

\section{General de la Nación}

La Unidad Nacional de Justicia y Paz, por medio de Memorandos y de Circulares hace referencia expresa a la priorización de delitos y de víctimas, como una estrategia para adelantar investigaciones en el marco del proceso especial de justicia y paz, recogiendo los criterios objetivo y subjetivo, y los cuales, han sido utilizado por la comunidad internacional en el proceso de la justicia transicional.

\subsubsection{Criterio Objetivo}

Los Memorandos número 008 de 22 de mayo de 2006 y 73 de Octubre 7 de 2008, demuestran la intención de la Jefatura de la Unidad Nacional de Justicia y Paz, de priorizar delitos en las investigaciones que se siguen en los procesos de la Ley 975 de 2005.

\subsection{Memorando No. 008, Mayo 22 de 2006}

Este documento está dirigido a Fiscales Delegados ante el Tribunal de la Unidad Nacional de Fiscalías para la Justicia y la Paz, y dispone como directriz la "priorización de actividades" y en cuanto a la revisión de procesos, establece una clasificación de acuerdo a los siguientes criterios:

- Delitos graves especialmente masacres, apoderamiento de tierras, desplazamiento forzado, desaparición forzada, secuestro, homicidio, reclutamiento de menores, delitos de género, atentados contra indígenas, y menores.

- Utilización ilegal de uniformes e insignias; fabricación, porte y tráfico de armas y municiones y concierto para delinquir.

- Otros delitos. (Forer \& López, 2011, P. 242)

De conformidad con ese Memorando, es claro que la Unidad de Justicia y paz, ha adoptado por un sistema de investigación jerarquizado en el cual no hay camino para la 
impunidad, porque no se dejan de investigar conductas, pero lo que sí se establece, es un orden específico para el efecto atendido el criterio de "delitos graves", como lo indica dicha disposición.

\subsection{Memorando No. 73 de Octubre de 2008}

En esta disposición, se dispone la "Recepción de registros de hechos atribuibles a grupos armados organizados al margen de la ley y otros relacionados con violencia sexual y delitos conexos".

\subsubsection{Conjunción de Criterios objetivo, subjetivo y complementario}

La Unidad Nacional de Justicia y Paz de la Fiscalía General de la Nación, ha mezclado en varios memorandos y circulares el criterio objetivo, subjetivo y complementario.

\subsection{Circular del 16 de Septiembre de 2008}

Es la más clara disposición sobre el tema de la priorización, ya que menciona la "Estrategia para dinamizar el proceso" y tuvo como destinatarios a cada uno de los Fiscales Delgados ante el Tribunal que conforman la Unidad de Justicia y Paz.

Dentro de los propósitos y motivaciones del documento en mención y de acuerdo a Forer y López Díaz (2011), citamos los siguientes:

impulsar el procedimiento para arribar en el menor tiempo posible a la fase judicial ante los Magistrados de Justicia y Paz, en particular a las audiencias de formulación de Imputación en casos priorizados y, por ende, lograr las primeras sentencias. (Forer \& López, 2011, P. 243)

Entre las recomendaciones más importantes y destacadas de dicha disposición, se citan las siguientes: 
(...) es imprescindible retomar la estrategia de priorizar los casos de mayor relevancia atribuible a una organización ilegal tales como masacres, desplazamiento forzado; desaparición forzada; secuestro; homicidio en periodistas; sindicalistas; miembros de la UP, indígenas, defensores de DDHH, integrantes de ONG y servidores públicos; reclutamiento de menores, delitos de género, apoderamiento de tierras, especialmente aquellos cometidos a partir de noviembre de 2002, para agruparlos por tipo penal y su relación con los comandantes de bloque o frentes y ejecutores materiales del hecho.

Dentro de esta circular se prioriza, teniendo en cuenta el criterio objetivo y el criterio subjetivo, pues no solamente se enlistan los delitos que se debe investigar en primer lugar, tales como el homicidio, el reclutamiento y los delitos relativos al género sino, que también se tiene en cuenta la calidad de las víctimas.

Igualmente, dentro de la misma disposición, se alude a una diferenciación entre los comandantes de bloque o frente y ejecutores materiales del hecho, aunque no se clarifica si hay lugar a priorizar la investigación según el rango, de tal manera que se mantiene la tendencia de la estrategia en el sentido de jerarquizar la investigación únicamente por conducta punible.

\subsection{Memorando No. 70 de 16 de Septiembre de 2008}

Dentro de éste documento, se ordenan disposiciones especiales para atender a las víctimas de un delito particular, como en el caso de la desaparición forzada.

\subsection{Memorando No. 48 de 10 de Julio de 2009}

Dentro de este Memorando de la Unidad Nacional de Fiscalías para la Justicia y la Paz, se trata el tema de la "Transmisión de versiones a salas remotas de víctimas de versiones libres a extraditados", y se determina lo siguiente:

"En las versiones libres debe abordarse la CONFESIÓN de los siguientes hechos: 
- De conocimiento del sistema interamericano (Corte o Comisión)

- De posible competencia de la Corte Penal Internacional

- Hechos graves de acuerdo al fenómeno delictivo: desaparición forzada, desplazamiento forzado, reclutamiento ilícito y violencia sexual entre otros.

- Hechos graves en atención a la calidad de la víctima: conductas realizadas contra sindicalistas, periodistas, miembros de la unión patriótica, indígenas, afrodescendientes y menores entre otros". (Forer \& López, 2011, P. 244)

Desde esta directriz, la Unidad privilegia orden jerárquico la investigación de crímenes con transcendencia en organismos internacionales, del Sistema Interamericano de Derechos Humanos y del Sistema Penal Internacional, para que finalmente se le otorgue una gran relevancia a la víctima.

\subsection{Memorando No. 57 de 15 de Agosto de 2008 y Memorando No. 74 de 19 de} Noviembre 19 de 2009

Dentro de estas directrices de la Unidad Nacional de Fiscalías para la Justicia y Paz, se realiza la priorización por la calidad o por la importancia de la víctima.

El Memorando No. 57, trata acerca de las "sesiones especiales para abordar el tema de reclutamiento ilegal de menores“, al respecto y de conformidad con Forer y López Díaz (2011), se dispone lo siguiente:

En directrices trazadas por la Jefatura de Unidad a partir del año 2006, se ha insistido en la imperiosa necesidad de documentar los hechos atribuibles a Grupos Organizados al Margen de la Ley, especialmente el reclutamiento de menores, violencia sexual, hechos cuyas víctimas ostentaban la calidad de sindicalistas, periodistas, Defensores de Derechos Humanos, entre otros. (Forer \& López, 2011, P. 244)

Por otra parte, el Memorando No. 74, que especifica las "directrices para la recepción de declaraciones o entrevista como estrategia de documentación de hechos atribuibles a GAOML", 
determina la necesidad de orientar la investigación, durante procedimientos como las entrevistas y las declaraciones, hacia algunos delitos en particular teniendo en cuenta la calidad de la víctima.

\subsection{Información sobre la víctima directa}

“(...) Calidad: Especificar si la víctima ostentaba un rol especial por el cual era conocido en la comunidad (...)"

En este apartado, se evidencia un interés por indagar acerca de ciertas víctimas, con el objetivo de que la investigación se incline hacia los delitos derivados de la afectación de aquellas.

\subsection{Memorando No. 3 de 19 de Febrero de 2010}

En este documento se ordena remitir a la Jefatura de la Unidad de Justicia y Paz, una enorme cantidad de datos sobre menores reclutados ilícitamente a los grupos armados ilegales.

De lo anterior se puede afirmar, que son pocas las Directrices por medio de las cuales, la Unidad de Justicia y Paz, dispone expresamente de alguna estrategia de priorización para crímenes de alto impacto.

Pero las mismas, pueden ser complementadas con otras que contienen criterios para diferenciar y ordenar la investigación según la calidad de la víctima o por medio de la importancia en algunos delitos en particular, que sean delitos comunes pero que tengan características de crímenes internacionales, la cuales tienen efecto dentro de las conductas punibles que se vaya a investigar. 


\subsubsection{La Directiva 001 de 2012 de la Fiscalía General de la Nación}

El análisis de contexto planteado por la Directiva 001 de 2012 de la Fiscalía General de la Nación, se determina como elemento de política criminal, el cual se caracteriza por los siguientes elementos:

- Es una opción de política criminal que procura racionalizar la gestión de sus recursos en procura de incrementar la eficacia de su actuación.

- Es un marco para el análisis del crimen desde la interdisciplinariedad como aproximación epistemológica.

- El ingrediente de priorización es un instrumento que se presenta a la vez como política, criterio, fin y técnica de gestión de la investigación penal, con límites y prohibiciones. (Barbosa \& Bernal, 2015, p.144)

Es política, por ser un sistema de directrices y orientaciones encaminadas a introducir un cambio en la manera de cumplir con las obligaciones constitucionales y legales de la Fiscalía General de la Nación, que maximice el uso de la información y los recursos a su cargo. Se considera criterio, en el sentido de ser un parámetro lógico que sirve para focalizar la acción investigativa de la Fiscalía General de la Nación hacia determinadas situaciones y casos.

Es decir, que dicha estrategia de investigación, es considerada como un fin, por medio del cual, se busca asegurar un mayor impacto y un mejor aprovechamiento de los recursos administrativos y logísticos, para alcanzar la seguridad ciudadana y el combate más efectivo de la criminalidad organizada, el conocimiento del contexto del conflicto armado, la reducción de la impunidad y la atención de las exigencias de la sociedad civil de estudiar el crimen en su contexto, y desarticular a los grupos que vulneran gravemente los derechos humanos.

Por otra parte, el análisis de contexto desde la Directiva 001 de 2012 de la Fiscalía General de la Nación, es considerada una técnica de gestión de la investigación penal, en cuanto que por medio ella se establece "un orden de atención entre reclamos ciudadanos de justicia equivalentes", para garantizar el goce del derecho fundamental de acceso a la administración de 
justicia, sin que ello implique la extinción de la acción penal en relación con los asuntos no priorizados o la renuncia al deber de investigar y sancionar las conductas delictivas.

- Es pauta de análisis y herramienta para la Fiscalía al servicio de su función constitucional de investigar y determinar las circunstancias de tiempo, modo y lugar en que ocurrieron los hechos criminales, así como para identificar los patrones y los planes criminales.

- A falta de distinción expresa, se aplica tanto para la investigación penal de los delitos priorizados en Justicia Transicional como en Justicia Ordinaria, y responder a la categoría de crímenes de sistema o macro crímenes. (Barbosa \& Bernal, 2015, p.145)

La Directiva 01 de 2012 del 04 de octubre de 2012, es la norma, "por medio de la cual, se adoptan unos criterios de priorización de situaciones y casos, y se crea un nuevo sistema de investigación penal y de gestión de aquéllos en la Fiscalía General de la Nación”, y es de vital importancia, y por tal razón, es importante dar a conocer algunas definiciones relevantes que fueran implementadas por esta directiva.

De conformidad con la directiva, el concepto de Análisis Criminal, se determina de la siguiente manera:

Estudio sistemático e interdisciplinario del delito y de los factores problemáticos que alteran la convivencia social e interesan a la investigación penal (sociodemográficos, espaciales y temporales, entre otros), para apoyar la función constitucional asignada a la Fiscalía General de la Nación y propender por la garantía de los derechos fundamentales de las víctimas a la verdad, la justicia, la reparación y la no repetición. (Colombia, Fiscalía General de la Nación, 2012, Directiva 001, p.107).

Dentro de la misma directiva 01 de 2012, un caso ilustrativo de plan criminal podría ser el siguiente: 
Situación fáctica representativita de los patrones de conducta delictiva característica de determinada organización criminal. A partir de la priorización del caso ilustrativo se deberá (i) construir el respectivo contexto;(ii) acumular las actuaciones a cargo de la Fiscalía General de la Nación que evidencien la existencia de la organización criminal y la ejecución de las conductas ilícitas que le puedan ser atribuidas a sus presuntos miembros, se trate o no de la misma clase de delito; y (iii) emplear los esquemas de imputación penal que resulten legalmente idóneos para investigar, y acusar a los presuntos máximos responsables, colaboradores y financiadores. Su resolución debe tener un amplio efecto reparador. (Colombia, Fiscalía General de la Nación, 2012, Directiva 001, p.107).

De conformidad con ésta directiva, el concepto de contexto se define de la siguiente manera:

Contexto: Marco de referencia contentivo de aspectos esenciales, acerca de elementos de orden geográfico, político, económico, histórico y social, en el cual se han perpetrado delitos por parte de grupos criminales, incluidos aquellos en los que servidores públicos y particulares colaboran con aquéllos. Debe igualmente comprender una descripción de la estrategia de la organización delictiva, sus dinámicas regionales, aspectos logísticos esenciales, redes de comunicaciones y mantenimiento de redes de apoyo, entre otros. No bastará con la descripción de la estructura criminal o una enunciación de sus víctimas, sino que se deberá analizar su funcionamiento.

La creación de contextos persigue:(i) conocer la verdad de los sucedido;(ii) evitar su repetición; (iii) establecer la estructura de la organización delictiva; (iv) determinar el grado de responsabilidad de los integrantes del grupo y de sus colaboradores;(v) unificar actuaciones al interior de la Fiscalía con el fin de lograr esclarecer patrones de conducta, cadenas de mando fácticas y de iure; y (vi) emplear esquemas de doble imputación penal, entre otros aspectos. 
A efectos de construir los contextos, se deberán recaudar y valorar en su conjunto, de forma ponderada y sistemática, diversas fuentes de información, incluida aquella que quieran suministrar las víctimas.

De igual manera, se deberán adoptar las medidas procesales necesarias para que los elementos que permitan construir el contexto puedan servir, a su vez, como material probatorio y evidencia física en las respectivas indagaciones o procesos penales que surjan a partir de los casos o situaciones priorizados, o en otros.

No constituye contexto el simple recuento anecdótico de acontecimientos ni tampoco el relato de hechos inconexos. (Fiscalía General de la Nación, 2012, Directiva 001, p.108).

Criterio de priorización: Parámetro lógico que sirve para focalizar la acción investigativa de la Fiscalía General de la Nación hacia determinadas situaciones y casos, con el fin de asegurar un mayor impacto y un mejor aprovechamiento de los recursos administrativos y logísticos. (Colombia, Fiscalía General de la Nación, 2012, Directiva 001, p.108).

Fines de la priorización: La política de Priorización, busca alcanzar los siguientes fines:

- Seguridad ciudadana. La posibilidad de asociar casos, a partir de la identificación de elementos comunes, permite combatir de manera más efectiva la criminalidad organizada.

- Conocimiento del contexto de conflicto armado. La construcción de los escenarios delictivos en todas sus dimensiones es necesario para abordar procesos de justicia transicional.

- Legitimidad y eficacia en la administración de justicia. La racionalización de los recursos de la Fiscalía General de la Nación permite que se administre justicia con eficacia y trasparencia hacia la ciudadanía, lo que a su vez posibilita reducir la impunidad.

- Atender las exigencias de la sociedad civil. Los representantes de los distintos sectores de la sociedad han planteado la necesidad de estudiar la criminalidad en su contexto, para así 
desarticular de manera más efectiva a los grupos que vulneran gravemente los derechos humanos y que atentan contra sus defensores y defensoras.

Bajo ninguna circunstancia, los criterios de priorización serán interpretados y aplicados como meros instrumentos de descongestión judicial. (Fiscalía General de la Nación, 2012, Directiva 001, p.109).

Máximo responsable: El concepto de máximo responsable se aplica respecto a dos categorías diferentes, a saber:(i) aquel que dentro de la estructura de mando y control de la organización delictiva sabía o podía prever razonablemente la perpetración de crímenes en desarrollo de la ejecución de los planes operativos; y (ii) de manera excepcional, se trata de aquellas personas que han cometido delitos particularmente notorios, con independencia de la posición que ocupaban en la organización delictiva. (Fiscalía General de la Nación, 2012, Directiva 001, p.109).

- Patrones criminales: Conjunto de actividades, medios logísticos, de comunicación y modus operandi delictivo, desarrollados en un área y periodo de tiempo determinados, de los cuales se pueden extraer conclusiones respecto a los diversos niveles de mando y control de la organización criminal. Su determinación ayuda a establecer el grado de responsabilidad penal de sus integrantes y hace parte fundamental de la construcción del contexto.

- Test de priorización: Juicio que permite realizar una ponderación entre los diversos criterios de priorización a efectos de recomendar o decidir sobre una situación o caso, y la metodología será la siguiente:

- Adelantar un análisis criminal previo.

- Examinar el caso o la situación bajo estudio con la totalidad de los criterios de priorización.

- Adoptar la respectiva recomendación o decisión, según sea el caso, debiendo cumplir para ello con una fuerte carga argumentativa. (Colombia, Fiscalía General de la Nación, 2012, Directiva 001, p.107). 
De conformidad con las definiciones anteriores, dicha directiva es reconocida como "nuevo sistema de investigación y de gestión" de unos criterios de priorización de situaciones y casos; este sistema se estructura a partir del esclarecimiento de un conjunto de conceptos y de definiciones y de la explicación de los fundamentos y limitaciones, que con relación a la "política de priorización" se han previsto en diversas fuentes del derecho internacional de los derechos humanos, del derecho internacional humanitario y del derecho comparado.

En la directiva, se exponen las razones constitucionales que justifican la priorización de situaciones y casos, y en particular a la forma como se preserva el principio-derecho de igualdad y el derecho fundamental de acceso a la administración de justicia. Se destacan los principios de unidad de gestión y de jerarquía de que goza el Fiscal General de la Nación al interior de ésta entidad, y de su competencia para participar en el diseño de la política criminal del Estado.

Por último, se desarrolla el alcance y el contenido de los criterios de priorización objetivo, subjetivo y complementario, para ser aplicados en el contexto colombiano; y con el propósito de implementar el nuevo sistema, se establecen tres niveles de gestión de los criterios de priorización de situaciones y casos, dentro de la estructura de la Fiscalía General de la Nación.

\subsubsection{El análisis de contexto en el Acto Legislativo No. 01 de 2012}

Por medio de esta reforma legislativa de carácter transitorio, que fuera introducida por el Acto Legislativo No. 1 de 2012, se incorporan los elementos sustanciales del análisis de contexto.

Para comprender su alcance, a continuación se mencionarán, los contenidos normativos de la reforma constitucional, posteriormente, se estudiarán las disposiciones relacionadas con la metodología bajo estudio, y finalmente se resumirán sus líneas sustanciales.

Publicado el día 31 de julio de 2012 en el Diario Oficial, el Acto Legislativo No. 01 de 2012, "Por medio del cual se establecen instrumentos jurídicos de Justicia Transicional en el 
marco del artículo 22 de la Constitución Política y se dictan otras disposiciones", y se compone de cuatro preceptos que consagran tres nuevos artículos transitorios definitorios de nuevas herramientas para la Justicia Transicional.

El artículo $1^{\circ}$., el cual incorpora en la Constitución el artículo 66 transitorio, que determina el objeto de las leyes en el marco de la Justicia Transicional, en el cual, se reconocen mecanismos de selección, priorización, gravedad y representatividad, así como requisitos y condiciones en el ejercicio de la acción penal y de la potestad punitiva del Estado, como expresión de un trato benéfico a cambio del compromiso con la paz, la verdad y la reparación a las víctimas.

El artículo $2^{\circ}$., el cual, restringe temporalmente la competencia legal en estas materias, sin señalar qué sucede en caso de que el Legislativo deje vencer el término sin ejercerla.

El artículo $3^{\circ}$., que introduce en la Constitución el artículo 67 transitorio, para determinar los delitos conexos, excluyendo a los delitos políticos, y excluyendo de esta conexidad a los crímenes de lesa humanidad y de genocidio cometidos en forma sistemática, y el artículo $4^{\circ}$, que establece la entrada en vigencia de la reforma constitucional a partir de su promulgación.

Las disposiciones de dicha reforma constitucional que poseen mayor interés para el análisis desde el derecho constitucional, se encuentran en el artículo $1^{\circ}$., del Acto Legislativo No. 1 de 2012, que incorpora el artículo 66 transitorio constitucional, por el cual, se instituye un conjunto de principios, conceptos y reglas desde el ámbito de la Justicia Transicional, y que se presentan a continuación.

Por ejemplo en el inciso $1^{\circ}$. del artículo $1^{\circ}$. del Acto Legislativo en mención, se incluyen tres normas definitorias que son los siguientes:

i) el carácter excepcional de la Justicia Transicional, ii) el objetivo especial de la paz, con la muy especial protección de los derechos de las víctimas; y, iii) la opción de establecer 
por vía de ley estatutaria un régimen diferenciado para los actores en conflicto. (Barbosa \& Bernal, 2015, p.147).

Lo que enfatiza el artículo 66 transitorio constitucional, inciso $1^{\circ}$., es el carácter excepcional de los instrumentos de Justicia Transicional y la finalidad prevalente de la figura, es decir, la de "facilitar la terminación del conflicto armado interno y el logro de la paz estable y duradera, con garantías de no repetición y de seguridad para todos los colombianos". (Barbosa \& Bernal, 2015, p.147).

En relación con el segundo aspecto del mismo inciso, se contempla el objetivo directo de tales instrumentos, cual es garantizar "en el mayor nivel posible, los derechos de las víctimas a la verdad, la justicia y la reparación”. (Barbosa \& Bernal, 2015, p.147).

Y como tercer elemento, se faculta al legislador para disponer, mediante ley estatutaria, un tratamiento diferenciado a los distintos actores del conflicto, tanto a los que conocemos como alzados en armas como a los agentes del Estado.

Se destaca además, la última facultad otorgada por el constituyente y por cuya naturaleza se entiende que el legislador podrá no ejercer la competencia normativa y de ésta forma mantener la regla general de la igualdad formal, o al contrario, ejercerla para establecer un trato distinto, entre las organizaciones que han cometido delitos dentro del conflicto como entre los individuos actores de estos mismos.

El inciso $2^{\circ}$., de la misma norma, otorga una habilitación al legislador para concebir instrumentos al servicio de la justicia o función punitiva del Estado y de la verdad o de la función reparadora de la Justicia Transicional.

Se le da un mandato a al legislador por vía de ley estatutaria, para que en ella se establezcan "instrumentos de Justicia Transicional de carácter judicial o extrajudicial”, con el fin de "garantizar los deberes estatales de investigación y sanción". 
Aunque se trate de instrumentos de naturaleza judicial o no, el objetivo de los mismos es la "justicia" en términos de esclarecimiento de la verdad y reparación de las víctimas. "En cualquier caso se aplicarán mecanismos de carácter extrajudicial para el esclarecimiento de la verdad y la reparación de las víctimas".

La aplicación de mecanismos de carácter extrajudicial, están dirigidos al legislador y se justifican en razón de la dificultad que en los procesos judiciales de distinto orden comporta en garantizar, la verdad y la reparación a las víctimas, dadas las exigencias del derecho probatorio previstas para la imputación de responsabilidad y para la definición de sus consecuencias.

En el inciso $3^{\circ}$. del artículo $1^{\circ}$. del Acto Legislativo No. 01 de 2012, se establece la creación de una Comisión de la Verdad y de sus posibles funciones y este mecanismo extrajudicial, sería distinto de los mecanismos extrajudiciales mencionados en el inciso anterior.

En relación con el "mandato de comisión", éste "podrá incluir la formulación de recomendaciones para la aplicación de los instrumentos de Justicia Transicional, incluyendo la aplicación de los criterios de selección”, en el caso de que el legislador estime conveniente que dicha atribución debe hacer parte de las competencias y funciones de la comisión.

Lo que en realidad podrá emitir, sería algunas "recomendaciones" en relación con herramientas o medidas previstas en la Justicia Transicional, incluidas las que sirvan "para la aplicación de criterios de selección".

El inciso $4^{\circ}$, de la misma disposición constitucional transitoria, determina los ingredientes del análisis de contexto dentro del marco de la Justicia Transicional, según se desprende de sus elementos semánticos, lingüísticos y de sintaxis.

De esta forma, se logra apreciar que en el inciso $4^{\circ}$, se consagra un acuerdo decisivo, para la valoración de la constitucionalidad de la Directiva 01 de 2012 de la Fiscalía General de la Nación, al señalar: "Tanto los criterios de priorización como los de selección son inherentes a los instrumentos de Justicia Transicional”. 
A la luz de ésta norma constitucional, el constituyente derivado colombiano les ha atribuido a las técnicas de selección y de priorización la condición de herramientas para la investigación penal, que son reconocibles como parte de la Justicia Transicional, ya que pos su naturaleza están unidas a la misma y no se pueden separar de ella. El carácter inherente de los criterios mencionados, incluye la condición de ser necesarios para que exista Justicia Transicional, y como la de ser criterios inconcebibles por fuera de dicho marco de Justicia.

Este mismo criterio, reconoce en cabeza del Fiscal General, una función derivada del propio mandato de la Constitución, por medio del cual éste "determinará criterios de priorización para el ejercicio de la acción penal", como una competencia de orden constitucional, cuya atribución resulta natural, pues bajo las condiciones excepcionales en las cuales aplica la Justicia Transicional quién determina quién va primero o quién va después dentro de la investigación penal, debe ser el órgano encargado de llevar la política criminal desde la administración de justicia.

Por otra parte, la selección de los delitos que se investigan, y de los que no se investigan corresponde al legislador, y es una función que debe ejercerse mediante ley estatutaria de iniciativa exclusiva del Gobierno Nacional, y se fija, previa sujeción al límite infranqueable de que en aplicación a los criterios de selección definidos, el Estado colombiano y sus autoridades políticas cumplan con las obligaciones "de investigar y sancionar las graves violaciones a los Derechos Humanos y al Derecho Internacional Humanitario”.

En relación con los contenidos, el apartado en examen dispone en esa ley lo siguiente:

i) Se determinen los "criterios de selección" que debe permitir (a la Fiscalía) centrar "los esfuerzos en la investigación penal de los máximos responsables de todos los delitos que adquieran ciertas connotaciones", como crímenes de lesa humanidad, genocidio o crímenes de guerra cometidos de manera sistemática; ii) se tenga en cuenta la gravedad y representatividad de los casos para determinar los criterios de selección; iii) se establezcan los casos, requisitos y condiciones en los que 
procedería la suspensión de la ejecución de la pena; iii) se definan los casos en los que corresponda la aplicación de sanciones extrajudiciales, de penas alternativas, o de modalidades especiales de ejecución y cumplimiento de la pena; y iv) se autorice la renuncia condicionada a la persecución judicial penal de todos los casos no seleccionados. (Barbosa \& Bernal, 215, p.150).

En relación con esta regulación de carácter estatutario del artículo $2^{\circ}$. transitorio del Acto Legislativo en mención, se prevé un límite de tiempo de cuatro años para el ejercicio de la competencia por parte del Congreso de la República, contado a partir de la presentación del proyecto de ley por parte del Gobierno, pero no se da ninguna solución, en caso de que el legislador no profiera en dicho término todas las leyes relacionadas con los instrumentos penales contemplados en el inciso $4^{\circ}$., del artículo $1^{\circ}$.

De tal forma, el Congreso se despoja de todo su poder constitucional de legislar, lo cual, generaría un vacío normativo pleno que no permite que operen las medidas constitucionales de la Justicia Transicional que son autorizadas a falta de normas legales durante dicho tiempo, y transcurridos los cuatro años sin que el legislador profiera las normas estatutarias, la regulación pasará por defecto al Gobierno Nacional.

La definición de estas medidas, se establecen con una nueva presentación del proyecto de ley por parte del Gobierno, para de alguna manera volver a activar la competencia legislativa. Es decir, que debe ser el legislador quien debe fijar los instrumentos de Justicia Transicional autorizados por el constituyente y que son tan importantes para alcanzar sus fines de la justicia, la reparación y la paz, que justifican el régimen de excepción que se establece, a causa del conflicto armado interno.

El inciso $5^{\circ}$., del artículo 6 transitorio de la Constitución Política, presenta algunas condiciones para la aplicación de los instrumentos constitucionales mencionados que son:

1. "La dejación de las armas", 2.El reconocimiento de responsabilidad", 3. "La contribución al esclarecimiento de la verdad y a la reparación integral de las víctimas, la 
liberación de los secuestrados", y 4. "La desvinculación de los menores de edad reclutados ilícitamente que se encuentren en poder de los grupos armados al margen de la ley". (Barbosa \& Bernal, 2015, p.151).

Por su parte, el parágrafo $1^{\circ}$., determina, la condición subjetiva para acceder a la aplicación de los instrumentos de "Justicia Transicional a grupos armados al margen de la ley que hayan participado en las hostilidades".

Dicha condición precisa lo siguiente:

i) "se limitará a quienes se desmovilicen colectivamente, en el marco de un acuerdo de paz", o ii) "a quienes se desmovilicen de manera individual (...), de conformidad con los procedimientos establecidos y con la autorización del Gobierno Nacional". (Barbosa \& Bernal, 2015, p.151).

La autorización por parte del Gobierno, para la aplicación de mecanismos transicionales en el caso de desmovilización individual, es una atribución explicable desde la dimensión política de las funciones y poderes del Gobierno y del Jefe de Estado en relación a la paz y al orden público. Pero al mismo tiempo se discute, en términos de garantías constitucionales mínimas, pues aunque el procedimiento de aplicación esté previsto en la ley, el hallarse supeditada a la decisión del Gobierno disminuye el significado de la reserva en favor del legislador y su fundamento democrático, representativo y pluralista, para poder habilitar el carácter discrecional de los instrumentos; por tal razón, en desarrollo del Acto Legislativo presente, se deben establecer los criterios a los que se debe sujetar el ejercicio de dicha atribución.

El parágrafo $2^{\circ}$., del artículo 66 transitorio, establece a quienes directamente no pueden aplicarse "los instrumentos de justicia transicional", como son (i) "los grupos armados al margen de la ley que no hayan sido parte en el conflicto armado interno" y (ii) "a cualquier miembro de un grupo armado que una vez desmovilizado siga delinquiendo", previsión que otorga garantías de seguridad e igualdad jurídicas. 
Finalmente, los elementos sustanciales que ofrece el Acto Legislativo No. 01 de 2012, para entender el contexto, son los siguientes:

- Como régimen de Justicia Transicional, contempla normas de carácter excepcional. Con todo, no se establecen límites para delimitar en el tiempo y las circunstancias y la transitoriedad del régimen constitucional establecido mediante dicho Acto Legislativo No. 01 de 2012.

- Su finalidad es alcanzar la paz y el mayor nivel posible de garantía de los derechos de las víctimas.

- Dentro de sus previsiones, tenemos la competencia en cabeza del legislador, bajo la iniciativa exclusiva del Gobierno, para establecer la selección de los delitos por investigar y no, a la vez que se reconoce en cabeza del Fiscal General de la Nación la función de priorizar dentro de la investigación penal. Tanto la selección como la priorización, son criterios inherentes, esto es, entendidos como necesarios y/o propios de la Justicia Transicional.

- Como criterios objetivos que limitan desde la Constitución la facultad legislativa de selección, se impone la investigación de las violaciones a los derechos humanos y al derecho internacional humanitario, así como ciertos delitos con connotaciones de crímenes de lesa humanidad, genocidio o crímenes de guerra cometidos de manera sistemática, y de otros delitos, especialmente afrentosos en razón de su gravedad y representatividad. A su vez, lo que se persigue con la selección de los delitos es ejercer la acción penal frente a los máximos responsables, como previsión que se conecta directamente con el propósito de mayor protección de las víctimas. Tales criterios poseen razonablemente un efecto normativo irradiador sobre la interpretación y desarrollo de la función de priorizar los delitos cometidos dentro del conflicto armado propia de la Fiscalía.

- Se reconoce la competencia legislativa de autorizar la participación de las comisiones de la verdad en la recomendación de los casos seleccionados y por priorizar. No obstante su carácter facultativo, puede entenderse como un mecanismo apto y deseable 
para incorporar a la sociedad y a las víctimas en decisiones significativas para sus derechos.

- Para el caso de la no selección de ciertos delitos por parte del legislador, se prevén criterios para la aplicación de medidas alternativas de sanción, con las cuales se evidencia la pretensión de cubrir en todo caso el derecho de las víctimas a la justicia, aun cuando se prescinda de la investigación penal o de la punición propiamente dicha. (Barbosa \& Bernal, 2015, p.153).

De la misma forma, se incluyen condiciones mínimas de carácter objetivo que no pueden ser desatendidas en la regulación legislativa, para acceder a los beneficios penales de la aplicación de los instrumentos de la Justicia Transicional y para mantenerlos, que son los siguientes:

- Se establece un término para el ejercicio de las facultades para el legislador en la expedición de la ley estatutaria de iniciativa gubernamental para la definición de los criterios de selección de los delitos por investigar y de los restantes mecanismos alternativos ante la falta de persecución o de sanción penal. Por tanto y en razón de la trascendencia que tales medidas poseen para los propósitos del régimen de Justicia Transicional del Marco Jurídico para la Paz, el vencimiento de dicho término no habilita su definición ni por el Gobierno ni menos aún por la Fiscalía, y por tanto su definición legislativa podrá establecerse con la nueva presentación del proyecto de ley por el Gobierno, que activa otra vez la competencia de carácter temporal del Congreso.

- En línea con lo anterior, son muchos los aspectos contemplados en la reforma constitucional del Marco Jurídico para la Paz, muchos los ingredientes normativos de las medidas previstas entregadas por el Constituyente al Legislador, con lo cual los alcances del régimen de Justicia Transicional del Marco Jurídico para la Paz solo podrán reconocerse en plenitud una vez se profieran las leyes estatutarias correspondientes. Con todo, para los efectos de la presente investigación se debe destacar que no ocurre lo mismo con la competencia atribuida al Fiscal General de la Nación para determinar los criterios de priorización en el ejercicio de la acción penal de los delitos cometidos dentro del conflicto, la cual puede ser ejercida de manera directa. (Barbosa \& Bernal, 2015, p.153). 


\subsubsection{La Jurisprudencia Constitucional de Justicia y Paz}

Dentro de la jurisprudencia constitucional producida con ocasión del estudio de constitucionalidad de las leyes que desde el año 2005 han configurado el régimen transicional de justicia y paz, se encuentran referentes a los problemas, objetivos y finalidades próximas de los conceptos que estructuran el análisis de contexto como método de investigación criminal.

Por ejemplo, en la Sentencia C - 370 de 2006, que se configura como el primer estudio de constitucionalidad de la Ley 975 de 2005, al preguntarse la Corte, si los mecanismos consagrados en ella "servirán adecuadamente a la reconstrucción del fenómeno macro criminal y a la investigación de los delitos incluidos los que la humanidad entera ha considerado de la mayor gravedad”. (Barbosa \& Bernal, 2015, p.154).

Se responde negativamente, debido a que la configuración normativa ofrece una protección para dicho postulado desproporcionada respecto de la desprotección para las víctimas y su derecho a la verdad, esto significa, que se desconocen sus deberes "de adelantar investigaciones serias y exhaustivas sobre los hechos dentro de un plazo razonable", y de garantía del "derecho de las víctimas a conocer la verdad integral y fidedigna de los ocurrido". (Barbosa \& Bernal, 2015, p.154).

Es importante tener presente el énfasis que hace la misma corporación al señalar lo siguiente:

sólo la identificación completa de la cadena de delitos cometidos por cada uno de estos grupos armados específicos permite conocer la real dimensión de lo sucedido, identificar a las víctimas, repararlas, y adoptar medidas serias y sostenibles de no repetición. (Barbosa \& Bernal, 2015, p.155).

Por similares razones, la Corte declara la constitucionalidad condicionada de la ley sobre la revocatoria del beneficio de la confesión, de la siguiente manera: 
En el entendido de que también se revocará (...) cuando se haya ocultado en la versión libre la participación del individuo desmovilizado como miembro del grupo en la comisión de un delito relacionado directamente con su pertenencia al grupo.

Lo anterior, porque el privilegio de la alternatividad penal de Justicia y Paz se define de la siguiente manera:

es un medio idóneo para promover el derecho a la verdad siempre y cuando que este mismo sea revocable, pues en el caso de que no lo sea, aún en las circunstancias en que el miembro de un bloque o frente oculte su participación en la comisión, no de un delito cualquiera, sino precisamente de uno que guarda relación directa con su pertenencia a dicho grupo específico y cometido con ocasión de su vinculación al mismo, la afectación del derecho a la verdad de las víctimas sería manifiestamente desproporcionada. (Barbosa \& Bernal, 2015, p.154).

De lo anterior se puede colegir, que enfoque de la investigación caso por caso de manera aislada, es inoperante frente a la magnitud del fenómeno criminal de sistema y ante la importancia de reconocer el delito dentro del contexto de toda la organización criminal.

Esta misma aproximación, se presenta con el problema de la responsabilidad civil en la justicia penal de la Ley de Justicia Paz, como régimen de responsabilidad solidaria entre el postulado que es penalmente responsable y el grupo armado con el cual ha actuado, todo esto, "en virtud de la relación de causalidad que se estructura entre las conductas delictivas que generan el daño y la actividad en concreto de ese grupo específico que actúa al margen de la ley al cual pertenecieron los desmovilizados”. (Barbosa \& Bernal, 2015, p.154).

De dicha relación de causalidad, surge la necesidad de entender el delito que se está investigando desde el marco de contextos criminales.

Se considera además, como un antecedente jurisprudencial y normativo de los elementos propios de la metodología de investigación en contexto, la Sentencia C - 715 de 2012, decisión 
en la cual la Corte declaró inexequible la norma de la Ley 1448 de 2011, que otorgaba a quienes se acogieran al proceso de restitución de tierras, "y confiese la ilegalidad de los títulos o el despojo de las tierras o de los derechos reclamados (...) en él, el beneficio del principio de oportunidad ( art.120 Ley 1448 de 2011)", al encontrar que dicha norma "desborda los límites constitucionales impuestos al Legislador por los derechos de las víctimas”. (Barbosa \& Bernal, 2015, p.156).

Lo anterior, teniendo en cuenta que dicha figura opera sin tener actividad investigativa ninguna, a pesar del contexto dentro del cual, se producen el despojo de las tierras, con los cual se "vulnera el pierden justo" ya que "se renuncia al deber de investigar, juzgar y sancionar a los responsables de graves delitos".

Esto implica, que con ocasión de la Justicia Transicional trazada desde las leyes de Justicia y Paz, la Fiscalía General de la Nación ha sido habilitada para investigar a partir de la construcción de contextos, como necesario para aplicar medidas penales del proceso penal transicional, reconocidas constitucionalmente legítimas, y dicha competencia, se confirma desde el contenido de actos de la Fiscalía previos a la Directiva 01 de 2012, que conducen a aplicar tales pautas de investigación a partir de contextos sociales y criminales.

\subsubsection{La Sentencia C - 579 de 2013}

\section{A. El deber de garantía}

El consenso respecto a la realización de los derechos humanos, parte del punto de que su goce se condiciona a que los Estados cumplan, con base en la jurisprudencia de la Corte Interamericana de Derechos Humanos, con tres obligaciones de respeto, protección y garantía, y que son las siguientes:

i) no repetición; ii) tutela judicial efectiva; iii) reparación y verdad, y también el deber iv) “investigar, juzgar y sancionar las graves violaciones a los Derechos Humanos, y al 
Derecho Internacional Humanitario (justicia)", y v) el deber de prevenir tales conductas (fundamento 9.9). (Barbosa \& Bernal, 2015, p.160).

Al centrar los esfuerzos en la investigación penal, la Corte Constitucional destacó cómo en una de sus ponencias en el Senado de la Republica, se dejaba claro que el sistema de investigación caso por caso, no deja la posibilidad de establecer patrones y contexto, para garantizar los derechos de las víctimas y de la sociedad, por lo tanto, se debe concentrar esfuerzos y recursos para identificar a los máximos responsables y esclarecer el sistema de macrocriminalidad en el cual los hechos ocurrieron.

Por lo tanto, son elementos de naturaleza jurídica, material y técnica, los que exigen a la actuación del Estado por medio de la Fiscalía General de la Nación, para garantizar el cumplimiento del deber frente a los derechos de las víctimas.

\section{B. La priorización: riegos y necesidad de establecer criterios de priorización}

Al respecto, la Corte determinó lo siguiente:

adopción de criterios formales para la priorización puede ser esencial para llevar a cabo una priorización coherente de los crímenes de guerra, pues de esta manera el sistema acusatorio se puede apoyar en herramientas que permiten clasificar los casos que merecen acudir primero ante el sistema judicial. (Barbosa \& Bernal, 2015, p.161).

La definición de los criterios de priorización se impone por el impacto político y jurídico que poseen ante la sociedad y ante las víctimas, y por razón de las obligaciones internacionales

asumidas y frente al principio de igualdad, y por la necesidad de legitimar e incrementar la confianza en la institución que se encarga de perseguir el delito.

Los criterios de priorización más destacados son los siguientes, de acuerdo con la Corte:

i) Máximo responsable, el cual, se debe entender, de la siguiente manera: 
aquella persona que tiene un rol esencial en la organización criminal para la comisión de cada delito, es decir, que haya: dirigido, tenido el control o financiado la comisión de los delitos de lesa humanidad, genocidio y crímenes de guerra cometidos de manera sistemática. (Barbosa \& Bernal, 2015, p.161).

De acuerdo a dicha definición, incluye a líderes, dirigentes y comandantes o a quienes tengan de alguna manera posición y jerarquía dentro de la organización. Para identificar al máximo responsable opera por medio del sistema de doble imputación de todo crimen internacional, es decir, tanto por el hecho individual (imputación individual) y por el hecho total que describe el respectivo contexto de comisión (imputación colectiva).

ii) Delitos cometidos de manera sistemática, los cuales se deben entender de la siguiente manera:

los crímenes de guerra, el genocidio y los crímenes de lesa humanidad que se producen en un contexto de violencia sistemática o de macrocriminalidad, y que por lo tanto implican la "existencia de un nexo del crimen con el conflicto armado". (Barbosa \& Bernal, 2015, p.162).

De esta forma, se distinguen de los crímenes ordinarios, por el elemento de violencia sistemática o macrocriminalidad, es decir, el componente esencial que crea la diferencia que más allá de su masividad o generalidad, se manifiesta, en la necesidad de que tales conductas no tengan carácter aislado, para que en el caso de los crímenes de guerra, tales delitos tengan un nexo con el conflicto armado como parte de un plan o de una política.

iii) Gravedad y representatividad. Centrar la investigación en los máximos responsables de los delitos internacionales, se complementa por el constituyente con los criterios de gravedad y de representatividad, y que son instrumentos básicos "para la construcción de los casos, pues sin (ellos) se volvería a la metodología de la investigación caso a caso" (Barbosa \& Bernal, 2015, p.162). 
Se debe tener presente que el marco transicional no es una mezcla de asuntos, "sino que implica la construcción de macroprocesos en torno a una serie de elementos comunes determinados por factores relacionados con la gravedad y la representatividad", los cuales, tienen en cuenta factores de tiempo, modo y lugar, los sujetos, la escala, la comisión o la evidencia disponible.

\section{Priorización e impunidad}

Es importante aclarar que una rápida protección judicial, requiere de una estrategia de investigación y de juzgamiento especial, debido a que la investigación caso a caso de violaciones de los derechos humanos, puede terminar en una situación generalizada de impunidad.

Es por ello tan relevante enfocar la investigación hacia los máximos responsables y ellos parte de la imposibilidad fáctica de tener una estrategia de investigación, que proceda contra todos los sospechosos, dentro de un proceso de Justicia Transicional.

Por otra parte y de acuerdo con la argumentación de la Corte desde las fuentes del Derecho Internacional de los Derechos Humanos y del Derecho Penal Internacional, se le impone a los Estados ante violaciones masivas de los Derechos Humanos, aplicar instrumentos de Justicia Transicional para evitar situaciones de impunidad, y en ese mismo orden establecer prioridades en las demandas de justicia.

Por tal razón la Corte concluye que el Acto Legislativo No. 1 de 2012 no patrocina, la impunidad de delitos atroces, sino que introduce un cambio de estrategia en la investigación para enfrentar los niveles de impunidad en el estudio de caso por caso, estructura en torno de macro procesos con participación de las víctimas y de la construcción de contextos sociales y de las estructuras criminales. 


\section{Proceso de selección y priorización y las garantías a favor de las víctimas}

La metodología de investigación en contexto, debe ser seria, imparcial, cumplida dentro de un plazo razonable, con la participación de las víctimas y de sus familiares, entre otros. Además, dicha investigación debe ser efectiva en los que respecta a la determinación de los hechos, "lo que implica que los agentes encargados deben planear las líneas de investigación y los medios más adecuados para darles cumplimiento”. (Barbosa \& Bernal, 2015, p.164).

Por otra parte, se puntualiza además que "la suspensión total condicional de la ejecución de la pena es para los casos no seleccionados y no para los seleccionados"; que "toda víctima cuyo caso no haya sido seleccionado o priorizado (dispondrá) de los recurso efectivos contra la decisión", y que la utilización de los criterios de selección determina, que "no implica una renuncia automática de los casos no seleccionados que constituyan crímenes de lesa humanidad, genocidio o crímenes de guerra, sino que la misma dependerá de criterios subjetivos y objetivos que deberán ser señalados por la Ley Estatutaria”. (Barbosa \& Bernal, 2015, p.164).

La Corte, señala además, que la falta de seriedad en la aplicación de los criterios de priorización y selección, y un inadecuado contexto y análisis, compromete a la Fiscalía General de la Nación y pone en peligro del éxito del proceso de Justicia Transicional al cual, dichas técnicas se integran.

Por lo tanto, se debe investigar, juzgar y sancionar, las conductas que representan mayores violaciones al derecho internacional de los derechos humanos y al derecho internacional humanitario, como son los crímenes de lesa humanidad, el genocidio, y los crímenes de guerra.

Para que proceda la aplicación de los criterios de selección y de priorización, se debe realizar lo siguiente:

el Estado debe exigir al grupo armado al margen de la ley una contribución efectiva y real al esclarecimiento de la verdad y a la reparación de las víctimas, la liberación de todos los 
secuestrados y la desvinculación de todos los menores de edad que se encuentren en poder de los grupos armados al margen de la ley. (Barbosa \& Bernal, 2015, p.165).

Por otra parte, se deben revelar los hechos constitutivos de graves violaciones a los Derechos Humanos y al Derecho Internacional Humanitario.

De lo anterior se logra concluir que la Corte, advierte gran importancia de que con la selección y la priorización de los delitos se protejan los derechos de las víctimas de los casos incluidos o no dentro de dichos instrumentos de Justicia Transicional, y además, se evidencia la diferencia entre las dos figuras, debido a que la selección que le corresponde al legislador define los hechos y los delitos por investigar, en razón de su naturaleza y características y la priorización, la cual, le corresponde a la Fiscalía General de la Nación, es la herramienta para ordenar la persecución penal que se encuentra a su cargo, a pesar de verse limitada por criterios previstos dentro de la ley estatutaria.

\section{E. Las técnicas de selección y priorización de situaciones y casos, no sustituyen la Constitución Política de Colombia}

Lo anterior quiere decir, que de conformidad con la Sentencia C - 579 de 2013, las técnicas de selección y de priorización son constitucionales, debido a que ayudan a la construcción de la paz, la reconciliación y la protección de los derechos de las víctimas y de la sociedad y no sustituyen en ningún momento, la fisonomía constitucional del Estado, dirigida por la Constitución Política de Colombia de 1991.

Lo anterior se puede constatar, en las conclusiones de Gonzalo Villa acerca del juicio de sustitución efectuado por la Corte, y en el cual, en dicha sentencia se evidencia lo siguiente:

...el pilar fundamental definido en la premisa mayor del juicio de sustitución (el compromiso del Estado Social y democrático de derecho de respetar, proteger y garantizar los derechos de la sociedad y de las víctimas), conforme a su estructura (como principio), admite restricciones (como las que se pueden derivar de la aplicación de la selección y la 
priorización), y dado que estas posibles restricciones se justifican en aras del logro de "la paz estable y duradera y la sustracción del país del conflicto por medio de la desmovilización de los grupos armados al margen de la ley" (...) la adopción del sistema de Justicia Transicional previsto por la reforma no conlleva el reemplazo del elemento esencial de la Constitución definido en la premisa mayor del juicio de sustitución, porque el grado de no satisfacción o de restricción de seico elemento esencial, se justifica en razón a la importancia de la satisfacción del principio que persigue el acto de reforma. (Barbosa \& Bernal, 2015, p.166).

Por otra parte, dicha explicación se justifica de la siguiente manera: ...con base en el juicio de ponderación (...) por una parte, (...) la incorporación en la Constitución de la estrategia dirigida a agrupar las graves violaciones de derechos humanos en los así denominados "macroprocesos" (organizados a partir de la priorización y los contextos), e imputarlas a sus máximos responsables se encuentra justificada; y por la otra, (...) la aplicación especial a las reglas de juzgamiento se encuentra también justificada siempre y cuando se asegure que, como mínimo, se enjuiciarán los delitos de lesa humanidad, genocidio y crimines de guerra cometidos de manera sistemática. (Barbosa \& Bernal, 2015, p.166).

\subsubsection{Sentencia C - 577 de 2014}

El Acto Legislativo No. 01 de 2012, es objeto de una posterior revisión de constitucionalidad, la cual, fue resuelta en la Sentencia C - 577 de 2014.

Aquí fueron demandados apartes del inciso $4^{\circ}$., del artículo $1^{\circ}$. del Acto Legislativo No.

01 de 2012, en la medida en la que en él se habilita al legislador a determinar mediante ley estatutaria la selección de los delitos que adquieran la connotación de ser crímenes de lesa humanidad, genocidio, o crímenes de guerra, los cuales, han sido cometidos de manera sistemática.

Con lo anterior, se altera la premisa mayor que constituye lo siguiente: 
La obligación de garantizar el acceso a la justicia a las víctimas de esas conductas y el funcionamiento del Estado basado en el respeto y garantías de los derechos humanos, sin discriminación alguna. (fundamento III). (Barbosa \& Bernal, 2015, p.167).

Por otra parte, también fue objeto de acusación el artículo $3^{\circ}$., por considerar que con él, se reemplazaba el pilar fundamental de la democracia como régimen político sometido al principio de la dignidad humana, por un régimen en donde:

Los responsables de graves violaciones a los derechos humanos, infracciones al derecho internacional humanitario, delitos transnacionales y actos de terrorismo tienen derecho a ser candidatos a cargos de elección popular y pueden llegar a ser servidores públicos. (Barbosa \& Bernal, 2015, p.167).

La acusación del inciso $4^{\circ}$., del artículo $1^{\circ}$., se despachó señalando la existencia de la cosa juzgada, y por tal razón, el análisis de la Corte se centró en el artículo $3^{\circ}$., por medio del cual, se introducía el artículo transitorio 67 de la Constitución Política de Colombia.

En la Sentencia acerca del juicio de sustitución, precisa la Corte que el problema en ella radica en analizar si dicho precepto:

Permitiría que fueran considerados delincuentes políticos los autores de graves violaciones a los derechos humanos, infracciones al derecho internacional humanitario, crímenes de guerra, narcotráfico y actos de terrorismo, así como de crímenes de lesa humanidad y genocidio cometidos de forma no sistemática.(fundamento 8). (Barbosa \& Bernal, 2015, p.167).

A los efectos del juicio de sustitución la Corte reconoció como premisa mayor, la participación política como principio fundante y transversal al régimen constitucional colombiano, la cual, resulta esencial en la confrontación, ejercicio y control del poder en un Estado democrático como el establecido a partir de la Constitución de 1991. 
Por esta misma razón, en la misma sentencia se agrega que los límites que a la misma se determinen, no tendrán fundamento en las condenas que hayan sido impuestas por la comisión de delitos políticos o por aquellos delitos conexos a los delitos políticos.

En relación con la premisa menor, la Corte considera lo siguiente:

(i) La competencia para que el legislador estatutario determine qué delitos se consideran conexos al delito político, para efectos de reglar las condiciones de participación en política de miembros de grupos armados en un escenario de postconflicto; (ii) (que) no se podrán establecer como delitos conexos, para los exclusivos efectos de participación en política, los crímenes de lesa humanidad, ni de genocidio cometidos de forma sistemática; (iii) (y) la prohibición consecuente de que, quienes hayan sido seleccionados y condenados por esos delitos no podrán participar en política.(ibíd.). (Barbosa \& Bernal, 2015, p.168).

Los nuevos elementos que han sido introducidos dentro de la Constitución, no alteran ni modifican su identidad, pues los que hacen es desarrollar un principio inmanente de la Constitución, como es, la participación en política de las personas que han sido condenadas por delitos conexos a los delitos políticos, principio que no posee sustento por vía constitucional, y también por la vida del bloque de constitucional en el derecho internacional de los derechos humanos, el cual, es vinculante para Colombia, de conformidad con el artículo 93 de la Constitución Política, aparte de contar con otros fundamentos históricos en normas antecedentes a la Asamblea Constituyente.

La participación política, es entendida como un contenido transversal a la idea de democracia desde el un punto de vista constitucional colombiano, pues dentro del contexto de una sociedad diversa, todos participen, con la finalidad de lograr el objetivo dentro de la justicia transicional, que busca el reconocimiento de interlocutores políticos validos a los antiguos actores del conflicto, para restablecer el orden de una democracia dentro de una sociedad, y en dicho contexto, no tiene cabida las medidas excepcionales que se presentan en búsqueda de la 
paz, tales como, la participación en política de miembros del conflicto armado dentro del escenario del postconflicto.

Pero de conformidad con la Corte, solo podrán participar en política solamente "quienes se desmovilicen y hayan sido condenados, siempre que las acciones por las cuales les fue impuesta la condena sean consideradas como delitos conexos a delitos políticos", esto es similar a como lo establece la Constitución Política de Colombia al determinar que "las condenas por delitos políticos no generarán inhabilidad para ser elegido o nombrado en un cargo público". (Barbosa \& Bernal, 2015, p.167).

Por su parte, el Artículo transitorio 67 de la Constitución Política de Colombia, “estableció límites a la actividad configurativas del legislador en relación con los delitos que determine como conexos al delito político: no podrá establecerse dicha conexidad respecto de los crímenes de lesa humanidad ni de genocidio, cuando éstos sean realizados sistemáticamente". (fundamento 8.1). (Barbosa \& Bernal, 2015, p.169).

La Corte, determina que la limitación al poder del legislador no es insuficiente, en primer lugar, porque no existe ningún parámetro a nivel constitucional que limite la libertad de configuración del poder constituyente constituido al momento de determinar qué delitos son conexos al delito político, para efectos de permitir la participación en política, de quienes hayan sido condenados por la realización de estas conductas.

De esta manera, se crea un margen de apreciación del Estado que le permite adaptar su regulación a las necesidades que pueden llegar a surgir en los proceso que al buscar el objetivo de la paz, requieran a la adopción de marcos de justicia transicional, en los cuales, juega como papel protagónico la reconciliación.

En segundo lugar, porque el precepto acusado, sí consagra límites al legislador de la siguiente manera: 
respecto de i) la concesión de amnistías e indultos, así como de ii) la prohibición de extradición de delincuentes por parte del Estado colombiano; límites que a su vez determinan cuales delitos podrán considerarse como políticos o conexos a delitos políticos cuando estas categorías sean utilizadas con dichos fines. (Barbosa \& Bernal, 2015, p.169).

Con base a lo anterior, no se ha pidió considerar como posible reconocer como delitos políticos los delitos atroces o inhumanos, los homicidios cometidos fuera de combate, el homicidio u otros delitos violentos, contra la persona del Jefe de Estado de miembros de su familia y genocidio, entre otros delitos de alto impacto.

Por otra parte, se debe tener en cuenta, que la participación en política de los sujetos que cometen estas conductas, no afectan los derechos que constituyen la garantía sustantiva que un Estado debe reconocer a las víctimas de estos mismos hechos, además, la Corte determina, que no existe un contenido definitorio, del cual, pueda determinarse que conductas tiene conexidad con el delito político, para facilitar la reincorporación a la comunidad política, de quienes como resultado de un proceso de paz, sean seleccionados y a la vez condenados.

En relación con la noción de contexto se puede afirmar, que "la garantía de participación política, resulta pilar sine qua non en un proceso que busque la paz con garantías de estabilidad y durabilidad". (Barbosa \& Bernal, 2015, p.170), y su diseño debe responder a cada "particular historia, condiciones, contexto, actores involucrados y demás particularidades de quienes son objeto del proceso de justicia transicional".

En lo que respecta a la definición de los delitos conexos al delito político, el juez constitucional observa que la libertad de configuración normativa del legislador estatutario se debe sujetar, a los principios de razonabilidad y proporcionalidad y debe responder a la esencia que identifica a esta categoría de delitos.

Por otra parte, no existe un derecho absoluto de las víctimas a la NO participación de quienes son considerados delincuentes políticos dentro del marco de un proceso de justicia transicional, por medio de la cual, se busque alcanzar el fin del conflicto armado y una paz 
positiva estable y duradera. Dentro del proceso de Justicia Transicional, a la reparación del daño a las víctimas y a la sociedad en general, se suman otras previsiones propias, tales como la consideración del responsable del daño para reincorporarlo a la comunidad política.

Lo anterior significa, que el deber de brindar protección a la víctimas del conflicto armado, no obliga al constituyente derivado a excluir de los espacios de participación política a los responsables de crímenes de guerra, delitos transnacionales, actos de terrorismo o narcotráfico, pues no existen límites que así mismo lo determinen desde el elemento definitorio que sirve a la Corte como parámetro del juicio de sustitución. Sin embargo, el legislador estatutario debe tomar precauciones para que no se reproduzcan las condiciones de afirmación humillante de poder sufridas por las víctimas, e incorporar garantías de no repetición, así como las posibilidades de consolidar estructuras políticas que conduzcan a la paz y a la reconciliación.

La Corte, ha determinado lo siguiente:

el caso de los desmovilizados que sean seleccionados y condenados, su participación en política estará supeditada al cumplimiento de la condena impuesta en el marco del proceso de la justicia transicional y de las demás obligaciones que se impongan a quienes aspiren a esa participación. (Barbosa \& Bernal, 2015, p.171).

Lo anterior significa, que la participación en política es otorgada a quienes hayan saldado su deuda con la sociedad colombiana, y que además hayan cumplido con todas las obligaciones axiales a la reincorporación de los miembros de los grupos armados al margen de la ley que hayan participado dentro del conflicto armado interno, porque a pesar de que no exista un derecho absoluto de las víctimas a que los mismos actores del conflicto no participen en política, si tienen derecho a que los mecanismos de participación que establezcan, no se conviertan en obstáculo para el cumplimiento de los instrumentos de la justicia transicional que forma parte del Marco Jurídico para la Paz.

De esta forma, la corte determina que el artículo 67 de la Constitución Política de Colombia, no sustituye la Constitución porque esta "acorde con el principio definitorio de 
participación política inherente al marco jurídico democrático y participativo”, y además, porque, "en el caso de los desmovilizados que sean seleccionados y condenados en el marco del proceso de justicia transicional", su participación se basa en lo siguiente:

tiene como presupuesto el cumplimiento de una serie de condiciones establecidas por el propio Acto Legislativo No. 01 de 201, que garantizan que no se eluda el deber de investigar, juzgar y sancionar las graves vulneraciones a los derechos humanos.(ibíd., fundamento 9). (Barbosa \& Bernal, 2015, p.171).

Finalmente, se logra determinar que se trata de una decisión que consolida la constitucionalidad del Acto Legislativo No. 01 de 2012 dentro del diseño de la Justicia Transicional, debido a que es coherente con el principio de la democracia participativa, pluralista e incluyente de la Constitución, y que corresponde al contexto dentro del cual se dictó la Carta Política de Colombia de 1991, y que atiende a la exigencias de los contextos de transición.

\subsubsection{La Ley 1592 de 2012}

Dentro de los contenidos de ésta norma, la introducción del análisis de contexto se concreta dentro del ámbito normativo y de interpretación de la Ley de Justicia y Paz, dentro de la aplicación de "criterios de priorización en la investigación y el juzgamiento" de las conductas delictivas objeto de dicha ley, las cuales, se encuentran consagradas en el artículo $1^{\circ}$, de la Ley 1592 que modifica el artículo $2^{\circ}$., de la Ley 975 de 2005.

Dentro del criterio que busca la necesidad de introducir dentro del proceso de investigación, la construcción de contextos, se incorpora el precepto sobre el "Enfoque diferencial", el cual, se utiliza para reconocer "que hay poblaciones con características particulares en razón de su edad, género, raza, etnia, orientación sexual y situación de discapacidad", y dentro del proceso de investigación y la participación de las víctimas, se “deberá contar con dicho enfoque", lo anterior, "sin perjuicio de la aplicación de criterios de priorización", establecidos en el artículo $3^{\circ}$., de la Ley 1592 que adiciona el artículo $5^{\circ}$., a la Ley 975. 
Por otra parte, por medio de esta Ley, se modifica el artículo 15 de la Ley 975 sobre “esclarecimiento de la verdad", para sustituir la investigación de todas las conductas punibles por la investigación mediante la priorización, con garantía "del derecho de defensa de los procesados y la participación efectiva de las víctimas", todo lo anterior, para lograr una lucha organizada y sistemática contra el crimen materia del régimen de Justicia y Paz y lograr el desmantelamiento de las grandes organizaciones delictivas que integran su estructura y actuación.

De lo anterior, se colige lo siguiente:

El fiscal delegado en coordinación con las autoridades de policía judicial, de conformidad con los criterios de priorización, dispondrá la realización de la labores investigativas necesarias con el objetivo de esclarecer el patrón de macrocriminalidad de despojo y abandono forzado de tierras, (artículo 11 de la Ley 1592, que adiciona un nuevo artículo, $15^{\mathrm{a}}$, a la Ley 975 de 2005). (Barbosa \& Bernal, 2015, p.173).

Otro aspecto trente a la priorización como mecanismos de investigación incorporado por la Ley 1592 de 2012 a la Ley Justicia y Paz, se refiere a las competencias de la Fiscalía General para:

Conocer de las investigaciones de los hechos delictivos cometidos durante y con ocasión de la pertenencia al grupo armado organizado al margen de la ley; (...) de las investigaciones que cursen en contra de sus miembros; (...) de las investigaciones que deban iniciarse y de las que se tenga conocimiento en el momento o con posterioridad a la desmovilización. (artículo 16 de la Ley 975 de 290905, modificado por el artículo 12 de la ley 1592 de 2012). (Barbosa \& Bernal, 2015, p.173 - 174).

La novedad que introduce esta Ley, es que tales competencias se ejercerán, de acuerdo con los criterios de priorización que determine el Fiscal General de la Nación, los cuales: 
estarán dirigidos a esclarecer el patrón de macrocriminalidad en el accionar de los grupos armados organizados al margen de la ley y a develar los contextos, las causas y los motivos del mismo, concentrando los esfuerzos de investigación en los máximos responsables. (Barbosa \& Bernal, 2015, p.174).

Lo anterior sin olvidar, que para ese mismo propósito la Fiscalía General de la Nación, adopte mediante resolución el llamado "Plan Integral de Investigación Priorizada". (Artículo 12, que modifica el artículo 16 de la Ley 975 de 2015).

Y como un refuerzo de lo anterior se determina que, "Con el fin de garantizar los derechos de las víctimas, el Fiscal General de la Nación determinará los criterios de priorización para el ejercicio de la acción penal que tendrán carácter vinculante y serán de público conocimiento". (Artículo 13 de la Ley 1592 de 2012, por el cual, se introduce el nuevo artículo, 16A, a la Ley 975 de 2005.

La Ley 1592 de 2012, incorpora los elementos normativos del análisis de contexto, por medio de la herramienta de la priorización que funge, para atender como enfoque diferencial a las víctimas, la investigación de la macrocriminalidad y la persecución de los máximos responsables de los delitos de lesa humanidad cometidos dentro del marco del conflicto armado interno.

\subsubsection{La ley 1654 de 2013 y el decreto ley 016 de 2014}

La Ley 1654 del 15 de julio de 2013, le otorga facultades extraordinarias al Gobierno dirigidas a:

a) Modificar y definir la estructura orgánica y funcional de la Fiscalía General de la Nación y sus servidores;

b) Modificar la Planta de Personal de la Fiscalía General de la Nación (...);

c) Expedir la régimen de carrera especial de la Fiscalía General de la Nación y de sus entidades adscritas y el de las situaciones administrativas de sus servidores; 
d) Crear una institución universitaria como establecimiento público de orden nacional cuyo objeto consistirá en prestar el servicio público superior para la formación y el conocimiento científico de la investigación penal y criminalística... (art. I.). (Barbosa \& Bernal, 2015, p.176).

La exposición de motivos de la Ley 1654 de 2013, se refiere al reforzamiento de las competencias de la Fiscalía General de la Nación para cumplir, con mayor eficacia su función constitucional, con alusión a la priorización y a la construcción de contextos, además, llama la atención que dentro de dicha ley, no existe pauta normativa alguna para incluir tales instrumentos dentro de la forma y funcionamiento de la entidad.

Se debe tener presente que tanto la priorización como el estudio de contextos, solo se han previsto para la investigación penal en las Justicia Transicional, pero en dicha ley no se precisa si su empleo sólo opera en dicho régimen y cómo dicha distinción, podría alterar la composición de la estructura y planta de personal por establecer.

No obstante y en ejercicio de sus facultades extraordinarias, el Gobierno Nacional profiere el Decreto Ley 16 de 9 de enero de 2014, y dentro de él, contempla las funciones del Fiscal General, la formulación de políticas, directrices, lineamientos y protocolos para el cumplimento de las funciones constitucionales y legales de la Fiscalía General de la Nación, para el ejercicio eficiente y coherente de la acción penal, considerada como de obligatorio cumplimiento.

Por otra parte, dicho Decreto también prevé la formulación, dirección y definición de las políticas y estrategias de priorización, para el ejercicio de la actividad investigativa a cargo de la misma entidad, incluyendo como criterios posibles, los que a continuación se mencionaran:

subjetivos, objetivos, complementarios y en especial el contexto de criminalidad social del área geográfica que permitan establecer un orden de atención de casos con el fin de garantizar, en condiciones de igualdad material, el goce efectivo del derecho fundamental de administración de justicia. (Barbosa \& Bernal, 2015, p.177). 
Para lograr lo anterior, se organizarán los comités, que son los encargados de decidir las situaciones y los casos que se hayan priorizado, por otra parte, existirá a la función de dirigir y de coordinar la realización de actividades que permitan la atención y la investigación temprana de los delitos y de las actuaciones criminales, dentro del marco de la Constitución, las leyes estatutarias, el Derecho Internacional de los Derechos Humanos y del Derecho Internacional Humanitario, al igual que la expedición de reglamentos, protocolos, órdenes, circulares y manuales de organización y el procedimientos conducentes a la organización administrativa y el eficaz desempeño de las diferentes funciones asignadas.

De conformidad con el Decreto mencionado, y teniendo en cuenta, las direcciones, dependencias y funciones definidas para la misma entidad, la priorización y la construcción de contextos aparece de forma reiterada y es pieza crucial de la actuación dentro de la Fiscalía.

Del análisis anterior, se logra determinar, que el análisis de contexto como parte de la política criminal, es un elemento definitorio de la actividad de la Fiscalía General de la Nación, traducida en dependencias, las cuales, se encargan de distintas funciones para priorizar y contextualizar, para enfrentar de una manera distinta el fenómeno del crimen, sin entrar a diferenciar si, tales dependencias y funciones actúan, para atender la investigación de los casos sometidos a la Justicia Transicional o también dentro de la investigación penal ordinaria.

\subsection{Fundamentos constitucionales de las políticas de priorización}

La técnica judicial de la priorización implementada por el Fiscal General de la Nación, cuenta con diversos fundamentos constitucionales, que se explicarán a continuación:

\subsubsection{El deber de proteger la vida, honra, bienes, derechos y libertades}

De conformidad con el artículo $2^{\circ}$, de la Constitución Política, se determina que son fines de las autoridades de la República, proteger a todas las personas residentes en Colombia, en su vida, honra, bienes creencias, y demás derechos y libertades. 
De acuerdo con lo anterior, la Corte Constitucional en sentencia T - 406 de 1992, se menciona que los fines estatales constituían valores constitucionales, lo que significa, de que se trata de, "un conjunto de propósitos a través de los cuales se debe mirar las relaciones entre los gobernantes y los gobernados, para que, dentro de las limitaciones propias de una sociedad en proceso de consolidación, irradien todo el tratado constitucional”.

De esta manera, los fines constitucionales, que se constituyen en valores superiores, permiten a las autoridades públicas, entre ellas a las judiciales, gozar de un amplio espacio de discrecionalidad al momento de perseguir su cumplimiento, y si por el contrario, de conformidad con la posición de la misma Corte, si los fines estatales tuvieren la forma de fines constitucionales, estaríamos frente a verdaderas prescripciones jurídicas generales, y por tal razón, el margen de discrecionalidad de las autoridades en el momento de concretarlos sería menor.

En el momento en que el artículo $2^{\circ}$,, de la Constitución Política, establece el deber constitucional de proteger la vida, honra, bienes, derechos y libertades, no describe una sola y única manera de alcanzar dichos fines, pues en el momento de seleccionar entre diversos instrumentos racionales que permitan la consecución de dichos fines, lo más importante es que el medio que vaya a ser seleccionado, sea el idóneo para lograr dicho propósito dentro de un Estado social y democrático de derecho como es el colombiano.

No se exige un comportamiento específico, ni la adopción de un modelo o paradigma de administración de justicia, pues debe ser, ante todo, un instrumento, que permita lograr la salvaguarda de los derechos de los asociados, en tanto que el medio que se seleccione, resulte ser el adecuado para alcanzar dichos fines constitucionales.

En lo que se refiere a la protección judicial de los derechos de los asociados, la Constitución no exige que todos los delitos tengan que ser investigados al mismo tiempo, ni con la misma intensidad, es decir, que la Carta Política, no demanda que el deber de protección que recae sobre las autoridades públicas, debe cumplirse de una forma específica, todo lo contrario, 
lo más importante es que el modelo que se vaya a seleccionar sea apto para la consecución de dichos fines estatales, esto significa, que se trata de una análisis de medios a fines.

\subsubsection{El derecho a la igualdad}

El principio de igualdad se materializa en cuatro mandatos, que van a cargo del Estado y son los siguientes:

i) tratar de forma idéntica a ciudadanos que se hallen en iguales circunstancias; ii) tratar de forma diferente a destinatarios cuyas situaciones no compartan ningún elemento común; iii) un mandato de trato paritario a personas cuyas situaciones presenten similitudes y diferencias, siendo más relevantes aquéllas que éstas (trato igual a pesar de la diferencia); y iv) un mandato de trato diferenciado a destinatarios que se encuentren también en una posición, en parte similar y en parte diversa, pero cuyas diferencias sean más relevantes que las similitudes existentes (trato diferente a pesar de la similitud). (Barbosa \& Bernal, 2015, p.125)

Por otra parte, la jurisprudencia constitucional considera, que la igualdad ofrece una doble dimensión: objetiva y subjetiva; de acuerdo con la primera, se trata de un mandato de optimización dirigido al legislador y a la administración, según el cual, se deben proferir leyes y adoptar políticas públicas que garanticen un trato igual entre los ciudadanos; por otra parte, la dimensión subjetiva, determina que el ciudadano es titular del derecho a exigir un trato igualitario al momento de ejercer un derecho, como es el caso, del derecho a la administración de justicia.

El principio del derecho a la igualdad, ofrece dos manifestaciones que son complementarias y que son la igualdad ante la ley y la igualdad en la ley. De acuerdo con la primera, los ciudadanos deben recibir el mismo trato en la aplicación administrativo y judicial de la ley y de acuerdo con la segunda, el legislador se encuentra vinculado a dispensar el mismo trato a los asociados. 
En este orden de ideas, el derecho fundamental de acceso a la administración de justicia en condiciones de igualdad, le impone al Estado y a la Fiscalía General de la Nación, el deber de adoptar instrumentos de política criminal, que permitan establecer un trato diferente entre demandas ciudadanas de justicia distintas, puesto que no todos los delitos presentan el mismo impacto social, gravedad o relevancia, ni todas las reclamaciones de justicia se encuentran en la misma posición.

La implementación de unos criterios transparentes y democráticos de priorización de situaciones y casos, antes que vulnerar el derecho fundamental de acceso a la administración de justicia en condiciones de igualdad, configura un medio justificado e idóneo para garantizarlo, y el continuar brindando idéntica atención a peticiones de justicia diferentes, se configura como un desconocimiento del derecho a la igualdad.

\subsubsection{El derecho de acceso a la administración de justicia}

De conformidad con la jurisprudencia constitucional, el derecho de acceder a la justicia, establecido en el artículo 229 de la Carta Política, posee una significación bastante compleja, pues constituye la base fundamental del Estado Social de Derecho y contribuye a la realización material de los fines esenciales e inmediatos del Estado. Por otra parte, se configura como un derecho fundamental de aplicación inmediata, que forma parte del núcleo esencial del debido proceso y que implica lo siguiente:

i) la existencia en el ordenamiento jurídico, de diversos mecanismos - acciones y recursos , para la efectiva resolución de los conflictos; ii) la posibilidad de acción o de promoción de la actividad jurisdiccional, por parte de todo sujeto de ser parte en un proceso y de utilizar los instrumentos que allí se proporcionan para plantear sus pretensiones; iii) el derecho a que la actividad jurisdiccional concluya con una decisión de fondo en torno a las pretensiones que se hayan planteado, y que ésta se produzca dentro de un plazo razonable; iv) el derecho a que existan procedimientos adecuados, idóneos, y efectivos para la definición de la pretensiones y excepciones debatidas; v) el derecho a que los procesos se 
desarrollen en un término razonable, sin dilaciones injustificadas y con observación de las garantías del debido proceso. (Barbosa Castillo, G. y Bernal Pulido, 2015, p.126).

Por otra parte, la Corte Constitucional ha considerado que el derecho de acceso a la administración de justicia, como todo derecho fundamental, no es absoluto, tal y como se sostuvo en Sentencia C - 652 de 1997, reiterada en Sentencia C - 1195 de 2001, la cual determina lo siguiente:

(...) el derecho de acceso a la administración de justicia resultaría seriamente afectado en su núcleo esencial si, como lo anotó la Corte, "este pudiera concebirse como una posibilidad ilimitada, abierta a los ciudadanos sin condicionamientos de ninguna clase especial". Tal interpretación, evidentemente llevaría a la parálisis total del aparato encargado de administrar justicia, e implicaría per se la inobservancia de cierto derecho de los gobernados, en particular aquel que tienen las personas de obtener pronta y cumplida justicia (...). (Barbosa \& Bernal, 2015, p.127).

De conformidad con lo anterior y en los términos de la jurisprudencia constitucional, el derecho fundamental de acceso a la administración de justicia debe ser ejercido dentro de unos límites razonables, so pena de conducir a la "parálisis del aparato encargado de administrar justicia”.

Lo anterior significa, que la adopción de unos criterios de priorización, antes que desconocer el núcleo esencial derecho fundamental de acceso a la administración de justicia, constituyen un instrumento idóneo para su realización en condiciones de igualdad, es decir, que una atención diferenciada de las peticiones de administración de justicia, soportada sobre la aplicación de criterios razonables, tales como la calidad de víctima y del victimario, la gravedad de los hechos, la riqueza probatoria del caso, los patrones regionales de comisión de los delitos, entre otros, no constituyen un desconocimiento del derecho de acceso a la administración de justicia, pues en realidad lo que hacen es garantizarlo. 


\subsubsection{Ley 975 de 2005 y sus decretos reglamentarios}

La noción del término contexto, dentro de la política criminal de la Fiscalía General de la Nación, tiene como objetivo, llegar al final de un conflicto armado interno en nuestro país y lograr una paz a mediano plazo tal y como se establece en la Ley 1448 de 2011 y en el Documento CONPES 3712 del $1^{\circ}$, , de diciembre de 2011, para analizar lo anterior, se deben mirar los antecedentes que a continuación se presentan.

\subsubsection{De la ley 1448 de 1997 a la ley 1421 de 2010}

Dicho andamiaje político - jurídico, creado por la Ley 1448 de 1997, busca lograr acercamientos con los grupos insurgentes, dicha Ley ha sido actualizada y prorrogada en el tiempo hasta la Ley 1421 de 2010, donde se describe el significado de los grupos armados al margen de la Ley.

Lo anterior, tomando como base el Protocolo II de Ginebra, constituyéndose en un antecedente importante, para entender la palabra "contexto" desde el ámbito del Derecho Penal Internacional.

Finalmente, "La estructura de todo este marco normativo genera en Colombia temas como los relativos a indultos, amnistías, reconocimientos políticos para fines específicos, etc.”.

\subsection{La importancia de investigar, por medio del contexto, los crímenes de lesa humanidad perpetrados en Colombia}

La Fiscalía General de la Nación, busca configurar un esquema de actuación por medio del cual, se procure el uso racional de los recursos, a efectos de alcanzar los fines que justifican su existencia.

Para lograr lo anterior, la implementación del análisis de contexto, tanto para la justicia transicional como para la justicia ordinaria, es una estrategia de política criminal destinada a 
mejorar la eficiencia, en atención a la cantidad y gravedad de los hechos criminales existentes y a sus propias capacidades y recursos disponibles.

Todo esto, sin restarle importancia y transcendencia, al fin supremo de hacer efectivos los derechos de las víctimas, de la sociedad y del imputado, ya que los objetivos que busca la Fiscalía por medio de esta nueva estrategia de investigación penal y con la implementación del nuevo sistema de gestión de los criterios de priorización, apuntan a obtener resultados que van conformes con la realidad.

Por medio de la investigación en contexto se logra la persecución efectiva de los máximos responsables de la comisión de crímenes del sistema, que han sido perpetrados por aparatos organizados de poder, para conocer la verdad de lo sucedido, evitar su repetición y buscar la reparación integral de las víctimas, además se logra por medio de la investigación en contexto, la investigación y el desmantelamiento de organizaciones delictivas responsables de la comisión de múltiples delitos ordinarios.

En el caso de delitos que no hayan sido perpetrados por organizaciones delictivas, el sistema diseñado por parte de la Fiscalía General de la Nación, busca combatir patrones culturales discriminatorios y graves vulneraciones de los derechos fundamentales y enfocar de forma transparente, racional y controlada, la acción investigativa de la Fiscalía General de la Nación hacia la obtención de dichos objetivos.

Es importante destacar, que las herramientas metodológicas, que son utilizadas para la investigación en contexto, como son el análisis criminal, establece una nueva forma de ver el crimen, con gran amplitud cognitiva, y esto conlleva a que el análisis criminal deba ser interdisciplinario, pues solo de esta forma se logra una aproximación a la realidad en la cual se produce el delito y determinar su impacto individual y social.

Tanto la investigación como el análisis criminal, se deben adelantar por medio del empleo de diversas ciencias y disciplinas que faciliten el acceso a la verdad y que además logren servir de garantes de los derechos de los investigados, de las víctimas y de la sociedad, con la 
finalidad de recaudar y custodiar el material probatorio y la evidencia física para poder sustentar de esta forma la imputación correspondiente y reclamar las reparaciones debidas.

Por otra parte, también se debe utilizar la priorización, la cual, se define como un parámetro lógico para focalizar la acción investigativa hacia determinadas situaciones y casos, con el objetivo de ampliar el impacto de la actuación de la Fiscalía en el cumplimiento de sus finalidades y a aprovechar sus recursos.

Este es uno de los elementos más importantes de la Directiva, puesto que determina con mayor claridad, la novedad de la política criminal, destinada a alcanzar como fines la "seguridad ciudadana" y la respuesta efectiva para hacerle frente a la criminalidad organizada, "la legitimidad y eficacia en la administración de justicia”, a través del uso racional de los recursos y de la mejora en la administración de justicia y de la reducción de la impunidad; y de esta forma, "atender las exigencias de la sociedad civil".

Además, y de conformidad con lo preceptuado en la Directiva 002 de 25 de la Fiscalía General de la Nación, se establece que la investigación penal en contexto colabora dentro del proceso de investigación de la siguiente manera:

(i) encontrar relaciones entre diferentes casos para resolver conjunto de delitos; (ii) judicializar a los responsables teniendo en cuenta su participación en los hechos y el rol que cumplen en la estructura criminal para contribuir a su desmantelamiento; (iii)develar planes criminales; (iv)identificar modus operandi, practicas y patrones criminales ; $(v)$ emplear esquemas de doble imputación penal del derecho penal internacional; y (vi) a portar elementos a la reconstrucción de la verdad histórica, entre otras. (Colombia, Fiscalía General de la Nación,2015, Directiva 002, p.43) 
Finalmente, se exige tratar a la criminalidad desde una perspectiva de contexto, con la finalidad de enfrentarla cada vez de mejor forma debido a su gran complejidad como fenómeno, además, la priorización de los delitos por investigar tiene como objetivo, lograr una mayor eficacia en la desarticulación de la criminalidad organizada, e impedir que se sigan cometiendo violaciones graves y masivas de los derechos humanos. 


\section{Capítulo 2}

\section{Metodologías de investigación penal, con base en criterios de priorización, para crímenes de lesa humanidad desde el ámbito del \\ Derecho Internacional}

\subsection{La estrategia de selección y priorización desde el derecho internacional}

El operador jurídico que ha trabajado con la Ley de Justicia y Paz, en lo que conocemos como la Justicia Transicional, en el momento de aplicar sus normas, no ha ponderado de forma fehaciente, los derechos a la justicia y a la paz, ni tampoco se ha basado en la necesidad de optimizar los recursos disponibles, para obtener los mejores resultados en el menor tiempo posible, en lo concerniente a las investigaciones de crímenes de lesa humanidad, en un país que ha sido azotado por la violencia institucionalizada, con elevados índices de criminalidad y de impunidad, unido a la desconfianza en la administración de justicia debido a sus escasos resultados.

El proceso de Justicia y Paz en Colombia, como el mismo proceso que se llevó en la Habana, requiere necesariamente de nuevas estrategias de investigación, debido a que las que se han intentado hasta el momento, no han resultado ser favorables, por el círculo de impunidad que siempre ha rodeado a estos crímenes, ni han llenado las expectativas que la sociedad tenía en lo que respecta a su aplicación.

La Fiscalía General de la Nación, y en particular la Unidad Nacional de Fiscalías para la Justicia y la Paz, han considerado que se debe acusar por el conjunto total de delitos que haya cometido cada uno de los postulados por el Gobierno Nacional a la Ley de Justicia y Paz, porque de lo contrario, se estaría contrariando el Estatuto de Roma, y la Jurisprudencia de la Corte Interamericana de Derechos Humanos en relación con los artículos 8.1 y 25 de la Convención Americana de Derechos Humanos; y la ratio decidendi. (Forer \& López, 2011, p.234), del auto de segunda instancia de la Sala de Casación Penal de la Corte Suprema de Justicia del 28 de mayo de 2008, dentro del proceso contra Wilson Carrascal Salazar, pues de acuerdo a las fuentes del derecho, se deben realizar investigaciones completas e integrales en las cuales cada una de 
las victimas sienta que obtuvo lo fines de la Justicia Transicional, como son los derechos subjetivos a la verdad, a la justicia y a la reparación integral.

Esta postura para la Unidad Nacional de Fiscalías para la Justicia y Paz, sería la ideal, pero irreal por la alta complejidad que representan estos delitos, por el creciente y progresivo número de postulados y de víctimas de estos hechos, y por el número y clase de conductas punibles confesadas, que en la gran mayoría de los casos no obedecen a los parámetros de los Grupos Armados organizados al margen de la Ley, ni a hechos sistemáticos, ni generalizados, o a los hechos que se suceden en combate, sino que se presentan como hechos aislados de la política del grupo y que además, fueron planeados y realizados en diversas zonas del país.

Por otra parte, se debe resaltar la calidad de las víctimas, y la cantidad de compulsación de copias a la justicia ordinaria para investigar a servidores públicos, políticos, miembros de la fuerza pública y de la policía nacional; por tal razón, el proceso penal definido en la Ley de Justicia y Paz, se ha tornado lento y sin resultados verificables.

Es importante tener en cuenta, que los delitos cometidos por los Grupos Armados al margen de la Ley, considerados como delitos de sistema, se caracterizan por altos niveles de coordinación, complejidad, con estructuras de mando claramente definidas, las cuales, debido a su dinámica y a su historia de impunidad, no le permiten al Estado Colombiano a través de la Unidad Nacional de Fiscalías para la Justicia y Paz, investigar todos los delitos y a todos los autores de estos mismos hechos.

Por lo tanto, es absolutamente necesario, seleccionar tanto lo delitos como los autores de los mismos, lo cual, generaría una brecha de impunidad, porque algunos crímenes y perpetradores no serían sujetos de investigación dentro del marco del proceso de Justicia y Paz, debido a que sucedería todo lo contrario, de los casos que adelanta la Corte Penal Internacional o los Tribunales ad - hoc, donde los delitos que no son priorizados, para ser investigados, deben ser de conocimiento de la justicia nacional del país que ha sido afectada. 
En el caso de los delitos que no sean priorizados en Colombia, la Fiscalía General de la Nación, no tiene una instancia judicial a la cual remitir los casos que no sean objeto de selección, lo cual conlleva a una impunidad parcial, que es aceptada a nivel internacional, pues para Colombia que ha sido un país que ha padecido una violencia generalizada por muchos años, es imposible humana y técnicamente investigar todos los autores y todas la conductas criminales, además, existe el riesgo, de que las investigaciones y juicios nunca acaben (o por lo menos no antes de la muerte de los postulados, testigos o víctimas); lo cual, llevaría a una mayor impunidad.

A diferencia de lo establecido en la legislación penal colombiana, sí es posible realizar una selección y no juzgar penalmente algunas conductas punibles sin contradecir las obligaciones del Estado desde el derecho internacional, puesto que existen instrumentos judiciales alternativos para investigar los delitos no priorizados, y aun así, garantizar los derechos a la verdad, a la justicia y a la reparación.

Es decir, que siempre y cuando los crímenes internacionales y los autores sean juzgados y condenados, el Estado no violaría las obligaciones contraídas en los diferentes instrumentos internacionales, inclusive en algunos casos, una amnistía nacional aun para delitos que son considerados como crímenes internacionales (menos graves), sería admisible bajo el Estatuto de Roma.

Por otra parte, desde la perspectiva del Sistema Interamericano de Derechos Humanos, se considera que una amnistía condicionada para crímenes de menor gravedad, no violaría la Convención Americana de Derechos Humamos, cuando el deber de los Estados Partes de: “investigar, juzgar y sancionar se ha cumplido a través de instrumentos alternativos, porque la Corte no demanda explícitamente una persecución penal”. (Forer \& López, 2011, p.236).

Los instrumentos alternativos, podrían llegar a ser en algunos casos, las Comisiones de la Verdad, las cuales, tendrían el papel de investigar los casos que no hayan sido seleccionados, para brindar un escenario a los postulados como a las víctimas de estos hechos, para hallar la verdad de los hechos perpetrados en las zonas de conflicto. 
Dicha institución sería la encargada de otorgar una amnistía individual y condicionada siempre y cuando, los autores cumplan con las condiciones que se imponen, tales como confesar todos los delitos cometidos, reparar integralmente a las víctimas, mostrar arrepentimiento de los sucedido, no volver a delinquir, entre otros aspectos; por otra parte, la documentación y la publicación de las informaciones recibidas en el trabajo de la Comisión de la Verdad, pueden llegar a superar un pasado violento, lograr formas de reconciliación y garantizar la no repetición de los mismos hechos.

Por otra parte, se podría aplicar el principio de oportunidad, amnistías e indultos para los delitos de carácter político y que sean de menor gravedad, u otra clase de mecanismos para lograr llegar a la verdad y la reconstrucción de la memoria histórica, siempre que la conducta, no constituya un alto grado de reproche social y se respeten los derechos de las víctimas.

La estrategia de la Fiscalía General de la Nación, por medio de la cual, los operadores judiciales deben realizar una investigación integral en la cual, se investiguen todos los delitos y todos los autores, se basa en una defectuosa interpretación del artículo 18 de la Ley de Justicia y Paz, y del Auto de Segunda Instancia del 28 de Mayo de 2008 de la Sala de Casación Penal de la Corte Suprema de Justicia, contra alias "El Loro".

La investigación integral no significa investigar todos y cada uno de los hechos confesados, sino únicamente aquellos que se encuentren dentro del contexto de macro criminalidad de los Grupos Armados al Margen de la Ley, y dentro de este mismo proceso, se debe investigar la dinámica del sistema en que las conductas punibles se cometieron, los patrones de conducta de sus miembros, y las relaciones de mando y cooperación entre los actores armados, para elaborar un análisis exhaustivo de cada grupo y el mapeo general de sus diversas actividades, lo cual, ayudará a establecer si existió sistematicidad y concierto, para poder cometer los delitos bajo las políticas trazadas por parte de los superiores jerárquicos de cada Grupo Armado al Margen de la Ley.

La Corte Suprema de Justicia, en palabras de López Medina, determina lo siguiente: 
no exige que haya acusación y condena por todos los delitos cometidos; la Corte exige que los delitos presentados, según criterios razonablemente aplicados por el ente acusador, queden claramente enmarcados dentro de la criminalidad de sistema que el país y las víctimas tiene derecho a conocer. La Corte exige narrativas globales para cada delito imputado, no la imputación de todos los delitos. La Corte sabe que esto último es imposible. (Forer \& López, 2011, p.238).

Lo anterior quiere decir, que la Corte Suprema de Justicia, solo busca que el Estado investigue, juzgue y condene con penas adecuadas a los responsables de graves violaciones a los derechos humanos, de esta forma dentro del contexto nacional, existe la opción de diferenciar y tratar de forma diferente los distintos autores y crímenes sin salirse del marco legal en sentido amplio.

De alguna manera, tanto las Comisiones de la Verdad y Reconciliación que presentan una amnistía condicionada, pueden satisfacer las exigencias de las víctimas y de la sociedad y cerrar la "brecha de la impunidad", con el fin de establecer la estrategia de dividir y distribuir en diferentes tribunales de conocimiento, el juzgamiento de los delitos de acuerdo con la gravedad de los casos y la responsabilidad de los perpetradores, y este es un excelente ejemplo, para lograr la dinamización del proceso de investigación.

Con la enseñanza a nivel de los procesos en el ámbito internacional y de acuerdo a las particularidades del proceso colombiano, consideramos que la selección de casos es una estrategia útil de investigación y persecución penal, la cual puede implementarse por medio de criterios objetivos, subjetivos, y otros que son complementarios, con el propósito de tener casos de alta trascendencia y de alto impacto dentro de la sociedad.

Es importante, determinar los criterios para la selección de los casos, posteriormente, se deberá establecer una jerarquía de criterios para facilitar la priorización de los delitos seleccionados, puesto que la determinación clara y transparente de los criterios es crucial para la comprensión del proceso, la cual, no debería dejar ninguna duda acerca de la legitimidad, la honestidad y la independencia de influencias exteriores de la fiscalía. 
La política de selección de casos, parte del reconocimiento de las autoridades judiciales, ejecutivas, legislativas, de la imposibilidad de investigarlo todo y de la necesidad de visibilizar ante la comunidad nacional e internacional los casos más complejos, de mayor impacto social y paradigmáticos, que sirvan de ejemplo de la verdadera capacidad que tiene el Estado para enfrentar la criminalidad de sistema, y al mismo tiempo debe servir como agente disuasorio de conductas punibles que no se deban repetir en sociedad.

La selección de los casos, con base en un criterio subjetivo, tiene en cuenta la calidad de los victimarios como de sus víctimas, y se debe dejar bien claro, cuáles son los autores que dentro del aparato criminal se van a investigar, acusar y condenar, es decir, que se deben seleccionar a los autores que hacen parte de los mandos superiores, o de la cúpula de la organización criminal, o que estén vinculados al Estado directa o indirectamente, o que tengan capacidad de generar impunidad.

Se debe crear una tipología de los autores que en primer lugar se deberán investigar, definiéndolos de manera concreta, para que el operador judicial priorice dichas investigaciones, y lo mismo se debe hacer, en relación con las víctimas, es decir, que se debe establecer cuáles son las personas, los grupos o sujetos colectivos que se van a priorizar, porque pertenecen a un determinado grupo, por ejemplo, en el caso de que sean defensores de derecho humanos, operadores judiciales, representantes laborales o sindicales, testigos, periodistas, miembros de ONG, defensores públicos, indígenas, niños, mujeres, afrodescendientes, etc...

El criterio subjetivo, establece la lista de los delitos que de preferencia se cometen en la criminalidad de sistema, los cuales serán el centro de atención del operador judicial, en todas las etapas procesales. Esto significa, que se debe establecer el catálogo de los delitos que se deben investigar, para ello se debe contar con investigadores expertos en los delitos que hagan parte de esta lista para avanzar rápida y certeramente en las investigaciones. Por ejemplo, en el caso de que se vaya a investigar la criminalidad organizada, dentro de esta lista estarán los delitos de concierto para delinquir, uso ilegal de uniformes, comercialización de armas, etc..., además, se deberá definir, en qué consiste la criminalidad organizada, y sus características. 
Una vez establecidos los delitos seleccionados, se debe establecer clara y públicamente por parte del Director o Jefe del ente investigador el criterio que los priorizará, es decir, se debe establecer en el tiempo, el orden en que se deben investigar tales conductas, por otra parte, para la selección de casos, se deben tener en cuenta los criterios complementarios, como son la factibilidad, la necesidad, la viabilidad, el impacto social y político, y la riqueza didáctica.

En relación con el criterio de factibilidad, se evalúa la información de la cual se disponga de la conducta punible en relación con la probabilidad de encontrar la que haga falta, y para lograrlo, se deben tener en cuenta factores como el tiempo que ha transcurrido desde la comisión de la conducta y la investigación que se adelanta, con el objetivo de obtener alguna evidencia, testigos, agentes encubiertos, etc.

En relación con el criterio de necesidad, se evalúa la capacidad que tiene el Estado a través de la Fiscalía solo o con ayuda de otras entidades estatales o de la misma víctima, de llevar a cabo la investigación, para poder llegar a una condena.

El criterio de viabilidad, se relaciona con la capacidad económica, de cooperación y de logística para obtener pruebas suficientes para acusar y para condenar, es decir, se pretende obtener el máximo resultado posible, con el mínimo de recursos, y esto requiere invertir recursos humanos, de tiempo, despliegue territorial y recursos materiales.

En lo que respecta al criterio de relevancia o impacto social y político del hecho, se debe analizar que dado que no existen muchos recursos, se le debe dar privilegio a aquellos casos que tengan connotación social y que generen alta sensibilidad en la sociedad y el impacto necesario para demostrar la eficiencia y eficacia de la administración de justicia.

El criterio de riqueza didáctica, se relaciona con la capacidad que debe tener el caso que ha sido seleccionado de generar buenas prácticas de investigación, persecución, jurisprudencia, que promuevan principios y valores de justicia, ya que en base a todos ellos, se pueden proponer reformas en lo judicial y en lo legislativo para impedir la impunidad. 
Finalmente, los casos que hayan sido seleccionados por criterios objetivos, subjetivos y complementarios o por varios de ellos al mismo tiempo, deben ser orientados a casos de calidad o significativos, con valores técnicos e ilustrativos, se debe valorar además en abstracto, si el caso tiene riqueza y calidades mínimas que permitan un avance tanto en la doctrina y en la jurisprudencia, como en las técnicas de investigación; además, el caso priorizado, debe ser capaz de mostrarse como "modelo" o "caso tipo" de manera ilustrativa y ejemplarizante.

\subsection{La forma de construir los contextos en el derecho internacional}

Se debe tener presente, que los crímenes de lesa humanidad, a diferencia de los delitos comunes, son perpetrados de manera masiva o sistemática, por medio de organizaciones ya sean estatales o particulares, y de lo anterior, se colige que la responsabilidad penal es individual, y en cada caso concreto, la misma se debe determinar, en relación a determinados hechos imputados al acusado, además, dichas conductas debe ser contextualizadas.

Todas esas conductas, deben ser tomadas en cuenta, no de manera aislada, sino que las mismas deben ser ubicadas en determinado espacio geográfico, durante un época específica, y vinculadas con la actividad de la organización criminal, es decir, con el modus operandi, con la estructura, y con los demás aspectos, que caracterizan a un grupo o a una organización, llámese legal o ilegal.

Es decir, que en las investigaciones para los crímenes de lesa humanidad, se debe tener presente el proceso de contextualización de estos mismos delitos que son imputados a un determinado acusado, donde el proceso de investigación se desarrolla de lo general a lo particular.

Para investigar crímenes de alto impacto, se deben construir grandes líneas, la cuales, deben tener relación con los protagonistas del conflicto, teniendo en cuenta, su estructura, el número, el interés, las estrategias, el modus operandi, los principales hechos delictivos perpetrados, etcétera, que fueron realizados en una determinada región de un país y en cierta época. 
Todo termina con el examen de la figura del acusado y con los actos concretos que al mismo se le imputan, pero no se profundiza en los detalles del accionar del grupo delictivo; además, un determinado contexto es común emplearlo, para una técnica de agilización y de descongestión judicial.

\subsection{La política de priorización en los Tribunales Penales Internacionales}

La jurisdicciones penales internacionales, siempre han tenido una técnica de priorización implícita en el ejercicio de su jurisdicción, como ejemplo de lo anterior, podemos citar el articulo 1 (1) del Estatuto de la Corte Especial para Sierra Leona, el cual determina, la posibilidad de investigar únicamente a las personas que tienen "la mayor responsabilidad" (Colombia, Fiscalía General de la Nación, 2012, Directiva 0001, p.117), en la comisión de delitos, que se encuentren bajo su jurisdicción.

El Acuerdo para el Establecimiento de las Cortes Extraordinarias de Cambodia, contempla el ejercicio de jurisdicción sobre "altos funcionarios de la Kampuchea Democrática y aquellos con mayor responsabilidad" (Colombia, Fiscalía General de la Nación, 2012, Directiva 0001, p.117), por los crímenes que fueron cometidos entre 1975 y 1979.

El artículo 1 del Estatuto del Tribunal Penal Internacional para la antigua Yugoslavia, extiende su jurisdicción a las "personas responsables de violaciones graves de derecho internacional humanitario" (Colombia, Fiscalía General de la Nación, 2012, Directiva 0001, p.117), y que de acuerdo a la interpretación del Primer Presidente del Tribunal, es una priorización de los casos más graves cometidos por los líderes del conflicto.

Por otra parte, la jurisdicción de la Corte Penal Internacional, se basa igualmente en criterios de priorización, por ejemplo, el artículo 17 del Estatuto de Roma de la Corte Penal Internacional, establece unos límites de admisibilidad de casos ante la Corte y de tal forma, solamente activa su jurisdicción cuando el Estado no quiera o no pueda investigar y sancionar a las personas que hayan cometidos delitos bajo su jurisdicción. 
La característica del hecho delictivo debe ser lo suficientemente grave, que es una salvaguardia que va en perfecta consonancia con los instrumentos de derechos humanos, y de la misma forma, el artículo $1^{\circ}$., del Estatuto de Roma, dispone el ejercicio de jurisdicción "sobre personas respecto de los crímenes más graves de trascendencia internacional de conformidad con el Estatuto de Roma y tendrá carácter complementario de las jurisdicciones penales nacionales".

De la misma forma el artículo 5 (1) que son los "Crímenes de competencia de la Corte", determina que "la competencia de la Corte se limitará a los crímenes más graves de trascendencia para la comunidad internacional en su conjunto". (Colombia, Fiscalía General de la Nación, 2012, Directiva 0001, p.118).

Desde la Creación de la Corte Penal Internacional, se recibió con gran preocupación su capacidad de obstaculizar los procesos nacionales de reconciliación, y desde un principio se ha intentado armonizar la existencia de procesos nacionales de transición, que incluyen exoneraciones parciales de responsabilidad.

En lo que respecta a la lucha contra la impunidad de la Corte Penal Internacional, en la actualidad el Estatuto de Roma, permite la aplicación de amnistías parciales, siempre que los procedimientos de justicia nacional sean genuinos y no generen impunidad manifiesta. Es considerable en cierto sentido, un programa de comisiones de verdad que incluya amnistías internacionales para victimarios de menor jerarquía, siempre y cuando se investigue y juzgue a las personas más responsables, y que sea compatible con la Corte Penal Internacional.

De todas maneras, el Estatuto de Roma, posee las herramientas que se consideran necesarias para reconocer los procesos nacionales que incluyan exoneraciones parciales de responsabilidad; por ejemplo, el artículo 53 (1) (c) del Estatuto de Roma, permite que el Fiscal archive una cuando en su criterio "existen razones sustanciales para creer que, aun teniendo en cuenta la gravedad del crimen y los intereses de las víctimas, una investigación no redundaría en interés de la justicia". 
La segunda posibilidad, la encontramos en el artículo 17 (1) (b) del Estatuto de Roma, en el cual, se determina un margen de discrecionalidad mucho menor al que tiene el Fiscal bajo el artículo 53 (1) (c), pues en este supuesto, el procedimiento transicional doméstico se equipara a un procedimiento judicial común y se busca apelar a la complementariedad de la Corte, con el fin de satisfacer la obligación de investigación y sanción doméstica según el procedimiento híbrido interno, y esto implica tener que demostrar de que se trata de una auténtica investigación que concluye con una decisión de no sancionar penalmente, pero por razones distintas a la incapacidad y con una razón genuina para poder hacerlo.

La tercera posibilidad emana, del artículo 16 del Estatuto de Roma, según el cual, el Consejo de Seguridad de las Naciones Unidas puede detener una investigación mediante la adopción de una resolución bajo el Capítulo VII de la Carta de las Naciones Unidas, esta es una decisión de competencia exclusiva del Consejo de Seguridad, quien tendría que tener el suficiente interés sobre la situación para intervenir ante la Corte.

De lo anterior, se concluye, que las jurisdicciones penales internacionales incorporan dentro de sus propios términos de referencia una priorización de los casos que pueden ser sometidos a su jurisdicción, y que se trata de las personas más responsables por la comisión de los delitos más graves.

Todos los individuos ubicados en los escalafones más bajos dentro de una empresa criminal conjunta, o que no hayan cometido los crímenes más graves, están por fuera de la órbita de una jurisdicción penal internacional, además, el Estatuto de Roma de la Corte Penal Internacional es perfectamente compatible con los procesos de justicia transicional en las jurisdicciones domésticas, donde existe una exoneración de carácter parcial de la responsabilidad.

Por su parte, el fiscal de la Corte como el Consejo de Seguridad, tiene la facultad para conceder un margen de libertad al Estado en sus procedimientos domésticos, inclusive cuando no hay una investigación y sanción total de los crímenes cometidos en conflicto. 
Todo lo anterior significa, que se trata de una regulación jurídica, que no es muy distinta, en sus limitaciones y permisos, a los instrumentos de derecho internacional de los derechos humanos, y a que nada en ellos impide una priorización de casos por parte de la justicia doméstica, siempre y cuando no se trate de una exoneración de responsabilidad general y absoluta.

\subsection{Las formas de investigación de los crímenes de lesa humanidad, en los Tribunales Penales Internacionales}

La investigación para crímenes internacionales, bien sea por medio de instancias penales internas o por medio de los Tribunales Internacionales, se caracteriza por varios elementos, que de acuerdo con Ramelli (2011), serían los siguientes:

1) Elevado número de víctimas y de victimarios;2) dificultad para demostrar su carácter masivo o sistemático; 3) destrucción de pruebas documentales y asesinato o intimidación de testigos y de funcionarios judiciales; 4) recolección de evidencia en el terreno; y 5) escasez de recursos económicos.(p.297)

Así mismo, la forma de investigación para esta gran diversidad de delitos, de conformidad con Ramelli (2011), se caracteriza, por desarrollar los siguientes elementos “1) Diseñar una estrategia global de investigación; y 2) adecuar una estructura burocrática adecuada, a efectos de evitar la dispersión de esfuerzos y recursos”. (p.297).

Lo anterior significa, que las formas y labores de investigación para estos crímenes de carácter internacional, no debe seguir los parámetros que son igualmente aceptados para los casos de los delitos comunes, debido a que son delitos que por sus altos índices de gravedad y por su misma naturaleza, requieren ser investigados de manera general. 


\subsubsection{La forma de investigación para los crímenes de lesa humanidad, en el Tribunal Penal Internacional para la antigua Yugoslavia}

Por medio de la Resolución 827 del 25 de mayo de 1993, el Consejo de Seguridad de la Organización de las Naciones Unidas, fue la entidad encargada de crear el Tribunal Penal Internacional para la antigua Yugoslavia, órgano encargado de "juzgar a los presuntos responsables de violaciones del derecho internacional humanitario cometidas a partir de 1991 en el territorio de la antigua Yugoslavia, según las disposiciones del presente estatuto”.

En la práctica dicho Tribunal ha tenido que encargarse de la investigación la comisión de los delitos de genocidio, de guerra y de lesa humanidad, que fueron perpetrados en el curso de los hechos más complejos y sangrientos que se hayan sucedido en Europa después de la Segunda Guerra Mundial, los cuales, han dejado más de 3. 000.000 muertos.

La guerra en Yugoslavia ha comprendido una serie de conflictos armados de carácter interno, internacionales y mixtos, que tuvieron su lugar en dicho territorio desde 1991 hasta el año 2001, esto quiere decir, que el Tribunal Penal Internacional para la Antigua Yugoslavia tiene competencia, para investigar lo sucedido durante:

1) la corta guerra de independencia de Eslovenia (1991); 2) el conflicto armado por la independencia de Croacia (1991 - 1995); 3) la guerra en Bosnia - Herzegovina (1992 1995); y 4) los hechos ocurridos en la provincia serbia de Kosovo (1998 - 1999).

Ante la gran demanda de crímenes internacionales que se debían investigar, y por el inmenso volumen de información recolectada, la Fiscalía del mismo Tribunal, decidió crear un Equipo de Orientación Estratégica, conformado por quince funcionarios, repartidos en cuatro subunidades, que de acuerdo con Ramelli (2011), son las siguientes:

1) El grupo de análisis de información, encargado de difundir aquélla entre las otras unidades administrativas de la Fiscalía; 2) el grupo de estrategia, responsable de mantener al tanto al jefe de investigaciones sobre el avance de éstas, proponer nuevas 
investigaciones y diseñar una estrategia global a seguir; 3) el grupo de preparación de investigaciones, encargado de adecuar el terreno para los nuevos equipos de investigadores y actuar en caso de urgencia; y 4) el grupo de proyectos especiales, encargado de elaborar la cronología de los hechos en la antigua Yugoslavia, recolectar testimonios y aclarar el sistema jurídico vigente en el país.(p.298). (Ramelli, 2011, p.298).

De igual forma en sus primeros años de funcionamiento, dado que la legitimidad del Tribunal Penal Internacional para la Antigua Yugoslavia no habían sido reconocido por todos los actores del conflicto armado que operaban en la región, y teniendo en cuenta que la misma no había cesado, la oficina del fiscal decidió poner en marcha una estrategia de investigación piramidal, lo cual en palabras de Ramelli (2011), significó que se tenía que partir de lo siguiente:

1) Los elementos de prueba disponibles; y 2) el examen del comportamiento de los autores de rango inferior en la respectiva organización criminal, quienes directamente habían perpetrado los crímenes o los habían ordenado. Se trataba, en consecuencia, de identificar a los autores materiales de los delitos mediante los testimonios suministrados por sus víctimas (p. 298).

Una vez recaudaros los materiales probatorios, en relación con los autores materiales de los hechos, los investigadores comenzaron a ascender dentro de la pirámide de la organización, a efectos de hallar a los máximos responsables de dichos crímenes, es decir a quienes los ordenaron, planificaron, financiaron o facilitaron. Tal labor será dispendiosa, por cuanto será necesario demostrar la existencia de un vínculo jurídico y de facto, entre las personas ubicadas en la cumbre de la organización y los crímenes perpetrados; para lograr lo anterior, será necesario acudir a pruebas documentales y testimoniales, las cuales, deben evidenciar la estructura y el funcionamiento de la organización, la cadena de mando, el establecimiento de responsabilidades al interior de la misma organización, y la construcción de indicios, etc. 
En lo referente a la estrategia de investigación, la Fiscalía del Tribunal Penal Internacional, aplica según su ICTY, el cual fuera publicado en 2009, unos criterios específicos para seleccionar a los "blancos de investigación":

Cualquier conflicto armado involucra grave actividad criminal como aquella que compromete a un amplio número de víctimas, testigos y perpetradores, no siendo posible ni practico investigar todos los crímenes o a todos los potenciales responsables. Se debe seleccionar a quien investigar, y tal decisión debe ser orientada por dos factores: el mandato de la autoridad judicial y la disponibilidad de la evidencia. Un mandato claro permite rápidamente desarrollar una estrategia investigativa, y a su vez, permite recolectar y organizar evidencia para casos particulares.

No se puede esperar, sin embargo, que los casos más difíciles o relevantes pueden ser preparados de primeros. Una unidad de un tribunal internacional para crímenes de guerra, recientemente establecida, va a contar con una comprensión muy pobre acerca de la complejidad de los hechos que debe confrontar. De allí que un entendimiento más completo sólo se alcanzará mediante conocimientos especiales, labores de investigación y dictámenes técnicos. Mientras una comprensión global acerca de los más graves crímenes pueda alcanzarse, en las primeras etapas investigativas se requerirán varios meses para diseñar un "cuadro" acerca de las estructuras de comando y las funciones desempeñadas por líderes de la organización.

Debido a que toda investigación requiere pruebas acerca de la responsabilidad penal individual, los fiscales e investigadores deben cuidarse de imputar responsabilidades colectivas para todos los miembros del grupo. Sin embargo, pueden existir situaciones en las cuales resulte razonable para una investigación apuntar hacia un líder en concreto, y concentrar los recursos en el examen de la estructura de mando que vincule a ese individuo con un crimen específico. No obstante lo anterior, los mejores resultados se pueden obtener combinando aproximaciones top - down (de arriba hacia abajo) y bottom - up (de abajo hacia arriba). Especialmente en las primeras etapas de investigación, fiscales e investigadores deben tener una mente abierta acerca de la responsabilidad de los 
individuos, y estar preparados para considerar evidencia contraria que altere el curso de la investigación, y evitar focalizarse simplemente en construir un caso contra un individuo por cuanto el descubrimiento temprano de algunas evidencias apuntaban a inculparlo. (Ramelli, 2011, p.299).

En lo que respecta a las preguntas de ¿qué investigar? y a ¿a quién investigar?, dentro del Manual del Tribunal Penal Internacional para la Antigua Yugoslavia, se admite que "los investigadores deben hacer elecciones" al momento de seleccionar los "blancos", tomando como base las siguientes directrices:

1. La gravedad de los crímenes, el número de víctimas, la duración de las ofensas y el grado de destrucción.

2. El papel del investigado, es especialmente su posición en la jerarquía política o militar; la extensión de su autoridad y su alegada participación en los crímenes bajo investigación.

3. Si las personas y los crímenes investigados fueron excepcionalmente notorios, incluso si la persona no contaba con una posición formal dentro de la jerarquía. (Ramelli, 2011, p.300).

Aparte de dichas directrices, se pueden considerar otra diferentes de orden práctico en el momento de iniciar la investigación, dichas consideraciones pueden incluir factores como posibilidades de tención y de contar con la evidencia necesaria, de forma general no serán investigadas personas que cuenten con un alto rango dentro de las organizaciones criminales, así tampoco como crímenes que sean considerados como incidentes aislados, los cuales, serán dejados para el conocimiento de autoridades locales.

El Consejo de Seguridad del Tribunal Penal Internacional para la Antigua Yugoslavia, consideró que este mismo debe concentrar sus investigaciones en los más antiguos líderes, quienes son sospechosos de ser los máximos responsables de crímenes que son de competencia del Tribunal Penal para la Antigua Yugoslavia. El mismo Tribunal, espera poder transferir otros casos que comprometen a individuos con bajo nivel de responsabilidad hacia las jurisdicciones nacionales competentes. 
La estrategia de investigación por parte del Tribunal Penal Internacional debe ser constantemente revisada, debido a que de acuerdo con Ramelli (2011), el Manual de Practicas del Tribunal Penal Internacional para la antigua Yugoslavia, determina lo siguiente:

1) debe existir un estrategia global de investigación que oriente todos los trabajos desarrollados por la Fiscalía; 2) la justicia penal internacional no pretende, ni tampoco podría hacerlo, encausar y sancionar a todos los responsables de la comisión de crímenes de su competencia; de allí la necesidad de establecer prioridades y seleccionar "blancos de investigación"; 3) una estrategia a seguir en las investigaciones por crímenes de lesa humanidad consiste en iniciar por la individualización de los perpetradores directos y, poco apoco, ir subiendo en la pirámide de la organización criminal; 4) la investigación de crímenes internacionales comporta adecuar estructuras burocráticas especializadas donde la información fluya entre sus integrantes; 5) resulta recomendable contar con unos criterios objetivos o directrices que permitan seleccionar qué y a quién investigar; y 6), aunque no menos importante, la "verdad" se va construyendo paso a paso, sin que exija llegar a ella o pretender agotarla mediante un único caso, por más emblemático que éste sea. (Ramelli, 2011, p.300).

Esta forma de investigación la podemos ver en el caso de Justicia y Paz, Ley 975 de 2005, por medio de la cual, se ha diseñado una estrategia de investigación, la cual, selecciona los casos para imputar, y así como a los postulados, los cuales, sirven para la visibilizarían de los "patrones de victimización".

Esto significa que las investigaciones sobre macro criminalidad, no se agotan con la simple enunciación de hechos delictivos aislados, sino que la misma debe orientarse a develar los motivos, las razones, y las relaciones existentes entre los diversos crímenes que se están investigando.

De esta manera, se propone el empleo de la figura de las imputaciones parciales, con base en los siguientes lineamientos: 
Como criterios de orientación para la decisión sobre adecuación de la imputación podrían servir el contexto o nexo temporal, territorial, material o personal, entre los hechos delictivos. En relación con el contexto territorial, se refiere a hechos que se caracterizan por su ocurrencia en una región determinada del país. El nexo material se refiere a los tipos de victimización, por ejemplo, los mal llamados casos de limpieza social, que han sido uno de los métodos utilizados por los grupos paramilitares durante su dominio de ciertas regiones y ejercicio de control sobre las actividades de la población civil. El nexo personal se refiere a la unificación de procesos contra varias personas desmovilizadas cuyo accionar muestra características similares o parecidas. (Ramelli, 2011, p.301).

Una vez que se ha diseñado la estrategia global de investigación, la justicia penal internacional ha determinado ciertos parámetros para adelantar investigaciones concretas, mediante el "programa metodológico", de esta forma, la investigación para los crímenes internacionales, requiere de la conformación de equipos multidisciplinarios, conformados por diversos especialistas, tales como investigadores con experiencia en policía judicial, analistas militares y políticos, historiadores, especialistas en demografía, forenses, y traductores, siendo esencial, que "todos en el grupo de investigadores aprendan entre sí, resultando fundamental que cada uno comprenda la estructura legal del caso y los requerimientos probatorios".

\subsubsection{La forma de investigación para los crímenes de lesa humanidad, en la Corte Penal Internacional}

A diferencia de los Tribunales Penales Internacionales ad hoc, los cuales, se crearon para investigar países concretos (la antigua Yugoslavia y Ruanda), la Corte Penal Internacional cuenta con una amplia competencia geográfica, la cual, ha sido particularmente extendida, debido a que al 21 de julio de 2009, 110 Estados son partes en el Estatuto de Roma, entre ellos: 30 africanos; 14 asiáticos; 17 europeos orientales; 24 latinoamericanos y del Caribe; y 25 lo conforman el grupo de países de Europa Occidental y otros Estados.

De acuerdo con lo anterior, el ámbito de competencia de la Corte Penal Internacional y de los Tribunales Penales Internacionales, que fueran creados por el Consejo de Seguridad, son 
equiparables, exceptuando al crimen de agresión previsto en el Estatuto de Roma y desarrollado en la Conferencia de Kampala.

En relación con las preguntas de ¿qué investigar? y ¿a quienes investigar?, la Corte Penal Internacional, cuenta con otra particularidad, en relación con las vías que dispone para que una situación llegue a su conocimiento, que de acuerdo a Ramelli (2011), serían las siguientes:

1) remisión del Consejo de Seguridad; 2) remisión de un Estado parte; y 3) actuación oficiosa del fiscal. De allí que en cierta forma, la decisión de dónde investigar no es monopolio de la Fiscalía de la Corte Penal Internacional. (p.306)

Hasta el momento actual solamente tres Estados, han remitido sus respectivas actuaciones a la Fiscalía de la Corte Penal Internacional, que son Uganda, República Democrática del Congo y República Centroafricana, por otra parte, el Consejo de Seguridad remitió la situación de Sudán y el fiscal abrió una investigación sobre Kenia.

De igual forma la Oficina del Fiscal efectúa un análisis preliminar en varios países y territorios tales como Chad, Afganistán, Georgia, Palestina y Colombia. En lo referente a la estrategia de investigación, el día $1^{\circ}$., de febrero de 2010, se publicó el texto Prosecutorial Strategy 2009 - 2012, documento del cual, se presentan los siguientes apartados.

\subsubsection{Focalización de investigaciones y acusaciones}

El Estatuto de Roma limita la Jurisdicción de la Corte a los crímenes de mayor gravedad, los cuales, afectan a toda la comunidad internacional y requieren que la oficina tome en cuenta la gravedad del crimen, al momento de decidir acerca de iniciar o de no iniciar las investigaciones.

De conformidad con este esquema estatutario, la Oficina consolidó una política de investigaciones y acusaciones que apunta hacia aquellos que detentan las mayores responsabilidades por la comisión de los crímenes más graves, basados en la evidencia que resulte en el curso de las investigaciones. Así, la Oficina acusará a aquellos ubicados en 
los niveles más elevados en la escala de responsabilidades, incluso aquellos que ordenaron, financiaron o de alguna otra forma organizaron los mencionados crímenes (...)

Una política focalizada en las investigaciones también significa que los casos ubicados dentro de una "situación" serán seleccionados de conformidad con su gravedad, tomando en cuenta factores tales como la escala, naturaleza, forma de comisión e impacto de los crímenes. Sólo un número limitado de casos serán seleccionados. Aquello le permitirá a la Oficina llevar a cabo investigaciones breves; limitar el número de personas puestas en peligro por su interacción con la Oficina, así como llevar a cabo juicios cortos que apunten a demostrar el grado de victimización. Mientras el mandato de la Oficina no incluya la producción de un registro histórico de un determinado conflicto, los casos serán seleccionados a efectos de contar con un muestreo que refleje los crímenes más graves y los principales tipos de victimización. (Ramelli, 2011, p.308).

En su parte IV, que habla de la "Evaluación", el plan estratégico del Corte Penal Internacional determina lo siguiente, de acuerdo a Ramelli (2011):

La Oficina participará en el trabajo de la Corte para crear unos indicadores. Medir la efectividad de la Oficina ayuda a poner fin a la impunidad y contribuye en la prevención de los crímenes bajo la jurisdicción de la Corte, tarea compleja que requiere una evolución completa de todo el sistema de Roma.

Con el principio de complementariedad, gran parte del trabajo encaminado a alcanzar los fines del estatuto será desarrollado por las jurisdicciones internas alrededor del mundo. Así, el número de casos que lleguen a la Corte no serán tomados como una medida positiva de eficacia. Verdaderas investigaciones y acusaciones de graves crímenes en los ámbitos ilustrarán el éxito del funcionamiento del sistema de Roma. (p.308)

Lo anterior permite inferir, que así como el Tribunal Penal Internacional posee una estrategia para investigar crímenes de alto impacto, así mismo la Corte Penal Internacional 
también tiene diseñada una estrategia investigativa, la cual, apunta a la persecución de los máximos responsables de la comisión de crímenes internacionales.

Dicha estrategia propende, por la selectividad en las investigaciones, de tal forma que la mayor parte de las investigaciones serán llevadas por los mismos Estados. El umbral para determinar la gravedad previsto en el Estatuto de Roma, impide abrir un caso en la Corte Penal Internacional contra personas de posición jerárquica baja o media, como fue el caso que sostuvo la Sala de Cuestiones Preliminares I, al negar la expedición de una orden de arresto en contra de Bosco Ntaganda.

\subsubsection{La forma de investigación penal en contexto, en el Sistema Interamericano de Derechos Humanos}

Desde el ámbito de análisis de los derechos humanos y desde el derecho internacional de los derechos humanos, dentro del Sistema Interamericano de Derechos Humanos, el tema del contexto, se ha presentado dentro de la Jurisprudencia de la Corte Interamericana de Derechos Humanos, como una forma especial de análisis de la situación, para determinar la responsabilidad del Estado dentro de hechos violatorios de las obligaciones de la Convención Americana.

La primera forma en la cual, el derecho internacional de los derechos humanos, ha desarrollado el contexto es por medio de un acercamiento a la práctica jurisprudencial de los tribunales de derechos humanos, y como no existen estudios sobre la materia, se debe acudir a las sentencias de la Corte Interamericana de Derechos Humanos, utilizando algunas referencias que en torno al tema del contexto, se han desarrollado en Colombia.

Por medio de la primera sentencia de fondo, la Corte Interamericana presenta un modelo probatorio flexible, que forma parte del sistema jurídico internacional de reparación, en el cual, la prueba sobre la existencia de una situación sistemática de violación de los derechos humanos es aceptada por parte de la misma Corte, con la finalidad de establecer un indicio útil para 
construir el convencimiento del juez respecto de la comisión de un hecho, que es violatorio de los derechos humanos y del derecho internacional de los derecho humanos.

En términos generales, el contexto tiene la siguiente finalidad:

dimensionar las violaciones y condicionar la responsabilidad internacional del Estado en relación con sus obligaciones generales, y se construye en una forma de reparación para las víctimas, así como de preservación de la memoria histórica de los hechos para evitar su repetición. (Barbosa \& Bernal, 2015, p.308)

En este sentido el contexto es utilizado principalmente para:

a) probar una violación; b) determinar la responsabilidad internacional del Estado; c) determinar la razonabilidad de una restricción de derechos; d) determinar un patrón sistemático de violaciones; e) facilitar la comprensión del caso; f) determinar la existencia de un crimen de lesa humanidad; g) mostrar una problemática específica, y h) mostrar una problemática en agravio de un grupo o actividad. (Barbosa \& Bernal, 2015, p.308)

\subsubsection{El contexto como prueba de violación de los derechos humanos}

En lo referente al uso de la investigación como mecanismo para probar una violación hacia los derechos humanos, la Corte Interamericana se ha pronunciado al respecto en las tres primeras sentencias proferidas en los casos Velásquez Rodríguez, Godínez Cruz, y Fairén Garbi y Solís, todas contra Honduras, en las cuales, se trata el tema de las desapariciones forzadas cometidas bajo el marco de una violencia generalizada en el país y bajo el amparo de una serie de normas nacionales de persecución en contra de la oposición, que desbordan los límites del derecho al debido proceso.

Dentro de los casos en mención, la Corte establece su estándar probatorio y acepta como válidos, el estudio del contexto que le presenta la Comisión respecto de la existencia de una situación sistemática y generalizada de desapariciones forzadas, para poder construir el acervo probatorio de los casos en estudio mencionados en dichas sentencias. 
En el caso Velásquez Rodríguez, vs, Honduras del 29 de julio de 1988, que es la primera sentencia de fondo de la Corte Interamericana de Derechos Humanos, se narra la situación de contexto y se explica la sistematización de los delitos de desapariciones forzadas en Honduras; en ésta sentencia la Corte presenta las reglas de valoración de la prueba y sobre la flexibilidad que puede existir dentro de la misma, habida cuenta de la naturaleza del Tribunal y de la justicia que se debe impartir.

La Corte Interamericana explica además, que a diferencia de los tribunales internos y de la Justicia Penal, ella puede utilizar medios indiciarios para establecer la responsabilidad del Estado, puesto que sería ilógico hacer recaer en la victima una carga probatoria desproporcionada, pues lo que se busca es darle una protección a sus derechos conculcados, ya que el Estado no goza de una presunción de inocencia, la cual debe ser desvirtuada por la víctima, de la siguiente manera:

En efecto, la protección internacional de los derechos humanos no debe confundirse con la justicia penal. Los Estados no comparecen ante la Corte como sujetos de acción penal. El Derecho internacional de los derechos humanos no tiene por objeto imponer penas a las personas culpables de sus violaciones, sino amparar a las víctimas y disponer la reparación de los daños que les hayan sido causados por los Estados responsables de tales acciones. (Barbosa \& Bernal, 2015, p.39).

A diferencia del Derecho penal interno, en los procesos sobre violaciones de derechos humanos, la defensa del Estado no puede descansar sobre la imposibilidad del demandante de allegar pruebas que, en muchos casos, no pueden obtenerse sin la cooperación del Estado. (Barbosa \& Bernal, 2015, p.309)

En este sentido, la Corte deja claro que el uso que se hace del contexto como medio probatorio, es propio del principio de flexibilidad al que como tribunal internacional puede recurrir, puesto que no se trata de un proceso interno y menos de un proceso penal, pues no responde a las exigencias probatorias de éstos procesos. 
La Corte, da por entendido que los estándares interamericanos no son compatibles con los estándares probatorios que se exigen por el debido proceso penal, y que su intención no es la de crear prácticas aplicables a los procesos internos, las cuales, tienen unos objetos y unas exigencias totalmente distintas.

Esta posición es coherente con los principios del derecho penal, y con el derecho al debido proceso, ya que la naturaleza de los procedimientos por responsabilidad penal internacional, es totalmente diferente a la del derecho penal interno y al aplicar las mismas fórmulas en ambos casos es contraria a su objetivo y finalidad.

\subsubsection{El contexto como determinante de patrones sistemáticos}

En los casos anteriores, se utilizó la estrategia del uso del contexto, por parte de la Corte Interamericana para establecer un patrón sistemático de violaciones a los derechos humanos, que facilitara la prueba sobre el hecho concreto. En la sentencia de Velásquez Rodríguez, la Corte estableció un método para acreditar la desaparición forzada de Manfredo Velásquez, el cual, consiste en lo siguiente: “i) probar la existencia de una práctica sistemática de desapariciones forzadas con un mismo patrón, cumplida o tolerada por las autoridades del Estado, y ii) encuadrar la desaparición de la víctima en dicho patrón”. (Barbosa \& Bernal, 2015, p.310).

En este caso, el contexto se limitó al desarrollo de los elementos constitutivos del patrón de desaparición forzada, sin que se entrara a considerar los antecedentes políticos o sociales de Honduras, es decir, la Corte Interamericana, buscó establecer un patrón sistemático de desapariciones forzadas, como medio de prueba para inferir la desaparición de la víctima.

En dichas Sentencias, la Corte utilizó el término "modus operandi", como un criterio de análisis para determinar si efectivamente existía la desaparición forzada y de esta forma explicó como actuaban los órganos militares en Honduras y se configuraban en ciertos elementos comunes en los cuales, se utilizaban uniformes y el uso de paneles blancos, teniendo en cuenta que días antes existían unas entrevistas por parte de los organismos del Estado, para que posteriormente se produjera éste delito. 
Posteriormente, los hechos que se pueden contextualizar, han adquirido mayor importancia en las sentencias, lo que ha permitido determinar patrones sistemáticos de violaciones, por ejemplo tenemos el caso de la sentencia Mack Chang vs, Guatemala (2003), dentro de contextos políticos y sociales más amplios que explican la existencia de esos mismos patrones de macro criminalidad.

Durante los nueve años posteriores, al jurisprudencia de la Corte Interamericana no se pronunció al respecto, pues se trataba de hechos aislados que tenían un marco factico específico, como en el caso Neira Alegría Vs. Perú (1995), por hechos ocurridos en el amotinamiento en una cárcel, posteriormente, en el caso Garrido y Baigorria vs. Argentina (1998) el allanamiento del Estado a las pretensiones, no permitió un desarrollo del análisis probatorio.

Solo hasta 1997, en los casos Loayza Tamayo y Castillo Páez, dentro del marco del conflicto peruano, la Corte reitera la flexibilidad probatoria con la cual cuenta, y luego, en 1998, en el caso Blake vs. Guatemala, la Corte retoma el análisis del contexto como medio probatorio.

Se cita a continuación, partes de la sentencia del caso Blake:

Como ha señalado la Corte, los criterios de apreciación de la prueba ante un tribunal internacional de derechos humanos tienen mayor amplitud....

En concordancia con este criterio, la Corte atribuye un alto valor probatorio a las declaraciones de los testigos antes mencionados, dentro del contexto y de las circunstancias de un caso de desaparición forzada, con todas las dificultades que de ésta se derivan, donde los medios de prueba son esencialmente testimonios indirectos y circunstanciales en razón a de la propia naturaleza de este delito. (Barbosa \& Bernal, 2015, p.311).

En la Sentencia del 29 de abril de 2004, que es el caso de la Masacre de Plan de Sánchez vs. Guatemala, la Corte a pesar del reconocimiento de la responsabilidad del Estado hace un 
recuento de los hechos relevantes para la sentencia, descubriendo el contexto y los toma como hechos probados.

La Corte, en esta sentencia, utiliza el contexto como un elemento probatorio y lo inserta en el acápite de hechos probados, para poder demostrar patrones sistemáticos de violaciones a los derechos humanos y al derecho internacional humanitario, a las cuales, les da diferentes calificaciones, tales como operaciones, prácticas y patrones.

Lo anterior, recordando que sus criterios de valoración de la prueba, son incompatibles con las reglas de derecho penal interno de cualquier país, ya que se fundamentó en la flexibilidad probatoria propia del derecho internacional de los derechos humanos.

Existe una gran diferencia en este sentido entre el Tribunal Europeo de Derechos Humanos y la Corte Interamericana de Derechos Humanos, ya que el Tribunal Europeo, busca evitar la calificación de los hechos como prácticas y modus operandi, mientras que la Corte sí utiliza dichas calificaciones, porque para ellos implica una agravación de la responsabilidad, y al mismo tiempo, una disminución de la carga probatoria por parte de las víctimas, de tal forma, que la posición flexible de la Corte Interamericana, no es generalizada a nivel internacional

La utilización del concepto de patrón, como reemplazo de los de práctica y de modus operandi, surge por medio de la Sentencia del caso Paniagua Morales y otros vs. Guatemala.

Para la Corte, en síntesis, el patrón es una sumatoria de prácticas que a su vez es la sumatoria de modus operandi, es decir, la sumatoria de conductas reiterativas que violan los derechos humanos y que hacen parte de un sistema. (Barbosa \& Bernal, 2015, p.312).

\subsubsection{El contexto para identificar crímenes de lesa humanidad}

La Corte Interamericana ha utilizado el análisis de los hechos como herramienta útil para determinar los elementos contextuales que forman parte de los crímenes de lesa humanidad, tales 
como la sistematicidad y la generalidad, para calificar graves violaciones de los derechos humanos.

Como ejemplo de lo anterior, tenemos la sentencia Almonacid Arellano vs. Chile del año 2008, en la cual, la Corte utilizó por primera vez el término contexto, con la finalidad de señalar que, "las circunstancias en que se produjo la muerte del señor Almonacid Arellano podrían constituir un crimen de lesa humanidad, conforme fuera definido para el año 1973". (Barbosa \& Bernal, 2015, p.312).

Para este caso, el término contexto era referido al análisis de la estructura criminal de la organización, y además tenía en cuenta toda una serie de elementos sociales, históricos y políticos de la época, con el fin de abarcar las relaciones que pudieran tener los diferentes homicidios entre sí, y determinar de ésta manera, la existencia de elementos contextuales propios de los crímenes de lesa humanidad.

Lo anterior significa, que dentro de un contexto de violaciones masivas y sistemáticas, podría determinarse una violación extrajudicial como crímenes de lesa humanidad, por lo tanto, la Corte tuvo que explicar el contexto de manera detallada, más allá de los hechos dentro del mismo caso.

A pesar de la gravedad de estos mismos hechos, la competencia material de la Corte Interamericana no le permite llegar a esta clase de clasificaciones, y la práctica jurídica de la Corte, sus reglas de procedimientos y prueba, y las presunciones en que se fundamenta, no son aptas para la determinación de responsabilidades penales, tal y como surge de la calificación del crimen internacional de lesa humanidad.

Dentro de esta misma sentencia, la Corte ha sido criticada, pues la calificación que se le da al crimen internacional por el Tribunal de Derechos Humanos, es un grave error que puede generar la tendencia a mezclar las prácticas jurídicas propias de los derechos humanos, con el objetivo de establecer imputaciones penales personales. 


\subsubsection{El análisis de contexto en la Corte Interamericana de Derechos Humanos, en casos contra el estado colombiano}

La primera sentencia en la cual, la Corte Interamericana hace uso del análisis de contexto para determinar la responsabilidad del Estado es en el caso de la Masacre de los 19 comerciantes, en la que se presenta como hechos probados el contexto del conflicto armado, y en especial, la creación de los grupos paramilitares en Colombia.

Este análisis de contexto, es utilizado por la Corte, en las sentencia de masacres ocurridas en manos de paramilitares en Colombia, para determinar la relación entre el Estado colombiano y los particulares que perpetraron dichos hechos, y establecer el grado de imputabilidad por el cual, el Estado está en la obligación de responder en cada uno de dichos casos (acción, omisión, tolerancia, aquiescencia, colaboración, etc...).

El estudio de la creación y del funcionamiento de los grupos de autodefensa, a nivel nacional y a nivel especifico, es realizado por la Corte, para estudiar los aspectos relevantes del hecho que se estudia, para determinar así la interacción de los grupos paramilitares con agentes del Estado.

Este análisis se presenta, en las masacres de Mapiripán, Pueblo Bello, Ituango, y La Rochela.

Dentro de la sentencia de la Masacre de los 19 comerciantes, la Corte hace el recuento histórico de la creación de los grupos paramilitares, su origen y la firma en que la normatividad nacional, al haber creado el marco para su origen, hace responsable al Estado.

La responsabilidad del Estado, es desarrollada en el contexto del caso colombiano, en la sentencia del caso de Pueblo Bello, en la cual, se determina lo siguiente:

La Corte observa que si bien la masacre de Pueblo Bello ocurrida en enero de 1990 fue organizada y perpetrada por miembros de grupos paramilitares, aquella no habría podido 
ejecutarse si hubiere existido protección efectiva de la población civil en una situación de riesgo razonablemente previsible por parte de miembros de las Fuerzas Armadas o de seguridad del Estado. Ciertamente no existen pruebas ante este Tribunal que demuestren que el estado dirigiera directamente la ejecución de la masacre o que existiese un nexo entre miembros del Ejército y los grupos paramilitares o una delegación de funciones públicas de aquél a éstos. No obstante, la responsabilidad por los actos de los miembros del grupo paramilitar en este caso en particular es atribuible al Estado en la medida en que éste no adoptó diligentemente las medidas necesarias para proteger a la población civil en función de las circunstancias descritas. Por las razones expuestas en los párrafos anteriores, la Corte concluye que el Estado no cumplió con su obligación de garantizar los derechos humanos consagrados en los artículos 4,5 y 7 de la Convención, por haber faltado a sus deberes de prevención y protección, en perjuicio de las personas desaparecidas y privadas de su vida en este caso. (Barbosa \& Bernal, 2015, p.314).

Lo que pretende la Corte, es vincular los hechos ocurridos, con la descripción de las obligaciones del Estado de respetar y garantizar los derechos humanos para establecer así, su responsabilidad internacional en los hechos ocurridos, ya que dentro de la misma sentencia se afirma que "es dentro del contexto descrito en que sucedieron los hechos del caso, que debe determinarse la observancia por parte del Estado de sus obligaciones convencionales de respeto y garantía de los derechos de las presuntas víctimas”. (Barbosa \& Bernal, 2015, p.308).

Para lograr lo anterior, lo que hace la Corte es desarrollar dentro de los hechos probados un contexto amplio sobre la creación de los grupos de las autodefensas y su transformación en grupos paramilitares, desde el ámbito normativo y fáctico, además, describe las características de la localidad de Pueblo Bello, para ubicar el momento de la masacre y las particularidades del lugar.

Destaca además, los hechos del ataque a la población y atribuye toda la responsabilidad al Estado de violar su obligación de prevenir, respetar y garantizar los derechos humanos de la población civil, ubicada dentro de la zona de conflicto. Para la Corte Interamericana, fue responsabilidad del Estado, al impulsar la creación de los paramilitares y la falta de control sobre 
ellos, la ausencia de la protección a la población dentro de la zona de conflicto y la falta de una correcta y efectiva investigación de éstos hechos, lo cual generó la violación de los derechos humanos.

La atribución de responsabilidad internacional, no se da por los hechos mismos de la masacre, sino por el contexto que permitió que estos mismos hechos se sucedieran, y dicha estrategia ha sido utilizada en diversos casos, pero en especial en el caso de la Masacre de Mapiripán, la Corte se enfrenta a un reconocimiento parcial de responsabilidad en el cual, existía controversia respecto a los hechos materia de análisis.

Por lo anterior, la Corte consideró que es "pertinente abrir un capítulo acerca de los hechos del presente caso, que abarque tanto los hechos reconocidos por el Estado al allanarse como los que resulten probados del conjunto de elementos que obran en el expediente". (Barbosa \& Bernal, 2015, p.316).

De la misma manera, la Corte determina que de conformidad con la naturaleza del caso, se debe hacer todo el análisis de responsabilidad y dictar una sentencia de fondo a pesar del allanamiento del Estado, en la cual, se establezca la verdad de los hechos y todos los elementos de fondo del asunto.

\subsubsection{La postura de la Fiscalía General de la Nación sobre el contexto, en la jurisprudencia interamericana de derechos humanos}

Durante el mes de mayo del año 2013, la Fiscalía General de la Nación en conjunto con la Cooperación Alemana y la Agencia de Cooperación Técnica, realizó el seminario internacional "Importancia de la Construcción de Contextos en las Investigaciones Judiciales". (Barbosa \& Bernal, 2015, p.316)

En el mencionado seminario, se construyó un concepto univoco de contexto, que ha manejado la Fiscalía y los jueces, y para el sector de la doctrina. 
Una de las conferencias mejor realizadas fue la del Doctor Juan Pablo Hinestrosa, quien realizó un análisis de la evolución de la jurisprudencia interamericana respecto de la construcción y la forma en la cual, debe ser analizado el tema del contexto y concluye de ésta forma, que el concepto de contexto, dentro de la jurisprudencia interamericana es el tercer escalón, después de las prácticas y de los patrones, el cual, es utilizado en el campo de la Justicia Transicional y cuyos componentes determinan los elementos propios de las estructuras criminales, así como el modus operandi, la practica o el patrón, y se analiza el contexto, como un medio de prueba para atribuir responsabilidad penal.

Para el Doctor Hinestrosa (2013), el concepto de contexto que es utilizado por la Corte Interamericana, se basa en las construcciones adelantadas por parte de órganos internos, tales como las comisiones de la verdad, que son consecuencia de la Justicia Transicional.

En relación con el proceso de Justicia y Paz, que se encuentra a cargo de la Fiscalía General de la Nación, y sus repercusiones dentro de la magistratura, fueron los pioneros en la utilización del contexto en Colombia, y la reforma al proceso implementada por medio de la Ley 1295 de 2012, implica una obligación específica para la Unidad, que es la de ir un escalón abajo en la escala de la construcción de la Corte interamericana, la cual, no se basa en construir contextos, sino en la construcción de patrones de macro criminalidad, en relación con los grupos armados al margen de la ley.

La construcción del contexto para Hinestrosa, no se encuentra en cabeza del órgano judicial, sino que siendo el contexto, construido por medio de órganos especializados tales como las Comisiones de la Verdad, le sirve a la Fiscalía para establecer las líneas lógicas de la investigación. El compromiso de Hinestrosa para la Unidad de Justicia y Paz, es el de construir patrones de macro criminalidad, compromiso que se enmarca en las funciones del ente investigador.

De conformidad con la posición del Doctor Hinestrosa, se comprende muy bien que aunque el contexto puede servir de prueba en los procesos de la Corte Interamericana, la Corte no los construye, solamente los obtiene de órganos especializados. La Fiscalía no puede tomar la 
construcción de contextos como prueba, ya que el desgaste es enorme e innecesario, pues la Fiscalía no es un órgano extrajudicial y además, porque lo que se logra establecer en un contexto, no sirve de prueba, dentro de un proceso penal, y para dar una respuesta en el Proceso de Justicia y Paz, la construcción de contextos, es pérdida de tiempo y de esfuerzos para esta entidad.

\subsubsection{Posturas frente al contexto en los organismos internacionales}

\subsubsection{Tribunal ad - hoc de Núremberg}

Dicho Tribunal, se ha encargado de determinar responsabilidad penal de dirigentes, funcionarios y colaboradores del régimen nazi en relación de los crímenes y abusos en contra de la humanidad, cometidos en nombre del tercer reich alemán.

En general se trataba de procesos, en los cuales, se terminó imponiendo la voluntad de los vencedores sobre los vencidos, (i) en el desarrollo de los juicios de Núremberg, (ii) en la Carta de Londres que le sirve de marco de referencia o (iii) en las diversas sentencias dictadas dentro de ese mismo escenario, pero "no se hace alusión expresa al concepto de "contexto"; mucho menos aún se insinúa la posibilidad de que el mismo pudiese ser un elemento probatorio o un criterio de imputación”. (Barbosa \& Bernal, 2015, p.353).

Pero lo que sí se presenta, es la tendencia a no apreciar los hechos de manera aislada, sino de encuadrarlos en el suceso general, lo cual, fundamenta la competencia de este Tribunal.

Por otra parte, se debe tener en cuenta, que más allá de la significación individual de cada suceso, es el contexto de la guerra propiciada, por parte del régimen nazi, comprensivo de las características, finalidades y consecuencias de su ejecución, lo que llevó a la creación de éste novedoso instrumento de justicia internacional.

En este Tribunal, pese a las limitaciones a ciertas garantías, "la responsabilidad de los procesados se determinó con riguroso fundamento en pruebas que permitieran aseverar o 
desvirtuar la participación en el hecho criminal, conforme a los criterios de imputación desarrollados hasta entonces por la dogmática penal”. (Barbosa \& Bernal, 2015, p.353).

\subsubsection{Tribunales ad - hoc para la Antigua Yugoslavia y Ruanda}

Dentro de la jurisprudencia de dicho Tribunal se acogió la tesis de la llamada empresa criminal conjunta, en tres categorías que son las siguientes: (i) la básica, que refiere caso en que todos los co - perpetradores (coautores), actúan persiguiendo el propósito común, y poseen la misma intención criminal, para cometer el crimen que se ha imputado, (ii) la sistémica, que se refiere a actos cometidos por el individuo como parte de la implementación de un sistema represivo, como por ejemplo los campos de concentración, y (iii) la amplia, que se refiere a casos, en los que el crimen imputado, aunque fuera del propósito (designio) común, es una consecuencia natural y previsible de ejecutar ese propósito o designio común.

En la sentencia Brdanin vs. The Prosecutor, se insiste en que bajo cualquiera de estas tres categorías, se logre una condena, ha de exigirse a la autoridad requirente la demostración de que el acusado participó de la empresa criminal conjunta, teniendo que probarse tres elementos en ese mismo aspecto, los cuales son: (i) la pluralidad de personas involucradas, (ii) la existencia del designio o plan común y (iii) la participación del acusado en ese designio común, con la demostración de su participación y responsabilidad.

Es decir, que quien requiere al individuo ha de hacer un análisis exhaustivo de sus actos y de su conducta, recogiendo toda la prueba que asegure poder desvirtuar su inocencia y logre demostrar su participación, bajo una de las categorías anteriormente enunciadas.

En las jurisprudencias de los Tribunales Ad - Hoc para la Antigua Yugoslavia y Ruanda, la construcción de contextos es un instrumento útil para comprender todo lo ocurrido y para formular una teoría sobre el modus operandi, que caracterizó a ciertas situaciones; es decir, que el contexto es una herramienta útil y necesaria dentro de la investigación de acontecimientos complejos; no existe referencia alguna a que el análisis de contexto puede ser utilizado como elemento probatorio a fin de demostrar responsabilidades individuales, pues más allá de la 
existencia de la empresa criminal conjunta, se exige demostrarle al Tribunal de las responsabilidades individuales en contra del enjuiciado, las cuales, difieren de las estatales.

\subsubsection{Tribunal Europeo de Derechos Humanos}

Este Tribunal utiliza el contexto como parte de la responsabilidad por acciones o por omisiones del Estado, pero deja claro, que esta y otras nociones semejantes, no son viables a la hora de establecer responsabilidad individual.

Para este mismo Tribunal, la responsabilidad se limita solo a la declaración de responsabilidad estatal, en tanto permanece la obligación de recoger la prueba o al menos indicios probatorios racionales suficientes que atribuyan el hecho particular, no solamente al Estado, sino también a sus agentes, que al estar plenamente identificados, deben responder directamente por sus conductas.

\subsubsection{Corte Interamericana de Derechos Humanos}

La Convención Americana sobre Derechos Humanos, creó dos órganos competentes para conocer de las violaciones a los derechos humanos como son, la Comisión Interamericana de Derechos Humanos y la Corte Interamericana de Derechos Humanos, como institución judicial autónoma, la cual tiene como objetivo la interpretación y aplicación de la Convención y cuya jurisprudencia es vinculante para el Estado Colombiano.

Esta última, dentro de los desarrollos del derecho a la verdad, ha realizado referencias al concepto del contexto, por lo tanto, es de vital importancia dentro del presente trabajo, hacer referencia a algunos de sus pronunciamientos sobre el tema, para posteriormente, determinar los alcances en la aplicación de tal instituto dentro del derecho interno colombiano.

Dentro del libro "Los estándares de la Corte Interamericana y la Ley de Justicia y Paz" (2009), Manuel Quinche, explica que en alguna decisiones de la Corte las primeras aproximaciones a la elaboración de los estándares de verdad, la justicia y reparación, se 
efectuaron a partir de pronunciamientos de hechos a finales de la década de los años ochenta y en 1998, con el fallo del caso Velásquez vs. Honduras, y con el caso de Myrna Mack vs. Guatemala de 2003.

La Corte, ha reiterado que toda persona, incluyendo familiares de víctimas de graves violaciones de derechos humanos, tiene el derecho a la verdad. En consecuencia, los familiares de las víctimas y la sociedad como un todo deben ser informados de todo lo sucedido en relación a dichas violaciones. Este derecho a la verdad, ha venido siendo desarrollado por el Derecho Internacional de los Derechos Humanos, al ser reconocido y ejercido en una situación concreta, ello constituye un medio importante de reparación. Por lo tanto, en este caso da lugar a una expectativa que el Estado, debe satisfacer a los familiares de la víctima y a la sociedad.

La Corte en los términos anteriores, determina como obligación de los Estados, la de investigar y sancionar a las autoridades de los hechos, y además, a quienes no cumplen con la obligación de esclarecer la verdad, y dentro del escenario de la verdad, hace referencia a los conceptos de contexto, patrones y modus operandi, así como al valor probatorio de las comisiones de la verdad, en el caso Osorio Rivera y familiares vs. Perú (2013).

La misma Corte a efectos de difundir la responsabilidad del Estado, reconoce la importancia de llevar a cabo investigaciones que incluyan la valoración del contexto en el cual se desarrollan los hechos, a tal punto de que da un valor probatorio especial a algunos informes de las comisiones de la verdad, los cuales utiliza para la construcción de los contextos.

El procedimiento de investigación, supone la habilitación de una serie de instrumentos no habituales de investigación judicial ordinaria, como medios de prueba dentro del contexto internacional; sin embargo, un análisis detenido de toda la argumentación evidencia, que lo que se plantea es que dentro de la determinación de la responsabilidad de los Estados, la Corte no considera pertinente trasladar los criterios de los procedimientos judiciales internos, los cuales, buscan determinar responsabilidades penales individuales. 
Si un Estado asume con seriedad el cumplimiento de sus deberes, lo debe demostrar adecuadamente; de esta manera, más que estructurar una metodología confiable para la reconstrucción histórica de un suceso, la Corte habilita normativamente fórmulas que permitan acoger una hipótesis, que los Estados en cuestión podrían desvirtuar, a través de pruebas.

No se trata en realidad, de atribuir responsabilidad penal a personas naturales, sino de exigirle a los Estados el cumplimiento de sus deberes, y por tal razón, la Corte determina que es legítimo acudir a mecanismos alternativos para poder reconstruir la verdad, así como a la implementación de unos estándares de prueba diversos a los que operan en la administración de justicia penal interna de cada Estado.

La Corte reconoce la construcción del contexto, como una herramienta eventualmente útil para evitar y aminorar los índices de impunidad, pero el mismo contexto, no puede utilizarse para reemplazar los elementos probatorios que permitan establecer responsabilidades penales individuales.

Dentro del Sistema Interamericano de Derechos Humanos, se determina que una cosa es la opción (muchas veces aconsejable) de construcción de contextos para diversos propósitos y otra, es que con esos contextos, más allá de la declaración de responsabilidad objetiva estatal, incluyan el análisis de contexto, en el Derecho Internacional.

En el marco de los delitos que forman parte del derecho internacional, se asimilan de igual manera, las características de la macrocriminalidad.

Esta configuración precisa, además del hecho individual ("acto"; "cualquiera de los actos siguientes"), el contexto de la violencia organizada ("contexto" o "circunstancias de contexto"), que siendo elemento internacional, convierte el hecho en crimen de derecho internacional.

El elemento contextual está contenido en cada delito, bien como elemento objetivo del mismo o como parte integrante del aspecto interno del hecho. En el genocidio, el contexto se configura como un elemento subjetivo del delito de manera que el autor debe perseguir la 
destrucción de un grupo protegido. (Werle, G., Burchards, W., Jessberger, F., Luders, B., y otros. 2005, p.179).

Pero en lo que respecta a los crímenes de lesa humanidad, los crímenes de guerra y el crimen de agresión, el elemento contextual se integra en los elementos objetivos del crimen.

El ataque generalizado o sistemático en contra de la población civil (hecho global) dentro de los crímenes de lesa humanidad, constituye un elemento del aspecto externo del tipo del crimen, al igual que el conflicto armado en los crímenes de guerra. También en el crimen de agresión, la utilización de violencia organizada pertenece al aspecto externo del hecho”. (Werle, G., Burchards, W., Jessberger, F., Luders, B., y otros. 2005, p.180).

\subsection{El delito de desplazamiento forzado, en la jurisprudencia del Tribunal Penal Internacional para la antigua Yugoslavia}

Desde la Jurisprudencia del Tribunal Penal Internacional para la Antigua Yugoslavia, el delito de desplazamiento forzado por la violencia, es considerado un crimen de igual gravedad que los demás enunciados en el artículo $5^{\circ}$., del Estatuto de Roma, y al respecto la Sala de Apelaciones en el caso Krnojelac dispone lo siguiente:

Los desplazamientos forzosos, tomados por separado o acumuladamente, pueden constituir un crimen de persecución de igual gravedad que otros crímenes enumerados en el artículo 5 del Estatuto [...].

La Sala de Apelaciones concluye que los desplazamientos dentro de un Estado o a través de la frontera nacional, por razones no permitidas por el derecho internacional, son crímenes punibles conforme al derecho internacional consuetudinario, y estos actos, si son cometidos con la intención discriminatoria requerida, configuran el crimen de persecución conforme al artículo 5(h) del Estatuto. (Del Campo Steta, 2006, p.267).

En el caso enunciado anteriormente, el Acta de Acusación determinó, que tanto la deportación, el traslado forzoso y el desplazamiento forzado, constituyeron delitos de igual 
gravedad que los demás delitos enunciados en el artículo $5^{\circ}$., del Estatuto de Roma, y que por lo tanto, también de igual manera se podrían equiparar a persecución como un crimen de lesa humanidad.

Al respecto, en el caso Blagojevic y Jokic, en Sala de Primera Instancia, el día 17 de Enero de 2005, en el párrafo 602, se determina lo siguiente, referente al delito de desplazamiento forzado:

La Sala de Primera Instancia encuentra que el traslado forzoso, tomado por separado o acumuladamente, y cuando es cometido sobre bases discriminatorias es de igual gravedad que otros crímenes enumerados en el artículo 5 del Estatuto y por lo tanto puede constituir persecución. (Del Campo Steta, 2006, p.267).

Por su parte, en el caso Brdjanian, en Sala de Primera Instancia, del $1^{\circ}$., de Septiembre de 2004, en su párrafo 1.025, determinó lo siguiente:

La Fiscalía formula cargos de deportación o traslado de bosnio-musulmanes y bosniocroatas [...] de áreas dentro de los Municipios de la [Región Autónoma de Krajina] [...] a áreas bajo el control del gobierno legítimo de Bosnia y Herzegovina (Travnik) y Croacia (Karlovac)' como persecuciones. Estos actos se imputan por separado como deportación (un crimen de lesa humanidad según el artículo 5(d) del Estatuto) y como actos inhumanos (traslado forzoso) (un crimen de lesa humanidad según el artículo 5(i) del Estatuto) y como tales son por definición de gravedad suficiente para constituir persecución. (Del Campo Steta, 2006, p.267).

Finalmente, en los casos Simic, Tadic y Zaric, en Sala de Primera Instancia, del día 17 de octubre de 2003, en su párrafo 121, se especifica:

Mientras que el artículo 5(d) del Estatuto prohíbe la 'deportación', el traslado forzoso no está explícitamente mencionado en el artículo 5(d) y (h) del Estatuto. De allí, que el traslado forzoso sólo pueda constituir un acto persecutorio si se equipara a una negación 
'lisa y llana con motivos discriminatorios, de un derecho fundamental, establecido por el derecho internacional consuetudinario o derecho de los tratados, alcanzando el mismo nivel de gravedad que los demás actos prohibidos en el artículo 5' del Estatuto. (Del Campo Steta, 2006, p.267).

\subsubsection{Los desplazamientos son punibles conforme al derecho internacional consuetudinario}

En el caso Krnojelac, la Sala de Apelaciones, el día 17 de Septiembre de 2003, en el párrafo 223 determinó lo siguiente:

La Sala de Apelaciones sostiene en que en el momento en que tuvo lugar el conflicto en la antigua Yugoslavia, los desplazamientos tanto dentro del Estado como a través de la frontera nacional constituyeron crímenes conforme al derecho internacional consuetudinario. (Del Campo Steta, 2006, p.268).

Posteriormente, en los casos Blagojevic y Jokic, en Sala de Primera Instancia del día 17 de Enero de 2005, en el párrafo 595, se determinó lo siguiente:

Está bien establecido que los desplazamientos dentro de un Estado o a través de las fronteras nacionales, por causas no permitidas por el derecho internacional, son crímenes punibles conforme al derecho internacional consuetudinario. (Del Campo Steta, 2006, p.268).

\subsubsection{Definición de deportación, traslado forzoso y desplazamiento forzado.}

En el caso Blagojevic y Jokic, de la Sala de Primera Instancia el día 17 de Enero de 2005, en el párrafo 595, se determina lo siguiente:

El crimen de traslado forzoso ha sido definido en la jurisprudencia de este Tribunal como el desplazamiento forzoso de personas sin fundamento permitido por el derecho 
internacional de áreas en donde están lícitamente presentes. Tradicionalmente, la distinción entre el traslado forzoso y la deportación es que el primero consiste en desplazamientos forzosos de personas dentro de fronteras estatales, mientras que el segundo consiste en el desplazamiento forzoso más allá de las fronteras internacionalmente reconocidas del Estado. (Del Campo Steta, 2006, p.268).

En el caso Brdjanin, de la Sala de Primera Instancia del día $1^{\circ}$ de septiembre de 2004, en el párrafo 540, se define lo siguiente:

Tradicionalmente, la distinción entre el actus reus de 'deportación' y 'traslado forzoso' se identifica con el destino al que las personas son desplazados. La Sala de Primera Instancia hace notar que la mayoría de las sentencias de los juicios de este Tribunal que se han referido a esta cuestión, han sostenido que bajo el derecho internacional consuetudinario, la ‘deportación' consiste en el desplazamiento forzoso de personas más allá de las fronteras internacionalmente reconocidas del Estado. En contraste, el 'traslado forzoso' puede consistir en el desplazamiento forzoso dentro de fronteras estatales. (Del Campo Steta, 2006, p.268).

Finalmente, en el caso Blaskic, de la Sala de Primera Instancia del día 3 de marzo de 2000, en el párrafo 234, se presenta la siguiente definición:

La deportación o traslado forzoso de civiles [como una forma del crimen de persecución] significa el desplazamiento forzoso de las personas a las que concierne mediante deportación u otros actos coercitivos, del área en la que se encuentran lícitamente presentes, sin fundamentos permitidos por el derecho internacional. (Del Campo Steta, 2006, p.268). 


\subsubsection{El delito de desplazamiento forzado, no se limita a través de una frontera nacional}

En el caso Krnojelac, en Sala de Apelaciones, de fecha 17 de septiembre de 2003, en el párrafo 2918, se establece lo siguiente:

La sala de Apelaciones sostiene que los actos de desplazamiento forzoso relacionados con el crimen de persecución, punible conforme al artículo 5(h) del Estatuto, no se limitan a desplazamientos a través de una frontera nacional. La prohibición contra los desplazamientos forzosos tiene como finalidad la salvaguarda del derecho y aspiración de las personas a vivir en sus comunidades y hogares sin interferencia externa. El carácter forzoso del desplazamiento y el arrancar de sus raíces y por la fuerza a los habitantes de un territorio, acarrea la posibilidad penal del perpetrador, no así el destino al que son enviados esos habitantes. (Del Campo Steta, 2006, p.268 - 269).

En la misma Sentencia, del caso Krnojelac, en Sala de Apelaciones, de fecha 17 de septiembre de 2003, en sus párrafos 221 - 222, se determina que "En diversas ocasiones las Salas de Primera Instancia del Tribunal han encontrado que el desplazamiento forzoso de la población dentro de un Estado o a través de su fronteras constituyó persecución”. (Del Campo Steta, 2006, p.269).

Finalmente, la Sala de Apelaciones del Tribunal Penal Internacional para la Antigua Yugoslavia, finaliza con el siguiente análisis:

La Sala de Apelaciones concluye que los desplazamientos dentro de un Estado o a través de una frontera nacional, por razones no permitidas conforme al derecho internacional, son crímenes punibles conforme al derecho penal internacional consuetudinario, y estos actos, si son cometidos con la intención discriminatoria requerida, constituyen el crimen de persecución definido en el artículo 5(h) del Estatuto. (Del Campo Steta, 2006, p.269). 


\subsection{Consideraciones generales sobre los crímenes de lesa humanidad}

En el caso de que las acciones individuales sean realizadas "como parte de un ataque generalizado o sistemático contra la población civil”, estamos frente a crímenes de lesa humanidad y desde el punto de vista subjetivo, se exige que el autor tenga conocimiento de dicho ataque.

Es importante destacar, que con las exigencias del actuar del autor, dentro de esta clase de crímenes, se hace referencia a las circunstancias de su actuar, es decir, que su acción es puesta en un determinado contexto de comisión, que la convierte en un crimen en contra de la humanidad.

De acuerdo a lo anterior, el autor debe conocer este contexto de comisión, y de este modo también el ataque.

Es importante destacar, que en contra del carácter declarativo del elemento del conocimiento del ataque, este no tiene nada que ver con las verdaderas acciones individuales, como son el homicidio, la tortura, la violación, etc..., ya que se encuentra fuera de tales acciones, establecido una referencia subjetiva del marco de referencia característico del crimen contra la humanidad. Lo anterior significa, que el conocimiento del ataque no representa un elemento subjetivo del tipo, sino que integra el dolo.

Si se exige un conocimiento preciso por parte del autor de la política o plan sobre el que se basan los crímenes contra la humanidad, entonces difícilmente se podrá demostrar el conocimiento de alguno de los intervinientes en tales crímenes.

El anterior argumento, corresponde a lo siguiente:

La planificación de una política criminal está reservada típicamente al pequeño grupo de conducción, el cual cuidará de que los ejecutores exteriores de esa política conozcan sólo lo estrictamente necesario para su misión. Pero, por otra parte, el contentarse con el mero conocimiento del ataque en cuento tal es pasible de la objeción de que un requerimiento de 
dolo tan escaso no satisface la importancia del "policy element" como caracterizados de la naturaleza delictiva del crimen contra la humanidad. (Ambos, 2005, p. 403).

Lo anterior significa, que el autor deberá promover el ataque, pudiendo inferirse su voluntad de promoción, al igual que el conocimiento de los hechos y circunstancias relevantes, es decir, que es suficiente que el autor haya actuado a sabiendas o voluntariamente en relación con el ataque generalizado o sistemático, y esto significa, que el autor debe saber que no ha actuado aisladamente, sino en el marco de un ataque generalizado o sistemático, sin que deba tener un conocimiento detallado de ese ataque.

Esto significa, que el acusado debe saber y conocer que su conducta, se encuentra dentro de un ataque sistemático y generalizado y que va en contra de la población civil, y que este mismo conocimiento debe incluir la asunción de un riesgo deliberado con la esperanza de que no cause perjuicios.

Lo anterior, permite concluir lo siguiente:

El autor debe tener un conocimiento general de que los hechos han formado parte de un ataque sistemático y basado en una política en sentido amplio contra una población civil. (Del Campo Steta, 2006, p.406).

\subsubsection{Características de los crímenes de lesa humanidad}

\subsubsection{El Ataque}

El elemento ataque, describe una línea de conducta, dentro de la cual, deben ser integrados los hechos individuales, es decir, que dicha línea de conducta implica la "comisión múltiple" de los actos mencionados dentro del Artículo 7.1. del Estatuto de Roma de la Corte Penal Internacional ("línea de conducta que implique la comisión múltiple de actos"). 
La comisión múltiple conlleva dentro de sí, menos exigencias que el ataque "generalizado", debido a que una comisión múltiple existe cuando se comete en varias ocasiones una misma acción típica, es decir, cuando se comenten distintas alternativas típicas, y para lograr lo anterior, no se requiere que el mismo autor actúe en todos los casos.

Esto se explica, cuando un único asesinato puede constituirse en un crimen contra la humanidad, cuando este hecho individual forme parte de la relación funcional del conjunto.

Al respecto Werle, G., Burchards, W., Jessberger, F., Luders, B., y otros, (2005) determinan lo siguiente:

no se requiere de un ataque militar para que exista un hecho global, como lo señalan los Elementos de los Crímenes, debido a que "no es necesario que los actos constituyan un ataque militar", y tampoco es necesario el ejercicio de la violencia en contra de la población civil”. (p. 361).

\subsubsection{El carácter generalizado o sistemático}

96. (...) [L]a Corte reconoce que los crímenes contra la humanidad incluyen la comisión de actos inhumanos, como el asesinato, cometidos en un contexto de ataque generalizado o sistemático contra una población civil. Basta que un solo acto ilícito como los antes mencionados sea cometido dentro del contexto descrito, para que se produzca un crimen de lesa humanidad (...). Todos estos elementos ya estaban definidos jurídicamente cuando el señor Almonacid Arellano fue ejecutado.

99. (...) [L]a Corte encuentra que hay amplia evidencia para concluir que en 1973, año de la muerte del señor Almonacid Arellano, la comisión de crímenes de lesa humanidad, incluido el asesinato ejecutado en un contexto de ataque generalizado o sistemático contra sectores de la población civil, era violatoria de una norma imperativa del derecho internacional. Dicha prohibición de cometer crímenes de lesa humanidad es una norma de 
ius cogens, y la penalización de estos crímenes es obligatoria conforme al derecho internacional general.

110. La obligación conforme al derecho internacional de enjuiciar y, si se les declara culpables, castigar a los perpetradores de determinados crímenes internacionales, entre los que se cuentan los crímenes de lesa humanidad, se desprende de la obligación de garantía consagrada en el artículo 1.1 de la Convención Americana. Esta obligación implica el deber de los Estados Partes de organizar todo el aparato gubernamental y, en general, todas las estructuras a través de las cuales se manifiesta el ejercicio del poder público, de manera tal que sean capaces de asegurar jurídicamente el libre y pleno ejercicio de los derechos humanos. (...)

111. Los crímenes de lesa humanidad producen la violación de una serie de derechos inderogables reconocidos en la Convención Americana, que no pueden quedar impunes. (...)

Asimismo, la Corte ha determinado que la investigación debe ser realizada por todos los medios legales disponibles y orientada a la determinación de la verdad y la investigación, persecución, captura, enjuiciamiento y castigo de todos los responsables intelectuales y materiales de los hechos, especialmente cuando están o puedan estar involucrados agentes estatales. (...) (San José de Costa Rica, Corte Interamericana de Derechos Humanos, 2006, Caso Almonacid Arellano y otros vs. Chile, p.4 -5).

Dentro del Estatuto de Roma se acordó que los requisitos de los Crímenes de Lesa Humanidad, como son "generalizado" y "sistemático", debían tener cabida dentro del tipo penal. Dichos requisitos deben tener una relación alternativa, con la medida adicional de definir legalmente el "ataque contra la población civil", con el elemento político que tiene contenido dentro del Artículo 7.2., del Estatuto de la Corte Penal Internacional.

El carácter generalizado, es un elemento cuantitativo del hecho global, debido a que la generalidad del ataque se determinará a partir de la cantidad de víctimas, y la misma se puede derivar, de su extensión sobre un determinado ámbito geográfico amplio, aunque dicha 
característica no es imprescindible, para que se dé dicho requisito. Lo anterior, porque el ataque generalizado puede consistir en una sola acción cuando ésta tiene como víctimas a una gran número de personas civiles.

Al respecto, Werle, G., Burchards, W., Jessberger, F., Luders, B., y otros, (2005), determinan lo siguiente:

La calificación del ataque como "sistemático" es de naturaleza cualitativa. Se refiere a la naturaleza organizada de los actos de violencia y a la improbabilidad de su ocurrencia por mera coincidencia. Exige que las acciones individuales deriven de un plan previo o de una política. (p.363).

De conformidad con lo anterior, la Jurisprudencia de los Tribunales ad hoc ha seguido dicha interpretación y determina la necesidad del mencionado plan o política. Además, y de conformidad con el Artículo 7.1., del Estatuto de Roma de la Corte Penal Internacional, se determina que los requisitos como son "generalizado" y "sistemático" solo pueden concurrir de manera alternativa, aunque en la práctica generalmente se cumplirán ambas características.

\subsubsection{En contra de la población civil}

El artículo $7^{\circ}$. numeral $3^{\circ}$., del Estatuto de Roma, explica a fondo esta característica, de la siguiente manera:

(...) se entenderá una línea de conducta que implique la comisión múltiple de los actos indicados en el párrafo 1 del artículo 7 del Estatuto contra una población civil a fin de cumplir o promover la política de un Estado o de una organización de cometer esos actos. No es necesario que los actos constituyan un ataque militar. Se entiende que la <política....de cometer dichos actos> requiere que el Estado o la organización promueva o aliente activamente un ataque de esa índole contra una población civil. (González, González, 1998, 162 - 163). 
No se trata de cualquier acto, sino de aquellos que se realicen o cometan de manera plural, y que dichos ataques formen parte de una política de Estado o de una organización en particular; esto significa de conformidad con lo regulado en el Estatuto de Roma, que los delitos de lesa humanidad, no son competencia exclusiva de los funcionarios o de las autoridades del Estado, sino que abarcan además, a agentes no estatales, en el caso de que lleguen a formar parte de una organización, de esta forma se amplía la responsabilidad de los autores de estos crímenes.

Es importante definir qué se entiende por población civil, como aquella población que "no toma parte en las hostilidades en un conflicto armado, ni nacional ni internacional". (González, González, 1998, 162).

El Protocolo Adicional I de los Convenios de Ginebra de 1949, precisa su significado, al determinar que "Es persona civil cualquiera que no pertenezca a una de las categorías de personas a que se refieren el artículo 4, A.1), 2). 3) y 6) del III Convención, y el artículo 43 del presente Protocolo (...)"(González, González, 1998, 163).

Finalmente, es importante precisar, que la doctrina mayoritaria ha establecido la interpretación de que no es necesario que los ataques estén dirigidos contra toda una población civil, pues es suficiente que estén dirigidos a una parte de ella. 


\section{Capítulo 3}

\section{Metodologías de investigación penal, con base en criterios de priorización, para crímenes de lesa humanidad perpetrados en Colombia}

\subsection{La investigación penal de análisis de contexto en el derecho penal colombiano}

\subsubsection{La construcción del contexto en el derecho penal y procesal penal colombiano}

Analizando los referentes internacionales del Derecho Penal, es decir, las decisiones de los Tribunales ad - hoc de Núremberg, de los Tribunales para la Antigua Yugoslavia y Ruanda, en las Cortes Europea e Interamericana de Derechos Humanos y en las fuentes nacionales, es decir, los Códigos Pernales de 1936, 1980 y 2000, vinculan la expresión contexto, con las circunstancias de tiempo, modo y lugar, en las cuales, tiene ocurrencia un hecho concreto con relevancia dentro del Derecho Penal.

En primer lugar, es conveniente entrar a analizar la dimensión y la naturaleza de los delitos perpetrados, en particular los que suponen colaboración de varios agentes y de los cuales, se constituyen graves violaciones a los derechos humanos o al derecho internacional humanitario, debido a que a la gran importancia y trascendencia de los mismos, se requiere de una metodología de investigación, basada en la construcción de contextos, la cual, se opone a la investigación del delito de forma aislada, esto es, como la acción perpetrada por un agente único el cual se considera con independencia de su entorno.

La utilización de la metodología de investigación en contexto, en el ámbito del Sistema Interamericano de Derechos Humanos es muy laxo a nivel probatorio, y dentro del marco de las investigaciones sobre la responsabilidad internacional del estado por las violaciones cometidas contra los Derechos Humanos; la Corte Interamericana de Derechos Humanos, utiliza la investigación en contexto, con el objetivo de plantearse una hipótesis razonable acerca de la forma en la cual, fueron acaecidos los hechos de tales violaciones, la cual, busca invertir la carga de la prueba. 
Por lo tanto al Estado, que es el investigado, es al ente a quien después de la construcción de un contexto, le corresponde desvirtuar su responsabilidad internacional por el incumplimiento de los deberes y obligaciones que derivan de la Convención Americana sobre Derechos Humanos, y de las demás normas convencionales de dicho sistema regional, y si el Estado no logra desvirtuar dicha responsabilidad, la misma le será atribuida.

Sobre el particular, Barbosa (2015) determina lo siguiente:

En lugar de intentar reconstruir un hecho a través del método probatorio tradicional del Justicia Penal Ordinaria, la Corte opta por construir contextos que le permiten, con mayor flexibilidad y sin el rigor de los estándares probatorios, aproximarse a la verdad y derivar de ellos las consecuencias jurídicas que correspondan. (Barbosa Castillo y Bernal Pulido, p. 34)

Otra conexión entre el derecho interamericano de los derechos humanos y el derecho penal interno en relación con el análisis de contexto, se presenta por medio del respaldo que la Corte Interamericana le ha dado a dicha metodología de investigación, para que la misma sea utilizada de manera heurística dentro de la investigación penal, por parte de las autoridades que desarrollan esta labor al interior de los Estados, y sobre todo, dentro de las investigaciones penales sobre graves violaciones a los derechos humanos o a las normas del derecho internacional humanitario.

Por otra parte, la Corte Interamericana determina, que por medio de la metodología de análisis de contexto, se facilita a los investigadores de crímenes atroces trazarse líneas de investigación razonables, y dirigir la recolección de las pruebas pertinentes para demostrar la realización de los hechos punibles y lograr de esta forma determinar la responsabilidad de las personas que actuaron como autores o partícipes dentro de los mimos hechos.

Por su parte, el tratadista Gerardo Barbosa Catillo ha llegado a la conclusión de que la metodología de análisis de contexto, no se ha regulado como una categoría independiente, la cual, difiere de la conclusión a la que el mismo tratadista ha llegado, después de analizar las 
normas que fundan el sistema procesal penal colombiano y las normas que rigen el sistema de Justicia Transicional, ya que en dichas normas, el legislador determina la necesidad de investigar todo el delito en su contexto y no de manera aislada.

Por otra parte, se ha dado gran respaldo por parte de la Corte Constitucional a la utilización de la metodología de análisis de contexto, en la Sentencia C - 579 de 2013, pero dicho análisis se basa en la jurisprudencia que forma parte de la Justicia Penal Ordinaria y estudia dicha figura en Sentencias de la Sala Penal de la Corte Suprema de Justicia.

Al utilizar la metodología de análisis de contexto, se logran clamar las tensiones que crea la contraposición entre las exigencias del debido proceso de los investigados y los derechos a la verdad, a la justicia y a la reparación integral de las víctimas, al investigar delitos que atenten contra los derechos humanos que han sido ejecutados por empresas criminales conjuntas y/o aparatos organizados de poder.

Por medio de la Directiva 01 de 2012 y de la Resolución 1810 de 2012, así como de otras fuentes de carácter interno de la Fiscalía General de la Nación, se hace necesario implementar el modelo del análisis de contexto, dentro del sistemas de la justicia penal ordinaria colombiana, para investigar crímenes de alto impacto, pues éste modelo de investigación criminal acoge criterios de organismos internacionales y líneas jurisprudenciales de la Corte Suprema de Justicia y de la Corte Constitucional en su conjunto.

De conformidad con lo anterior, es conveniente destacar que no es pertinente trasplantar sin ajuste de ninguna clase, a la Justicia Penal Ordinaria, criterios elaborados en el Derecho Penal Internacional de los Derechos Humanos y del Derecho Internacional Humanitario, debido a que en algunos casos, debe existir afinidad entre el contexto internacional y el doméstico, además, la diferencia en lo que concierne a los marcos teóricos y normativos de cada sistema exige, que la metodología de análisis de contexto sea utilizada dentro de cada uno de ellos con sus particularidades y características propias. 
Se debe diferenciar el uso del análisis de contexto dentro del marco de la Justicia Transicional respecto de la que se puede tener dentro del marco de la Justicia Penal Ordinaria, y dicha diferenciación, debe dar lugar a expedir una regulación específica para cada uno de dichos entornos.

Además, el termino contexto se debe precisar muy bien, es decir, en la forma apropiada de construirlo desde un punto de vista técnico y disciplinario y no ser empleado como un medio de prueba, y sus conclusiones tampoco pueden emplearse, como criterio de imputación en el ámbito del derecho penal interno, simplemente es una heurística de investigación.

\subsubsection{Problemas teóricos de la investigación de análisis de contexto en el Derecho Penal Colombiano}

\subsubsection{El problema conceptual}

El problema funcional del análisis de contexto deriva de dos factores principales, el primero de ellos consiste en que la Fiscalía General de la Nación, utiliza el concepto de análisis de contexto desde varias conceptuaciones, en segundo lugar, se busca establecer las pertinencias de establecer las relaciones que existen entre el análisis de contexto y los conceptos de designio común, empresa criminal conjunta, modus operandi, practica y patrón.

\subsection{La diferencia entre el concepto y la concepción en filosofía y en la teoría del derecho}

El uso en el derecho de conceptos que dan lugar a desacuerdos profundos ha suscitado en la filosofía general y en la teoría del derecho, la distinción entre concepto y concepción, debido a que los conceptos se refieren a ideas generales, por ejemplo la idea de justicia, mientras que las concepciones, hacen referencia a los variados entendimientos que los teóricos pueden tener de cada uno de dichos conceptos, por ejemplo, las teorías utilitarista y deontológicas, expresan diferentes concepciones de la justicia. 
La diferencia ente el concepto y la concepción se debe al filósofo William Gallie, quien en 1956 escribió el artículo "Conceptos esencialmente controvertidos", dentro del cual, la, idea fundamental para este filósofo es la siguiente:

... ciertos conceptos teóricos que se aplican en la moral y en el derecho, tales como los que aluden a lo "justo", lo "correcto" y lo "bueno", son esencialmente controvertidos. Estos conceptos parecen tener un significado que en parte es compartido por quienes los usan, como por ejemplo, que es bueno evitar sufrimientos innecesarios. Sin embargo, más allá de esa zona de acuerdo, estos conceptos dan lugar a disputas y a que sean usados por los teóricos de formas diversas y a veces inconsistentes entre sí. (Barbosa Castillo y Bernal Pulido, p.34).

Posteriormente John Rawls, aludió a la distinción entre el concepto de justicia y la existencia de diversas concepciones a nivel particular acerca de la justicia, y dentro de ése mismo orden de ideas, Rawls defendió su idea de justicia como equidad, que para él sería la mejor concepción de justicia.

Ronald Dworkin en 1988, se valió de la diferencia entre concepto y concepción en el libro "El imperio de la justicia", la idea de Dworkin era que cuando interpretan los conceptos constitucionales de igualdad, los jueces deben determinar cuál es la concepción que se tiene de dichos conceptos, es decir, la concepción de igualdad que mejor se ajuste a la práctica del derecho, de ésta forma, se logra analizar, que la diferencia entre concepto y concepción lleva a los juristas a escudriñar cuál de las diferentes concepciones sobre un determinado concepto es la más apropiada.

La existencia de varias concepciones acerca de los conceptos también se presenta en lo relacionado con conceptos jurídicos, los cuales, poseen menos implicaciones valorativas, como ejemplo de ello, se encuentra el concepto de causalidad, ya que en materia penal y civil existen variadas concepciones de causalidad, una es la causalidad fáctica en el entendido de que el evento B haya sido causado por el evento A, otra concepción de causalidad es la jurídica, y de 
acuerdo a una de ellas, que el llamado but for test, el evento A fue causa del evento B, si y solo si, en caso de que el evento B no hubiera acaecido, el evento A tampoco hubiera tenido lugar.

Cuando un mismo concepto ha sido causa de diversas concepciones, es preciso entrar a analizar cada una de ellas, para determinar cuándo, de qué manera y en qué sentido los interlocutores que participan en el dialogo social, utilizan dicho concepto.

Desde el ámbito del derecho internacional, el concepto de análisis de contexto ha dado lugar a diversas concepciones dentro del discursos de la Fiscalía General de la Nación, y resulta de vital importancia analizar dichas concepciones para tener claridad acerca del significado y en que consiste la metodología de análisis de contexto, para entrar a determinar, si alguna de las diversas concepciones de dicha metodología, resulta ser la más apropiada para determinar cuál de dichas concepciones es la más apropiada de aplicar en el derecho penal interno colombiano.

\subsection{Análisis de contexto, designio común, empresa criminal conjunta, modus operandi, practica, patrón y situación}

La metodología de análisis de contexto, puede ser de gran ayuda, en el momento de estructurar, de una forma más fuerte a la más débil, la responsabilidad penal a los individuos dentro de su participación en una actividad penal en conjunto; dicha metodología surge como elaboración de los conceptos detallados, los cuales, han sido utilizados para fines similares en diversos ámbitos del derecho internacional.

\section{A. El concepto de designio común}

Este concepto fue utilizado por primera vez dentro del ámbito de la investigación de actividades delictuales, por parte de las comisiones y cortes militares creadas por los aliados después de su vitoria en la Segunda Guerra Mundial, sin embargo dicho concepto contaba con una gran trayectoria en el derecho penal inglés. Sin embargo, dentro del marco de la segunda postguerra se usó para acusar y condenar al personal que trabajaba en los campos de concentración, y a los adeptos al régimen nazi que habían incentivado las luchas y los adeptos en contra de los aliados. 
La responsabilidad penal derivada del concepto de designio común, exigía la existencia de evidencias de que el acusado era consiente, de que su conducta había contribuido a la perpetración del delito de alguna manera, aparte de ello se exigía un elemento físico, que se trataba de que la cooperación del acusado hubiera tenido un efecto real dentro de la comisión del delito. El problema con dicha teoría era que no se lograba diferenciar entre el delincuente y el cómplice, ya que todos los acusados eran considerados como partícipes en el delito en un mismo grado.

\section{B. El concepto de empresa criminal conjunta en la jurisprudencia de la Corte Penal Internacional para la antigua Yugoslavia}

La doctrina sobre empresa criminal conjunta fue utilizada por parte de la Corte Penal Internacional para la Antigua Yugoslavia y luego, por la Corte Penal Internacional para Ruanda, la cual, establece un modelo de responsabilidad penal personal, derivado de la comisión de un delito colectivo.

La Corte Penal Internacional para la Antigua Yugoslavia, diseñó el concepto del Empresa Criminal Colectiva en el caso Tadic, pues en dicho proceso la Sala de apelaciones de la Corte se refirió a las debilidades de la doctrina de designio común, debido a que sostuvo que el concepto de designio común se aplica a tres categorías diferentes de delitos colectivos.

La primera categoría, se refiere a casos en los cuales, todos los acusados tienen la misma intención de llevar acabo un designio penal común; la segunda categoría, se refiere a los casos atinentes a los campos de concentración, en los cuales, se exige que el acusado haya tenido participación activa, dicha participación se colige de la posición de autoridad que el sujeto posea y de las funciones específicas que cada acusado dentro del designio común criminal cumplía.

Asimismo, el elemento subjetivo abarca dos aspectos importantes que son, el reconocimiento por medio del maltrato de la naturaleza del sistema de represión y la intención de llevar a cabo el designio común, por medio del maltrato y de los abusos cometidos contra dichos 
prisioneros dentro de los campos de concentración, y este mismo elemento subjetivo se podía inferir también, respecto a la posición que el acusado tenía dentro del campo de concentración, y la tercera categoría, a casos en los cuales, uno de los perpetradores lleva a cabo un acto, que a pesar de salirse del designio común, es un consecuencia natural y previsible de haber realizado el designio común.

De las tres categorías, la última resulta tener mayor carácter debatible, porque de ella puede derivarse la responsabilidad penal de personas que han tenido una implicación remota con los hechos delictivos. Por ejemplo en el caso Tadic, el acusado fue condenado con base en la doctrina concerniente a esta categoría, en desacuerdo con lo determinado por la Sala de Primera Instancia, debido a que la sala de apelaciones condenó a Tadic, por el homicidio de cinco personas que fueron transportadas fuera de Jaskici, con igual grado de responsabilidad con el que fueron condenados quienes verdaderamente perpetraron el homicidio.

La sala de apelaciones argumentó, que se había logrado probar de que a pesar de que Tadic no había llevado a cabo físicamente el homicidio, sí compartía con los perpetradores la intención de transportar a las víctimas fuera de Jaskici, asimismo, la sala consideró que el homicidio de tales victimas durante dicha movilización fuera de Jaskici era previsible.

Esto significa, que el elemento subjetivo - intencional de la tercera categoría de la teoría del designio común, es diferente a las de las dos primeras categorías, ya que las dos primeras categorías exigen del acusado la intención de participar y de ejecutar o llevar a cabo el operativo criminal que es el propósito del grupo, y exigen que todos los participantes tengan la misma intención, en cambio, la utilización de la tercera categoría atribuye responsabilidad penal al participante en un crimen que caiga fuera del objetivo común, siempre y cuando se presenten las siguientes dos condiciones:

1. Que sea previsible que alguno de los miembros del grupo perpetre el delito que fue acaecido como parte de la empresa común; y 2. Que el acusado voluntariamente haya aceptado ese riesgo. 
Desde ese momento se habla de la doctrina de la empresa criminal colectiva, ya que esta misma doctrina fundamenta la imputación de delitos colectivos, cuando detrás de dichos delitos existe un plan colectivo o una política diseñada o implementada por individuos, que actúan en diferentes niveles y con diverso roles, donde cada uno de los cuales, contribuye de una manera particular para alcanzar el objetivo común.

La Corte Penal Internacional para la Antigua Yugoslavia, utiliza el concepto de empresa criminal colectiva para acusar e imputar responsabilidad penal a los autores intelectuales, es decir, políticos y militares de alto rango, que dentro de la posición de superiores jerárquicos, idearon la comisión de crímenes internacionales.

\section{El concepto de modus operandi, práctica y patrón}

La Corte Interamericana de Derechos Humanos ha utilizado dichas nociones para encontrar una base para imputar responsabilidad penal, y también para imputar responsabilidad internacional a los Estados miembros del Sistema Interamericano de Derechos Humanos, por haber cometido violaciones a los derechos humanos cometidas por parte de las autoridades estatales.

La base principal para imputar responsabilidad estatal, es la reconstrucción de ciertas maneras de actuar reiteradas por parte de las autoridades estatales, que da lugar a ciertas prácticas y patrones de comportamiento reconocidos públicamente y que se constituyen como violatorios de los Derechos Humanos.

En el caso Velásquez Rodríguez, la Corte Interamericana de Derechos Humanos, señaló que los conceptos de modus operandi, práctica y patrón, permiten imputar responsabilidad y condenar a un Estado por violaciones a los derechos humanos, a pesar de que no exista una evidencia concreta de ello, la Corte en tal sentido aclaró lo siguiente:

Cuando la existencia de tal práctica o política haya sido probada, es posible, ya sea mediante prueba circunstancial o indirecta, o ambas, o por inferencias lógicas pertinentes, 
demostrar la desaparición de un individuo concreto, que de otro modo sería imposible, por la vinculación que ésta última tenga con la práctica general. (Barbosa \& Bernal, 2015, p.51).

Para determinar la responsabilidad del Estado por una violación a los Derechos Humanos, es importante entrar a demostrar la existencia de un modus operandi, y que existe alguna clase de vinculación entre dicha violación a los derechos humanos y el modus operandi, práctica o patrón.

La metodología del contexto, posee un gran impacto sobre el derecho al debido proceso y es totalmente diferente al que debe utilizarse al interior de los Estados, para fundamentar la responsabilidad penal, en este sentido, la Corte Interamericana de Derechos Humanos aclaró lo siguiente:

Para un tribunal internacional, los criterios de valoración de la prueba son menos formales que en los sistemas legales internos. En cuanto al requerimiento de prueba, esos mismos sistemas reconocen gradaciones diferentes que dependen de la naturaleza, carácter y gravedad del litigio. (Barbosa \& Bernal, 2015, p.51).

Al mismo tiempo la Corte Interamericana de Derechos Humanos, determina lo siguiente:

La protección internacional de los derechos humanos no debe confundirse con la justicia penal. Los Estados no comparecen ante la Corte como sujetos de acción penal. El Derecho internacional de los derechos humanos no tiene por objeto imponer penas a las personas culpables de sus violaciones, sino amparar a las víctimas y disponer la reparación de los daños que les hayan sido causados por los Estados responsables de tales acciones. (Barbosa \& Bernal, 2015, p.51).

Dicha diferencia, se debe en cierta medida al propósito de aliviar los problemas que tiene el demandante para tener acceso a las pruebas dentro de un proceso a nivel internacional, al respecto, la Corte Interamericana de Derechos Humanos determina los siguiente: 
a diferencia del Derecho penal interno, en los procesos sobre violaciones de derechos humanos, la defensa del Estado no puede descansar sobre la imposibilidad del demandante de allegar pruebas que, en muchos casos, no pueden obtenerse sin la cooperación del Estado. (Barbosa \& Bernal, 2015, p.52).

La metodología basada en las nociones de modus operandi, práctica y patrón, se han utilizado por la Corte Interamericana de Derechos Humanos en casos como el de Loayza Tamayo, Castillo Páez, Blake, Masacre de Plan de Sánchez, Masacre de los 19 comerciantes, Mapiripán, Pueblo Bello, Ituango y La Rochela.

\subsubsection{El problema funcional}

Este problema hace referencia a la necesidad de esclarecer las funciones que cumple éste tipo de análisis, las cuales pueden llegar a ser una heurística dentro de la investigación penal, ser base para la imputación de responsabilidad penal, y ser sucedáneo de la prueba.

Desde un punto de vista analítico, se debe determinar cuál de estas tres funciones es la que la Dirección de Análisis y Contextos atribuye al análisis de contexto, y a nivel crítico normativo, se debe determinar cuál de etas funciones es la que corresponde al análisis de contexto dentro del marco del Estado de Derecho.

Pero desde una interpretación conjunta tanto de dicho Informe como de la Directiva 001 de 2012, se logra inferir que el análisis de contexto, se ha utilizado por parte de la Fiscalía General de la Nación, como una base para la atribución de responsabilidad penal o como una alternativa sucedánea de la prueba.

El Informe determina dentro de la primera fase del análisis de contexto, lo siguiente:

la delimitación de las situaciones (a investigar) puede provenir del análisis de un caso particular, a partir del cual se encuentren patrones comunes con otros, o que este 
ejemplifique un plan criminal y sea representativo de los patrones de conducta delictiva, características de una organización, alianza o red criminal. (Barbosa \& Bernal, 2015, p.58)

La reconstrucción de dichos patrones, se realiza por medio de la construcción del contexto, en el cual los hechos perpetrados tuvieron ocurrencia. De lo anterior, es importante destacar, que de conformidad con la Directiva 01 de 2012, el concepto de contexto se desarrolla de la siguiente manera:

Marco de referencia contentivo de aspectos esenciales, históricos y sociales, en el cual se han perpetrado delitos por parte de grupos criminales, incluidos aquellos en los que servidores públicos y particulares colaboran en su realización. Debe igualmente comprender una descripción de la estrategia de la organización delictiva, sus dinámicas regionales, aspectos logísticos esenciales, redes de comunicaciones y mantenimiento de redes de apoyo, entre otros. (Barbosa \& Bernal, 2015, p.58)

Los objetivos que se persiguen por medio de la formulación del contexto, de acuerdo al Directiva 01 de 2012, son establecer la verdad de los hechos acaecidos, evitar la repetición de los mismos, establecer la estructura de la organización criminal, definir los niveles de responsabilidad de los miembros que conforma la organización criminal y de sus colaboradores, articular los procesos internos de la Fiscalía para establecer patrones de conducta y cadenas de mando, y crear sistema de imputación penal que contemplen la posibilidad de determinar las responsabilidad penal de las organizaciones criminales y de los miembros que la componen.

La tarea de la formulación de contexto, suscita dudas acerca de la exigencia de pruebas sobre las responsabilidades individuales de los sujetos que posiblemente pueden ser vinculados a una investigación penal, la cual, debe ser guiada por el análisis de contexto, y una vez que sea formulado dicho contexto, para poder determinar la posible acusación de un individuo por el acaecimiento de un delito determinado, se debe probar la comisión de dicho delito por parte del individuo, y en caso de tratarse de un delito colectivo, el grado de participación de dicho individuo en tal delito, y ni el Informe ni la misma Directiva dan una conclusión coherente a esta discusión. 
Solo una respuesta afirmativa a dicho cuestionamiento, logra garantizar, que el análisis de contexto no llegue convertirse en un sucedáneo de la prueba. A nivel normativo, el análisis de contexto es una metodología adecuada para ser utilizada como heurística dentro de la investigación penal, debido a que la construcción de contextos, orienta a los investigadores por el buen camino para el recaudo de pruebas y de evidencias, y para lograr la identificación de responsables de hechos delictivos, y en lo que respecta a analizar el contexto desde la heurística, éste se convierte en una estrategia que favorece la celeridad y la eficiencia en la actuación de la administración de justicia.

La utilización del análisis de contexto como sucedáneo de la prueba y como fundamento para la imputación de responsabilidad penal, es contrario a la presunción de inocencia.

De acuerdo con el Artículo $4^{\circ}$., de la Constitución Política, "toda persona se presume inocente mientras no se la haya declarado judicialmente culpable", lo cual significa, que al sujeto al quien se le deba imponer una sanción se presume inocente, a menos que existan pruebas fehacientes que demuestren lo contrario.

La Sentencia C - 774 de 2001, de la Corte Constitucional, determina que la presunción de inocencia tiene el rango de derecho fundamental dentro de nuestro ordenamiento jurídico, y debido a que es considerado un derecho fundamental, establece que "el acusado no está obligado a presentar prueba alguna que demuestre su inocencia, y por el contrario ordena a las autoridades judiciales competentes la demostración de la culpabilidad del agente", lo cual, se puede lograr mediante evidencias apropiadas y convenientes dentro del proceso.

La Constitución Política de Colombia y la Jurisprudencia de la Corte Constitucional, determina que utilizar la investigación del contexto para imputar responsabilidad penal o como sucedáneo de la prueba, vulnera el derecho fundamental de la presunción de inocencia, como principio integrador del debido proceso.

El vincular a unas determinadas personas a una investigación penal, por medio de la construcción de un contexto, no revela al investigador la tarea de encontrar evidencias certeras 
acerca de la participación concreta de cada uno de los investigados dentro de los hechos punibles que se está investigando, y en el caso de que el ente investigador, no logre encontrar dicha evidencias, se debe seguir presumiendo como inocentes a los investigados.

Lo anterior significa, que la presunción de inocencia haría inadmisible que el análisis de contexto se pueda trasplantar desde el derecho internacional hacia el derecho interno, para que cumpla la misma función que cumple en el derecho internacional.

\subsubsection{El problema del trasplante}

El análisis de contexto es una metodología de investigación judicial para crímenes de alto impacto, la cual, ha sido trasplantada por parte de la Fiscalía General de la Nación al derecho interno, desde el ámbito del derecho internacional, pero se debe entrar a analizar si el hecho de realizar dicho trasplante resulta admisible para el derecho penal interno en Colombia.

En primer lugar, se debe analizar cuales debe ser las condiciones que deben reunir los marcos de origen y de destino de los conceptos jurídicos, para que dicho trasplante sea admisible, en segundo lugar, si dichos marcos de origen y de destino, del análisis de contexto, reúnen dichas condiciones, de tal modo que el trasplante de dicho concepto desde aquel hasta este, se pueda catalogar como admisible.

\subsection{Trasplantes y migraciones de conceptos jurídicos}

Los trasplantes y las migraciones de conceptos jurídicos es una de las tantas manifestaciones de sistemas jurídicos que más se han acentuado con el concepto de globalización. Frente a cada trasplante, se debe analizar, si existe alguna razón que justifique el hecho de que un concepto jurídico o una metodología jurídica, que forme parte del análisis de contexto, migre de un sistema jurídico a otro; y por otra parte, si dicha migración es apropiada y justificada. 
Para poder justificar el trasplante de un concepto o de una metodología, esto depende de dos factores, el primero, debe analizar si existe una justificación en abstracto para el uso de dicho concepto o metodología, es decir, este aspecto se refiere a si el análisis de contexto se encuentra justificado en abstracto.

El segundo factor, determina si existe una justificación concreta para tomar el concepto de que se trate desde un sistema de derecho internacional y trasplantarlo a otro sistema jurídico, durante un tiempo determinado, y en un área del derecho en particular, por ejemplo, trasplantar la metodología del análisis de contexto desde el ámbito de derecho internacional hasta el derecho penal interno colombiano.

Los conceptos jurídicos, tales como el análisis de contexto, pueden tomarse prestados y trasplantarse de un sistema jurídico a otro. Existe de alguna manera una correlación entre la justificación en abstracto para el uso del concepto jurídico y la justificación concreta para su migración. La razón válida para trasplantar conceptos jurídicos, proviene de su racionalidad y de su legitimidad intrínseca.

Sin embargo, ni esta justificación en abstracto ni el hecho de que un uso concreto del concepto jurídico en el contexto original resulte plausible, constituyen razones, que hagan admisible su migración. Tanto el derecho constitucional como el derecho penal interno, dentro de los cuales se enmarca el uso del análisis de contexto por parte del Fiscalía General de la Nación, son una expresión de la identidad nacional.

El derecho en sí, se encuentra arraigado en las actitudes y en el bagaje jurídico de los servidores públicos y en los abogados de cada cultura, y esos mismos elementos, determinan, el significado de las reglas jurídicas. Los doctrinantes más importantes, explican que esta clase de trasplantes, son contrarios a la democracia y al carácter limitado que el ejercicio del poder juridicial tiene dentro de un Estado de Derecho, debido a que los trasplantes jurídicos favorecen las ideologías extranjeras, y permiten que los jueces manipulen a su antojo el contenido y el alcance de las normas constitucionales. Dicha posibilidad, pone en riesgo la integridad del 
proceso judicial, que es la base del Estado de Derecho, y la esencia de la democracia, por la cual, las normas de un Estado debe representar la voluntad popular.

Otros doctrinantes, determinan que los métodos y los conceptos de unos sistemas jurídicos pueden tomarse prestados y adaptarse a otros contextos políticos, sociales, culturales y jurídicos, siempre y cuando, la función que tales conceptos estén llamados a cumplir en los contextos de recepción, sea similar a la que tienen en los contextos jurídicos de origen.

De lo anterior se colige, que las razones que justifican el uso del análisis de contexto en abstracto no justifican su trasplante desde su jurisdicción de origen hasta una área específica de otro sistema jurídico, debido a que un trasplante estará justificado desde dos circunstancias, tales como, primera, si el objeto de trasplante puede cumplir en los dos contextos la misma función o una función análoga, y segundo, si en el caso de que lo anterior no se pueda lograr, el objeto de trasplante se adapta para que dentro del marco de recepción cumpla una función apropiada, que no lo convierta en un elemento exógeno, o que sea incompatible con el resto de los elementos del sistema jurídico al cual se incorpora.

\subsection{El marco de origen y el marco de recepción de la investigación en contexto}

Es importante analizar la función que la metodología del análisis de contexto en el marco de origen y en el marco de recepción. El marco de origen del análisis de contexto, es el Derecho Internacional, y en particular, el Sistema Interamericano del Derechos Humanos, y dicha metodología es utilizada, para atribuir responsabilidad colectiva al Estado por la violación de derechos humanos y para esclarecer la verdad de los hechos perpetrados que provocaron dicha violaciones.

Desde la función mencionada, se puede determinar, que el marco de origen del análisis de contexto sirve no solo para orientar la investigación judicial sino también, como sucedáneo de prueba. La finalidad de los sistemas internacionales de protección de los derechos humanos es holística, y esto pretende prevenir, la perpetración de vulneraciones a los derechos humanos, por parte de los mismos Estados, y buscar fórmulas para reparar los derechos de las víctimas. 
Dentro de éste parámetro, las exigencias del debido proceso, se logran interpretar de manera más laxa, ya que es importante analizar que dentro de un sistema de derecho internacional, tal como es el Sistema Interamericano de Derechos Humanos, las sanciones tienen un contexto político y ejemplarizante, que va más allá de su contexto jurídico.

Dichas características no se presentan dentro del marco del análisis de contexto, debido a que su utilización por parte del Fiscalía General de la Nación para lograr la imputación de responsabilidad penal, y dentro de éste mismo ámbito, la finalidad de dicha metodología de investigación, es constituir la base para la acusación penal de un individuo, tomando como base las pruebas fehacientes de su participación dentro del operativo criminal ya sea en calidad de autor o en calidad de coautor.

Lo anterior establece que se trata de desvirtuar la presunción de inocencia que la Constitución Política establece a favor de cada sujeto que se investiga, el carácter de derecho fundamental de dicha presunción, no permite su interpretación de manera laxa, por lo tanto, dentro del marco de arribo, el análisis de contexto debe adaptarse, y puede ser utilizado como una heurística para la investigación penal, pero no puede usarse como sucedáneo de prueba.

La utilización de análisis de contexto como sucedáneo de prueba, no sólo vulneraria la Constitución Política, sino, todo un cuerpo normativo de derecho internacional de los derechos humanos, el cual, determina el respeto del derecho fundamental al debido proceso desde el ámbito del derecho penal.

\subsection{La competencia de los órganos judiciales colombianos para acusar, condenar y sancionar crímenes de lesa humanidad}

Colombia está obligada a eliminar la impunidad, especialmente en el caso de las violaciones a los derecho humanos. En consecuencia y para garantizar el cumplimiento de los estándares internacionales relativos a la investigación, juzgamiento y sanción de las graves violaciones a los derechos humanos, los funcionarios públicos deben acudir no solo a: 
La normatividad interna sino aquella integrada en el bloque de constitucionalidad y las decisiones proferidas por organismos internacionales, tales como el Comité de Derechos Humanos, la Comisión Interamericana de Derechos Humanos y la Corte Interamericana de Derechos Humanos. (Forer, López Díaz, Errandonea, Cardona \& González, 2010, p. 47).

Lo anterior, corresponde al desarrollo del "bloque de constitucionalidad", dentro de la jurisprudencia de la Corte Constitucional Colombiana, y por otra parte, en principio, se deberán imputar delitos nacionales, que retomen la descripción de los crímenes internacionales, independiente de su nomen iuris, y siempre que respeten el principio de proporcionalidad de la pena.

Esto quiere decir, que en la sentencia o en la imputación, se deberá mencionar la característica internacional del crimen y describir sus elementos, su contexto, las características de la población civil y la generalidad o la sistematicidad, para poder satisfacer los postulados de la verdad, justicia, reparación y garantías de no repetición a las víctimas, que han sido desarrollados por el Derecho internacional y nacional.

Lo anterior va acorde con la jurisprudencia de la Corte Interamericana de Derechos Humanos, conforme a la cual, en casos en los cuales, se constata que a nivel interno no se imputó el delito que correspondería al Derecho Internacional, y sin embargo los hechos aun así, no quedaron en la impunidad, tal corporación ha reconocido el valor de las condenas de derecho nacional de la siguiente manera:

La disparidad en la calificación de los hechos a nivel interno e internacional se ha visto reflejada en los mismos procesos penales. No obstante, la Corte reconoce que la detención ilegal y arbitraria, tortura y desaparición forzada de las víctimas no ha quedado en la total impunidad mediante la aplicación de otras fuentes penales. (Forer, López Díaz, Errandonea, Cardona \& González, 2010, p. 47).

Lo anterior quiere decir, que el hecho de no imputar el nomen iuris internacional no se constituye en una violación del Derecho Internacional. 
En el caso Neptune contra Haití, de la Corte Interamericana de Derechos Humanos, declaró violado el artículo $9^{\circ}$., de la Convención Americana de Derechos Humanos que establece el principio de legalidad y no de retroactividad, debido a que la víctima había sido acusada de un crimen de masacre que no se encontraba tipificado en el ordenamiento penal interno. Pero en este caso, si bien la masacre constituye un crimen internacional, es decir, una grave violación a los derechos humanos o un crimen de lesa humanidad, la Corte protegió el principio de legalidad, de la siguiente manera:

(...) Con respecto al principio de legalidad en el ámbito penal, (...) la elaboración de los tipos penales supone una clara definición de la conducta incriminada, que fije sus elementos y permita deslindarla de comportamientos no punibles o conductas ilícitas sancionables con medidas no penales. (...)En un sistema democrático es preciso extremar las precauciones para que las sanciones penales se adopten con estricto respeto a los derechos básicos de las personas y previa una cuidadosa verificación de la efectiva existencia de la conducta ilícita. (...) En este sentido, corresponde al juez penal, en el momento de la aplicación de la ley penal, atenerse estrictamente a lo dispuesto por esta y observar la mayor rigurosidad en (la adecuación) de la conducta de la persona incriminada al tipo penal, de forma tal que no incurra en la penalización de actos no punibles en el ordenamiento jurídico. (Forer, López Díaz, Errandonea, Cardona y González, 2010, p. 48).

Con base en los anteriores argumentos, se puede manifestar que el Estado está en la obligación de investigar, juzgar y sancionar a los responsables de graves violaciones a los derechos humanos, es decir, que el Estado deberá perseguir tales conductas de forma tal que no puedan quedar en la impunidad, por otra parte, para la Corte Interamericana de Derechos Humanos, es necesario que los tipos penales se encuentren previa y expresamente definidos en el orden interno, por lo tanto, siempre que se condene por crímenes que no satisfagan el principio de legalidad en sentido estricto, el Estado compromete su responsabilidad internacional.

Es importante tener en cuenta, que si el derecho penal interno, contiene tipos penales que describen a cabalidad la situación del hecho de la que se trate, así como una pena razonable y proporcional a la entidad del mismo, se debe imputar y sancionar con base en la legislación 
nacional; además, si tal conducta reviste a la luz del derecho internacional el carácter de crímenes de lesa humanidad, necesariamente habrá de desarrollarse en el texto de la sentencia y resaltarse en el curso del proceso, dentro del cual, se debe explicitar sus elementos, características, sistematicidad o generalidad.

Como ejemplo del anterior, podemos citar el auto de legalización de cargos del Tribunal de Justicia y Paz en el caso El Iguano, así como en el auto de la Corte que resolvió el recurso de apelación interpuesto contra esta, en el cual, se reconoció lo siguiente:

Para conseguir los fines trazados por la cúpula de las autodefensas - acabar con la subversión y sus auxiliadores y limpieza social de la región - ejecutaron conductas consideradas como graves a la luz del Derecho Internacional Humanitario como homicidio en persona protegida, desplazamientos forzados, tortura en persona protegida, cobros de impuestos ilícitos, etc., así como delitos contra la población civil de manera sistemática o generalizada que bien pueden ser calificados como punibles de lesa humanidad. (Forer, López Díaz, Errandonea, Cardona y González, 2010, p. 49 - 50).

En la misma providencia, la Corte Suprema de Justicia determinó lo siguiente:

La declaración de crímenes de lesa humanidad es un acto de connotación judicial que bien puede hacerlo el funcionario de la Fiscalía General de la Nación que cumple el papel de acusador, o bien juez de conocimiento. En suma, los homicidios agravados y en persona protegida en los que incurrió el acusado directamente o por intermedio del aparato organizado de poder (autodefensas), mal llamadas acciones de "limpieza social", que revisten las características de ser conductas sistemáticas, generalizadas, que tuvieron por fin acabar con personas de la población civil, expendedores de droga, etc., ciertamente que deben ser considerados como crímenes de lesa humanidad, causados en once "acciones de limpieza social" (típicos asesinatos) de que tratan los 50 atentados contra la vida. (Forer, López Díaz, Errandonea, Cardona y González, 2010, p. 50). 
En dicho punto, la Corte señaló que la declaratoria de una conducta como crimen de lesa humanidad, parte de resaltar la magnitud del daño que fue causado y la entidad de los delitos que fueron cometidos, tiene importantes efectos jurídicos, como son los siguientes:

Son crímenes imprescriptibles. Son imputables al individuo que los comete, sea o no órgano o agente del Estado. Tampoco, puede ser eximido de responsabilidad penal por el hecho de haber actuado en cumplimiento de órdenes de un superior jerárquico: esto significa, que no se puede invocar el principio de la obediencia debida para eludir el castigo de estos. (Forer, López Díaz, Errandonea, Cardona y González, 2010, p. 50).

De acuerdo a lo anterior, se comparte totalmente la posición de la Corte Suprema de Justicia en relación con las consecuencias de declaratoria de un delito como crimen de lesa humanidad, como son, la imprescriptibilidad e inoperancia de la causal de exclusión de la responsabilidad penal relativa a haber actuado en cumplimiento de órdenes de un superior jerárquico.

Dichas características no violan el principio de legalidad, debido a que se persigue y se condena por una conducta típica prevista en el derecho nacional, pero debido a su relevancia como crimen de derecho internacional, se le asignarán tales efectos.

En relación con la característica de imprescriptibilidad para esta clase de conductas, la Corte Constitucional determinó que "en armonía con el Tratado de Roma, en el caso de determinadas conductas que constituyen delitos de lesa humanidad la acción penal es imprescriptible".

Dicha postura no viola el principio de legalidad por cuanto es con observancia a este que se imputa, se condena, se investiga y se sanciona al responsable de los crímenes cometidos, por lo tanto, las exigencias del principio de legalidad en relación con la tipicidad de la conducta y de la pena a imponer estarían totalmente satisfechas. 
Finalmente, el no reconocer el actuar en cumplimiento de una orden como causal de exoneración de punibilidad es totalmente acorde con la jurisprudencia penal internacional, por otra parte, tal principio hace parte del derecho consuetudinario, tanto los artículos 8 y 10 de la Ley del Consejo de Control No. 10, 7.4., del Estatuto del Tribunal Penal Internacional para ex Yugoslavia, 6.4., del Estatuto del Tribunal Penal Internacional para Ruanda, así como el artículo 33 del Estatuto de Roma, los cuales, determinan claramente que quien actúa en cumplimiento de una orden del superior y con ellos comete crímenes de derecho internacional deberá responder penalmente.

\subsection{Características de los delitos de carácter permanente, como el delito de desplazamiento forzado por la violencia en Colombia}

En relación con los delitos de ejecución permanente, existe una gran discrepancia en relación con la aplicación de tipos penales posteriores al comienzo de la ejecución de los crímenes de que se trate.

Esto significa, que para algunos autores se expresa lo siguiente:

El tipo penal de desaparición forzada de personas puede ser imputado aun cuando al momento de la privación de la libertad tal tipo penal aún no había sido sancionado, dado que precisamente el injusto continúa y permanece incluso tras la entrada en vigencia. (Forer, López Díaz, Errandonea, Cardona y González, 2010, p. 52).

Para otros autores, ello constituirá una aplicación retroactiva de la ley penal y una violación del principio de legalidad, inocencia y seguridad jurídica.

Es importante analizar, que en lo que respecta a los delitos de ejecución permanente como es el caso de los crímenes de lesa humanidad, aun cuando el comienzo de la consumación fue previo a la tipificación a nivel nacional o interno, se debe imputar la misma siempre y cuando se continúe consumando el delito luego de la existencia del tipo penal a nivel interno. Dicho razonamiento no riñe con el principio de legalidad de la ley penal, a pesar de que se 
hubiese comenzado a consumar con anterioridad a la tipificación interna, y en este mismo sentido, se han pronunciado los tribunales nacionales internacionales.

Finalmente, cuando se hubiese terminado de consumar con anterioridad a la tipificación, no es necesario acudir a la tipificación posterior, siempre y cuando los hechos no queden en la impunidad, la pena aplicada sea proporcional al daño causado y se explicite el carácter de lesa humanidad del crimen que se haya cometido.

\subsubsection{Crímenes de lesa humanidad y el delito de desplazamiento forzado}

En la experiencia de los Tribunales ad hoc, un ejemplo básico de la participación involuntaria de civiles es el delito de desplazamiento forzado por la violencia que se da a gran escala y que es involuntaria. Este delito y a la vez fenómeno es considerado como inevitable en cualquier conflicto, debido a la necesidad humanitaria de evacuar a los civiles de la zona de conflicto y su tendencia a buscar protección fuera del campo de batalla.

Para algunos casos previos al Tribunal Penal para la Antigua Yugoslavia, los fallos de los jueces reflejan la naturaleza de muchos conflictos contemporáneos, los cuales, se basan en un plan específico de líderes civiles y militares para desplazar a grandes porciones de la población civil por motivos éticos, religiosos, políticos, etc., y dependiendo de las circunstancias concretas de cada caso, y aparte de la posibilidad de que equivalga a un crimen de guerra el desplazamiento forzado de civiles, da lugar a responsabilidad penal individual por uno o más crímenes de lesa humanidad.

Es importante tener en cuenta los Estatutos del Tribunal Penal Internacional de Ruanda y del Tribunal Penal para la Antigua Yugoslavia, los cuales, definen de manera concreta algunos crímenes como de lesa humanidad y entre ellos tenemos los siguientes:

Asesinato, exterminio, esclavitud, deportación, encarcelamiento, tortura, violación, persecución por motivos políticos, raciales y religiosos y otros actos inhumanos. La deportación se define como el desplazamiento forzado de personas fuera de las fronteras de 
un Estado (o cuasi Estado), incluso en ausencia de la intención de desplazar a las personas de forma permanente. (Acquiaviva, 2011, p.15)

En este orden de ideas, la deportación como crímenes de lesa humanidad, es similar al correspondiente crimen de guerra, y los requisitos generales para cada uno de estos delitos, y que difieren entre el Tribunal Penal Internacional para la Antigua Yugoslavia y el Tribunal Penal Internacional de Ruanda, determinan su principales diferencias.

Por otra parte, la expresión "otros actos inhumanos", es una clausula general que abarca los graves actos criminales que no se encuentran taxativamente enumerados en el Artículo $5^{\circ}$., del Estatuto del Tribunal Penal Internacional para la Antigua Yugoslavia o en el Artículo $3^{\circ}$., del Estatuto del Tribual Penal Internacional de Ruanda.

En cierto sentido, la jurisprudencia internacional ha aclarado que los actos de traslado forzoso de la población civil, pueden llegar a ser lo suficientemente graves, para llegar a constituir otros actos inhumanos, pero lo más importante es que los crímenes de lesa humanidad incluyen la persecución, que de alguna manera forma parte del crimen, la cual, abarca un acto subyacente que niega un derecho humano fundamental y que se asocia a una intención discriminatoria.

\subsubsection{Diferencia entre deportación y traslado forzoso de la población civil en la jurisprudencia del Tribunal Penal Internacional para la Antigua Yugoslavia}

En la Jurisprudencia del Tribunal Penal Internacional para la Antigua Yugoslavia, ha tratado de distinguir entre deportación y traslado forzoso de la población civil. Por su parte la Cámara de Apelaciones del Tribunal Penal Intencional para la Antigua Yugoslavia, sostuvo en Stakic, que la deportación requiere "el desplazamiento forzado de personas mediante la expulsión, u otras formas de coacción, de la zona en la que están legítimamente presentes, a través de una frontera estatal de jure o, en determinadas circunstancias, una frontera de facto". (Acquiaviva, 2011, p.20). 
Por su parte, un traslado forzoso de presenta cuando hay un desplazamiento forzado de personas dentro del territorio de un Estado. La deportación tuvo sus orígenes como un crimen de guerra y luego se extendió a los crímenes de lesa humanidad a fin de proteger a los civiles de la misma nacionalidad que el autor, y la distinción entre los dos actos se aplica tanto a los crímenes de guerra como a los crímenes de lesa humanidad.

Por otro lado, la Cámara de Apelaciones del Tribunal Penal para la Antigua Yugoslavia señaló que "bajo ciertas circunstancias, el desplazamiento a través de una frontera de facto puede ser suficiente para equivaler a deportación”. (Acquiaviva, 2011, p.21)

Cuando la frontera de facto se asemeja a una frontera legal, se configura la deportación y la conducta se define como traslado forzoso y dado que ni el Tribunal penal para la Antigua Yugoslavia ni otros tribunales han resuelto dicho punto, es difícil establecer dentro de un conflicto armado entre dos partes, en episodio de desplazamiento caería bajo la definición de deportación o de traslado forzoso, pero se han elaborado algunas hipótesis.

Finalmente, la deportación ocurre cuando se cruza una frontera reconocida oficialmente y por el otro lado y según la jurisprudencia del Tribunal Penal Internacional para la Antigua Yugoslavia, el traslado forzoso, se presenta cuando una persona es desplazada a un pueblo diferente, dentro del mismo lado de la línea de confrontación entre las partes en conflicto.

\subsection{Régimen probatorio para los crímenes de lesa humanidad perpetrados en Colombia}

Dentro de la legislación penal colombiana, es necesario entrar a probar la ocurrencia de un crimen de lesa humanidad, dentro de los casos y para los efectos que establece la Constitución y la Ley.

Al respecto, podemos citar el Acto Legislativo No. 01 de 2009, el cual, menciona la existencia de los crímenes de lesa humanidad en diferentes aspectos, tales como la entrega de avales a candidatos políticos, dentro de la contratación estatal, en el acceso a los cargos públicos, entre otros muchos casos. 
En el caos de la aplicación del principio de oportunidad, para que proceda la existencia de un crimen de lesa humanidad, se debe demostrar que el procesado no haya cometido un crimen de lesa humanidad o de alto impacto para la comunidad nacional e internacional.

En estos casos, la normatividad interna, reenvía al orden jurídico internacional, para dotar de contenido y alcance un concepto jurídico, y se deberá acudir más exactamente al Artículo $7^{\circ}$., del Estatuto de Roma de la Corte Penal Internacional, por cuanto esta misma disposición vincula no solamente al Estado Colombiano, sino que además refleja el estado actual de la noción de "crimen de lesa humanidad". Por otra parte, es importante determinar si tanto los jueces como los fiscales, en materia penal, deben aplicar el concepto de "crímenes de lesa humanidad", que es propio del derecho penal internacional, y en cuáles efectos lo debe hacer.

De acuerdo con Ramelli (2011), una primera respuesta al anterior cuestionamiento, le niega toda importancia al concepto de "crímenes de lesa humanidad", dentro de la investigación de asuntos penales en Colombia, por cuanto:

1) se trata de una categoría que debe ser aplicada únicamente por fiscales y jueces penales internacionales, en sus respectivos ámbitos competenciales; 2) determinados comportamientos que, según el Estatuto de Roma de la CPI, configuran crímenes de lesa humanidad (verbigracia el exterminio, la persecución y el apartheid), no encuentran parangón en la ley 599 de 2000; 3) otras conductas que, por el contrario, sí aparecen tipificadas en el actual Código Penal (por ejemplo, desaparición forzada, tortura, violación, etcétera), si bien, prima facie, encuadran dentro de aquello que se califica como crimen de lesa humanidad, carecen de algunos elementos definitorios internacionales de los de aquéllos, en especial, masividad, generalidad, sistematicidad y “conocimiento del ataque”. En pocas palabras, según este planteamiento, los fiscales y jueces penales internos no pueden hacer las veces de sus pares internacionales. (Ramelli, 2011, p.295) 
Pero al respecto existe una segunda tesis, que es contraria a la anterior, en la cual, Ramelli (2011), determina lo siguiente:

... que los fiscales y jueces penales internos pueden emplear automáticamente y sin referencia alguna a la legalidad interna, el artículo $7^{\circ}$., del Estatuto de Roma del Corte Penal Internacional, por cuanto él constituye derecho consuetudinario. Tal fórmula, según Werle, es acogida por sistema del common law, donde la punibilidad puede "fundamentarse no sólo en normas escritas, sino también en normas no escritas (consuetudinarias)". (Ramelli, 2011, p.295)

Lo anterior, determina que a una persona se le podría imputar la comisión de un crímenes de lesa humanidad previsto en el Estatuto de Roma, y que ni siquiera estuviera tipificado en el Código Penal Colombiano (verbigracia exterminio, persecución, etcétera). Tal postura se halla fundamentada en el llamado "bloque de constitucionalidad", y que de imputársele de ese modo a dicha persona dicho crimen, se desconocería el principio de legalidad penal, y se pasaría por alto que estamos frente a normas de carácter internacional non - self - executing, es decir, disposiciones que deben ser desarrolladas por los respectivos legisladores penales internos, en particular en lo referente al quantum de la pena.

Una tercera tesis, que sería la intermedia, determina de conformidad con Ramelli (2011), lo siguiente:

... los fiscales y jueces penales colombianos pueden acudir, en cuanto valioso criterio relevante de interpretación, al artículo $7^{\circ}$, , del Estatuto de Roma del Corte Penal Internacional, con el propósito de contextualizar la comisión de determinados comportamientos, en especial, a efectos de: 1) lograr construir una verdad histórica; 2) buscar la puesta en marcha de mecanismos adecuados de reparación de las víctimas; 3 ) evitar que se cumplan las condiciones de admisibilidad de un caso ante la Corte Penal Internacional (artículo 17 del Estatuto de Roma); 4) comprender la comisión de un determinado crimen dentro de su verdadero contexto, y no simplemente como un delito 
común; y 5) en últimas, combatir la impunidad en casos particularmente graves en términos de afrenta contra la dignidad humana.(Ramelli, 2011, p.296).

Es decir, que para la tercera tesis, se da por aceptada de que no se pueden imputar cargos directamente por la comisión de un crimen de lesa humanidad, por cuanto el Código Penal Colombiano, no tiene un capitulo que regule dichos crímenes como bien jurídicamente tutelado, se pueden formular cargos pero solamente por delitos comunes, por cuanto incluso aquellos de la Ley 599 de 2000, que figuran en el listado del Artículo $7^{\circ}$.del Estatuto de Roma (verbigracia desaparición forzada, desplazamiento forzado, tortura, violación, etcétera), carecen de algunos elementos definitorios, que son propios de la legalidad internacional, como por ejemplo, la masividad, sistematicidad, generalidad, y conocimiento del ataque, pero esto no obsta para que las labores de investigación, al igual que el adelanto del juzgamiento para dichos crímenes debe orientarse de conformidad con los parámetros fijados por la legalidad internacional.

Lo anterior significa, que aunque formalmente se procese y se termine condenando a un individuo por la comisión de un delito común, materialmente, dicha conducta delictiva, se puede inscribir en un ataque masivo o sistemático contra la población civil con conocimiento de dicho ataque.

Por medio de la tesis intermedia, el juez penal interno, no asume las funciones de un juez internacional, pero se sirve de las categorías jurídicas empleadas por aquel, y esto conducirá a llevar una investigación de forma más amplia y con resultados mucho más profundos, es decir, que no es igual investigar un caso de homicidio agravado como un delito común, que hacerlo desde la perspectiva de un crimen de lesa humanidad.

Es decir, en el momento en que el investigador tiene en mente que se encuentra ante un crimen de carácter internacional, su labor se orientará a establecer quién es el responsable directo del crimen, sino además averiguará si existía un plan o una política para atacar a determinado grupo social (verbigracia sindicalistas, defensores de derechos humanos, etcétera), y si dentro de dicho contexto, fue ejecutado dicho crimen. 
Dentro de tal postura, el fiscal va mucho más allá del caso en concreto que se le presenta, prima facie, como un hecho aislado, para tener la posibilidad de dimensionarlo en su verdadero contexto, lo cual, lo conducirá a hallar a los máximos responsables de la elaboración del plan o de la política de ataque contra el grupo.

En síntesis, para Ramelli (2011), la tercera tesis presenta las siguientes ventajas:

1) respeta el principio de legalidad penal; 2) da efectividad al bloque de constitucionalidad; 3) evita que el juez interno asuma competencias propias de los jueces penales internacionales; y 4) permite al operador jurídico interno servirse de categorías internacionales a efectos de adelantar, de manera más integral, una investigación por violaciones graves a los derechos humanos. Lo anterior resulta de gran utilidad en el ámbito de aplicación la Ley de Justicia y Paz. (Ramelli, 2011, p.297)

A través del desarrollo del proceso de Justicia y Paz, la Unidad Nacional de Fiscalías para la Justicia y Paz, (UJP), se enfrenta a la judicialización de diferentes procesos, con el fin de estudiar y resolver casos de crímenes de alta complejidad, de carácter masivo y por la calidad de los victimarios de estos mismos hechos.

En este momento se encuentran más de 4.300 postulados en el proceso de justicia y paz; más de 330.000 delitos que han sido documentados por la Fiscalía y más de 69.000, que comprenden delitos con características de crímenes de lesa humanidad, homicidios, hurtos, falsedades materiales, entre otros.

En relación con las cifras anteriores, se analiza que las autoridades judiciales competentes, dentro de todo el proceso de justicia y paz que se ha venido desarrollando en Colombia, han logrado solamente tres condenas en los seis años de existencia de todo el proceso de paz.

Desde la creación de la Ley de Justicia y Paz, o Ley 975 de 2005, y de la creación de las instituciones para su implementación, de conformidad con Forer A. y López Díaz, C., han sido 
tres, las fuentes principales, mediante las cuales se ha marcado el derrotero del proceso y se han llenado los vacíos del procedimiento:

i) Los decretos reglamentarios del Gobierno Nacional con el fin de facilitar la implementación normativa de dicha ley, ii) la Jurisprudencia, tanto de la Corte Constitucional como de la Sala de Casación Penal de la Corte Suprema de Justicia que actúa como tribunal de segunda instancia en el proceso de Justicia y Paz; y, iii) las directrices de la Unidad Nacional de Fiscalías para la Justicia y la Paz (memorandos y circulares). (Forer \& López, 2011, p. 230)

Tanto la jurisprudencia como las directrices de la Unidad, han buscado estrategias para solucionar el problema de la masividad en lo referente a autores y a conductas punibles, como por ejemplo, la medida de la imputaciones parciales como método para dinamizar el proceso, en tanto que las segundas, se han orientado hacia la priorización, en relación con las actividades de investigación de conductas punibles de su competencia.

Dentro de la elaboración de las directrices de la Unidad Nacional de Fiscalías para la Justicia y la Paz, se halla la estrategia de priorización de delitos, la cual, se enmarca en diversos escritos y memorandos, de forma tanto expresa como tácita para dar prelación a la investigación de uno u otro delito en particular, de ésta misma manera, se demostrará que hasta el momento, la estrategia mencionada no se ha visto reflejada en las acusaciones ni en las condenas proferidas dentro del marco del proceso de justicia y paz.

\subsection{El Proceso Especial de Justicia y Paz en Colombia}

Posteriormente a la Guerra de Independencia, ha sido demasiados los enfrentamientos bélicos que ha sufrido el país en su vida como República, por ejemplo, en la alborada del siglo XX, tenemos la llamada "Guerra de los Mil días", que enfrentaron a liberales y conservadores, la cual, se constituye como un antecedentes importante dado que serían sus mismos actores, quienes se enfrentarían durante el periodo de la violencia acaecida a partir de 1948, con un hito de la memoria nacional, como fue el asesinato del caudillo Jorge Eliecer Gaitán. 
A partir de dichos enfrentamientos, surge la constitución de las guerrillas liberales, que se constituyen, de acuerdo con Forer y López Díaz (2011), en lo siguiente:

grupos armados que tras la consecución de la paz pactada entre los partidos liberal y conservador con el acuerdo del Frente Nacional, devendrían en nuevas formas de violencia guerrillera, esta vez, los grupos marxistas de los años sesentas. (Forer \& López, 2011, P. 232)

Como reacción a las mismas, y bajo el auspicio de grupos estatales, los años ochenta significaron el nacimiento del fenómeno paramilitar, cuyo poder se extendió a lo largo del territorio colombiano, generando una gran cantidad de inmensurables atrocidades.

Dentro del auge del fenómeno del paramilitarismo en Colombia, “el 15 de julio de 2003, el Gobierno Nacional y las Autodefensas Unidas de Colombia (AUC), suscribieron el "Acuerdo de Santa Fe de Galito para contribuir con la Paz de Colombia”, para iniciar con ello el proceso de desmovilización de ése grupo.

Para darle a este grupo un respaldo que fuera más allá del tema político y en desarrollo del acuerdo con los grupos que se encuentran en proceso de desmovilización, el Gobierno Nacional, impulsó en el Congreso de la República una legislación que brindara seguridad jurídica a la negociación, de tal forma que el día 25 de julio de 2005 fue promulgada a la Ley 975 de 2005, "Por la cual se dictan disposiciones para la reincorporación de miembros de grupos armados organizados al margen de la ley que contribuyan de manera efectiva a la consecución de la paz nacional y se dictan otras disposiciones para acuerdos humanitarios”.

El articulado de esta ley comprende todo el procedimiento penal mediante el cual, son desmovilizadas todas las personas pertenecientes a los Grupos Armados al Margen de la Ley (GOML), y las cuales, han sido postuladas por parte del Gobierno Nacional para obtener los beneficios que la misma ley prevé, como son una pena alternativa que oscila entre los cinco y los ocho años. 


\subsection{Políticas de priorización en el Proceso Especial de Justicia y Paz en Colombia}

Es importante destacar, la forma en la que se realiza la investigación y el juzgamiento para los crímenes de lesa humanidad perpetrados en Colombia, por medio de la Sentencia No. 110012252000201400027 del Tribunal Superior de Bogotá, Sala de Justicia y Paz, en lo que respecta al análisis criminal holístico, que debe ser necesariamente efectuado para estas conductas.

Artículo 4. La investigación y el juzgamiento en el proceso penal especial de justicia y paz. En procesos penales especiales de justicia y paz, la investigación y el juzgamiento de los casos deberán tener en cuenta el contexto, la gravedad y representatividad de los hechos, el grado de afectación a los distintos bienes jurídicos, el grado de responsabilidad del presunto responsable y la configuración de un patrón de macro-criminalidad.

Artículo 15. Definición de contexto. Para efectos de la aplicación del procedimiento penal especial de justicia y paz, el contexto es el marco de referencia para la investigación y juzgamiento de los delitos perpetrados en el marco del conflicto armado interno, en el cual se deben tener en cuenta aspectos de orden geográfico, político, económico, histórico, social y cultural. Como parte del contexto se identificará el aparato criminal vinculado con el grupo armado organizado al margen dela ley, y sus redes de apoyo y financiación.

Artículo 16. Definición de patrón de macro-criminalidad. Es el conjunto de actividades criminales, prácticas y modos de actuación criminal que se desarrollan de manera repetida en un determinado territorio y durante un período de tiempo determinado, de los cuales se pueden deducir los elementos esenciales de las políticas y planes implementados por el grupo armado organizado al margen de la ley responsable de los mismos. La identificación del patrón de macro-criminalidad permite concentrar los esfuerzos de investigación en los máximos responsables del desarrollo o, realización de un plan criminal y contribuye a develar la estructura y modus operandi del grupo armado organizado al margen de la ley, así como las relaciones que hicieron posible su operación. 
La identificación del patrón de macro-criminalidad debe buscar el adecuado esclarecimiento de la verdad sobre lo ocurrido en el marco del conflicto armado interno, así como determinar el grado de responsabilidad de los integrantes del grupo armado organizado al margen de la ley y de sus colaboradores. (Tribunal Superior de Bogotá, Sala de Justicia y Paz, 2014, Sentencia No. 110012252000201400027, p 181 - 182).

Las Directrices de la Unidad Nacional de Fiscalías para la Justicia y Paz no han sido numerosas, sin embargo, han sido claras, en el momento de ser utilizadas como estrategia para el proceso de priorización de casos, de conformidad con los criterios objetivo, subjetivo y complementario.

Hay que tener en cuenta que la estrategia de priorización, no ha sido aplicada en todos los Despachos o dentro de todas las investigaciones, como en los tres casos siguientes, que se detallan a continuación:

- En el caso de Wilson Salazar Carrascal, el cual fue fallado el día 19 de marzo de 2009 por parte del Tribunal de Bogotá - Sala de Justicia y paz, la condena fue proferido tras encontrarlo autor material de los "delitos homicidio agravado en concurso homogéneo y sucesivo, con extorsión y falsedad material en documentos públicos, delitos por los cuales fue acusado por la Fiscalía General de la Nación”.

A pesar de que en este caso, la actuación fue declarada nula por parte de la Sala de Casación Penal de la Corte Suprema de Justicia "a partir del acto de formulación de cargos...", los hechos objeto de la sentencia condenatoria no corresponden con aquellos que, por diferentes criterios, se ha considerado que merecen especial importancia o atención o priorización dentro de la investigación.

- En relación con la segunda condena proferida en el marco del Proceso de Justicia y Paz, dentro de la parte resolutoria, el Tribunal encontró a EDWARD COBOS TÉLLEZ, como coautor responsable de cometer los delitos de homicidio agravado, concierto para delinquir agravado, deportación, expulsión, traslado o desplazamiento forzado de población civil, 
secuestro simple, hurto calificado y agravado, utilización ilegal de uniformes e insignias y fabricación, tráfico y porte de armas y municiones de uso privativo de las fuerzas armadas, cometido concurso homogéneo y heterogéneo.

- De la misma forma, seña a UBER ENRIQUE BANQUEZ MARTINEZ, como coautor responsable de cometer los delitos de hurto agravado, deportación, expulsión, traslado o desplazamiento forzado de población civil, secuestro simple, hurto calificado y agravado, utilización ilegal de uniformes e insignias y fabricación, tráfico y porte de armas y municiones de uso privativo de las fuerzas armadas, cometido en concurso homogéneo y heterogéneo.

- En el caso de JORGE IVAN LAVERDE, alias "El Iguano", el Tribunal en la parte resolutiva de la sentencia, determinó lo siguiente:

Condenar a JORGE IVAN LAVERDE ZAPATA, identificado con Cédula de Ciudadanía número 71.985.935 de Turbo (Antioquia), a la pena principal de cuatrocientos ochenta (480) meses de prisión y multa de cuatro mil (4.000) salarios mínimos legales mensuales vigentes, luego de haber sido hallado responsable de cometer los delitos de homicidio en persona protegida, homicidio agravado, concierto para delinquir agravado, actos de terrorismo, tortura, secuestro simple, deportación, expulsión, traslado o desplazamiento forzado de población civil, destrucción y apropiación de bienes protegidos, exacción o contribuciones arbitrarias, daño en bien ajeno y fabricación, tráfico y porte de armas y municiones de uso privativo de las fuerzas armadas, cometidos en concurso homogéneo y heterogéneo. (Forer \& López, 2011, p.247).

Conductas descritas, que atentan contra el Derecho Internacional Humanitario, así como contra los Derechos Humanos, conforme a lo que fue expuesto en la parte motiva de la misma decisión.

En relación con el delito de concierto para delinquir agravado, que sin ser considerado uno de los más graves, si se considera que posee un nivel de importancia resaltado dentro de las 
directrices de la Unidad de Justicia y Paz de la Fiscalía General de la Nación, y al mismo tiempo, posee un carácter especial que hace posible su imputación y su posterior condena, debido a que la Corte Suprema de Justicia, en Sala de Casación Penal, lo ha considerado como delito base, dentro de todo el proceso de Justicia y Paz.

De los documentos provenientes de la Unidad de Justicia y Paz, sobre la estrategia de priorización de conductas punibles, de acuerdo con Forer y López Díaz (2011), se extraen tres premisas importantes, que son las siguientes:

- En primera medida el catalogo no es cerrado.

- En segunda medida, los listados no se refieren exclusivamente a tipo penales en la forma como los consagra el Código Penal Colombiano, sino que combinan aquellos con categorías de delitos y formas de comisión (en un sentido no estrictamente jurídico), como cuando alude a "masacres" o a "delitos de género" o a "atentados contra indígenas y menores", entre otros.

- En tercer lugar, se echa de menos un análisis sobre la región específica, y en ese sentido el Bloque o forma organizativa del grupo al margen de la ley, según el tipo de criminalidad que se presentó, pues no en todas las regiones se registraron las mismas formas de delincuencia y no todos los Bloques o grupos operaron de la misma forma o con los mismos patrones de comportamiento, aspecto que definitivamente, tiene que tomarse en cuenta. (Forer \& López, 2011, p.249 - 250).

De lo anterior, se analiza que las condenas proferidas dentro de la Unidad Nacional de Justicia y Paz de la Fiscalía General de la Nación, han sido proferidas por la comisión de 15 tipos de delitos, de los cuales, solamente cinco son parte de la "estrategia de priorización", y que son los siguientes: homicidios agravado, deportación, expulsión, traslado o desplazamiento forzado de la población civil, secuestro simple, destrucción y apropiación de bienes protegidos y homicidio en persona protegida.

Todo lo relacionado con el delito de concierto para delinquir agravado, el cual, en desarrollo de una forma de interpretación extensiva de la estrategia de priorización, podría llegar 
a ser considerada una sexta conducta punible, de todo el listado de conductas punibles que deberían ser priorizadas.

De lo anterior, se logra llegar a la conclusión de que en las sentencias que han sido proferidas dentro del Proceso de Justicia y Paz, la estrategia de priorización de conductas dentro del proceso de investigación no ha resultado ser eficaz, puesto que existen actualmente un número significativamente alto de delitos, que están siendo objeto de las condenas cuya importancia no corresponde con los criterios de priorización explicados anteriormente.

\subsection{Limitantes en las investigaciones, para los crímenes de lesa humanidad perpetrados en} Colombia

El primer análisis al que se puede llegar, de las decisiones de los jueces y de la Fiscalía General de la Nación, es la existencia de un enorme déficit en lo que respecta a la persecución penal de los delitos que atentan contra el Derecho Internacional Humanitario y de aquellos crímenes de alto impacto tanto a nivel nacional como a nivel internacional.

Al respecto se logra determinar, que si bien el déficit de persecución es cuantitativo, existen avances a nivel cualitativo que son muy significativos dentro del proceso de investigación y judicialización de estos crímenes.

Se puede determinar que desde el año 2004, fecha en la cual se produjo una importante decisión de la Unidad de Derechos Humanos de la Fiscalía General de la Nación, se ha producido un avance fundamental desde el punto de vista de la interpretación y aplicación de los nuevos tipos penales del Código Penal que forma parte del grupo de los crímenes que atentan contra el derecho internacional humanitario dentro del contexto del conflicto armado.

El nuevo Código Penal está vigente desde el año 2001, y por tal razón hasta este momento estamos asimilando su interpretación, por tal razón en el Sala Penal de la Corte Suprema de Justicia, no existen decisiones relacionadas con los nuevos delitos, ya que por la vía 
de la casación penal, dichos casos demoran muchos años para ser investigados y para llegar a fallo.

En relación con el punto anterior Aponte (2008), determina lo siguiente:

De acuerdo con la experiencia y el análisis de los casos que el autor ha hecho desde la elaboración del primer informe para el Grupo de Estudios Latinoamericanos sobre Derecho Penal Internacional, se ha podido comprobar que un caso en derechos humanos puede durar más de diez años hasta que sea decidido, cuando corresponda, en casación penal. (Ambos \& Malarino, 2008, p. 168).

Se debe tener en cuenta que por medio de autos, la Sala asume el estudio de los conflictos que se presentan por la competencia entre la jurisdicción penal militar y la jurisdicción civil ordinaria, es decir, que decide sobre ello, y entre diversos jueces de la justicia penal ordinaria. Por otra parte, además de decidir sobre la competencia, la Sala Penal introduce elementos de interpretación de las conductas que son importantes y relevantes dentro del análisis jurisprudencial.

Dentro de los diversos conflictos de competencia que se presentan, su estudio es muy importante, al momento de analizar el déficit de persecución penal para estas misma conductas, sobre todo lo que tiene que ver entre las conductas correspondientes a la justicia penal militar y la jurisdicción civil, debido a que la competencia es un fenómeno político, es decir, que la disputa está cruzada por diversos intereses políticos, es decir, que se entra a analizar quién juzga a quién y cómo, puesto que la misma, es una pregunta que en casos de derechos humanos y con repercusiones internacionales, genera grandes implicaciones de carácter político.

Aparte de dichos conflictos, también se presentan los conflictos entre los jueces de la justicia penal ordinaria.

Los crímenes de talla internacional y de alto impacto a nivel nacional, son asignados a jueces especializados, pero estas decisiones han sido caóticas, pues son de carácter político y 
están ligadas a luchas del Ejecutivo con diversos actores, es decir, con los narcotraficantes, guerrilleros o miembros de los grupos paramilitares y no han obedecidos a decisiones serias en las que prime la noción de competencia material.

Lo anterior se liga, en diversos casos que han sido fallados por la Sala Penal de la Corte, a problemas de competencia que se relacionan con la seguridad de los jueces, debido a que existen casos en los cuales, los jueces solicitan ser relevados del conocimiento de ciertos casos, pues en su territorio, y en su distrito, no cuentan con las garantías necesarias para llevar a cabo el proceso de investigación, judicialización y de gestión completos.

Esto se comprende, porque Colombia es un país que ha vivido situaciones de fragmentación territorial muy marcadas, y muchos de su territorios han sido fuente de disputa entre actores paraestatales y actores institucionales, dentro de los cuales, las instituciones han permanecido de manera simbólica, y han llegado a ser contingentes, ya que las decisiones fundamentales en dichos territorios las toman los violentos, los capos del narcotráfico, etc...

Por tal razón, se puede suponer que un Juez de la República, que debe decidir sobre crímenes de guerra y sobre delitos de lesa humanidad, dentro de un territorio ocupado por actores armados ilegales, es muy complicado que pueda llevar a cabo su gestión con coherencia y con independencia, pues se encontrará sometido a las amenazas, al terror y al miedo al que se encuentran sometidos dichos territorios.

Por otra parte, la Unidad de Derechos Humanos de la Fiscalía General de la Nación con sede en Bogotá, D.C., adelanta investigaciones sobre delitos de alto impacto que han sido perpetrados en las diferentes regiones de Colombia, en regiones en disputa y con gran cantidad de conflictos. En relación con dichos casos, una vez que se toman las decisiones, los expedientes se llevan a los juzgados regionales, los casos son fallados por los jueces de las mismas regiones y allí se establecen decisiones desiguales, que no solo tienen que ver solamente con el hecho central de la falta de condiciones de seguridad, sino con la desigual distribución de los recursos de formación y de competencias o de herramientas de capacitación de los mismos jueces que laboran en dichas regiones. 
La Sala Administrativa del Consejo Superior de la Judicatura y la Escuela Judicial de Colombia, han realizado grandes esfuerzos para capacitar a los jueces, por medio de la metodología formación de formadores, por la cual, se capacita de manera especial a algunos jueces y éstos la aplican dentro de las regiones en las cuales, están trabajando con el objetivo de llegar a todo el territorio nacional.

Pero es de entender que la formación es en todo caso desigual en países fragmentados y centralizados, de tal forma que los jueces de provincias no sólo alejadas, sino pobladas de diferentes conflictos, no cuentan con las mismas opciones de acceder a instrumentos de formación o a niveles de capacitación y ello se nota, aún más, cuando se trata de temas tan difíciles como los relacionados con el derecho penal internacional. (Ambos K, \& Malarino E, 2008)

Finalmente, son los mismos jueces en Bogotá, D.C., quienes buscan acceder a todas las políticas de formación, y reconocen dichas dificultades.

\title{
3.8. Realidad sobre el delito de desplazamiento forzado en Colombia
}

El delito de desplazamiento forzado, se encuentra consagrado dos veces en el en el Código Penal o Ley 599 de 2.000, la primera, en el Titulo II, capitulo único, que habla sobre los delitos contra personas y bienes protegidos por el derecho internacional humanitario, el cual, se cita a continuación:

Deportación, expulsión, traslado o desplazamiento forzado de población civil

\begin{abstract}
Art.159. El que, con ocasión y en desarrollo de conflicto armado y sin que medie justificación militar, deporte, expulse, traslade o desplace forzadamente de su sitio de asentamiento a la población civil, incurrirá en prisión de diez (10) a veinte (20) años, multa de mil (1.000) a dos mil (2.000) salarios mínimos legales mensuales vigentes, e inhabilitación para el ejercicio de derechos y funciones públicas de diez (10) a veinte (20) años. (Colombia, Código Penal y Procedimiento Penal, 2017, p.115 - 136)
\end{abstract}


Y la segunda, dentro del Título III, que habla de los delitos contra la libertad individual y otras garantías, en el capítulo quinto, de los delitos contra la autonomía personal, y el cual, se cita a continuación:

\section{Desplazamiento forzado}

Art. 180. El que de manera arbitraria, mediante violencia u otros actos coactivos dirigidos contra un sector de la población, ocasione que uno o varios de sus miembros cambie el lugar de su residencia, incurrirá en prisión de seis (6) a doce (12) años, multa de seiscientos (600) a mil quinientos (1.500) salarios mínimos legales mensuales vigentes y en interdicción de derechos y funciones públicas de seis (6) a doce (12) años.

No se entenderá por desplazamiento forzado, el movimiento de población que realice la fuerza pública cuando tenga por objeto la seguridad de la población, o en desarrollo de imperiosas razones militares, de acuerdo con el derecho internacional. (Colombia, Código Penal y Procedimiento Penal, 2017, p.115 - 136)

Acerca de la realidad de este delito en lo relacionado con sus víctimas, dentro del contexto del conflicto armado interno, en la Sentencia T - 971 de 2014, se determina lo siguiente:

Debe quedar claro que, debido a la gravedad y a la extrema urgencia a la que se ven sometidas las personas desplazadas, no se les puede someter al trámite de las acciones judiciales para cuestionar los actos administrativos de la Red, ni a la interposición de interminables solicitudes a la coordinadora del Sistema. Aquello constituye la imposición de cargas inaguantables, teniendo en cuenta las condiciones de los connacionales desplazados, y son factores que justifican la procedencia de la acción de tutela. En este contexto, se ha admitido que cuando quiera que en una situación de desplazamiento forzado una entidad omita ejercer sus deberes de protección para con todos aquellos que soporten tal condición, la tutela es un mecanismo idóneo para la protección de los derechos conculcados. (Colombia, Corte Constitucional, 2014, Sentencia T - 971). 
Por su parte, en la Sentencia T - 380 de 2016, de la Corte Constitucional en relación con este delito, determina lo siguiente:

Dada la inexistencia en el ordenamiento jurídico colombiano de un medio judicial expedito para la garantía de los derechos fundamentales de que los son titulares las personas víctimas de desplazamiento forzado, jurisprudencialmente se ha admitido que la acción de tutela constituye el mecanismo adecuado para su protección, ya que, en efecto, se trata de sujetos que gozan de un estatus constitucional de especial protección; por lo que resultaría desproporcionado imponerles la carga de agotar los recursos ordinarios para garantizar la procedencia del mecanismo constitucional, pues de no ser así se estaría yendo en contravía del reconocimiento de la marginalidad que se hace extensiva en el tiempo, como ya se explicó, y se estaría validando una actitud revictimizante en contra de esta población. (Colombia, Corte Constitucional, 2016, Sentencia T - 380).

En la Sentencia T - 025 de 2004 de la Sala Tercera de Revisión de la Corte Constitucional, se enfatiza, en relación con el tema de la asignación de recursos para la protección de los derechos fundamentales de los desplazados, lo siguiente:

El que las leyes anuales del presupuesto limiten la asignación de recursos dirigidos a la ayuda de la población desplazada, es un indicativo de la realidad fiscal y macroeconómica en la que se encuentra el país. Sin embargo, ello no significa que las leyes de presupuesto constituyan una modificación de los alcances de la Ley 387 de 1997. Desde el punto de vista constitucional, es imperioso destinar el presupuesto necesario para que los derechos fundamentales de los desplazados tengan plena realización. La obligación constitucional del Estado de garantizar una protección adecuada a quienes por razón del desplazamiento forzado interno se encuentran en condiciones indignas de vida no puede ser aplazada indefinidamente. La Ley 387 de 1997 reconoció que la atención de la población desplazada es urgente y prioritaria. La jurisprudencia de esta Corporación ha reiterado la prelación que tiene la asignación de recursos para atender a esta población y solucionar así la crisis social y humanitaria que representa este fenómeno. No obstante, ello no ha sucedido y de esta forma se ha desconocido la Carta Política, lo ordenado por el Congreso de la República y 
lo dispuesto en las políticas de desarrollo adoptadas por el propio Ejecutivo. (Colombia, Corte Constitucional, 2004, Sentencia T-025, p.3).

Por su parte, la Corte Interamericana de Derechos Humanos en el Caso de la masacre de Mapiripán vs. Colombia en relación con la realidad sobre el delito de desplazamiento forzado por la violencia, se determina de la siguiente manera:

171. La Corte considera de relevancia para definir el contenido y alcance del artículo 22 en un contexto de desplazamiento interno, el contenido de los Principios Rectores de los Desplazamientos Internos emitidos en 1998 por el Representante del Secretario General de las Naciones Unidas.

172. Además, también resultan útiles las regulaciones sobre desplazamiento contenidas en el Protocolo II a los Convenios de Ginebra de 1949.

173. Los hechos del presente caso se enmarcan en una situación generalizada de desplazamiento forzado interno que afecta a Colombia y que es causada por el conflicto armado interno.

177. En razón de la complejidad del fenómeno del desplazamiento y de la amplia gama de derechos que afecta y en atención a dichas circunstancias de debilidad, vulnerabilidad e indefensión en que se encuentran los desplazados, su situación puede ser entendida como una condición individual de facto de desprotección. Esta condición tiene una dimensión social, que se presenta en el contexto histórico específico del conflicto armado interno en Colombia, y conduce al establecimiento de diferencias en el acceso de los desplazados a los recursos públicos administrados por el Estado.

178. En relación con esa situación de desigualdad, es pertinente recordar que existe un vínculo indisoluble entre las obligaciones erga omnes de respetar y garantizar los derechos humanos y el principio de igualdad y no discriminación (...) En cumplimiento de dichas obligaciones, los Estados deben abstenerse de crear situaciones de discriminación de jure o de facto, y adoptar medidas positivas.

186. (...) [L]a Corte observa que la situación de desplazamiento forzado interno que han enfrentado los familiares no puede ser desvinculada de las otras violaciones. Las circunstancias del presente caso y la especial situación de vulnerabilidad que afecta a 
dichas personas, incluyen pero trascienden el contenido de la protección debida por los Estados en el marco del artículo 22. En efecto, el desplazamiento de esos familiares tiene origen en la desprotección sufrida durante la masacre y revela sus efectos en las violaciones a su integridad personal y en las consecuencias de las faltas al deber de investigar los hechos, que han derivado en impunidad parcial. Además, fue analizada la violación del artículo 19 de dicho instrumento por la desprotección a que se han visto sometidos niños y niñas al momento de ser desplazados. El conjunto de estos elementos llevan al Tribunal a considerar que, más allá del contenido normativo del artículo 22, la situación de desplazamiento analizada ha afectado el derecho de los familiares de las víctimas a una vida digna, en relación con el incumplimiento de las obligaciones de respeto y garantía de los derechos consagrados en esas normas.

188. Mediante una interpretación evolutiva del artículo 22 de la Convención, tomando en cuenta las normas de interpretación aplicables y de conformidad con el artículo 29.b de la Convención - que prohíbe una interpretación restrictiva de los derechos - esta Corte considera que el artículo 22.1 de la Convención protege el derecho a no ser desplazado forzadamente dentro de un Estado Parte en la misma. Para efectos del presente caso, esto también ha sido reconocido por dicha Corte Constitucional de Colombia al interpretar el contenido del derecho constitucional a escoger su lugar de domicilio, "en la medida en que para huir del riesgo que pesa sobre su vida e integridad personal, los desplazados se ven forzados a escapar de su sitio habitual de residencia y trabajo".

189.Por las razones anteriores, la Corte declara que Colombia violó el artículo 22.1 de la Convención Americana, en relación con los artículos 4.1, 5.1, 19 y 1.1 de dicho tratado (...). (San José de Costa Rica, Corte Interamericana de Derechos Humanos 2005, Caso de la Masacre de Mapiripán vs. Colombia”, p.6).

Esta conducta típica, como bien sabemos constituye un crimen a nivel nacional como internacional, pero el déficit de persecución es totalmente absoluto. En Colombia, existe un número más o menos tres millones de desplazados, pero no existe certeza en dichas cifras, pero lo que no se comprende es la razón por la cual, no existe un número considerable de casos penales sobre ellos. 
En todas las capitales de departamento, existen desplazados por la violencia, se han tomado alguna medidas de protección, se ha discutido durante años la mejor forma de enfrentar dicha problemática, han existido tomas de lugares públicos por parte de los mismos desplazados para demandar soluciones a sus problemas, la Corte Constitucional ha emitido innumerables sentencias de tutela para lograr en cierta medida la protección y tutela de sus derechos fundamentales, pero lamentablemente aún no existen casos penales por medio de los cuales, se sancione verdaderamente a los responsables de las conductas propias de los desplazamientos forzados en nuestro país.

Una explicación para todo esto puede ser, siendo el desplazamiento forzado un tipo penal pluriofensivo, pues algunas de sus conductas son investigadas desde el ámbito de las lesiones personales, como acciones en contra de la libertad, contra la vida pero en sí mismo, este delito se va perdiendo dentro de su proceso de tipificación. Además, el delito de desplazamiento forzado, sería el resultado final de múltiples acciones cometidas contra un grupo específico de personas dentro de poblaciones con innumerables conflictos.

Es decir, sobre personas, en las cuales se cometen desapariciones, se les amenaza, se las atemoriza, se las lesiona o se las secuestra, y como resultado final, debido a dichas acciones se produce un desplazamiento, pero dicho resultado, no llega al sistema penal, pues en la gran mayoría de los casos, solamente se investigan las conductas que anteceden al desplazamiento como tal.

Esto significa, que a pesar de que los desplazados sean miles, a nivel social, ellos son invisibles y también lo son para el sistema penal, por otra parte, también lo son, porque ni siquiera logran ingresar a los programas de gobierno en su propio beneficio, pues desean no ser detectados o ubicados por quienes los han desplazado, es decir, que siguen siendo víctimas permanentes.

Al respecto, en la jurisprudencia nacional la Sentencia T - 025 de 2004, de la Sala Tercera de Revisión de la Corte Constitucional, se ha determinado lo siguiente, en relación con el delito de desplazamiento forzado: 
El patrón de violación de los derechos de la población desplazada ha persistido en el tiempo, sin que las autoridades competentes hayan adoptado los correctivos suficientes para superar esas violaciones, y sin que las soluciones puntuales ordenadas por la Corte frente a las violaciones detectadas en las sentencias dictadas hasta el momento, hayan contribuido a impedir la reincidencia de las autoridades demandadas en tutela. Inclusive, se ha llegado a agravar la situación de afectación de los derechos de la población desplazada ante la exigencia impuesta por algunos funcionarios de la interposición de acciones de tutela como requisito previo para que las autoridades encargadas de su atención cumplan con sus deberes de protección. (Colombia, Corte Constitucional, 22 de enero, Sentencia T - 025, p.2).

Se debe tener en cuenta que cuando el sistema penal aborda los casos de desplazamiento, lo hace de tal forma, que se debe agregar mayor conocimiento a dicho delito complejo, por ejemplo, en una decisión de la Unidad de Derechos Humanos de la Fiscalía, radicada en el proceso No. 1941 del 3 de junio de 2005, el despacho calificó el mérito del sumario respecto de dos procesados por varios delitos, entre ellos el desplazamiento forzado.

En el desplazamiento forzado, las personas huyen por causa de la guerra, de la acción de los actores armados en contra de la población civil o por causa de enfrentamientos o de combates, y en éste último evento luego de que contra ellas se cometan toda clase de conductas criminales y atroces.

Después de efectuar un proceso probatorio complejo, con base en los testimonios de las víctimas que dan cuenta de una crueldad sin límites, de alguna forma se ha podido por parte de la Fiscalía identificar e individualizar a los sospechosos, y dentro del levantamiento de los testimonios se puede observar, de que antes de producirse un desplazamiento forzado, durante meses anteriores, se han sumado una serie de amenazas, acciones criminales individuales, búsquedas selectivas de futuras víctimas sobre las cuales existen sospechas de ser informantes, o que de las cuales se puede colegir que pertenecen a grupos armados enemigos. 
El drama real que se vive en algunos territorios del país, se logra demostrar, en el simple hecho, de que las autoridades civiles son remplazadas por actores armados, los cuales las amenazan, para que no se logren adelantar las investigaciones por los hechos perpetrados en la zona de conflicto armado interno, y de esta forma, no se logre superar el estado de cosas inconstitucional existente en nuestro Estado Colombiano en relación con la población desplazada, de conformidad con lo establecido en la Sentencia T - 025 de 2005, de la Sala Tercera de Revisión de la Corte Constitucional, la cual, determina lo siguiente:

Varios elementos confirman la existencia de un estado de cosas inconstitucional respecto de la situación de la población internamente desplazada. En primer lugar, la gravedad de la situación de vulneración de derechos que enfrenta la población desplazada fue expresamente reconocida por el mismo legislador al definir la condición de desplazado, y resaltar la violación masiva de múltiples derechos. En segundo lugar, otro elemento que confirma la existencia de un estado de cosas inconstitucional en materia de desplazamiento forzado, es el elevado volumen de acciones de tutela presentadas por los desplazados para obtener las distintas ayudas y el incremento de las mismas. En tercer lugar, los procesos acumulados en la presente acción de tutela, confirman ese estado de cosas inconstitucional y señalan que la vulneración de los derechos afecta a buena parte de la población desplazada, en múltiples lugares del territorio nacional y que las autoridades han omitido adoptar los correctivos requeridos. En cuarto lugar, la continuación de la vulneración de tales derechos no es imputable a una única entidad. En quinto lugar, la vulneración de los derechos de los desplazados reposa en factores estructurales enunciados en el apartado 6 de esta providencia dentro de los cuales se destaca la falta de correspondencia entre lo que dicen las normas y los medios para cumplirlas, aspecto que adquiere una especial dimensión cuando se mira la insuficiencia de recursos dada la evolución del problema de desplazamiento y se aprecia la magnitud del problema frente a la capacidad institucional para responder oportuna y eficazmente a él. En conclusión, la Corte declarará formalmente la existencia de un estado de cosas inconstitucional relativo a las condiciones de vida de la población internamente desplazada. Por ello, tanto las autoridades nacionales como las territoriales, dentro de la órbita de sus competencias, habrán de adoptar los correctivos que 
permitan superar tal estado de cosas. (Colombia, Corte Constitucional, 2004, Sentencia T 025, p.5).

Finalmente, la Corte Interamericana de Derechos Humanos, en la Sentencia de la masacre de Ituango vs. Colombia, en lo que respecta a la realidad acerca del delito de desplazamiento forzado, determina lo siguiente:

25.104 El problema del desplazamiento forzado interno en Colombia, cuya dinámica actual tuvo su inicio en la década de los años ochenta, afecta a grandes masas poblacionales y se va agravando progresivamente. Según fuentes gubernamentales, de 1995 a 2002 se registraron 985.212 personas desplazadas. Según el Alto Comisionado de Naciones Unidas para los Derechos Humanos, si bien se ha observado una reducción en el número de nuevos casos de desplazamiento, en 2004 el número total de desplazados aumentó en relación con años anteriores. La Red de Solidaridad Social tiene registrados alrededor de 1.5 millones de personas desplazadas 153, mientras que otras fuentes gubernamentales hablan de entre 2.5 y 3 millones de desplazados.

125.105 Se ha determinado que la crisis humanitaria provocada por el fenómeno del desplazamiento interno es de tal magnitud que implica una violación "masiva, prolongada y sistemática" de diversos derechos fundamentales de este grupo.

125.106 Los motivos y las manifestaciones de la vulnerabilidad acentuada en los desplazados han sido caracterizadas desde diversas perspectivas. Dicha vulnerabilidad es reforzada por su proveniencia rural y se han determinado graves repercusiones psicológicas en las personas afectadas. Este problema afecta con especial fuerza a las mujeres, quienes principalmente son cabezas de hogar y representan más de la mitad de la población desplazada. En general, las mujeres, los niños y los jóvenes son los grupos más afectados por el desplazamiento. La crisis del desplazamiento interno provoca, a su vez, una crisis de seguridad, dado que los grupos de desplazados internos se convierten en un nuevo foco o recurso de reclutamiento para los propios grupos paramilitares, de narcotráfico y de la guerrilla. El retorno de los desplazados a sus hogares carece, en muchos casos, de las condiciones necesarias de seguridad y de dignidad para ellos156. (San José de Costa Rica, 
Corte Interamericana de Derechos Humanos, 2006, Caso de las Masacres de Ituango Vs. Colombia, p.659.

\subsubsection{La falta de una adecuación típica adecuada para el delito de desplazamiento forzado en Colombia}

Dentro del proceso de investigación del delito de desplazamiento forzado, se puede determinar que la Fiscalía al citar a diversas autoridades municipales, ha establecido lo siguiente:

Sobre las posibles causas de estas muertes, nosotros nos trasladamos a la semana de ocurridos los hechos a las zonas, y encontramos un abandono total de dos viviendas, porque se inició el desplazamiento que llegaron a Maracaibo, Uribia, Maicao, y no conseguimos ninguna persona en la zona. ...Las personas que encontramos aquí no querían hablar, estaban muy temerosas, existía pánico, miedo, no se explicaban qué había pasado. Para ellos fue una pesadilla. (Ambos \& Malarino, 2008, p.177)

Los delitos base en relación con el desplazamiento forzado, es decir, las conductas previas, generan el carácter pluriofensivo de éste delito, y al respecto la Fiscalía en sus consideraciones en relación con el concurso de delitos y de la autoría, determina lo siguiente:

Es coautor aquel autor que tiene el dominio de la realización del hecho conjuntamente con otros autores, con los cuales hay un plan común y una distribución de funciones en desarrollo del mutuo acuerdo. No es una suma de autorías individuales, sino una forma de responsabilidad por la totalidad del hecho, y por lo tanto, todos deben responder como autores. (Ambos \& Malarino, 2008, p.177)

Es importante aclarar, que el concurso material heterogéneo tiene lugar en el escrito de resolución de acusación de la Fiscalía, de ésta manera, se imputan los delitos de concierto para delinquir y de terrorismo, y es necesario tener en cuenta, que en todos los casos de acciones diversas contra numerosas personas en escenarios de violaciones masivas de derechos humanos, al lado de los delitos comunes, y de violaciones al Derecho Internacional humanitario, se debe 
imputar el delito de concierto para delinquir, y también el delito de terrorismo, por el hecho de ganarse zozobra entre los pobladores dentro de la zona de conflicto, esto significa, que tanto el terrorismo como el concierto para delinquir obran como ámbito general de imputación de las demás conductas delictivas perpetradas.

\subsection{Inexistencia de elementos contextuales en los tipos penales colombianos}

La investigación de una situación corresponde a la existencia de un "elemento contextual" del tipo penal internacional, que no existe para los tipos penales dentro del derecho interno colombiano, donde no existe una tipificación exacta para dichos delitos.

Sobre lo anterior, se puede entrar a analizar las sentencias de la Sala de Casación Penal de la Corte Suprema de Justicia, en particular sobre los casos de la "para política", que son resultado de las audiencias de Justicia y Paz, allí se verifica, que la Sala Penal, al inclinarse por aceptar imputaciones desde el marco de la autoría mediata por el dominio de aparatos organizado de poder, sustenta sus condenas en varias series de elementos contextuales, que difieren de la práctica habitual de la sala y que en materia probatoria le reconocen un valor agregado al contexto, donde lo convierten en medio de prueba.

En relación con la implementación del Estatuto de Roma en Colombia, Alejandro Aponte Cardona, 2008, determina lo siguiente:

que los delitos que se reseñan a continuación hacen parte de acciones individuales y, por esta razón, en ellos no se configura el denominado elemento contextual. Es decir, no están condicionados al hecho de que se cometan como parte de un ataque generalizado o sistemático contra una población civil y con conocimiento de dicho ataque tal como lo establece el art. $7^{\circ}$., del Estatuto de Roma.

Lo anterior significa, que en el derecho penal internacional se requiere de la determinación de elementos contextuales, mal podría entenderse que los mimos se analicen a la luz de la creación de contextos, debido a que los elementos contextuales de los crímenes 
internacionales se demuestran mediante pruebas judiciales y se debaten de la misma forma y bajo las mismas reglas de cualquier otro medio de prueba, y el estudio no contribuye a lograr la memoria histórica, sino que tiene el poder de convencimiento necesario, y por lo tanto, debe ser evaluado a la luz del derecho.

Los elementos contextuales de los crímenes internacionales tales como la política, la generalidad, la sistematicidad entre otros, se deben entrar a probar, puesto que el tipo penal internacional lo exige de esa manera y además porque la característica principal de los crímenes es que poseen una gravedad tal que los convierte en una ofensa contra la humanidad.

En Colombia no es posible adelantar la investigación de delitos haciendo uso de los elementos contextuales, debido a que los tipos penales internos no poseen dichos elementos, a diferencia de los tipos penales existentes en el derecho penal internacional, y por lo tanto, no es relevante hacer una imputación en base a ellos. El valor que puede tener la demostración de estos elementos contextuales, logra demostrar el derecho a la verdad, y en este caso, se analiza si las sentencias judiciales son el mejor estadio para satisfacer este derecho o si la cuestión del contexto y de la memoria histórica, debería ser tema de una comisión de la verdad con las competencias que exige el derecho internacional.

Se debe tener en cuenta, que la investigación en contexto, orienta las líneas de investigación que debe seguir la Fiscalía, y es un criterio para valorar e interpretar las pruebas que se hayan obtenido dentro de la investigación, lo anterior, teniendo en cuenta de que los contextos no pueden ser usados como una prueba directa, ya que dentro de ellos no hay elementos que incidan en la responsabilidad penal de los individuos, además, los elementos contextuales de los crímenes internacionales, no se logran probar mediante contextos, sino mediante pruebas directas, practicadas con rigurosidad y debatidas en juicio. 


\subsection{Los crímenes de lesa humanidad y las infracciones al Derecho Internacional Humanitario}

Una vez que el Fiscal dentro de un caso sobre crímenes de alto impacto, encuentra probado un elemento fundamental para establecer que se trata de violaciones al Derecho Internacional Humanitario, que son de ocurrencia permanente y persistente de delitos cometidos sobre un territorio y la conexión que existe dentro de las conductas, dicho análisis le sirve para hacerle frente a una situación como es, la mezcla de toda clase de delitos, unos como violaciones a los derechos humanos, al derecho intencional de los derechos humanos, y al Derecho Internacional Humanitario, y otros como delitos comunes.

La siguiente pregunta que se podría hacer el fiscal del caso, es si en el ámbito general de un conflicto armado interno, en el cual, se producen infracciones al Derecho Internacional Humanitario, se producen simultáneamente delitos de lesa humanidad, y la conclusión a la cual, llegaría dicho fiscal sería que sí, de conformidad con el siguiente argumento:

De esta forma, se enmarca el fallo dentro normatividad en materia de derecho internacional humanitario y bajo este marco, se interpretarán las normas de derechos humanos sobre delitos de lesa humanidad, como es el de desaparición forzada, que pese a tener fundamentos totalmente diferentes, puede cometerse dentro de un conflicto armado interno. (Aponte Cardona, 2008, p.209).

De esta manera, la Fiscalía dentro de un contexto de conflicto armado interno y del Derecho Internacional Humanitario, puede incorporar en un concurso de conductas relacionadas con el Derecho Internacional Humanitario, con delitos de lesa humanidad y con delitos comunes. No existe un Código Penal especial para los crímenes internacionales, pero en el ejercicio argumentativo se pone orden sobre el carácter de dichas conductas, esto es, realizando una observación con matices de todas las conductas cometidas.

Por otra parte, y en cuanto a la autoría de dichos crímenes, la Fiscalía señala a los responsables como coautores de los delitos, y encuentra que no se trata de establecer 
previamente todos los actos que se van a ejecutar, sino que dentro de todo un plan inicial muy determinado, surgen diversas conductas, que atentan contra los bienes jurídicos, a medida que así lo requieran los fines del grupo.

De esta manera, no se podrá analizar que no había intención de los miembros distintos del comandante del grupo a cometer ilícitos, porque desde un principio el riesgo creado por todos fue cuantitativamente suficiente para afectarlos.

De lo anterior, se logra concluir lo siguiente, en relación con la coautoría de empresas criminales conjuntas y aparatos organizados de poder:

La actividad delincuencial de una organización criminal jerárquicamente organizada cobija a cada uno de los miembros, ya que cada uno de los miembros, tiene un dominio funcional frente a los mismos pero también una relación de pertenencia sobre ellos. (Aponte Cardona, 2008, p.211). 


\section{Capítulo 4}

\section{Estudio de caso y entrevistas}

\subsection{Análisis criminal previo del caso, por medio de la metodología de investigación penal de análisis de contexto}

El término contexto, para el estudio del caso materia de análisis, se define de la siguiente manera:

Estudio sistemático e interdisciplinario del delito y de los factores problemáticos que alteran la convivencia social e interesan a la investigación penal (sociodemográficos, espaciales y temporales, entre otros), para apoyar la función constitucional asignada a la Fiscalía General de la Nación y propender por la garantía de los derechos fundamentales de las víctimas a la verdad, la justicia, la reparación y la no repetición. (Colombia, Fiscalía General de la Nación, 2012, Directiva 0001, p.107).

\subsubsection{Contexto de la situación fáctica}

Tal y como se ha determinado en el presente trabajo, la estrategia de la investigación en contexto, en el caso objeto de estudio, cumple las siguientes finalidades:

- Es pauta de análisis y herramienta para la Fiscalía al servicio de su función constitucional de investigar y determinar las circunstancias de tiempo, modo y lugar en que ocurrieron los hechos criminales, así como para identificar los patrones y los planes criminales.

- A falta de distinción expresa, se aplica tanto para la investigación penal de los delitos priorizados en Justicia Transicional como en Justicia Ordinaria, y responder a la categoría de crímenes de sistema o macro crímenes. (Barbosa \& Bernal, 2015, p.145).

Los hechos, objeto del escrito de acusación de la Subdirección Seccional de Fiscalías del Valle del Cauca, ocurrieron en la zona urbana del Distrito Especial de Buenaventura, Valle del Cauca durante los años 2012, 2013 y 2014. 
De conformidad con los elementos materiales probatorios, evidencia física e información legalmente obtenida, se determina que los acusados en el caso sub judice, pertenecieron a las organizaciones criminales La Empresa y Urabeños (posteriormente autodenominados Gaitanistas), participando dentro de sus planes criminales, estableciendo una política de violencia, dirigida contra la población civil, la cual, tenía como propósito principal, mantener el control criminal en los barrios y comunas del Distrito Especial de Buenaventura, y dicha política de violencia, fue la causante del cambio de residencia obligatorio de más de 9000 familias durante los años 2012, 2013 y 2014.

- Situación fáctica representativita de los patrones de conducta delictiva característica de determinada organización criminal. A partir de la priorización del caso ilustrativo se deberá (i) construir el respectivo contexto;(ii) acumular las actuaciones a cargo de la Fiscalía General de la Nación que evidencien la existencia de la organización criminal y la ejecución de las conductas ilícitas que le puedan ser atribuidas a sus presuntos miembros, se trate o no de la misma clase de delito; y (iii) emplear los esquemas de imputación penal que resulten legalmente idóneos para investigar, y acusar a los presuntos máximos responsables, colaboradores y financiadores. Su resolución debe tener un amplio efecto reparador. (Barbosa \& Bernal, 2015, p.107).

\subsubsection{Criterios de priorización aplicables al caso}

Artículo 16 A. ADICIONADO. Art. 13, Ley 1592 de 2012.Criterios de priorización de casos. Con el fin de garantizar los derechos de las víctimas, el Fiscal General de la Nación determinará los criterios de priorización para el ejercicio de la acción penal que tendrán carácter vinculante y serán de público conocimiento.

Los criterios de priorización estarán dirigidos a esclarecer el patrón de macrocriminalidad en el accionar de los grupos armados organizados al margen de la ley y a develar los contextos, las causas y los motivos del mismo, concentrando los esfuerzos de investigación en los máximos responsables. Para estos efectos, la Fiscalía General de la Nación adoptará mediante resolución 
el "Plan Integral de Investigación Priorizada" (Colombia, Congreso Nacional de la Republica, 2005, Ley 975, p.28).

Criterio de priorización: Parámetro lógico que sirve para focalizar la acción investigativa de la Fiscalía General de la Nación hacia determinadas situaciones y casos, con el fin de asegurar un mayor impacto y un mejor aprovechamiento de los recursos administrativos y logísticos. (Barbosa \& Bernal, 205, p.108).

Fines de la priorización: La política de Priorización, busca alcanzar los siguientes fines:

- Seguridad ciudadana. La posibilidad de asociar casos, a partir de la identificación de elementos comunes, permite combatir de manera más efectiva la criminalidad organizada.

- Conocimiento del contexto de conflicto armado. La construcción de los escenarios delictivos en todas sus dimensiones es necesario para abordar procesos de justicia transicional.

- Legitimidad y eficacia en la administración de justicia. La racionalización de los recursos de la Fiscalía General de la Nación permite que se administre justicia con eficacia y trasparencia hacia la ciudadanía, lo que a su vez posibilita reducir la impunidad.

- Atender las exigencias de la sociedad civil. Los representantes de los distintos sectores de la sociedad han planteado la necesidad de estudiar la criminalidad en su contexto, para así desarticular de manera más efectiva a los grupos que vulneran gravemente los derechos humanos y que atentan contra sus defensores y defensoras.

Máximo responsable: El concepto de máximo responsable se aplica respecto a dos categorías diferentes, a saber:(i) aquel que dentro de la estructura de mando y control de la organización delictiva sabía o podía prever razonablemente la perpetración de crímenes en desarrollo de la ejecución de los planes operativos; y (ii) de manera excepcional, se trata de aquellas personas que han cometido delitos particularmente notorios, con independencia de la posición que ocupaban en la organización delictiva . (Barbosa \& Bernal, 205, p.109). 
Patrones criminales: Conjunto de actividades, medios logísticos, de comunicación y modus operandi delictivo, desarrollados en un área y periodo de tiempo determinados, de los cuales se pueden extraer conclusiones respecto a los diversos niveles de mando y control de la organización criminal. Su determinación ayuda a establecer el grado de responsabilidad penal de sus integrantes y hace parte fundamental de la construcción del contexto. (Barbosa \& Bernal, 205, p.109).

- Test de priorización: Juicio que permite realizar una ponderación entre los diversos criterios de priorización a efectos de recomendar o decidir sobre una situación o caso, y la metodología será la siguiente:

- Adelantar un análisis criminal previo.

- Examinar el caso o la situación bajo estudio con la totalidad de los criterios de priorización.

Adoptar la respectiva recomendación o decisión, según sea el caso, debiendo cumplir para ello con una fuerte carga argumentativa. (Barbosa \& Bernal, 205, p.110).

\subsubsection{Criterio Objetivo}

El criterio objetivo se refiere a la gravedad de los efectos generados con las conductas criminales y a la importancia de adelantar su investigación y judicialización. (Montealegre Lynett, Perdomo, La Rota Uprimmy, Natiello, Zambrano \& Puerto, 2015, p.11).

Las conductas delictivas ejecutadas por dichas organizaciones criminales, en dicha zona de conflicto, se resumen en las siguientes:

Presencia armada en los diferentes barrios y comunas de Buenaventura: El objetivo de dicha presencia armada en los diferentes barrios de Buenaventura, era el de impedir el ingreso de la otra organización criminal, para mostrar poderío y generar temor y miedo en la población y mantenerla bajo su control, y para lograrlo, utilizaban armas de corto alcance como pistolas, revólveres, escopetas y de largo alcance, como fusiles e incluso granadas de fragmentación. 
Control territorial $\boldsymbol{y}$ poblacional: Las organizaciones criminales mencionadas, establecían controles en los barrios bajo su dominio, por medio de las barreras invisibles, delimitando los puntos por los que sólo habitantes del barrio y/o personas conocidas por la organización podía transitar. Por otra parte, se establecieron reglas de convivencia, prohibiendo las riñas entre vecinos y se establecieron requisas para familiares y amigos que venían de visita al barrio, se prohibieron las relaciones con los organismos policiales y militares y se advertía sobre las consecuencias de delatar a la organización ante las autoridades, se establecieron tarifas de multas o sanciones por no cumplir las reglas de la organización y se controlaba la construcción de nuevas viviendas o su remodelación, imponiendo tarifas de cobro (extorsión) frente a esta actividad.

Enfrentamientos: La confrontación entre las organizaciones criminales mencionadas, generaba como consecuencia, enfrentamientos armados, los cuales se identificaban como balaceras, los cuales, producían temor y zozobra en la misma población, al producirse disparos indiscriminados, lo que generaba peligro para la comunidad.

Homicidios: de las confrontaciones armadas dentro de los barrios y las comunas de Buenaventura, se concluye que se produjeron cantidad de homicidios, de personas involucradas en el conflicto, como de personas ajenas a dicha confrontación, que no cumplían con las exigencias de las organizaciones, que sobrepasaban la barreras territoriales establecidas o que eran pasaban información a la organización enemiga o a la autoridad.

Homicidio bajo la modalidad de desmembramiento: Era una de las modalidades de homicidio utilizadas por estas organizaciones, con el objetivo se sembrar el terror tanto en sus enemigos como en toda la población, al desmembrar a las personas, y luego arrojando las partes corporales como cabeza, tronco, piernas y brazos en distintos sectores de la ciudad. De acuerdo a los registros oficiales obtenidos por parte de la Fiscalía, durante los años 2012, 2013 y 2014 se presentaron alrededor de 38 casos de cuerpos desmembrados, cuyas partes corporales fueron encontradas en distintos sectores de la ciudad y en el mar. 
Extorsión: Por medio de exigencias económicas que estas organizaciones criminales, les hacían a los comerciantes, moto - taxistas, pescadores, trasportadores y en sí a cualquier persona, que pertenezca a un gremio que generara ingresos económicos, para que colaboraran con la causa, exigencias económicas que denominaron impuesto y que se fueron extendiendo a los habitantes de la zona, llegando a realizar cobros en cada casa de la zona.

Constreñimiento para delinquir y reclutamiento de menores: La confrontación armada de dichas organizaciones, generaron necesidades de personal, al punto que se trataba de convencer a los jóvenes y menores de las localidades de Buenaventura, para que ingresaran a las filas de las organizaciones, mediante amenazas o coacción.

Amenazas: Se presentaban de forma recurrente, para que no suministraran información a las autoridades, no tuvieran relación con el bando enemigo o para que se comportaran de cierto modo frente a la organización.

Desaparición forzada: Una de las prácticas más constantes de estas organizaciones, ya que algunos testigos ilustran sobre fosas en las que se enterraban los cadáveres de personas asesinadas por la organización, algunos habían sido desmembrados, además, ilustran sobre el depósito de cadáveres en el mar, algunos de ellos aún no han sido hallados.

Secuestro: Las organizaciones registran, prácticas de secuestro extorsivo, en donde retenían a las personas por un corto periodo de tiempo, para hacer exigencias económicas concretas.

Rumores, grafitis y panfletos: Era una situación, provocada por las organizaciones, sobre el poderío armado, panfletos amenazantes y grafitis.

Afectación cultural: dentro de la zona, se prohibieron algunos rituales y ceremonias religiosas y costumbres de la población afro - descendiente, por conveniencia de las organizaciones criminales presentes en la zona de conflicto. 
Los acusados, debidamente individualizados dentro del escrito de acusación, por medio de los roles que cada uno de desempeñaba dentro de las organizaciones criminales, contribuyeron a la construcción y mantenimiento del panorama de violencia en dicha zona, que generó como consecuencia, que la población civil cambiara su lugar de residencia, con el fin de salvaguardar su vida y su integridad personal, siendo vulnerada la libertad individual de dicha población, debido a que no se trasladaban de un barrio a otro dentro de la zona de Buenaventura, por su propio deseo o para buscar mejores oportunidades, únicamente lo hacían, a causa de la presión y de la violencia generada por los acusados.

De acuerdo a los registros de la Unidad para la Atención y Reparación Integral a las Víctimas (UARIV), durante los años 2012, 2013 y 2014, fueron incluidas en el registro Único de Víctimas, como víctimas de Desplazamiento Forzado provocado por la violencia generada por las organizaciones criminales La Empresa y Los Urabeños (Gaitanistas), 9052 declaraciones, que corresponden a núcleos familiares de desplazados, las cuales, se encuentran plenamente identificadas dentro del escrito de acusación.

La Fiscalía General de la Nación, cuenta con 230 denuncias de personas que indican haber cambiado su lugar de residencia por la violencia generada por estas organizaciones criminales y por sus miembros, existen, más de 200 constancias expedidas por los presidentes de la Juntas de Acción Comunal de los diferentes barrios de Buenaventura, que dan cuenta del éxodo de la población producto de la guerra entre estas organizaciones criminales La Empresa y Urabeños.

\subsubsection{Criterio Subjetivo}

El criterio subjetivo se refiere a la caracterización de las personas o grupos que realizan o se ven afectados por un fenómeno criminal, apuntando especialmente a la persecución de criminalidad organizada y a la judicialización de aquellos delitos que responden a patrones históricos, culturales y/ o sociales de discriminación. (Montealegre, Perdomo, La Rota Uprimmy, Natiello, Zambrano \& Puerto, 2015, p.8 - 11). 
La Fiscalía General de la Nación, cuenta con 230 denuncias de personas que indican haber cambiado su lugar de residencia por la violencia generada por estas organizaciones criminales y por sus miembros, existen, más de 200 constancias expedidas por los presidentes de la Juntas de Acción Comunal de los diferentes barrios de Buenaventura, que dan cuenta del éxodo de la población producto de la guerra entre estas organizaciones criminales La Empresa y Urabeños.

Por otra parte, en el mismo escrito de acusación, se determinó la presencia en los barrios y comunas de Buenaventura de la organización criminal La Empresa a través de hombres armados, quienes desarrollaban, toda clase de conductas delincuenciales con el objetivo de someter a la población.

Desde el año 2009, esta organización ocupó los espacios dejados por las Autodefensas Unidas de Colombia luego del proceso de desmovilización, consolidándose como la organización criminal dominante en el territorio, pues poseía el control de las actividades criminales de narcotráfico, extorsión, tráfico de armas y sicariato, además de generar un control social y poblacional en los distintos sectores que conforman el Distrito Especial de Buenaventura.

El control ejercido por la organización criminal La Empresa, se vio interrumpido ante la llegada en el año 2012 de la organización criminal Los Urabeños, entrando las dos organizaciones en una disputa armada, la cual, involucró a la población civil, buscando someter a la población civil de los distintos barrios y comunas de la zona urbana de Buenaventura a acciones mucho más violentas y de mayor control.

Dicho conflicto se presentó durante los años 2012, 2013 y 2014, y por dicha situación, la zona urbana de Buenaventura se vio dividida por el factor de control territorial criminal y convertida en un campo de batalla, presentándose constantes enfrentamientos armados por el control de esos mismos territorios. 
Durante estos años, las organizaciones criminales de la Empresa y Los Urabeños, y los aquí acusados, promovieron y desarrollaron actos de agresión y violencia contra la población, actos que fueron respaldados por la capacidad armada y el miedo infundido, y se convirtieron en autoridades de facto dentro de los barrios bajo su dominio, al imponer normas de convivencia a los pobladores, normas de expansión territorial, extorsiones a las que denominaron impuestos y delimitaron su dominio, denominando los pobladores a esta delimitación barreras invisibles.

\subsubsection{Criterio Complementario}

Los criterios complementarios son aquellos que "se enfocan en evaluar la dificultad que representa investigar y judicializar determinadas situaciones y casos", (Montealegre Lynett, Perdomo, La Rota Uprimmy, Natiello, Zambrano \& Puerto, 2015, p.8 - 11).

Dentro del material probatorio y la evidencia física, se encuentran a varios testigos de los hechos, con quienes cuenta la Fiscalía, quienes informaron cómo podían ver a los habitantes de los distintos barrios de Buenaventura dejar sus casas abandonadas y salir hacía otros barrios o salir de Buenaventura por el temor y el miedo, por los actos de violencia producidos por las organizaciones criminales, en las que tenían parte activa los acusados dentro del caso estudiado, y como muchas de estas casas abandonadas eran utilizadas por miembros de las organizaciones como refugio para la perpetración de otros crímenes.

El Personero Distrital de Buenaventura, dentro del periodo 2012-2014, fue testigo directo de este panorama de violencia y del desplazamiento forzado de personas y familias, quienes a raíz de la violencia generada por la confrontación armada entre las organizaciones criminales La Empresa y Los Urabeños, fueron obligados a cambiar de lugar de residencia.

Por otra parte, el director de la pastoral social, entidad de caridad de la iglesia católica en el Distrito Especial de Buenaventura, indica que dentro de su función social, ha tenido conocimiento de la violencia generada por los dos grupos criminales mencionados, y además ha atendido a la población desplazada, con refugio y con atenciones básicas como alimentación. 
Dentro del escrito de acusación, se afirma que se encuentra, con el relato de las víctimas, quienes indican que cambiaron su lugar de residencia ante la violencia generada por las organizaciones criminales La Empresa y Los Urabeños.

\subsubsection{Análisis del escrito de acusación}

En el caso objeto de estudio, se determina que es la violencia, el actuar de toda la estructura criminal y fueron los diversos actos en los cuales la misma se manifestaba, lo que ocasionaron los desplazamientos de la población civil de los diferentes barrios y comunas de Buenaventura, teniendo como principal acto de violencia, la presencia armada ilegal de estas dos organizaciones.

Artículo 39.Restitución de bienes y cancelación de títulos y registros obtenidos en forma fraudulenta. Cuando se configure la situación excepcional de que trata el artículo 38 anterior, el magistrado con funciones de control de garantías, en audiencia preliminar, surtirá el trasmite de restitución bajo las siguientes reglas:

Para decidir sobre la restitución de los bienes despojados o abandonados forzosamente y la cancelación de los títulos y los registros fraudulentos, el magistrado con funciones de control de garantías dispondrá el trámite de un incidente que se surtirá de conformidad con lo establecido en el inciso segundo del artículo 17 C de la Ley 975 de 2005, para garantizar el ejercicio del derecho de contradicción y oposición de los terceros afectados, quienes deberán demostrar su buena fe exenta de culpa. En caso de que los terceros logren acreditar su buena fe exenta de culpa, el magistrado ordenará en su favor el pago de las compensaciones previstas en el artículo 98 de la Ley 1448 de 2011, con cargo al Fondo de la Unidad Administrativa Especial de Gestión de Restitución de Tierras Despojadas.

Durante el trámite del incidente que se surtirá para la restitución de bienes despojados o abandonados forzosamente, se podrán aplicar las presunciones de despojo previstas en el artículo 77 de la Ley 1448 de 2011, aunque los predios no se encuentre inscritos en el Registro de Tierras Despojadas y Abandonadas Forzosamente. De igual forma, será aplicable la figura de las 
compensaciones en especie y reubicación en los casos en que no sea posible restituir a la víctima del predio despojado según lo previsto en el artículo 97 de la Ley 1448 de 2011, con cargo al Fondo de la Unidad Administrativa Especial de Gestión de Restitución de Tierras Despojadas.

El auto que ordene la restitución deberá contener los aspectos relacionados en el artículo 91 de la Ley 1448 de 201. A esta audiencia se deberá citar a la Unidad Administrativa Especial para la Atención y Reparación Integral a las Víctimas - Fondo para la Reparación de las Victimas o a la Unidad Administrativa Especial de Gestión de Restitución de Tierras Despojadas, según sea el caso. (Colombia, Congreso Nacional de la República, 2012, Ley 1592, p.737 - 738).

Lo anterior significa, que al concertarse los acusados para cometer delitos, al hacer presencia armada en los diferentes barrios y comunas de Buenaventura y además el tener que cumplir un rol dentro de la organización criminal, se consideran como coautores de generar las condiciones que provocaron los desplazamientos forzados en la población de Buenaventura.

Ante unas estructuras criminales, con una cantidad considerable de miembros, recursos bélicos y acciones violentas, tales como los homicidios y desmembramiento de personas, las balaceras o confrontaciones armadas y la misma presencia armada, la única alternativa que le quedaba a la población civil, era la de huir de la zona de riesgo.

Por tal razón, cada uno de los acusados, mediando un acuerdo común y una división de trabajo, sostuvo la política de violencia dirigida contra la población civil, por parte de las organizaciones criminales y ocasionaron que miembros de ésta cambiaran su lugar de residencia.

De esta manera, del escrito de acusación de la Fiscalía Local, se determina que si la población se vio obligada a movilizarse por la violencia generada por las organizaciones criminales, son los miembros de esas mimas organizaciones, los máximos responsables de estos desplazamientos, y lo que se demuestra en dicho escrito, es que son los acusados como miembros de las organizaciones criminales "La Empresa" y "Los Urabeños", quienes al adscribirse al plan criminal de las organizaciones, al compartir sus métodos delictivos y al participar activamente en ellos, promovieron los actos y el panorama de violencia que 
ocasionaron los desplazamientos de los pobladores de los diferentes barrios y comunas de Buenaventura, Valle del Cauca durante los años 2012, 2013 y 2014.

En la Sentencia SP8753-2016 de fecha 29 de junio de 2016, emitida dentro del radicado 39290, magistrado ponente José Francisco Acuña Vizcaya, la Sala de Casación Penal de la Corte Suprema de Justicia, se establece, que el delito de desplazamiento forzado se configura en contextos de macro-criminalidad desarrollados por un agente plural, que en este caso son las organizaciones criminales, ya mencionadas.

Finalmente, en el escrito de acusación, se visualiza, que dentro del contexto de macrocriminalidad desarrollado por las organizaciones criminales que delinquieron en Buenaventura entre el año 2012 y el año 2014 y que se produjo en razón a la participación de los acusados, aproximadamente 9052 familias se desplazaron de las diferentes comunas y barrios de Buenaventura, 1425 durante el año 2012, 3441 familias durante el año 2013 y 4186 familias durante el año 2014, y actualmente, algunas de esas familias, se trasladaron con cada uno de sus miembros, los cuales, incluían niños y ancianos, como víctimas vulnerables de estos hechos.

\subsection{Población, en la que se aplicó el instrumento de investigación, de entrevistas semiestructuradas}

La población que fue seleccionada, para realizar las entrevistas semiestructuradas, dentro del presente trabo de investigación fue la siguiente:

Un funcionario público de la Dirección Nacional de Análisis y Contextos (DINAC), un funcionario público de la Dirección de Políticas Públicas de la Fiscalía General de la Nación, y un funcionario público de la Corte Constitucional, a quienes les fueron aplicadas dichas entrevistas, con el objetivo de conocer su punto de vista en relación con el uso de la metodología de la investigación en contexto, para los crímenes de Lesa Humanidad perpetrados en Colombia,

y en particular, para proceder a identificar e individualizar a los máximos responsables del delito de desplazamiento forzado por la violencia en Colombia, 
En la Dirección de Análisis de Contexto de la Fiscalía General de la Nación, solamente se realizó una sola entrevista a la Dra. Mónica María Suárez Moscoso, quien contestó cada una de las preguntas y suministró Jurisprudencia relacionada con el tema de investigación, como complemento a las respuestas efectuadas.

En la Dirección de Políticas Públicas de la Fiscalía General de la Nación, se realizó una sola entrevista a la Dra. Gina Cabarcas Macia, quien contestó cada una de las preguntas, y colaboró con el suministro de material de apoyo elaborado por la Fiscalía General de la Nación, como son las cartillas que poseen información relacionada con los componentes de la política de priorización, tema relacionado con el tema de investigación, que se desarrolló en el presente trabajo.

Finalmente, en la Corte Constitucional, se realizó una sola entrevista al Dr. Alejandro Ramelli Arteaga, Magistrado Auxiliar, quien contestó cada una de las preguntas y suministró material de apoyo, con el propósito de complementar el primer capítulo del trabajo de investigación.

\subsubsection{Análisis de las entrevistas}

De las entrevistas realizadas, dentro del presente trabajo de investigación, se logra concluir, que la estrategia de investigación en contexto, se fundamenta a partir de diferentes elementos estructurantes de investigación, tales como, la priorización de los delitos de alto impacto, considerados de extrema gravedad, representativos y dañinos para la sociedad civil, y por la manera de ser investigados a partir de la construcción de contextos geográficos, políticos, económicos, y sociales, de los cuales, La Fiscalía General de la Nación, logra recaudar elementos materiales probatorios y evidencia física, para determinar la imputación de los máximos responsables, la judicialización de sus coautores, y la protección de los derechos vulnerados de sus víctimas.

Por otra parte, al entrevistar a los tres funcionarios que conocen y han manejado dicha estrategia de investigación penal, se analiza la importancia de aplicar dicha metodología dentro 
del ámbito de la Justicia Transicional, de acuerdo a lo dispuesto en el Acto Legislativo No. 01 de 2012 y en la Sentencia C - 579 de 2013, la cual, trata de la priorización y de la selección de los delitos más graves y de carácter sistemático, para identificar a los máximos responsables.

Los tres entrevistados coinciden en afirmar, la relevancia de incluir el análisis de contexto, como metodología de investigación en la Justicia Penal Ordinaria, en el momento de analizar la validez de sus fuentes jurídicas, tales como la Directiva No. 01 de 2012, la Directiva 02 de 2012, de la Fiscalía General de la Nación, y del Decreto Ley 16 de 2014, ya que dentro de las mismas, se considera de vital importancia, aplicar dicha metodología, a conductas de extrema gravedad, como son los crímenes de lesa humanidad, dentro del contexto del conflicto armado no internacional y fuera del ámbito de ese mismo contexto.

De las respuestas a las entrevistas, se analiza, que las razones de la aplicación de dicha metodología de investigación aplicada desde el ámbito de la Justicia Transicional, no elimina la posibilidad de que dentro del régimen común de Justicia Ordinaria, se empleen la priorización y la construcción de contextos para poder realizar la investigación de los crímenes de la delincuencia organizada de empresas criminales conjuntas y aparatos organizados de poder, desde el ámbito del conflicto armado nacional e internacional, debido a que los crímenes de lesa majestad poseen dicha connotación jurídica.

En las respuestas, hay coincidencias en lo que respecta a los fines de la Justicia Transicional y que son ajenos a la Justicia Ordinaria, y los cuales, se relacionan directamente con el conflicto armado interno, el carácter grave y masivo de las violaciones a los derechos humanos, la ineficacia de los organismos de justicia penal ordinaria que existen en la actualidad, para hacerle frente a esta clase de crímenes, a la tensión entre la justicia y la paz, se valoran tales aspectos, como justificantes del empleo de la metodología de análisis de contexto.

De las entrevistas, se logra dar un estudio critico a la política criminal del Estado, en lo que respecta a la participación de la Fiscalía dentro del proceso de investigación, de la función constitucional de perseguir el delito, de la necesidad de actuar con eficacia, eficiencia, economía y sostenibilidad fiscal en la utilización adecuada de los recursos existentes para perseguir esta 
clase de delitos, y alcanzar por medio de su aplicación, la seguridad y la convivencia pacífica de nuestra población civil colombiana.

Finalmente, en las respuestas recaudadas, se diferencian los límites tanto de la Justicia Transicional como de la Justicia Ordinaria, la prohibición de la impunidad para ciertos delitos considerados de extrema gravedad, concluyendo que las técnicas de la metodología en contexto no pueden existir independiente la una de la otra, es decir, la priorización sin la construcción de contextos, y la construcción de contextos sin la priorización, debido a que ambos elementos van de la mano, y forman parte de un mismo todo, de conformidad con las fuentes del derecho que los constituyen. 


\section{CONCLUSIONES}

Se debe implementar el sistema de investigación de análisis de contexto, para los crímenes de lesa humanidad perpetrados tanto en Colombia, con el propósito de hacer realidad los fines de la justicia transicional y la justicia restaurativa, a favor de las víctimas, por medio de investigaciones penales exhaustivas y holísticas, para proceder a imputar responsabilidad penal a sus presuntos coautores; debido que para los delitos de menor gravedad, es conveniente implementar como sanciones las amnistías y los indultos, y contar con el apoyo de diversas instituciones, tales como las comisiones de la verdad, y el establecimiento de tribunales especiales ad - hoc, para obedecer a las demandas de justicia de la población civil.

En el caso objeto de estudio, dentro de la presente investigación, se evidencia de que es imposible lograr el estudio de los crímenes de lesa humanidad perpetrados en Colombia, sin contar con una previa estrategia global de investigación, por parte de una unidad investigativa especializada, como es la Dirección Nacional de Análisis y Contextos de la Fiscalía General de la Nación, a través de la implementación de criterios de priorización de situaciones y casos, con

el propósito de llegar a la verdad real, acerca de los hechos acaecidos en la zona de conflicto, construida desde los aspectos políticos, sociales, económicos y culturales.

El término contexto, debe ser analizado por parte de los fiscales de la Dirección Nacional de Análisis y Contextos desde diversas perspectivas y puntos de vista, es decir, como elemento integral de los crímenes de sistema, como método de investigación, como medio de prueba para la Fiscalía General de la Nación, y como un indicio, desde el ámbito del Derecho Internacional de los Derechos Humanos, y del Derecho Internacional Humanitario.

El objetivo principal del uso de las políticas y criterios de priorización de situaciones y casos, dentro del proceso de investigación de los delitos de alto impacto, hace mucho más ágil el trabajo de la Dirección de Análisis y Contextos de la Fiscalía General de la Nación, con el objetivo de obtener respuestas oportunas y adecuadas a las demandas de justicia de las víctimas de estos mismos hechos, cometidos dentro y fuera del contexto del conflicto armado interno en Colombia, con el fin de hacer valer los derechos de las víctimas que han sido conculcados. 
Dentro de los procesos de investigación para crímenes de lesa humanidad perpetrados en Colombia, es necesario utilizar herramientas del procedimiento penal ordinario, tales como el principio de oportunidad, y la aplicación de las garantías procesales, a favor de los procesados, establecidas en la Ley 975 de 2005, y la Ley 1448 de 2011 o Ley de Victimas, con el objetivo de hacer efectivos los derechos de las víctimas, y desmantelar y judicializar a los miembros de estas organizaciones, encontrar la verdad real e histórica, y hacer justicia efectiva.

De conformidad con el análisis realizado en el estudio de caso, incluido en el presente trabajo de investigación, es importante destacar, que para calificar un crimen como de lesa humanidad, dichas conductas deben reunir los elementos requeridos para esta clase de crímenes, es decir, probar que dichas conductas se encuentran en la lista de delitos que forman parte de las disposiciones que forman parte del Derecho Internacional, tales como el Estatuto de Roma de la Corte Penal Internacional, en su artículo $7^{\circ}$., y en la Jurisprudencia de la Corte Interamericana de Derechos Humanos, con el objetivo de lograr la imputación de responsabilidad penal en el derecho interno.

De conformidad con lo preceptuado en el artículo $7^{\circ}$., del Estatuto de Roma de la Corte Penal Internacional, en relación con los crímenes de lesa humanidad, dichas conductas deben obedecer a una violación grave contra los derechos humanos, es decir, diferentes clases de actos inhumanos y de extrema peligrosidad, cometidos como parte de un ataque generalizado o sistemático en contra de la población civil y con conocimiento de dicho ataque, que estén dirigidos contra una multiplicidad de víctimas, y que hagan pate de un plan o de una política preconcebidos, bajo un régimen de terror.

Para demostrar la existencia de un crimen de lesa humanidad, como es el caso de los delitos presentados en el estudio de caso, dichas conductas, deben estar plenamente demostradas por parte del ente acusador, por medio de una investigación integral, en la cual, dichos actos, se encuentren enmarcadas dentro de un contexto de macrocriminalidad, y de esta forma, analizar la situación fáctica ocurrida, y probar que estas mismas conductas se caractericen por formar parte de un ataque sistemático y generalizado en contra de población no combatiente, y que sus coautores, actuaron con premeditación y conocimiento de un plan criminal previo. 
Se deben aplicar, los criterios de priorización de situaciones y casos, dentro del proceso de investigación de crímenes de alto impacto en Colombia, con el objetivo de desarticular las estructuras de delincuencia organizada, para que el proceso de investigación se torne más ágil, debido a que por medio del estudio de la versión del procesado y del testimonio de la víctima, se logran identificar dentro del grupo criminal, su sistema de financiación, sus actividades delincuenciales, su oferta de servicios delictivos y sus contactos a nivel nacional e internacional.

La finalidad de investigar en contexto los crímenes de lesa humanidad perpetrados en Colombia, es la de recobrar la confianza en el aparato jurisdiccional colombiano, desmantelar a los grupos organizados la margen de la ley, y restaurar los derechos y la dignidad de las víctimas, con el propósito de reducir la impunidad, restaurar los valores democráticos, prevenir futuras violaciones a los Derechos Humanos, y al Derecho Internacional Humanitario, y lograr los fines de un Estado Social y Democrático de Derecho.

Por medio de la utilización de esta estrategia de investigación, se busca estudiar y analizar el crimen, con gran amplitud a nivel cognitivo, por tal razón, y tal como se evidenció en el análisis que del caso realizó la Fiscalía Local de Buenaventura, dicho estudio, debe efectuarse a nivel interdisciplinario, para poder llegar a la verdad de los hechos perpetrados, para proceder a identificar a los máximos responsables y hacer realidad los fines de la justicia transicional.

Dentro del análisis del contexto, que realiza el Fiscal de las conductas realizadas por los grupos armados organizados al margen de la ley, se debe precisar el objetivo y el contenido temporal y geográfico del plan o acuerdo criminal, para demostrar, que se trata de un propósito común para todos los miembros de la Empresa Criminal Conjunta, esto significa, que dicho plan debe estar dirigido a la comisión de delitos que pudieron acordarse antes o durante la marcha, pues el mismo, puede llegar a deducirse de las circunstancias del caso y no ser expreso.

Mediante la priorización y el análisis contextual del fenómeno de la macrocriminalidad y la persecución de los máximos responsables, se logran recaudar elementos materiales probatorias, y evidencia física suficiente, para imputar responsabilidad penal, de conformidad con el daño que fue causado a sus víctimas, por parte de los coautores de estos hechos atroces. 


\section{REFERENCIAS BIBLIOGRÁFICAS}

\section{Doctrina}

Ahumada Méndez, L.S., Carvajal Bernal, A., García Rincón, B.S., Martínez Mosquera, J.I., Riveros Leal, E., Rojas Sánchez, O.C., (2010). Estado del arte de las metodologías de trabajo. Fundamentadas en la Pedagogía Social. Estrategias Aplicadas a la atención de niñas, niños y jóvenes en situación de desplazamiento forzado en las Instituciones distritales de Bogotá, D.C., Bogotá, D.C.: Universidad Cooperativa de Colombia. Editorial Universidad Cooperativa de Colombia. (Educc).

Acnur (2001). Compilación sobre desplazamiento forzado. Normas doctrina y Jurisprudencia nacional e internacional. $1^{\text {a }}$. Edición. Bogotá, D. C.: Oficina en Colombia el Alto Comisionado de las Naciones Unidas para los Derechos Humanos, Alto Comisionado de las Naciones Unidas para los Refugiados Oficina en Colombia y Consultoría para los Derechos Humanos y el Desplazamiento - Codhes -, pp. 545.

Acnur (2006). Balance la política pública de prevención, protección y atención al Desplazamiento interno forzado en Colombia agosto 2002 - agosto 2004. $1^{a}$. Reimpresión. Bogotá, D. C.: Alto comisionado de las naciones unidas Para los refugiados Oficina para Colombia.

Alpargatero Ulloa, L. L. (2011). La política pública del desplazamiento forzado en Colombia: Una visión desde el pensamiento complejo. Bogotá, D.C.: Editorial Universidad del Rosario. Primera Edición.

Álvarez Díaz, O.L. (2008). Estado Social del Derecho, Corte Constitucional y Desplazamiento Forzado en Colombia. Bogotá, D.C: Siglo del Hombre Editores. Universidad Nacional de Colombia. IEPRI. Pontificia Universidad Javeriana. Instituto Pensar.

Ambos, K. Crímenes de Lesa Humanidad y La Corte Penal Internacional. Revista General de Derecho Penal 17. pp.30. 
Ambos, K. (2005). La parte general del Derecho Penal Internacional. Bases para una elaboración dogmática. pp.594.Bogotá, Colombia: Editorial Temis S.A.

Ambos K, y Malarino E. (2008) Colombia. En Aponte Cardona, A. Jurisprudencia Latinoamericana sobre Derecho Penal Internacional. Con informes adicionales de España e Italia. pp. 159 - 211. Bogotá, Colombia: Editorial Temis, S.A.

Ambos, K. Malarino E., Elsner, G. (2011). Sistema Interamericano de protección de los derechos humanos y derecho penal internacional - Tomo II. Desplazamiento Forzado, sistema interamericano y derecho penal interno: Hacia una Confluencia racional y consistente de diversos ámbitos de protección de derechos humanos. Montevideo, Uruguay: Konrad Adenauer Stiftung. Georg - August - Universitat - Gottingen, Instituto de Ciencias Criminales - Departamento de Derecho Penal Extranjero e Internacional. pp. 563.

Aponte Cardona, A. (2008). Colombia. En K. Ambos \& E. Malarino, Jurisprudencia Latinoamericana sobre Derecho Penal Internacional. (pp.159 - 213). Bogotá- Colombia: Editorial Temis S.A.

Aponte Cardona, A. (2011). Colección Profesores. Persecución Penal de Crímenes Internacionales. Diálogo Abierto entre la Tradición Nacional y el Desarrollo Internacional. Bogotá, D.C.: Grupo Editorial Ibáñez. Fundación Konrad Adenauer. Pontificia Universidad Javeriana.

Aponte Cardona, A. (2014). Derecho penal y Filosofía (Vol. I). Bogotá, D.C. - Colombia: Pontificia Universidad Javeriana, pp.894.

Acquaviva G. (2.011, Abril) Políticas Legales y de Protección Series de Investigación. Desplazamiento Forzado y Crímenes Internacionales. Ginebra: Suiza. División de 
Protección Internacional. Alto Comisionado de las Naciones Unidas para los Refugiados ACHNUR, pp.28.

Barbosa Catillo, G., Bernal Pulido, C., Cataño, G., Correa Henao, M., Fajardo Arturo, L.A., Mejía Azuero, J.C., Velasco Chaves, E., (2015). El análisis de contexto en la Investigación penal: critica del trasplante del derecho internacional al derecho interno. Primera Edición. Bogotá, Colombia: Universidad Externado de Colombia. pp.584.

Blaxter, L, Hughes, C., Tight, M. (2.005). Cómo se hace una Investigación. Barcelona - España: Editorial Gedisa, S.A.

Benjumea Rúa, A.M. (2002). Prevención del desplazamiento forzado. Medellín - Colombia: Serie Cartillas IPC.

Conde Romero, A.G. (2013). Justicia Transicional, Justicia Penal Ordinaria o Justicia Restaurativa. Recuperado el 6 de noviembre de 2015, de http://www.acore.org.co/index.php/noticias/item/1537-justicia-transicional-justicia-penalordinaria-o-justicia-restaurativa

Correa de Andreis, A. (2009). Desplazamiento Interno Forzado. Restablecimiento Urbano e Identidad Social. Bogotá, D.C.: Barranquilla - Colombia, Uninorte.

Courtis, Ch. (2009). Ecos Cercanos. Estudios sobre derechos humanos y justicia. Bogotá, D.C.: Grupo IDEAS. Universidad de los Andes. Facultad de Derecho.pp.90.

Churruca, C. (2010). Desplazamiento en Colombia. Prevenir, asistir, transformar. Cooperación Internacional e iniciativas locales. La Carreta Editores E.U. Medellín, Colombia.

Defensoría del Pueblo. (2001). Diagnóstico de población desplazada y comunidades de recepción en seis departamentos de Colombia. OIM Organización Integral para las Migraciones. 
Defensoría del Pueblo. (2014). Vigésimo Primer Informe del Defensor del Pueblo al Congreso de la Republica. Los derechos Humanos están presentes en todos los momentos de la vida.pp. 577

Del Campo Steta, L.M. (2006). Genocidio, Crímenes de Guerra y Crímenes de Lesa Humanidad. Compendio Temático sobre Jurisprudencia del Tribunal Penal Internacional para la Antigua Yugoslavia. (lera. ed.). Ciudad de México - México: Universidad Iberoamericana. pp. 764.

Departamento para la Prosperidad Social. (2013) Basta Ya. Colombia: Memorias de Guerra y Dignidad. Informe General Grupo de Memoria Histórica. Centro Nacional de Memoria Histórica.

Fiscalía General de la Nación. (2015) ¿Quiénes somos? Recuperado el 6 de noviembre de 2015, de http://www.fiscalia.gov.co/colombia/la-entidad/quienes-somos/

Fiscalía General de la Nación. (2015). Priorización. Nuevo sistema de investigación penal. $\begin{array}{llllll}\text { Recuperado el noviembre de } 6 \text { de } & \text { de }\end{array}$ http://www.fiscalia.gov.co/colombia/priorizacion/priorizacion-nuevo-sistema-deinvestigacion-penal/

Fiscalía General de la Nación. (2015) Unidad Nacional de Análisis y Contextos. Recuperado el 6 de noviembre de 2015, de http://www.fiscalia.gov.co/colombia/priorizacion/unidadnacional-de-analisis-y-contextos/

Forer, A., López Díaz, C., Errandonea, J., Cardona, J.P. y González, D. (2010). Acerca de los crímenes de lesa humanidad y su aplicación en Colombia. Bogotá, D.C. - Colombia: Embajada de la República Federal de Alemania, pp.47. 
Giraldo, V.E., et al. (2004). Trata de Personas y Desplazamiento. Bogotá, D.C. - Colombia: Memo O \& Cía. Ltda.

Hernández Libreros, E.L. (1.999). Protección a los desplazados en Colombia, Marco Jurídico y Mecanismos de Protección, Eficacia y Utilidad. Tesis para optar al título de Abogado no publicada, Universidad Externado de Colombia, Facultad de Derecho, Bogotá, D.C.

Hernández Mondragón, M. (2007). El Desplazamiento Forzado en Colombia. Bogotá, Colombia: Defensoría del Pueblo, Colombia. Red Nacional de Promotores de Derechos Humanos, pp.192.

Las victimas del desplazamiento forzado en Colombia. (2015). El desplazamiento forzado, una violación de los derechos humanos y un crimen contra la humanidad. Recuperado el 6 de noviembre de 2015, de http://ilsa.org.co:81/biblioteca/dwnlds/experiencias/5/1.pdf

Lozano Bedoya, C.A. (2009). Justicia para la dignidad. La opción por los derechos de las víctimas. Consejería en Proyectos. - PCS. Bogotá, D.C.: Primera Edición. pp.452.

Martínez Miguélez, M. (2013). Ciencia y Arte en la Metodología Cualitativa. Métodos hermenéuticos, métodos fenomenológicos, métodos etnográficos. (Segunda edición). México, D.F.: Editorial Trillas, S.A de C.V.pp. 365.

Montaner, B. (1997). Derechos fundamentales. Recuperado el 6 de noviembre de 2015, de http://www.derecho.com/c/Derechos_fundamentales

Montealegre Lynett, E., Perdomo Torres, J.F., La Rota Uprimmy, M.E., Natiello, P., Brooks, K., Zambrano, L., y Puerto, M. (Agosto, 2015). Componentes básicos de la política de priorización. Cartilla 1. Herramientas No. 1, 2, 3, 4, 5,8. (pp.8 - 11). Fiscalía General de la Nación: Bogotá, D.C. - Colombia. 
Naciones Unidas Derechos Humanos, Oficina del Alto Comisionado para los Derechos Humanos (2015). ¿Qué son los derechos humanos? Recuperado el 6 de noviembre de 2015, de http://www.ohchr.org/SP/Issues/Pages/WhatareHumanRights.aspx

Naciones Unidas. (2016). Instrumentos del Estado de Derecho para sociedades que han salido de un conflicto. Iniciativas de enjuiciamiento. Nueva York - Estados Unidas y Ginebra Suiza: Oficina del Alto Comisionado de las Naciones Unidas para los Derechos Humanos, pp. 54.

Osorio Pérez, F.E. (1993). La Violencia del Silencio. Desplazados del campo a la Ciudad. Bogotá, D.C.: Edición CODHES. Pontificia Universidad Javeriana.

Presidencia de la República. (1999). Atención a la población desplazada por el conflicto armado. Compendio de políticas y normas. Primera Edición. Bogotá, D.C.: Red de Solidaridad Social.

Ramelli Arteaga, A. (2011). Jurisprudencia penal internacional aplicable en Colombia. Colombia - Bogotá, D.C.: Universidad de los Andes, pp.660.

Ramelli Arteaga, A. (2017, 23 de marzo). Peritaje rendido ante la Corte Interamericana de Derechos Humanos por Alejandro Ramelli Arteaga en el asunto Pacheco León y otros Vs. Honduras. (Caso No. 12.585).57 Periodo Extraordinario de Sesiones. Guatemala Ciudad de Guatemala.p.112.

Rojano Mercado, J. (2009, 19 de diciembre).Hermenéutica: Enfoque plural en la investigación cualitativa. Recuperado el 18 de agosto de 2018, de https://www.monografias.com/trabajos78/hermeneutica-enfoque-plural-tradicioncualitativa/hermeneutica-enfoque-plural-tradicion-cualitativa2.shtml 
Romero, M.A. et. al. (2006) Desplazamiento Forzado y Políticas Publicas. Comisión de Seguimiento a la Política Pública sobre Desplazamiento Forzado. Consultoría para los Derechos Humanos y el Desplazamiento. CODHES, Bogotá, D.C. Sentencia T - 025. Primer Informe.

Romero Y. (2013) La hermenéutica como paradigma cualitativo emergente en el abordaje de la salud bucal. Hermeneutic like emergent qualitative paradigm in the oral health boarding. $\begin{array}{llllll}\text { Recuperado el de } 24 \text { junio de } & \text { de }\end{array}$ http://servicio.bc.uc.edu.ve/odontologia/revista/vol13-n2/art07.pdf.

Sandoval Mesa, J.A. Principio de legalidad y Lesa Humanidad en el Estatuto de Roma de 1998.Bogotá, D.C: Universidad Militar Nueva Granada.

Sastoque Poveda, L.F.O.P., Parra Rozo, O., Bejarano Varela, A. M. (2008). Módulos 56. Metodología de la Investigación Jurídica y Socio jurídica. Bogotá, D.C.: Universidad Santo Tomas.pp.44.

Talledo Thais, V. A. (2015). Algo más. El Derecho a la Verdad. Recuperado el 6 de noviembre de 2015, de http://www.derechos.net/esp/algomas/talledo.html

Tassara, C, Jiménez Castrillón, D.L., Grande L, Zuluaga Torres, Y. (1999). El desplazamiento por la violencia en Colombia. Experiencias, análisis y posibles estrategias de atención en el Departamento de Antioquia. Memorias del Foro Internacional "Desplazados internos en Antioquia”, Medellín, 27 - 28 de Julio de 1. 998. Medellín, Colombia: ACNUR, CISP y ECOE Ediciones, pp.212.

Tolbert, D. (2015). ¿Qué es la Justicia Transicional? Recuperado el 6 de noviembre de 2015, de https://www.ictj.org/es/que-es-la-justicia-transicional 
Universidad Externado de Colombia, (2007). Cátedra Unesco. Derechos Humanos Y violencia: Gobierno y gobernanza. El desplazamiento forzado interno en Colombia un desafío a los derechos humanos. Bogotá, D.C, Colombia: Alfacolor Editores Ltda., pp.610.

Universidad Sergio Arboleda, Artículos Maestría en Derecho (2013). Del Estado de Cosas Inconstitucional. Recuperado el 6 de noviembre de 2015, de http://derechojusticiaypaz.blogspot.com.co/2013/06/del-estado-de-cosasinconstitucional.html

Unidad Nacional de Fiscalías para la Justicia y la Paz, Fiscalía General de la Nación. (2012).” Esquema Ley 975. Guía de consulta sobre la Ley 975 de 2005 en el contexto del proceso de paz en Colombia" Recuperado el día 6 de noviembre de 2015, de http://www.fiscalia.gov.co:8080/Esquema975.htm

Valencia Villa, A. (2007). Derecho Internacional Humanitario. Conceptos básicos. Infracciones en el conflicto armado colombiano.pp.81 - 92.

Valencia, C. (2005). Población desplazada, derechos y ofertas. Bogotá, D.C.: ACNUR.ASDI.

Valencia Villamizar, D. (2013). Protocolo para la elaboración, seguimiento y evaluación de proyectos de investigación en maestrías y doctorados. Bogotá, D.C., Colombia: Facultad de Derecho de la Universidad Santo Tomás.

Vidal López, R.C. (2007). Derecho Global y Desplazamiento Interno. Creación, uso y desaparición del desplazamiento forzado por la violencia en el Derecho contemporáneo. Bogotá, D.C., Colombia: Pontificia Universidad Javeriana, pp.272.

Vidal López, R.C. (2009). Desplazamiento Forzado y construcción de paz en Colombia.2009 2010 Bogotá, D.C., Colombia: (CODHES). Facultad de Ciencias Jurídicas de la Pontifica Universidad Javeriana. 
Vidal López, R.C. (2007). Derecho Global y Desplazamiento Interno. Creación, uso y desaparición del desplazamiento forzado por la violencia en el derecho contemporáneo. Bogotá, D.C., Colombia: Pontificia Universidad Javeriana, pp.272.

Villaraga Sarmiento, A. (2008). Antecedentes y elementos de diagnóstico: rasgos del conflicto armado y del derecho humanitario en Colombia. En Villaraga Sarmiento, A., Derecho Internacional Humanitario Aplicado. (pp.257 - 280).TM Editores: Oficina el Alto Comisionado para la Paz, Pontificia Universidad Javeriana, Fundación Konrad Adenauer y Comité Internacional de la Cruz Roja.

Werle, G. y Maculan, E. (2011). Tratado de derecho penal internacional. (2ª . ed.). Bogotá, D.C., Colombia: Universidad de los Andes, pp.422

Werle, G., Burchards, W., Jessberger, F., Luders, B., Meseke, S. y Nerlich, V. (2005) Tratado de Derecho Penal Internacional. Valencia, España: Tirant Lo Blanch, pp.739.

Wikipedia. La enciclopedia libre. (2015, 27 de octubre) Crimen contra la humanidad. $\begin{array}{llllll}\text { Recuperado el noviembre de } 6 \text { de } & \text { de }\end{array}$ https://es.wikipedia.org/wiki/Crimen_contra_la_humanidad

Wikipedia. La enciclopedia libre. (2015, 5 de noviembre) Derechos Constitucionales. $\begin{array}{llllll}\text { Recuperado el noviembre de } 6 \text { de } & \text { 2015, }\end{array}$ https://es.wikipedia.org/wiki/Derechos_constitucionales

Wikipedia. La enciclopedia libre. (2015, 2 de noviembre) Derecho Internacional Humanitario. Recuperado el 6 de noviembre de 2015, de https://es.wikipedia.org/wiki/Derecho_internacional_humanitario

Wikipedia. La enciclopedia libre. (2015, 7 de octubre). Desplazados Internos. Recuperado el 6 de noviembre de 2015, de https://es.wikipedia.org/wiki/Desplazados_internos 


\section{Normatividad}

Arboleda Vallejo M., Colombia (2017, julio) Código Penal y de Procedimiento Penal Básico (Trigésima primera edición) Bogotá, D.C. -Colombia: Editorial: UniAcademia LEYER., pp.730.

Arboleda Vallejo, M., Colombia (2014). Código Penal y de Procedimiento Penal Básico. (Vigésima sexta edición). Bogotá, D.C - Colombia: Editorial UniAcademia LEYER., pp.656.

Colombia, Fiscalía General de la Nación (2012, 4 de octubre), "Directiva 0001 de 04 de Octubre de 2012. Por medio de la cual se adoptan unos criterios de priorización de situaciones y casos, y se crea un nuevo sistema de investigación penal y de gestión de aquéllos en la Fiscalía General de la Nación”, 04 de Octubre de 2012, Bogotá, D.C., 110.

Colombia, Fiscalía General de la Nación (2015, 9 de diciembre), "Directiva 0002 de 09 diciembre de 2015, por medio de la cual se amplia y modifica la Directiva 01 de 2012, se desarrolla el alcance de los criterios de priorización de situaciones y casos, y se establecen lineamientos para la planificación y gestión estratégica de la carga de trabajo y de la investigación penal en la Fiscalía General de la Nación", 9 de Diciembre de 205, Bogotá, D.C.

Colombia, Congreso Nacional de la República (2012, 3 de diciembre), "Ley 1592 de 2012, por la cual se dictan disposiciones para la reincorporación de miembros de grupos armados organizados al margen de la ley, que contribuyan de manera efectiva a la consecución de la paz nacional y se dictan otras disposiciones para acuerdos humanitarios y se dictan otras disposiciones", en Diario Oficial, núm. 48633,3 de diciembre de 201, Bogotá, D.C. 
Colombia, Congreso Nacional de la República (2011, 10 de junio), "Ley 1448 de 2011, por la cual se dictan medidas de atención, asistencia y reparación integral a las víctimas del conflicto armado interno y se dictan otras disposiciones”, en Diario Oficial, núm. 48096, 10 de junio de 2011, Bogotá, D.C.

Colombia, Congreso Nacional de la República (2005, 25 de julio), "Ley 975 de 2005, por la cual se dictan disposiciones para la reincorporación de miembros de grupos armados organizados la margen de la ley, que contribuyan de manera efectiva a la consecución de la paz nacional y se dictan otras disposiciones para cuerdos humanitarios", en Diario Oficial, núm.45980, de julio 25 de 2005, Bogotá, D.C

Colombia, Congreso Nacional de la República (1997, 18 de julio), "Ley 387 de 1997, por la cual se adoptan medidas para la prevención del desplazamiento forzado, la atención, protección, consolidación y estabilización socioeconómica de los desplazados internos por la violencia en la República de Colombia”, en Diario Oficial, 18 de julio de 1997, Bogotá, D.C.

Colombia, Ministerio de Justicia y del Derecho (2013, 26 de diciembre), "Decreto Número 3011 de 26 de diciembre de 2013, por el cual se reglamentan las leyes 975 de 2005, 1448 de 2011 y 1592 de 2012”, en Diario Oficial, núm. 49016, 27 de Diciembre de 2013, Bogotá, D.C.

Colombia, Congreso Nacional de la República (2012, 31 de julio).”Acto legislativo No. 01 de 2012, por medio del cual se establecen instrumentos jurídicos de justicia transicional en el marco del artículo 22 de la Constitución Política y se dictan otras disposiciones", en Diario Oficial, 31 de julio de 2012, Bogotá, D.C.

Colombia, Fiscalía General de la Nación (2014, 30 de julio), "Resolución No. 01343 del 30 de julio de 2014, por medio de la cual se reglamentan el Comité Nacional y los Comités Seccionales de Priorización de Situaciones y Casos, y se asignan diversas funciones para la implementación de la política de priorización”, 30 de julio de 2014, Bogotá D.C. 
Colombia, (2016, diciembre 30), "Ley 1820 de diciembre 30 de diciembre de 2016, por medio de la cual se dictan disposiciones sobre amnistía, indulto y tratamientos penales especiales y otras disposiciones", en Diario Oficial, núm. 50.102, 30 de diciembre de 2016, Bogotá, D.C.

\section{Jurisprudencia}

San José de Costa Rica, Corte Interamericana de Derechos Humanos (2006, 26 de septiembre), “Caso Almonacid Arellano y otros v. Chile", sentencia de fondo del 26 de septiembre de 2006, pp.77.

San José de Costa Rica, Corte Interamericana de Derechos Humanos (2005, 15 de septiembre), "Caso de la Masacre de Mapiripán vs. Colombia”, sentencia de fondo del 15 de septiembre de 2005, pp.129.

San José de Costa Rica, Corte Interamericana de Derechos Humanos, (2004, 5 de Julio) “Caso 19 Comerciantes vs. Colombia”, sentencia de fondo del 5 de julio de 2004, pp.256

San José de Costa Rica, Corte Interamericana de Derechos Humanos, (2006, $1^{\circ}$. De julio) “Caso de las Masacres de Ituango Vs. Colombia”, sentencia de fondo del 1 de julio de 2006, pp.32.

Colombia, Corte Constitucional (2014, 16 de diciembre), "Sentencia T - 971 de 2014, M.P. Palacio Palacio, J.I., Bogotá, D.C.

Colombia, Corte Constitucional (2016, 19 de julio), "Sentencia T - 380”, M.P. Calle Correa, M.V., Bogotá, D.C.

Colombia, Corte Constitucional (2013, 12 de noviembre), "Sentencia T - 795", M.P. Mendoza Martelo, G.E., Bogotá, D.C. 
Colombia, Corte Constitucional (2004, 22 de enero), "Sentencia T - 025", M.P. Cepeda Espinosa, M.J., Bogotá, D.C.

Colombia, Corte Constitucional (2016, 27 de mayo), "Sentencia T- 280 A", M.P. Vargas Silva, L.E., Bogotá, D.C.

Colombia, Tribunal Superior de Bogotá, D.C., Sala de Justicia y Paz (2014, 20 de noviembre), “Sentencia No. 110012252000201400027”, M.P. González R., L.M., Bogotá, D.C.pp.2261. 


\section{ANEXOS}

1. Escrito de acusación de la Fiscalía Local de Buenaventura de un caso de concierto para delinquir y desplazamiento forzado por la violencia agravado, dentro de los enfrentamientos entre los grupos criminales la empresa y los urabeños en dicha zona de conflicto.

\begin{tabular}{|c|c|c|c|c|c|}
\hline \multicolumn{4}{|c|}{ DETENIDO $\quad \mathrm{SI}_{2} \mathrm{xxx}_{\ldots} \mathrm{NO}_{-}$} & & \\
\hline \multicolumn{6}{|c|}{ CON ALLANAMIENTO SI_ } \\
\hline \multicolumn{6}{|c|}{ Departamento: $\quad$ Valle del Cauca } \\
\hline \multicolumn{2}{|c|}{ Municipio } & 3uenaver & & & \\
\hline \multicolumn{2}{|l|}{ Fecha: } & $7 / 08 / 20$ & & & \\
\hline \multicolumn{2}{|l|}{ Hora: } & $9: 11$ & & & \\
\hline \multicolumn{6}{|c|}{ Código único de la investigación y delito(s) } \\
\hline 11 & 001 & 60 & 00027 & 2014 & 00169 \\
\hline Dpto. & Municipio & Entidad & Unidad Receptora & Año & Consecutivo \\
\hline \multicolumn{4}{|l|}{ Delito } & & Artículo \\
\hline \multicolumn{4}{|c|}{ Concierto para Delinquir Agravado } & & Artículo 340 C.P. \\
\hline \multicolumn{4}{|c|}{ Desplazamiento Forzado Agravado } & & Artículo 180 C.P. \\
\hline
\end{tabular}

Fundamento de la acusación (fáctico y jurídico)

\section{1) Acusación fáctica}

Los hechos objeto de la acusación, ocurrieron en la zona urbana del Distrito Especial de Buenaventura, Valle del Cauca durante los años 2012, 2013 y 2014.

De acuerdo a los elementos materiales probatorios e información legalmente obtenida, se puede afirmar con probabilidad de verdad, que los aquí acusados hicieron parte de las organizaciones criminales La Empresa y Urabeños (posteriormente autodenominados 
Gaitanistas), participando del plan criminal de las mismas de manera importante y a través de esa participación, sostuvieron una política de violencia, la cual se encontraba dirigida contra la población y tenía como finalidad mantener el control criminal en los distintos barrios y comunas del Distrito Especial de Buenaventura, esa política de violencia materializada en acciones, ocasionó el cambio de residencia de más de 9000 familias durante los años 2012, 2013 y 2014.

De acuerdo a los elementos materiales probatorios, evidencia física e información legalmente obtenida, se logró establecer la presencia en los distintos barrios y comunas de Buenaventura de la organización criminal La Empresa a través de hombres armados, quienes desarrollaban actividades ilícitas y sometían a la población a su arbitrio. Desde el año 2009, esta organización ocupó los espacios dejados por las Autodefensas Unidas de Colombia luego del proceso de desmovilización, logrando consolidarse como la organización criminal dominante en el territorio, pues poseía el control de las actividades criminales de narcotráfico, extorsión, tráfico de armas y sicariato, además de generar un control social y poblacional en los distintos sectores que conforman el Distrito Especial de Buenaventura.

Ese control y la hegemonía de la organización criminal La Empresa, se vio perturbada ante la llegada en el año 2012 de la organización criminal Los Urabeños, entrando las dos organizaciones en una disputa armada, la cual involucró a la población civil, sometiendo las dos organizaciones a los habitantes de los distintos barrios y comunas de la zona urbana de Buenaventura a acciones mucho más violentas y mayores controles.

Esta guerra se evidenció durante los años 2012, 2013 y 2014, producto de ésta, la zona urbana de Buenaventura se vio dividida por el factor de control territorial criminal y convertida en un campo de batalla, así entonces, existían unos barrios que eran de dominio de la organización criminal La Empresa y unos barrios que eran de dominio de la organización criminal Los Urabeños, presentándose constantes enfrentamientos armados por el control de estos territorios

Durante estos años, las organizaciones criminales ya mencionadas y específicamente los aquí acusados, quienes eran miembros de las citadas organizaciones y dentro de las mismas 
ocupaban un rol preponderantemente violento, promovieron y desarrollaron actos de agresión y de violencia contra la población y respaldados por la capacidad armada y el miedo infundido, se convirtieron en autoridades de facto dentro de los barrios bajo su dominio, imponiendo normas de convivencia a los pobladores, normas de expansión territorial, extorsiones a las que denominaron impuestos y delimitaron su dominio, denominando los pobladores a esta delimitación barreras invisibles.

Los actos violentos promovidos por estas organizaciones y los acusados durante su confrontación armada y durante el dominio territorial criminal ejercido en los distintos barrios y comunas, se pueden enumerar de la siguiente manera:

Presencia armada en los diferentes barrios y comunas de Buenaventura: La presencia de personal armado de las organizaciones, era visible en los diferentes barrios de Buenaventura, prestando guardia, con miras a impedir el ingreso de la otra organización criminal o simplemente para mostrar poderío y generar temor y miedo en la población y mantenerla bajo su control, para esto utilizaban armas de corto alcance como pistolas, revólveres, escopetas y de largo alcance como fusiles e incluso granadas de fragmentación.

Control territorial y poblacional: Las organizaciones criminales o delincuenciales (Empresa -Urabeños (Gaitanistas)), como medida frente al conflicto que libraban, empezaron a establecer controles en los barrios bajo su dominio, así por ejemplo, se establecieron las denominadas barreras invisibles, determinando aquellos puntos por los que sólo habitantes del barrio y/o personas conocidas por la organización podía transitar. Igualmente, se establecieron reglas de convivencia, prohibiendo las riñas entre vecinos y se establecieron requisas para familiares y amigos que venía de visita al barrio, se prohibieron las relaciones con los organismos policiales y militares y se advertía sobre las consecuencias de delatar a la organización ante las autoridades, se establecieron tarifas de multas o sanciones por no cumplir las reglas de la organización y se controlaba la construcción de nuevas viviendas o su remodelación, imponiendo tarifas de cobro (extorsión) frente a esta actividad.

Enfrentamientos: La confrontación entre las organizaciones criminales, motivada por 
obtener el control y dominio de los distintos barrios de Buenaventura, generaba enfrentamientos armados, los que la comunidad identificaba como balaceras, estos enfrentamientos producían temor y zozobra, ya que muchas veces según la información obtenida, se producía disparos indiscriminados, lo que representaba un gran peligro para la comunidad.

Homicidios: toda confrontación armada produce muertes, de los elementos materiales probatorios e información con la que cuenta la Fiscalía General de la Nación, se puede inferir que se produjeron múltiples homicidios, no sólo de personas involucradas en el conflicto, sino de personas ajenas a la confrontación, que no cumplían con las exigencias de las organizaciones, que sobrepasaban la barreras territoriales establecidas o que eran sospechosas de pasar información a la organización enemiga o a la autoridad.

Homicidio bajo la modalidad de desmembramiento: Una de las modalidades de homicidio utilizadas por estas organizaciones, con miras a sembrar terror en sus enemigos y en la población, es el desmembramiento de personas, arrojando las partes corporales como cabeza, tronco, piernas y brazos en distintos sectores de la ciudad. Según registros oficiales durante los años 2012, 2013 y 2014 se presentaron alrededor de 38 casos de cuerpos desmembrados, cuyas partes corporales fueron encontradas en distintos sectores de la ciudad y en el mar.

Extorsión: Uno de los principales actos de violencia desplegados, es las exigencias económicas que estas organizaciones le hacía a los comerciantes, moto - taxistas, pescadores, trasportadores y en sí a cualquier persona perteneciente a un gremio que generara ingresos económicos, para que colaboraron con lo que ellos llamaron causa, exigencias económicas que denominaron impuesto y que se fueron extendiendo a los habitantes de la zona, llegando incluso a realizar cobros por cada casa.

Constreñimiento para delinquir y reclutamiento de menores: La confrontación armada entre estas organizaciones delincuenciales, generaron necesidades de personal, al punto que se trataba de convencer a los jóvenes y menores de Buenaventura, para que ingresaran a las filas de las organizaciones, en otras ocasiones, mediante coacción se trataba de reclutar. 
Amenazas: Constantes eran las amenazas para la población, principalmente para que no suministraran información a las autoridades, no tuvieran relación con el bando enemigo o para que se comportaran de cierto modo frente a la presencia de la organización.

Desaparición forzada: Una de las prácticas constantes de estas organizaciones, es la desaparición de personas, algunos testigos ilustran sobre fosas en las que se enterraban los cadáveres de personas asesinadas por la organización, algunos de éstos desmembrados, igualmente ilustran sobre el depósito de cadáveres en el mar, algunos de ellos aún no han sido hallados.

Secuestro: Las organizaciones registran durante este periodo, una práctica de secuestro extorsivo, en donde retenían a las personas por un corto periodo de tiempo, con el fin de hacerle exigencias económicas concretas.

Rumores, grafitis y panfletos: Algunas víctimas relacionan, que una situación provocada por las organizaciones, era la proliferación de rumores sobre el poderío armado, panfletos amenazantes y algunos grafitis.

Afectación cultural: se prohibieron algunos rituales y ceremonias religiosas y costumbres de la población afro- descendiente, en razón a la conveniencia de las organizaciones criminales.

Los aquí acusados, como miembros de las organizaciones criminales La Empresa y Los Urabeños (Gaitanistas), a través del desempeño de sus roles contribuyeron a la construcción y mantenimiento de este panorama de violencia, que obligó a la población civil a cambiar su lugar de residencia, con el fin de salvaguardar su vida y su integridad personal, viendo afectada entonces la población su libertad individual, pues no se trasladaban de un barrio a otro o huían de Buenaventura hacía otras localidades del país por su propio deseo o por buscar mejores oportunidades, ya que se movilizaban por la presión y la violencia generada por los acusados y sus organizaciones criminales.

Según registros de la Unidad para la Atención y Reparación Integral a las Víctimas 
(UARIV), durante los años 2012, 2013 y 2014, fueron incluidas en el Registro Único de Víctimas, como víctimas de Desplazamiento Forzado provocado por el panorama de violencia generado por las organizaciones criminales La Empresa y Los Urabeños (Gaitanistas), 9052 declaraciones, que corresponden a núcleos familiares desplazados, es decir, que según los registros en Buenaventura alrededor de 9052 familias cambiaron su lugar de residencia, en razón a la violencia ya ilustrada.

La Fiscalía General de la Nación, cuenta con 230 denuncias de personas que indican haber cambiado su lugar de residencia por la violencia generada por estas organizaciones criminales y sus miembros.

Existen más de 200 constancias expedidas por los presidentes de la Juntas de Acción Comunal de los diferentes barrios de Buenaventura, que dan cuenta del éxodo de la población producto de la guerra entre estas organizaciones criminales La Empresa y Urabeños.

Actas levantadas por la Secretaria de Gobierno Distrital, que dan cuenta de la activación de mecanismos para la atención de emergencias ante los desplazamientos masivos de la población, producto de las acciones violentas generadas por las organizaciones criminales La Empresa y Urabeños y sus miembros.

Testigos con los que cuenta la Fiscalía, informan cómo podían ver a los habitantes de los distintos barrio de Buenaventura dejar sus casas abandonadas y salir hacía otros barrios o de Buenaventura por el temor y la zozobra provocada por los actos de violencia producidos y promovidos por las organizaciones, en las que tenían parte activa los acusados, muchas de estas casas abandonadas eran utilizadas por miembros de las organizaciones como refugio o como escenarios para la comisión de crímenes.

El Personero Distrital de Buenaventura, para el periodo 2012-2014, cuenta cómo en su función de garante de los derechos humanos de la población de Buenaventura, fue testigo directo de este panorama de violencia y del desplazamiento masivo de personas y familias, quienes a raíz de la violencia generada por la confrontación armada entre las organizaciones criminales La 
Empresa y Los Urabeños, se vieron obligados a cambiar su lugar de residencia.

Igualmente, el director de la pastoral social, entidad de caridad de la iglesia católica en el Distrito Especial de Buenaventura, indica cómo dentro de su función social, ha vivido y ha tenido conocimiento de la violencia generada por los dos grupos criminales en disputa y además ha atendido a la población desplazada, muchas veces colaborándoles con refugio o con atenciones básicas como alimentación.

Se cuenta con el relato de las víctimas, quienes indican que cambiaron su lugar de residencia ante la violencia generada por las organizaciones criminales La Empresa y Los Urabeños.

De estos elementos se puede concluir, que es la violencia, el actuar de toda la estructura criminal y los actos de violencia que la caracterizaban, lo que ocasionó los desplazamientos de la población de los diferentes barrios y comunas de Buenaventura, siendo el principal acto de violencia la presencia armada ilegal que las organizaciones realizaban allí.

Así entonces, puede decirse que al concertarse los acusados para cometer delitos, al hacer presencia armada en los diferentes barrios y comunas de Buenaventura y además cumplir un rol dentro de la organización criminal que permitió sostener ese panorama de violencia, son coautores de generar las condiciones que provocaron los desplazamientos forzados de la población de Buenaventura.

Es claro, que un sector de la población tan amplio, como un barrio o una comuna, no se dejaría amedrentar de un solo individuo, pues socialmente hubiesen buscado la forma de neutralizar los ataques, pero ante unas estructuras criminales, con una cantidad considerable de miembros, recursos bélicos $\mathrm{y}$ acciones violentas materializadas, como los homicidios y desmembramiento de personas, las balaceras o confrontaciones armadas y la misma presencia armada, la única alternativa que pueden observar los pobladores, es huir para salir de la zona de riesgo.

Es por ello, que cada uno de los acusados, mediando un acuerdo común y una división de trabajo, contribuyó a sostener la política violenta dirigida contra la población por parte de las 
organizaciones criminales y ocasionaron que miembros de ésta cambiaran su lugar de residencia.

Esta tesis encuentra sustento en lo dicho por la Sala de Casación Penal, en sentencia SP 3742-2014, proferida dentro del radicado 38795, Magistrado Ponente José Luis Barceló Camacho:

"la experiencia enseña que la sola presencia y establecimiento de uno u otro grupo armado ilegal en una región donde ejerce influencia es suficiente para ocasionar en los habitantes un justificado temor por su integridad y, por tanto, idóneo para mover a los pobladores a abandonar el lugar, sin esperar a que se produzcan consecuencias fatales."

Así entonces, si la población se vio obligada a movilizarse por la violencia generada por las organizaciones criminales, son los miembros de las mismas los responsables de estos desplazamientos, que es lo que pretende este delegado demostrar a través del trámite de este proceso, que son los acusados como miembros de las organizaciones criminales "La Empresa" y "Los Urabeños" posteriormente autodenominados "Gaitanistas", que al adscribirse al plan criminal de las organizaciones, al compartir sus métodos delictivos y al participar activamente en ellos, promovieron los actos de violencia y en sí todo el panorama de violencia que ocasionó los desplazamientos de los pobladores de los diferentes barrios y comunas de Buenaventura, Valle del Cauca durante los años 2012, 2013 y 2014.

Esta tesis, también se sustenta en lo expresado por la Sala de Casación Penal de la Corte Suprema de Justicia dentro de la sentencia ya citada y que indica:

"La descripción típica de la conducta le permite a la Corte precisar, como así mismo lo hace la Procuradora Tercera Delegada para la Casación Penal en su concepto, que el desplazamiento forzado es un delito permanente, pues pone a las víctimas en condición de desarraigados, y se sigue cometiendo mientras esa condición se perpetúe en virtud a que la conducta del sujeto activo mantenga vigentes los factores de amenazas, miedo, muertes o atentados vinculados con el conflicto que obligan a los habitantes de un específico grupo humano a estar alejados de sus predios. De allí que cualquier acción que actualice tales temores, originada en el obrar voluntario de un sujeto concertado con el actor armado del conflicto que ha generado el desplazamiento, se 
subsume en el tipo penal en comento.”

Igualmente en sentencia SP8753-2016 de fecha 29 de junio de 2016, emitida dentro del radicado 39290, magistrado ponente José Francisco Acuña Vizcaya, la Sala de Casación Penal de la Corte Suprema de Justicia mantiene este criterio, dejando por sentado que normalmente el delito de desplazamiento forzado se configura en contextos de macro-criminalidad desarrollados por un agente plural como lo son las organizaciones criminales.

En este caso, se tiene conocimiento, que producto del contexto de macro-criminalidad desarrollado por las organizaciones criminales que delinquieron en Buenaventura entre el año 2012 y el año 2014 y que se produjo en razón a la participación de los acusados, aproximadamente 9052 familias se desplazaron de las diferentes comunas y barrios de Buenaventura, 1425 durante el año 2012, 3441 familias durante el año 2013 y 4186 familias durante el año 2014. Muchas de las familias se trasladaron con cada uno de sus miembros, en los que se incluían niños y ancianos, personas estas que gozan de una especial protección constitucional.

El desplazamiento forzado, afectó las 12 comunas que conforman la zona urbana del Distrito Especial de Buenaventura, como lo evidencian los cuadros que a continuación se muestran:

\begin{tabular}{|c|c|}
\hline & AÑO 2012 \\
\hline Comuna & Cantidad de familias desplazadas \\
\hline & 65 \\
\hline 1 & 12 \\
\hline 10 & 81 \\
\hline 11 & 68 \\
\hline 2 & 394 \\
\hline 3 & 37 \\
\hline 4 & 72 \\
\hline 5 & 55 \\
\hline 6 & 134 \\
\hline 8 & 33 \\
\hline 9 & 241 \\
\hline Total general & 93 \\
\hline \multicolumn{2}{|c|}{} \\
\hline Comuna & 140 \\
\hline \multicolumn{2}{|c|}{} \\
\hline \multicolumn{2}{|c|}{} \\
\hline
\end{tabular}




\begin{tabular}{|c|c|}
\hline 1 & 49 \\
\hline 10 & 218 \\
\hline 11 & 189 \\
\hline 12 & 883 \\
\hline 2 & 364 \\
\hline 4 & 421 \\
\hline 5 & 544 \\
\hline 6 & 192 \\
\hline 7 & 46 \\
\hline 8 & 127 \\
\hline 9 & 83 \\
\hline Total general & 104 \\
\hline & 3441 \\
\hline & \\
\hline Comuna & Cantidad de familias desplazadas \\
\hline & 251 \\
\hline 1 & 914 \\
\hline 10 & 265 \\
\hline 11 & 281 \\
\hline 12 & 965 \\
\hline 3 & 468 \\
\hline 4 & 433 \\
\hline 5 & 723 \\
\hline 6 & 191 \\
\hline 8 & 77 \\
\hline Total general & 190 \\
\hline & 130 \\
\hline & 121 \\
\hline & 4186 \\
\hline
\end{tabular}

\section{Acusación jurídica}

Este delegado del Fiscal General de la Nación, considera que los hechos objeto de esta acusación y por los que se acusa a las personas relacionadas, se adecuan a lo establecido en el Código Penal Colombiano (ley 599 de 2000), libro segundo de los delitos en particular, Titulo III Delitos contra la libertad individual y otras garantías, Capitulo Quinto De los delitos contra la autonomía personal, artículo 180 Desplazamiento forzado y que a la letra indica:

"El que de manera arbitraria, mediante violencia u otros actos coactivos dirigidos contra un sector de la población, ocasione que uno o varios de sus miembros cambien el lugar de residencia, incurrirá en prisión de noventa y seis (96) meses a doscientos dieciséis (216) meses y multa de ochocientos (800) a dos mil doscientos cincuenta (2.250) 
salarios mínimos legales mensuales vigentes y en interdicción de derechos y funciones públicas de noventa y seis (96) meses a doscientos dieciséis (216) meses”

Como se evidencia, la conducta penalizada se configura con el cambio de residencia de uno o varios de los miembros del sector de la población, contra el cual se realizaron actos de violencia, en este caso más de 9000 familias cambiaron su lugar de residencia, motivados por los actos de violencia realizados por los acusados.

Muchas de las familias se trasladaron con cada uno de sus miembros, en los que se incluían niños y ancianos, por lo que se configura dentro de la conducta el agravante establecido en el numeral 2, del artículo 181 del Código Penal, y que indica:

ARTICULO 181. CIRCUNSTANCIAS DE AGRAVACION PUNITIVA. La pena prevista en el artículo anterior se aumentará hasta en una tercera parte:

$(1 \ldots)$

2. Cuando se cometa en persona discapacitada, o en menor de dieciocho (18) años, o mayor de sesenta (60) o mujer embarazada.

Igualmente, se configuran en los hechos las circunstancias de mayor punibilidad establecidas en el numeral 7 y 10 del artículo 58 del Código Penal y que indican:

(...) 7. Ejecutar la conducta punible con quebrantamiento de los deberes que las relaciones sociales o de parentesco impongan al sentenciado respecto de la víctima. (...)

(...)10. Obrar en coparticipación criminal. (...)

Acusación jurídica concierto para delinquir

De acuerdo a los hechos relacionados en el acápite de acusación fáctica, se les acusa del delito establecido en el Código Penal Colombiano (ley 599 de 2000), libro segundo de los delitos en particular, título XII delitos contra la seguridad pública, capítulo primero del Concierto, el terrorismo, las amenazas y la instigación, artículo 340 del Concierto para delinquir agravado de 
acuerdo al inciso 2 y que establece:

Cuando varias personas se concierten con el fin de cometer delitos, cada una de ellas será penada, por esa sola conducta, con prisión de cuarenta y ocho (48) a ciento ocho (108) meses.

INC. 2. Cuando el concierto sea para cometer delitos de genocidio, desaparición forzada de personas, tortura, desplazamiento forzado, homicidio, terrorismo, tráfico de drogas tóxicas, estupefacientes o sustancias sicotrópicas, secuestro, secuestro extorsivo, extorsión, enriquecimiento ilícito, lavado de activos o testaferrato y conexos, o Financiamiento del Terrorismo y administración de recursos relacionados con actividades terroristas, la pena será de prisión de ocho (8) a dieciocho (18) años y multa de dos mil setecientos (2700) hasta treinta mil (30000) salarios mínimos legales mensuales vigentes.

\subsection{Bienes Vinculados SI_xx__ NO}

Descripción y situación jurídica (Clase de bien, autoridad que incauto, fines de la incautación, fecha y juez ante quien se legalizó la incautación).

\section{Datos del Fiscal:}

\begin{tabular}{|c|c|c|c|c|c|}
\hline Nombres y apellidos & \multicolumn{5}{c|}{ JAROL ESTIBENS ECHEVERRY GIRALDO } \\
\hline Dirección: & \multicolumn{3}{|c|}{ Edificio Saavedra Oficina 304 } & Oficina: & 304 \\
\hline Departamento: & VALLE DEL CAUCA & Municipio: & Buga \\
\hline Teléfono: & 3184041708 & Correo electrónico: & Jarol.echeverry@ fiscalia.gov.co \\
\hline Unidad & \multicolumn{3}{|c|}{ SUBDIRECCIÓN SECCIONAL DE FISCALIAS } & No. de Fiscalía 33 Local \\
\hline
\end{tabular}

Firma,

JAROL ESTIBENS ECHEVERRY GIRALDO

FISCAL 33 LOCAL 


\section{Preguntas de las entrevistas}

1. ¿En qué consiste el nuevo sistema de investigación judicial penal de análisis de contexto y por qué considera usted relevante implementar, esta nueva estrategia de investigación dentro del marco del derecho penal?

2. ¿En qué consiste la técnica de priorización de situaciones y casos que realiza la Fiscalía General de la Nación y cómo se lleva a cabo dicha investigación, para el caso de las situaciones de alto impacto en Colombia?

3. ¿Cuáles serían en su concepto, los avances más significativos de la nueva metodología de investigación de análisis de contexto, tomando como base los criterios de priorización de situaciones y casos?

4. ¿En sus propias palabras, explique qué es el desplazamiento forzado por la violencia y cómo ha sido el proceso de investigación para este delito, por medio de esta nueva estrategia de investigación penal?

5. ¿Considera usted que es útil esta nueva estrategia de investigación por medio de la creación de contextos, en relación con el delito de desplazamiento forzado por la violencia? si, no y porqué, explique su respuesta.

6. Explique cómo se lleva a la práctica, el proceso de investigación por medio de la construcción de contextos, para el delito de desplazamiento forzado en particular.

7. ¿Cuáles son, porqué y para qué son útiles dentro de la investigación penal, los criterios de priorización de situaciones y casos, que han sido implementados por parte de la Fiscalía General de la Nación?

8. ¿Usted considera que dichos criterios de priorización, han sido útiles y aplicables para el delito de desplazamiento forzado por la violencia?

9. ¿Qué resultados hasta el momento, se han obtenido a favor de las víctimas de éste delito, por medio de ésta nueva estrategia de investigación penal?

10. ¿Desde su punto de vista y como funcionario de la DINAC, a través de la utilización de la estrategia de investigación de análisis de contexto, han sido una realidad los derechos de las víctimas dentro del contexto del conflicto armado interno?

11. ¿En su concepto, se debería implementar de igual manera, la estrategia de investigación del análisis de contexto dentro de la Justicia Penal Ordinaria? 
12. ¿En el caso de que sea viable implementar la creación de contextos en la Justicia Penal Ordinaria, en cuáles delitos considera usted que sería aplicable dicha estrategia de investigación específicamente?

\section{Respuestas a las entrevistas}

\section{Dirección de Análisis y contextos \\ Fiscalía General de la Nación. \\ Trabajo de investigación}

Fecha: 12 de octubre de 2016

\section{Nombres y apellidos completos: Dra. Mónica María Suarez Moscoso Cargo desempeñado en la DINAC: Fiscal 13 especializado}

1. Para contestar esta pregunta se deben tener en cuenta, los antecedentes de la Ley de Justicia y Paz, dentro de un contexto de violación de los derechos humanos. La Directiva 001 de 2012 de la Fiscalía General de la Nación, debía trabajarse para el proceso penal y analizar la forma en la cual, debía entenderse el contexto, es decir, como prueba o un como criterio orientador.

Durante los años 2012 y 2013, se estudió por parte de la Dirección Nacional de Análisis y Contexto (DINAC), la manera como se presentaban las investigaciones en contexto para los casos penales. Por medio de la metodología de la Investigación en Contexto, se buscó priorizar Urabá y Montes de María, por ser zonas de consolidación geográfica, y donde se podría analizar más concretamente la situación de las víctimas de delitos de alto impacto, en particular la situación de periodistas, dirigentes de la UP, sindicatos, y líderes sindicalistas, entre otros.

En lo que respecta a la guerrilla de las FARC, se buscó priorizar reclutamiento forzado y violencia sexual, y durante el mes de marzo del año 2014 se priorizaron algunos delitos de la guerrilla de las FARC, tales como, las ejecuciones arbitrarias o extrajudiciales, y los 
magnicidios de Luis Carlos Galán Sarmiento, Bernardo Jaramillo, Carlos Pizarro, Antequera, Rodrigo Lara Bonilla, los escoltas del DAS, entre otros.

En la seccional Antioquia del Departamento Administrativo de Seguridad (DAS), las investigaciones se desvían y en lo concerniente a las investigaciones sobre violaciones a Derechos Humanos, el Estado responde tanto por acción como por omisión.

Se determina una metodología de priorización, lo que busca es hacer informes, donde se construirán situaciones que permitieran seleccionar casos, y posteriormente hacer la investigación en contexto, es decir, que la situación se presenta y posteriormente se construye el contexto

Como ejemplo, de lo anterior, tenemos el grupo armado del ELN y algunos delitos tales como, los homicidios de mujeres, el desplazamiento forzado de mujeres, las desapariciones forzadas de mujeres, donde se buscó analizar, qué móvil une esos tres hechos que puede ser por relaciones personales o laborales con la Fuerza Pública.

El enemigo natural del grupo ilegal del ELN, es la Fuerza Pública. Se priorizo también Arauca, Boyacá y Casanare, y el Frente de Guerra Oriental y se definía su estructura, posteriormente, se analizaba la situación, que en estos casos es de la violencia basada en género, la hago y la investigo con un fiscal investigador, quien establece la participación y los presuntos responsables.

Posteriormente en la Directiva 002 de 2012, de la Fiscalía General de la Nación, se incluye el criterio de priorización de carga laboral, es decir, se realiza la priorización, por medio de los criterios objetivo, subjetivo, complementario y de carga laboral. La Dirección de Análisis y Contextos de la Fiscalía General de la Nación, construye la situación por medio de las denuncias, con el apoyo de las inspecciones judiciales, por medio de la revisión de carpetas, y de la revisión de los expedientes. 
De lo anterior, surge un informe de contexto, y al llegar al Comité de Priorización, se asignan los casos a un determinado Fiscal.

Esta nueva metodología de investigación, es considerada de vital importancia, porque es una forma de investigar diferente que contribuye para ir definiendo la hipótesis de investigación que se ha planteado dentro del programa metodológico.

2. Existen dos niveles de priorización que son el nacional y el seccional. Se realizan unos comités a principio de año y los directores de los mismos, determinan que casos y qué situaciones van a priorización, presentan los casos al Comité con observaciones o avalan el plan de acción del año correspondiente.

Se priorizan las situaciones de alto impacto y cada Director Nacional, escoge los criterios de priorización, al crear una situación para aplicarla y se le da la connotación.

Se establece un acercamiento para mirar la noticia criminal y analizar qué se debe presentar al Comité, posteriormente, se explica el fenómeno delictual, el cual, es un contexto. Se explica el fenómeno delictual, el cual, ya es un contexto, es decir, se explica el fenómeno, se prioriza la situación con un caso emblemático o con varios casos, es decir, existe una asociación de casos, los cuales están unidos por medio de una línea de tiempo, se determina la estructura de la organización criminal, y se lleva el caso y se presenta para que el proceso de investigación sea más efectivo.

3. Por medio de esta estrategia de investigación, se logra determinar y a la vez analizar, el modus operandi de una organización criminal, la estructura de un grupo o de una pandilla. Esta estrategia es utilizada, para desmantelar el crimen organizado, y por medio de ella establecer la estructura (a nivel orgánico y a nivel funcional), es decir, la línea de mando. 
Además por medio de ella, se logra presentar un informe que permite conocer la organización criminal en toda su dimensión, y se logra determinar cómo es dicha estructura, su historia y la construcción con fuentes procesales.

4. Se revisan las carpetas con las noticias criminales que llegan a la Dirección de Análisis y Contextos, y se crea una matriz en Excel y se sacan 10 variables que pueden ser entre otras, la siguientes: nombres y apellidos de la víctima, fecha del desplazamiento, numero del proceso, grupo armado al margen de la ley que lo cometió, en qué etapa está el proceso, si el proceso está activo inactivo, un posible modus operandi, el sistema procesal vigente, es decir, si el caso se rige por la ley 906 o por la ley 600, el lugar de los hechos, fecha de los hechos, línea de tiempo por año o por meses, y como ya lo mencioné, la ley aplicable a dicha situación.

Por medio de la actividad anterior, se reduce el nivel de carga laboral dentro del proceso de priorización, y de acuerdo a las variables, se asocian los casos y se construyen las situaciones del delito de desplazamiento forzado.

A medida que traen la información, en el mismo momento la van analizando, y el documento final, el cual incluye diferentes criterios de priorización, sería un informe de contexto. Se debe tener en cuenta, que el delito de desplazamiento forzado, puede ser rural, urbano, intraurbano, de conformidad con situación que se pretenda categorizar.

Se debe mirar el contexto del delito de desplazamiento forzado y el contexto de la violencia que se está viviendo en la zona de conflicto, y de esta manera se logra definir el fenómeno delictual.

5. Considero que esta estrategia de investigación es útil, porque determina el fenómeno de la violencia, que se está viviendo y se busca la adecuación típica que corresponda a la conducta.

6. La metodología te la expliqué en la pregunta número cuatro. 
7. Los criterios de priorización son los objetivos, los subjetivos, los complementarios y los de carga laboral. Por medio de dichos criterios, se logra definir cualquier caso emblemático o una situación en particular.

8. Considero que se debe a que se logran definir una situación aplicando cualquiera de los mismos criterios.

9. No existen estadísticas actuales, hasta el momento la única sería la situación del Fondo Ganadero de Córdoba.

10. No son propiamente los fines de la Justicia Transicional, son los derechos de las víctimas consagrados en la ley 975 de 2005, y considero que sí, debido a que los casos de la Unión Patriótica que fueron trabajados en contexto, ayudan a descubrir la verdad sobre lo que pasó, con el objetivo de que tales hechos no vuelvan a suceder desde el marco del Acuerdo de Paz. También se estudian las situaciones de los magnicidios, con el fin de descubrir la verdad, y todo esto se analiza de mejor manera en las sentencias C - 228 de 2002, C - 209 de 2007, C- 454 de 2006 y C - 516 de 2007.

11. Dentro del proceso penal, por vía de bloque de constitucionalidad los derechos de las víctimas son la verdad, la justicia, la reparación integral y la garantía de no repetición de crímenes atroces.

12. Considero que si, por medio del estudio de las Directivas 001 y 002 de 2012 y de las Resoluciones de la Fiscalía General de la Nación.

13. Considero que en todos debería aplicarse, pero por citar algunos ejemplos, tenemos el delito de la violencia intrafamiliar, en la cual, se asocian los casos, se traen a la Dirección de Análisis y Contextos, se analizan y se crea una situación, o por ejemplo, un caso donde una mujer, ha sido víctima de maltrato en reiteradas ocasiones, es decir, en el delito de feminicidio y allí existe el contexto. 
También se puede aplicar, en el caso de los fleteros que cometen delitos contra el Patrimonio Económico, en el Hurto de Vehículos, y en los Homicidios, ya que en todos estos casos, se focaliza la investigación en ciertas partes y se construyen los informes y existe un análisis de toda la información.

Finalmente, por medio de la investigación en contexto, existe una metodología interna, la cual, se basa en el inventario de los procesos que llegan a la Dirección.

Muchas gracias 


\section{Dirección de Políticas Públicas}

Fiscalía General de la Nación.

Fecha: 16 de marzo de 2017

\section{Nombres y apellidos completos: Dra. Gina Cabarcas Maciá}

\section{Cargo desempeñado en la Fiscalía general de la nación: Directora Nacional de Políticas \\ Públicas}

\section{Respuestas}

1. El análisis de contexto, busca contextualizar el hecho que se investiga, determinar su impacto a nivel nacional e internacional, e identificar a los autores materiales y los autores intelectuales de los hechos perpetrados.

2. Las Directivas de priorización son la 001 de 2012 y 002 de 2015, que presentan la metodología del análisis de contexto, con base en los criterios de priorización, tales como, el objetivo, el cual, determina la gravedad y la importancia de los casos, el subjetivo, que establece las calidades de las víctimas y la calidad del perpetrador o de los perpetradores, y el complementario, que determina la dificultad del análisis del caso, teniendo en cuenta si las pruebas allegadas son suficientes, la forma en la cual, se consiguieron esas pruebas y la carga de trabajo.

3. Los avances de la política de priorización y del contexto, la metodología de investigación de los casos y los criterios de priorización, se han socializado, con el objetivo de aumentar las tasas de imputación de los delitos priorizados.

4. Casi no se ha aplicado esa política en el delito de desplazamiento forzado por su misma dificultad, solamente se ha aplicado en algunos pocos casos en el desplazamiento y en el delito de despojo de tierras en el Urabá desde el año de 1997, y se logró imputar responsabilidad penal al Fondo Ganadero de Córdoba. 
También, en el caso del desplazamiento intraurbano en Buenaventura entre los años 2002 - 2014, y se logró imputar responsabilidad penal a cincuenta miembros del grupo de la Empresa, por medio del desplazamiento de las familias de esa zona.

En el Urabá en el año de 1994, se imputó responsabilidad penal a los autores intelectuales beneficiados de los falsos positivos. Por medio de la investigación en contexto, se logró determinar además, la corrupción de la Contratación Estatal y el análisis de contexto ayudó a imputar responsabilidad penal, con ayuda de pruebas directas, ya que el contexto es una guía de la investigación y no es utilizado como prueba dentro del proceso, y se llevó a juicio peritajes y disciplinas específicas, para poder explicar el caso.

En el caso del Urabá, se utilizaron a dos analistas para explicar los elementos del contexto.

En el caso de Buenaventura, por medio del desplazamiento de varias familias durante los años 2012 a 2014, se utilizó el contexto como guía de la investigación, y en Registro Único de Victimas (URV), dentro del mismo caso, se reconstruyó el contexto y se imputó responsabilidad penal a cincuenta personas del grupo criminal de "La Empresa".

5. Es útil esta estrategia de investigación, pues el desplazamiento forzado supone entender el contexto de violencia y tiene dificultades, y al mismo tiempo no es suficiente como herramienta que ayude a esa imputación.

6. La política de priorización, busca diseñar políticas públicas, ya que los criterios miran el orden y los recursos de los casos. Se busca llevar la prueba al juicio, y en las etapas de indagación e investigación, se buscan hallar elementos materiales probatorios, para poder enrrutar la investigación, y ayudar a construir el proceso metodológico.

7. Son útiles para tomar decisiones en relación con la carga de trabajo y para darles los recursos a unos casos más que a otros. La priorización no es la selección de casos, es una 
forma de organizar el trabajo de los fiscales, para que no sólo se investiguen los casos fáciles.

8. Si es una herramienta de investigación útil para ese y para otros delitos que atenten contra el derecho internacional humanitario.

9. Dentro de la política de priorización hay pocos ejemplos, y la misma sirve pero no se ha aplicado a profundidad.

10. No conozco en relación con la Justicia Transicional, pero debería revisar las sentencias del Tribunal de Justicia y Paz, en el tema del delito de desplazamiento forzado.

11. Si, se debe aplicar, ya que todo es en la Justicia Penal Ordinaria.

12. Se debe aplicar en todos los delitos, y en los delitos que atenten contra el Derecho Internacional Humanitario también.

Podría analizar el caso de Benito Osorio en Sentencia anticipada.

Muchas gracias 


\section{Corte Constitucional}

Trabajo de investigación

Fecha: 03 de abril de 2017

\section{Nombres y apellidos completos: Dr. Alejandro Ramelli Arteaga \\ Cargo desempeñado en la corte constitucional: Magistrado auxiliar}

\section{Respuestas}

1. La investigación de análisis de contexto, consiste en investigar con técnicas tradicionales forenses e investigativas, con aportes de las ciencias sociales aplicadas, tales como, la economía, la politología, la sociología entre otras, con el fin de reagrupar casos y encontrar patrones criminales e investigar crímenes de sistema.

2. La priorización técnica que organiza de forma racional las investigaciones, de acuerdo a los criterios, busca reagrupar varios casos con iguales patrones criminales y la misma organización, red o estructura armada.

3. El Informe de Gestión del doctor Alejandro Ramelli del año 2013, y el informe de rendición de cuentas hasta el año 2013, donde se presentan los criterios, avances y capacitación en dicha metodología de investigación.

4. Se busca reagrupar, por situaciones con variables temporales, y espaciales, como ejemplo, tenemos los casos de Curbaradó y Jiguamiandó, que se encuentran en la Unidad de Atención al Desplazado de la Fiscalía General de la Nación. Donde se toman múltiples casos y los investigan como un todo por operación, se reagrupa y se delimita la situación y se investigan conjuntamente.

5. Sí, debido a que se comete un delito y responde a una estrategia criminal para apropiarse de tales regiones, de los monocultivos, y se realiza la ejecución de planes para apropiarse de determinada región, teniendo en cuenta, que no son hechos fortuitos, ni aislados, y lo 
sujetos activos desplazan y compran tierras, por medio de la coacción para apropiarse de esas mismas tierras.

6. Es un crimen a gran escala, se hace trabajo al verificar las fuentes de información de la Fiscalía, que proviene de los departamentos que acumulan casos, actores armados, etc... Al identificar gráficamente los expedientes, se investigan en conjunto, para hallar a los máximos responsables.

7. Para ello es conveniente revisar la cartilla de Priorización de la Fiscalía General de la Nación, donde se encuentran las memorias de los talleres, y se explica de dónde surgen y para qué son útiles los criterios de priorización. El objetivo, mira la gravedad y la intensidad de las conductas y la estructura de la organización criminal como tal, el subjetivo analiza las víctimas y los victimarios y finalmente el complementario, analiza el delito a nivel regional y desde el sistema interamericano, y para investigar estos crímenes, se toman en cuenta, los tres criterios.

8. Sí, porque se investigaba anteriormente sin orden y sin ningún estrategia. Antes, los expedientes que llegaban se arrojaban en esa unidad, y se investigaban caso por caso, y ahora se procede a reagruparlos y entenderlos como un todo.

9. Estos resultados los manejan en la Unidad de Desplazamiento de la Fiscalía General de la Nación, donde se reagrupan los casos, de acuerdo a una estrategia criminal.

10. Considero que sí, porque el derecho a la verdad se garantiza de mejor manera, y las estrategias detrás de su victimización se manejan, por medio de un gran plan, con propósitos específicos, y existe una visión mucho más clara, para su investigación.

11. Sí, para temas de corrupción y se investiga caso a caso con redes transicionales, y en delitos tales como el narcotráfico, con grandes redes criminales, el contrabando, etc... 
12. En delitos selectivos, donde la víctima, se escoge por la actividad que ejerce en determinado momento, tales como periodistas, y en los procesos de restitución de tierras despojadas.

Muchas gracias

3.Colombia, Congreso Nacional de la República, (2012, 31 de julio), "Acto Legislativo No. 1 del 31 de julio de 2012, por medio del cual se establecen instrumentos jurídicos para de justicia transicional en el marco del artículo 22 de la Constitución Política y se dictan otras disposiciones”, en Diario Oficial, núm. 48.508, 31 de julio de 2012, Bogotá, D.C.

4. Colombia, Congreso Nacional de la Republica (2013, 3 de diciembre), "Ley 1592 del 3 de diciembre de 2012,por medio de la cual se introducen modificaciones a la Ley 975de 2005 por la cual se dictan disposiciones para la reincorporación de miembros de grupos armados organizados al margen de la ley, que contribuyan de manera efectiva a la consecución de la paz nacional y se dictan otras disposiciones para acuerdos humanitarios y se dictan otras disposiciones”, en Diario Oficial, núm. 48.633, 3 de diciembre de 2012, Bogotá, D.C.

5. Colombia, Congreso Nacional de la Republica (2013, 15 de julio), "Ley 1654 del 15 de julio de 2013, por la cual se otorgan facultades extraordinarias pro tempore al Presidente de la República para modificar la estructura y la planta de personal de la Fiscalía General de la Nación y expedir su Régimen de Carrera y situaciones administrativas", en Diario Oficial, núm.48.852, 15 de julio de 2013, Bogotá, D.C.

6. Colombia, Corte Constitucional, (2013, 28 de agosto), "Sentencia C - 579", M.S. Pretelt Chaljub, J.I., Bogotá, D.C.

7. Colombia, Corte Constitucional, (2014, 6 de agosto), "Sentencia C - 577”, M.P. Sáchica Méndez, M.V., Bogotá, D.C. 
8. Colombia, Departamento Administrativo de la Función Pública (2014, 9 de enero), "Decreto número 016 del 9 de enero de 2014, por el cual se modifica y define la estructura orgánica y funcional de la Fiscalía General de la Nación”, en Diario Oficial, núm. 49.028, 9 de enero de 2014, Bogotá, D.C.

9. Colombia, Fiscalía General de la Nación (2012, 4 de octubre), "Directiva No. 0001 del 4 de octubre de 2012, por medio de la cual se adoptan unos criterios de priorización de situaciones y casos, y se crea un nuevo sistema de investigación penal y de gestión de aquéllos en la Fiscalía General de la Nación”, 4 de octubre de 2012, Bogotá D.C.

10. Colombia, Fiscalía General de la Nación (2015, 9 de diciembre), "Directiva No. 0002 del 9 de diciembre de 2015, por medio de la cual se amplía y se modifica la Directiva 01 de 2012, se desarrolla el alcance de los criterios de priorización de situaciones y casos, y se establecen lineamientos para la planificación y gestión estratégica de la investigación penal en la Fiscalía General de la Nación”, 9 de diciembre de 29015, Bogotá, D.C.

11. Colombia, Fiscalía General de la Nación (2014, 30 de julio), "Resolución No. 01343 del 30 de julio de 2014, por medio de la cual se reglamentan el Comité Nacional y los Comités Seccionales de Priorización de Situaciones y Casos, y se asignan diversas funciones para la implementación de la política de priorización”, 30 de julio de 2014, Bogotá D.C. 